\title{
Revelation, Religion, and Culture in Kwame Bediako and Karl Barth
}

\author{
Timothy M. Hartman \\ Charlottesville, Virginia \\ Bachelor's of Arts, Stanford University, 1995 \\ Master's of Divinity, Princeton Theological Seminary, 2000 \\ Master's of Arts, University of Virginia, 2012 \\ A Dissertation presented to the Graduate Faculty \\ of the University of Virginia in Candidacy for the Degree of \\ Doctor of Philosophy \\ Department of Religious Studies \\ University of Virginia \\ May 2014 \\ (C) Timothy M. Hartman
}




\section{Table of Contents}

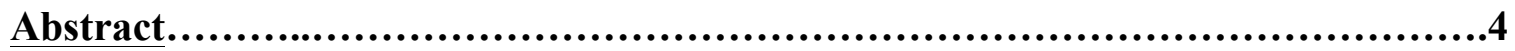

Abbreviations...........................................................................

Preface...............................................................................6

\section{Chapter 1:}

Bediako, Barth, and Theology in the Twentieth Century..............................9

I. Bediako: An African in Europe and the World

II. Barth: A European in Switzerland and Germany

III. Shared Inheritances

A. Ancients and Moderns

B. The Blumhardts

IV. Mutual Suspicion

V. Three Themes: Revelation, Religion, and Culture

VI. The Shape of the Argument

\section{Chapter 2:}

Kwame Bediako: An Act of Theological Négritude

I. Questions of Identity

A. French theses

i. Négritude et Surréalisme

ii. L'Univers Interieur de Tchicaya U Tam'si

B. Towards an African Christian Identity

C. "Relevance without Syncretism"

D. History: Twin Heritage of African Christianity

II. Revelation, Religion, and Culture

A. Revelation: Infinite Translatability of the gospel

B. Religion: Continuity of Christianity with African Traditional Religion

C. Culture:

i. Indigeneity of Christianity in Africa

ii. Primal Imagination as the Substructure of African Christianity

III. A Theology of Ancestors: Interrelationship of Revelation, Religion, and Culture

IV. Constructive Questions

A. Religious Pluralism

B. Re-making a non-Western religion

C. World Christianity(-ies) 


\section{Chapter 3:}

Karl Barth: The Ongoing Prophetic Activity of Jesus Christ.

I. The Prophetic Office of Jesus Christ

A. Church Dogmatics IV.3, §69

B. Prophecy, History, and Narrative

II. Revelation

A. All Revelation is Self-Revelation: Imagery of Light

B. Revelation is for all people: History/Worldview

C. Revelation is ongoing

III. Culture

A. Parables of the Kingdom

B. "Secular" and "Periphery"

IV. Religion

A. Revelation vs. Projection

B. Person vs. Principle: Reading I.2, §17 in light of IV.3, §69

V. Implications

\section{Chapter 4:}

Two Christocentric Theologies

I. The Universality of Christ

A. Bediako: Universality through Christ's Divinity

B. Barth: Universality through Christ's Resurrection

II. Reading the Epistle to the Hebrews Theologically

A. Barth's Dogmatic Reading

B. Bediako's Cultural Reading

C. Hebrews and Revelation

III. Encounters between Gospel and Culture

A. Revelation: Translatability and Light

B. Religion: An Unexpected Convergence

C. Culture: Differing Universalisms

IV. Are we all syncretists?

\section{Chapter 5:}

Conclusion.

\section{Appendix}

Complete Writings of Kwame Bediako in Chronological Order 


\title{
Revelation, Religion, and Culture in Kwame Bediako and Karl Barth
}

\author{
Abstract \\ In this dissertation, I analyze the comprehensive work of Ghanaian \\ theologian Kwame Bediako (1945-2008) and place the themes that arise- \\ revelation, religion, and culture - in constructive dialogue with the mature \\ Christology of Swiss-German theologian Karl Barth (1886-1968) in his \\ Church Dogmatics IV.3, §69. In doing so, the dissertation performs its \\ major claim: I argue for the necessity of cross-cultural theological \\ comparisons to navigate contemporary theological and religious questions, \\ including the complex nature of Christianity in the world today.
}




\section{ABBREVIATIONS}

\section{Works by Kwame Bediako}

CiA Christianity in Africa: The Renewal of a non-Western Religion

(Edinburgh: Edinburgh University Press, 1995).

CFAC "Christian faith and African Culture-An Exposition of the Epistle to the Hebrews" Journal of African Christian Thought 13.1 (2010), 45-57.

Ebenezer with Gillian Mary Bediako, "Ebenezer, this is how far the Lord has helped us': Reflections on the Institutional Itinerary of the AkrofiChristaller Memorial Centre for Mission Research \& Applied Theology (1974-2005)," unpublished (May 2005).

JAC "Jesus in African Culture: A Ghanaian Perspective" in Jesus and the Gospel in Africa (Oxford: Regnum, 2000).

JACT Journal of African Christian Thought, published by the Akrofi-Christaller Institute for Theology, Mission, and Culture in Akropong-Akuapem, Ghana, 1998-present

NS Négritude et Surréalisme: Essai sur l'oeuvre poétique de Tchicaya U Tam 'si, unpublished master's thesis, Université Bordeaux III

TI Theology and Identity: the impact of culture on Christian thought in the second century and modern Africa (Oxford: Regnum, 1993).

UI Lnivers Interieur de Tchicaya U Tam'si, unpublished doctoral thesis, Université Bordeaux III

\section{Works by Karl Barth}

I. 1

I. 2

II.1

II. 2

III. 1

III. 2

III.3

III.4

IV.1

IV.2

IV.3

IV.4

TCL
Church Dogmatics, vol. I, part 1 (Edinburgh: T\&T Clark, $2^{\text {nd }}$ ed., 1975)

Church Dogmatics, vol. I, part 2 (Edinburgh: T\&T Clark, 1956)

Church Dogmatics, vol. II, part 1 (Edinburgh: T\&T Clark, 1957)

Church Dogmatics, vol. II, part 2 (Edinburgh: T\&T Clark, 1957)

Church Dogmatics, vol. III, part 1 (Edinburgh: T\&T Clark, 1958)

Church Dogmatics, vol. III, part 2 (Edinburgh: T\&T Clark, 1960)

Church Dogmatics, vol. III, part 3 (Edinburgh: T\&T Clark, 1960)

Church Dogmatics, vol. III, part 4 (Edinburgh: T\&T Clark, 1961)

Church Dogmatics, vol. IV, part 1 (Edinburgh: T\&T Clark, 1956)

Church Dogmatics, vol. IV, part 2 (Edinburgh: T\&T Clark, 1958)

Church Dogmatics, vol. IV, part 3 (Edinburgh: T\&T Clark, 1961)

Church Dogmatics, vol. IV, part 4 (Edinburgh: T\&T Clark, 1969)

The Christian Life: Church Dogmatics IV.4, Lecture Fragments, ed. HansAnton Drewes and Eberhard Jüngel; trans. Geoffrey Bromiley (London: T\&T Clark, 2004). 


\section{PREFACE}

I have come to this project out of my pastoral experiences in Los Angeles and Baltimore. In Los Angeles, I lived near the corner of Little Armenia and Thai town in a neighborhood with no ethnic majority. I saw churches wrestling with rapidly increasing ethnic and religious plurality by seeking new marketing campaigns. Their approach was "The methods may change, but the message never does.” In Baltimore, I encountered many young adults who had left the Church they had grown up in. Many were very interested in spirituality, but not necessarily in organized religion. They might selfidentify as either "spiritual, but not religious" or "I love Jesus and hate the Church." These are just two instances in which increasing globalization, on the one hand, and increasing secularization, on the other, have dramatically changed the religious landscape in the United States over the last half-century.

Through my involvement with the emerging church movement in the U.S. and also with emerging Christian leaders in Africa, I then discovered the need for additional theological resources to understand and, in some way, address the contemporary situation. This dissertation turns to two theologians from outside the United States who I believe can serve as helpful guides for scholars in religious studies, especially Christian theologians, to navigate questions of increasing secularization and religious pluralism.

This project combines my religious background (I was raised in the Reformed tradition, specifically in the Presbyterian Church-USA) with my interest in Africa. I came to know of Karl Barth first through sermons, then through reading two unpublished 
dissertations on Barth written by mentors of mine, and then at Princeton Theological Seminary. Barth first offered a way for me to understand the Reformed tradition without being bound by sixteenth century questions. Although I had spent a summer during college in southern Africa and visited East Central Africa twice before beginning the doctoral program at the University of Virginia, I first read Kwame Bediako's work in preparation for a comprehensive exam in African Christianity. I quickly discovered intriguing overlaps with aspects of Barth's thought. Based on these initial discoveries and the realization that Bediako's work had barely been written about, I arranged a research trip to Ghana through a mutual friend of Bediako's widow.

During my visit, I came to see that Barth and Bediako had sought to answer quite similar questions about revelation, religion, and culture despite very different cultural backgrounds. Barth sought to articulate a new theology at the end of the modern period; Bediako sought to articulate theology in the aftermath of the colonial period. Further, I have come to believe an examination of each theologian individually, and a subsequent comparison of the two, promises to address several pressing concerns in contemporary theological scholarship - about articulating Christian claims in religiously pluralist societies and assessing new religious movements.

The dissertation tells the story of how these two theologians from diverse religious, cultural, and socio-political backgrounds both respond to the same phenomenon - namely, the failures of nineteenth century European Protestantism. Chapter 1 explores the claim that Barth received the tenets of this religious mindset directly from his teachers while Bediako received the same tenets indirectly through colonization. Chapter 2 analyzes the three major themes that emerge from Bediako's 
corpus: revelation, religion, and culture. These themes set the agenda for the rest of the dissertation. Barth treats these themes most directly in his mature Christology in Church Dogmatics IV/3, §69 — the text for the analysis in chapter 3. In this paragraph, Barth's exposition of the ongoing prophetic activity of Jesus Christ articulates his understanding of reconciliation as revelation: the work of Christ as prophet proclaims the justifying and sanctifying work of Christ as Priest and King. In chapter 4, the analysis is sharpened through a comparison of Bediako's and Barth's Christocentric theologies through their (a) diverse understandings of Christ's universality, (b) expositions of the Epistle to the Hebrews, (c) understandings of the three major themes, and (d) responses to the question "Are we all syncretists?" that integrates all three themes. Chapter 5 concludes by consolidating the insights on the themes of revelation, religion, and culture gleaned from these two theologians and the comparison. 


\section{Chapter 1 \\ Bediako, Barth, and Theology in the Twentieth Century}

Christ has been presented as the answer to the questions a white man would ask, the solution to the needs that western man would feel, the Saviour of the world of the European world view, the object of the adoration and prayer of historic Christendom. But if Christ were to appear as the answer to the questions that Africans are asking, what would he look like? ${ }^{1}$

[T] he Christian-bourgeois or bourgeois-Christian age has come to an end...that is, Christendom no longer exists in the form we have known...The world is reclaiming...its freedom (from the church)...But with that, the gospel's freedom over against the world has been restored to it. ${ }^{2}$

From radically different religious backgrounds and cultural locations, Kwame Bediako (1945-2008) of Ghana and Karl Barth (1886-1968) of Switzerland reflected theologically about the nature and scope of revelation. After the tumultuous events of the twentieth century suggested that many of the "plausibility structures"3 of Western Christianity had collapsed, these theologians sought to articulate anew the gospel of Jesus Christ amidst societies where one's religious beliefs are determined, in some sense over against others, not received by fate. ${ }^{4}$ Both multiple beliefs, and no belief, are possible. ${ }^{5}$

\footnotetext{
${ }^{1}$ Quoted in Kwame Bediako, "Jesus in African Culture: A Ghanaian perspective," in Jesus and the Gospel in Africa (Oxford: Regnum, 2000), 20; from John V. Taylor, The Primal Vision: Christian Presence amid African Religion (Philadelphia: Fortress Press, 1963), 24.

${ }^{2}$ Karl Barth, Das Evangelium in der Gegenwart (München: Chr. Kaiser, 1935), 33-34. Quoted by Eberhard Busch in The Great Passion: An Introduction to Karl Barth's Theology (Grand Rapids: Eerdmans, 2004), 170.

${ }^{3}$ See Peter L. Berger, The Sacred Canopy: Elements of a Sociological Theory of Religion (New York: Anchor Books, 1990).

${ }^{4}$ See Peter L. Berger, The Heretical Imperative: Contemporary Possibilities of Religious Affirmation (Garden City, NY: Anchor Press, 1979).

${ }^{5}$ Charles Taylor, A Secular Age (Cambridge, MA: Belknap Press of Harvard University Press, 2007), 12. Taylor writes, "there has been a titanic change in our western civilization. We have changed not just from a condition where most people lived "naïvely" in a construal (part Christian, part related to "spirits" of pagan origin) as simple reality, to one in which almost no one is capable of this, but all see their option as one among many" (Taylor, A Secular Age, 12, emphasis added).
} 
The delegitimization of Western Christianity's failed narrative has been described in the following manner:

Central twentieth-century events-World War II, the Shoah, Third World independence movements - all simultaneously delegitimized the West as axiomatic center of reference and affirmed the rights of non-European peoples straining against the yoke of colonialism and neocolonialism. Thus, if Nazism, fascism, and the Holocaust revealed in all their horror the "internal" sickness of Europe as a site of racist totalitarianism, the Third World liberation struggles revealed the "external" revolt against Western domination, provoking a crisis in the taken-for-granted narrative of European-led Progress. ${ }^{6}$

The collapse of this "taken-for-granted narrative,", often referred to as "Christendom"which I take to designate the yoking of the Christian faith to political power and cultural hegemony that began with Constantine I in the fourth century—-has left many Christians asking questions about how to proceed. ${ }^{8}$ The responses of Bediako and Barth are intriguingly similar: both sought to uncouple the connection between the gospel of Jesus Christ and culture that had been forged in the name of colonization in Africa and religion in Europe.

Through a finely grained comparison of these two theologians, this dissertation argues that Bediako's post-colonial theology and Barth's post-modern theology (with both "post-'s" used primarily in an historical, rather than theoretical, sense) offer helpful resources for engaging twenty-first century questions centered around three themes:

\footnotetext{
${ }^{6}$ Robert Stam and Ella Shohat, "Whence and Whither Postcolonial Theory?" New Literary History 43 (2012): 379 .

${ }^{7}$ Taylor writes: "[B]elief in God isn't quite the same thing in 1500 and 2000. I am not referring to the fact that even orthodox Christianity has undergone important changes (e.g., the "decline of Hell," new understandings of the atonement). Even in regard to identical creedal propositions, there is an important difference. This emerges as soon as we take account of the fact that all beliefs are held within a context or framework of the taken-for granted, which usually remains tacit, and may even be as yet unacknowledged by the agent, because never formulated" (Taylor, A Secular Age, 13, emphasis added).

${ }^{8}$ In the last decade, more the 20 books have been published with the title: "__ after Christendom." The blank has been filled in with "Mission," "Evangelism," "Ethics," "Gospel," "Church," "Worship," and "Faith and politics," among others.
} 
revelation, religion, and culture. The particular details of the comparison shape the narrative of the whole, rather than offering generalizations seeking supportive evidence. I argue, specifically, that the work of Bediako and Barth, each in its own way, anticipated the postcolonial critique of universalizing standards and mores in Christian theological reflection and the Christian life, yet offered a surprising alternative—namely, the only universal, Jesus Christ. Further, the comparison of the ideas of Bediako and Barth offered in this dissertation demonstrates the (often unexpected) ways in which their thought complements one another and what each might learn from the other. The project treats Bediako and Barth as theological peers who generate significant theological engagement that transcends cultural and geographic boundaries; it imagines an intra-Protestant conversation that has broad implications. Finally, it will become quickly clear that while the focus of this project is explicitly theological, in its attention to three themesrevelation, religion, and culture - it seeks to exemplify a practice of reflection for the twenty-first century that is not hegemonic and advocates for representatives of multiple perspectives and contexts in the task of constructive inquiry.

From across the colonial divide, both Bediako and Barth responded to the failings they saw and experienced in nineteenth and twentieth century European theology. In Germany and Switzerland, Barth criticized the lack of self-critical reflection in theological discourse regarding "religion," expressed through "culture Protestantism" (Kulturprotestantismus). ${ }^{9}$ In Ghana, Bediako criticized an intensification of a different kind—one that sought to "civilize" Africans through colonialism, as conveyed by European missionaries. Positively, both authors appealed to an understanding of God's

\footnotetext{
${ }^{9}$ For an excellent and detailed description of Kulturprotestantismus, see Gangolf Hübinger, Kulturprotestantismus und Politik: Zum Verhältnis von Liberalismus und Protestantismus im Wilhelminischen Deutschland (Tübingen: J.C.B. Mohr, 1994).
} 
revelation. Both believed that their "adversaries" had confused revelation and culture in the name of religion by using religious arguments to privilege cultural assumptions over a genuine wrestling with divine communication. And their shared hope was that through a fresh approach to revelation Christian theology could be rooted within the story of Jesus Christ, over against the religion of nineteenth century European Protestants. ${ }^{10}$

One of the primary reasons for comparing these two particular theologians, then, is the role that their respective historical and cultural contexts played in the shaping of their theological reflections. Even though Barth was taught the precepts of nineteenth century European Protestantism directly by his teachers, and Bediako received the same precepts indirectly through the colonial legacy, the work of both theologians responds to the same phenomenon. While Barth was observing what he took to be the increasing secularization of the Christian church in Europe, Christianity in sub-Saharan Africa, and in the global South more broadly, was growing exponentially, particularly after the departure of the colonizing authorities and many missionaries in the 1950s and 1960s. Some empirical data is telling. In 1910, 66\% of Christians worldwide lived in Europe and North America. In 2010, 61\% of Christians lived in the Global South (63\% of Africans are Christians). ${ }^{11}$ While the number of Christians worldwide has quadrupled over the last century to 2.2 billion, the proportion of the world population that is Christian has

\footnotetext{
${ }^{10}$ The polemics that Bediako and Barth present against nineteenth century Protestantism may not measure up to reality. For more balanced accounts of liberal Protestantism see, Claude Welch, Protestant Thought in the Nineteenth Century, 2 vols. (New Haven: Yale University Press, 1972), Bernard M. G. Reardon, Liberal Protestantism (Stanford, CA: Stanford University Press, 1968), and Gary J. Dorrien, Kantian Reason and Hegelian Spirit: The Idealistic Logic of Modern Theology (Oxford: Wiley-Blackwell, 2012), esp. "Idealism as White Supremacist Ordering," 542ff.

${ }^{11}$ Pew Research Center, "Global Christianity - A Report on the Size and Distribution of the World's Christian Population,” (2011), http://www.pewforum.org/2011/12/19/global-christianity-exec/, accessed February 11, 2014.
} 
remained constant at about one-third. Yet, in a dramatic change few saw coming, there are now nearly twice as many Christians in the global South than the global North.

The rapid growth of Christianity in Africa began to receive scholarly attention in the 1970s. David Barrett first identified the shift in "centre of gravity" in 1970 when he wrote,

by AD 2000 the centre of gravity of the Christian world will have shifted markedly southwards, from Europe and North America to the developing continents of Africa and South America...Christianity, long a religion of predominantly the white races, will have started to become a religion of predominantly the non-white races. ${ }^{12}$

Shortly thereafter, British church historian Andrew Walls expanded and interpreted Barrett's observation. ${ }^{13}$ By 2002, Philip Jenkins, in his widely read The Next Christendom: The Rise of Global Christianity, applied the phrase to the whole of Christianity in the global South as he anticipated a shift in ecclesial power from Europe and North America to Africa, Asia, and South America. ${ }^{14}$ While Jenkins hints that these changes will have a significant impact on future theological discussions, he offers little on the content of such impact.

Kwame Bediako and other African theologians, while thankful that many Westerners were finally noticing the rapid growth of Christianity in the global South

\footnotetext{
${ }^{12}$ David Barrett, “AD 2000: 350 Million Christians in Africa," International Reyiew of Mission 59:233 (January 1970): 49-50. Cited in Kwame Bediako, "New paradigms on ecumenical co-operation: An African perspective" International Review of Mission (July 1992): 375.

${ }^{13}$ Andrew F. Walls, "The Gospel as Prisoner and Liberator of Culture," in The Missionary Movement In Christian History: Studies In the Transmission of Faith (Maryknoll, NY: Orbis Books, 1996), 6. Walls first wrote about this change of the center of gravity within Christianity in 1971 in an article published as "Towards Understanding Africa's Place in Christian History," in J.S. Pobee (ed.), Religion in a Pluralistic Society (Leiden: E.J. Brill, 1976), 180-189. See Kwame Bediako, "The Willowbank Consultation, January 1978 - a personal reflection," Themelios 5:2 (January 1980): $26 \mathrm{n} 6$.

${ }^{14}$ Philip Jenkins, The Next Christendom: The Rise of Global Christianity (New York: Oxford University Press, 2002). Jenkins described the new 'southern' Christianity as "exotic, intriguing, exciting, but a little frightening" (220). See also his follow-up book that softened many of his earlier claims: Philip Jenkins, The New Faces of Christianity: Believing the Bible In the Global South (New York: Oxford University Press, 2006).
} 
through Jenkins' books, strongly disputed Jenkins' predictions of a "new Christendom." They claimed that Jenkins' conclusions result from his lack of experience amidst religious pluralism. Jenkins, from the United States (himself a Catholic-turnedEpiscopalian), lives in a society that is predominantly Christian, has historical roots in Christianity, and is experiencing increased religious pluralism that some find threatening. However, Bediako, as is typical for sub-Saharan Africans, grew up amidst religious pluralism. Traditional African religions and Islam, in addition to Christianity and African Independent Churches (AICs), are found throughout Ghana. Thus, for Bediako and other theologians in the global South, Christianity can —and often already does - co-exist with other religious traditions without seeking political domination. Indeed, since the experience of African Christianity has always included religious pluralism, both in the form of primal religions and Islam, Bediako suggests that Africa can help the West in the re-making of its theology. In such a process of re-making, the complex character of Christianity is manifest for fresh exploration and appraisal.

Bediako repeatedly refers to Christendom as a "disaster,", and is certain that "Africa has not produced and is not likely to produce, a new Christendom" (CiA, 249). ${ }^{16}$ For him, the core failure of Jenkins' work is how it "polarizes... [the] conservative, and probably innocent South, and the more sophisticated, liberal North...[This] persistent 'us and them' frame of reference... obscures the polycentric character of Christian presence in the world." ${ }^{17}$ On Bediako's reckoning, then, the growth of the Christian Church in the

\footnotetext{
${ }^{15}$ For instance: Kwame Bediako, "Islam and the Kingdom of God" (Stone lecture \#3, Princeton Theological Seminary, Princeton, NJ, October 21, 2003) and Kwame Bediako, "Africa and Christianity on the threshold of the third millennium: the religious dimension," African Affairs 99 (2000): 316.

${ }^{16}$ Of no minor significance, here, is that Bediako published these words six years prior to Jenkins' The Next Christendom.

${ }^{17}$ Kwame Bediako, “'Why has the summer ended and we are not saved?': Encountering the Real Challenge of Christian Engagement in Primal Contexts," JACT 11.2 (2008): 5.
} 
global South is not a new Christendom, rather, it is an authentic, indigenous expression of the Christian faith-outside of Europe and North America and within a religiously pluralistic environment — that creates multiple centers (or no geographic center!) of Christianity.

For Bediako, African Christianity offers hope and guidance to those stuck within a Christendom mindset that assumes that a "center-of-gravity" must exist and is based on a society focused on a single faith-tradition. Bediako understands Western Christianity to have been fatally wounded by the elimination of religious difference. He writes, "when the context of religious pluralism is succeeded by...a Christendom from which all possible alternatives are presumed eliminated, not only from the context, but from theological existence too, [then] the theological enterprise ceases to need to make Christian decisions. Because no other kinds of decisions are conceivable, the character of theology itself becomes changed" (CiA, 257). The total conquest and Christianizing of Europe eviscerated Europeans' primal religious pasts-groups like the Celts in presentday Ireland become the exception that proves the rule. A significant result of this character of Christendom theology can be an inability of Christian theologians to speak intelligibly with people outside the Christian faith. Likewise, a non-Christian will not be able to "encounter Christ except on the terms of a Christian theology whose categories have been established with little reference to the faiths of others" (CiA, 257). The implication of Bediako's claim, then, is that Western Christianity cannot continue to operate, ecclesiologically or theologically, on a Christendom-era model.

Bediako's theology is pertinent for contemporary theological reflection in Africa and in the United States. The influence of Christians of non-European descent on the 
practices of American Christianity has been increasingly documented. ${ }^{18}$ No longer can the trajectory of Christianity in America be understood as a linear development of European denominations and faith traditions. Formerly colonized peoples from around the world are now changing beliefs and practices within the United States, particularly within American Protestantism.

This changed cultural context calls for new theological reflection. Blindly continuing onward with centuries-old questions and answers treats Christianity as a static religion, not a living faith. Bediako offers another possibility, a new way forward. As will be shown in chapter 2, Bediako describes the dynamic encounter between gospel and culture as the "infinite translatability of the gospel of Jesus Christ." As will be shown in chapter 3, Barth describes the ongoing prophetic activity of Jesus Christ as God's enkindling presence that shines light throughout the world.

Individually and together, Bediako and Barth suggest new alternatives and provide resources to contemporary theological conversations. The comparison of their thought is aided by sharing similar vocational experiences and other common influences. Both men served as pastors at the beginning of their careers. Both were Protestants and in the Reformed tradition — though the precise understanding of what it meant to be "Reformed" was different for each. Neither set out to be a theologian. Bediako only felt compelled to pursue a vocation in theological education following his conversion. Barth jumped at the offer of a professorship after the acclaim for his groundbreaking

\footnotetext{
${ }^{18}$ See Mark Gornik, Word Made Global: Stories of African Christianity in New York City (Grand Rapids: Eerdmans, 2011); Jacob K. Olupona and Regina Gemignani, African Immigrant Religions in America (New York: New York University Press, 2007); and Soong-Chan Rah, The Next Evangelicalism: Freeing the Church from Western Cultural Captivity (Grand Rapids: InterVarsity Press, 2009).
} 
commentary, The Epistle to the Romans, ${ }^{19}$ even though he did not have a doctorate. On the other hand, Bediako earned two doctorates (one in Francophone literature and one in Patristic theology). Barth wrote prolifically_including his twelve volume Church Dogmatics of over eight thousand pages; Bediako wrote only two monographs, but over seventy-five articles and book chapters. Bediako founded and administrated a research institute and school, the Akrofi-Christaller Institute for Theology, Ministry, and Culture in Akropong-Akuapem, Ghana. ${ }^{20}$ Barth did not hold any administrative positions and he eschewed the possibility of founding a school of thought, as some nineteenth century theologians-Albrecht Ritschl and others—-had done. Indeed, Barth concludes his 1953 preface to Church Dogmatics IV.1, with gratitude for the freedom he has had to devote himself to his own writing, without the added burdens of overseeing a movement or institution:

To conclude, I often think that there are few men who have cause to be so grateful to God and man as I have. I am still in good heart, and - without having to carry the dignity and responsibility of being head of a school (Schulhauptes) - I can devote myself to this great task surrounded with as much consideration and loyalty. The result is that although the task is a heavy one I do not have to stagger under its weight, but year in year out it carries me along with it. I now turn to it again. The way is long. But "having still time on the earth ..." (IV.1, x; emphasis added).

Barth's prolific and prodigious writing career — that spanned over five decades—was fueled through the discipline of preparing lectures and engagement with students and not inhibited by other responsibilities. Bediako, by contrast, poured his energies into establishing the Akrofi-Christaller Institute (through administration and fundraising) as

\footnotetext{
${ }^{19}$ Karl Barth, Der Römerbrief, $1^{\text {st }}$ ed (Bern: G. A. Bäschlin, 1919). Future citations will come from the revised second edition, Karl Barth, Epistle to the Romans, $2^{\text {nd }}$ ed., trans. Edwyn C. Hoskyns (London: Oxford University Press, 1968 [1933]).

${ }^{20}$ For current updates on the Akrofi-Christaller Institute of Theology, Mission, and Culture, see: http://www.acighana.org.
} 
the first theological institution in Ghana that could grant doctoral degrees. He squeezed his writing into the margins of his hectic schedule, usually in preparation for a conference or a public lecture.

Bediako's corpus is an example of writing from the margins of the empire back to the center of theological power and production in the West. ${ }^{21}$ Although Barth found himself geographically and culturally near the center, his theological work placed him outside the center, criticizing the liberal Protestant consensus. Both theologians used their understandings of God's revelation to confront accepted and prevailing norms in religion and culture. Their economic, social, political, and cultural contexts shaped their identities and interests; they wrote specifically for those settings.

The next two sections of this chapter will consider the formative factors in their theological development—Bediako first (I), followed by Barth (II). Then, section III addresses the common Protestant inheritance that Bediako and Barth share that places their theological contributions within a larger intra-Protestant conversation. The mutual suspicion that each theologian has of the other (for Bediako, of Western theology as insular with a history of oppression; and for Barth, of Africans not being serious interlocutors) is documented in section IV. The fifth section introduces the three themes - revelation, religion, and culture - that flow through the dissertation. The chapter concludes with an overview of the shape of whole argument of the dissertation.

\footnotetext{
${ }^{21}$ For this imagery, see Bill Ashcroft, Gareth Griffiths, and Helen Tiffin, The Empire Writes Back: Theory and Practice In Post-colonial Literature (London: Routledge, 1989).
} 


\section{I.}

\section{Bediako: An African in Europe and the World}

Manasseh Kwame Dakwa Bediako was born in the Gold Coast, a British colony, on July 7, 1945. His first name honors his father, Ephraim Nkansah Bediako; his second name is the traditional Akan (his family's tribe) name for a baby boy born on Saturday; his third name honors his paternal grandfather, Dakwa, a catechist with the Basel Mission. Bediako had a simple upbringing in Tesano on the north side of the capital city, Accra, with nine brothers and sisters as the first son of a police inspector. At this time, World War II was drawing to a close and colonized nations around the world were mobilizing for freedom. Four years later, India achieved independence from Britain in 1949. In 1957, as the first nation in sub-Saharan Africa to become independent, the Gold Coast took the name Ghana; Bediako was nearly twelve years old. His childhood was spent under colonial rule and in his adolescence he watched as Kwame Nkrumah, Ghana's first Prime Minister and President, articulated his understanding of panAfricanism and sought to lead a young nation-state to engage the wider modern world.

After middle school, Bediako gained entrance to the Mfantsipim School in Cape Coast, where Kofi Annan, later Secretary General of the United Nations, was a few years his senior. ${ }^{22}$ There he "distinguished himself not only academically, but also as an outstanding School (Head) Prefect, nicknamed 'Joe Noir,' loved and respected by all the boys, despite his being a strong disciplinarian."23 At Mfantsipim, Bediako was taught by a white South African, Peter Denton, and took his A-Levels in English Literature, French, and Latin. His classmates remembered him as "among the best in our group of very fine

\footnotetext{
${ }^{22}$ Hans Visser and Gillian Mary Bediako, Jesus and the Gospel in Africa (Oxford: Regnum, 2000), xi.

23 "Call to Glory," Funeral program for Kwame Bediako July 2008, unpublished, 3.
} 
scholars...the quintessential black man" who "excelled" at English oratory. ${ }^{24}$ They

"thought he was better cut for the Legal Profession" and were later shocked that he had

become a preacher and theologian. ${ }^{25}$ Upon graduating in 1969 with an honors degree in

French studies from the University of Ghana, Legon, Bediako was awarded a scholarship

from the French government for post-graduate study at L'université de Bordeaux III, as

well as a supplemental bond from the University of Ghana, with a view to returning to

lecture. $^{26}$

As I will consider in more detail in chapter 2, Bediako's early academic influences, particularly his study of the French existentialists as an undergraduate, ${ }^{27}$ had led him to become a self-avowed atheist in contrast to his upbringing where his family participated in the local congregation of the Presbyterian Church of Ghana as well as in many traditional religious practices of the Twi people. ${ }^{28} \mathrm{He}$ describes the years of his undergraduate studies, 1965-69, as "a phase of self-conscious atheism” (Ebenezer, 4). Bediako later understood his conversion to Christianity as a rejection of what he experienced as Western atheism and an embrace of African religiosity. He writes,

Curiously, my increasing exposure to Western intellectual culture, particularly through my French Studies, had not led me to find Christ; instead, it made me an atheist who thought that God was irrelevant to my intellectual development. In becoming a Christian, and in finding how

\footnotetext{
24 "Tribute to the late Rev Professor Kwame Bediako by Mfantsipim Old Boys Association, Class of '63," in "Call to Glory," 23.

25 "Call to Glory," 23.

26 "Call to Glory," 19.

${ }^{27}$ Bediako had drunk deeply from the well of Western intellectual culture through his study of European existentialists such as Jean-Paul Sartre, Simone de Beauvoir, Albert Camus and André Malraux. See Kwame Bediako, "Worship as vital participation- some personal reflections on ministry in the African church" JACT 8.2 (2005): 4.

${ }^{28}$ Bediako recounted how his father took his to the traditional shrine to give thanks following his healthy return from France. Hans Visser and Gillian Mary Bediako retold the story: "When he returned to Ghana in 1976, his father proposed to thank the shrine-spirit for his safe return. Kwame explained to him that he had come to understand that it was Jesus who protected him. His father replied, 'If Christ protects you now, that's fine. We do not need to go to the shrine.' Then Kwame said, 'He protects you too, father. He is the wall surrounding us"' Jesus and the Gospel in Africa, xii.
} 
God is central in all life, I was very conscious that I was recovering my African identity and the spiritual view of life. The consciousness of having become an African Christian made a profound impression upon me. It gave me a desire to study theology as a discipline, in the hope that it would help me understand what had happened to me (Ebenezer, 4).

In hindsight, Bediako understood the lasting impact of colonization on him to be atheism, not Christianization. Contrary to missionary hopes, Bediako's journey had taught him that one could be "Western" without God or religion. Yet, he believed that to be African was to be "incurably religious. ${ }^{, 29}$ As such, by renouncing atheism and becoming a Christian, Bediako understood himself to be recovering his African identity and the African spiritual view of life. His future theological vocation can be understood as an extended exercise in understanding "what had happened to [him]" (Ebenezer, 4)—and many other Africans. The following paragraphs demonstrate how, for Bediako, an integrated understanding of the connection between one's intellect, spirit, identity, and all of life countered the colonial mindset. His writings sought to overcome the colonial legacy in theological discourse that he first encountered as a school boy.

Bediako's life and work was indelibly marked by his experiences with colonialism. His grandfather was a catechist with the Basel mission, his education in middle and high school was in a missionary-founded school begun by the Methodists, his academic subjects considered the histories of other people as he learned Latin, Greek, and French, and the histories of civilizations outside of Africa. ${ }^{30}$ His scholarly talents

\footnotetext{
${ }^{29}$ The original quotation, "Africans have been called incurably religious," comes from Geoffrey Parrinder, Religion in Africa (Harmondsworth: Penguin Books, 1969), 235. Parrinder's claim has been deeply contested. See Jan Platvoet \& Henk van Rinsum, "Is Africa incurably religious?: Confessing and Contesting an invention" Exchange 32:2 (2003): 123-153; and Kehinde Olabimtan, "'Is Africa Incurably Religious?' II: A Response to Jan Platvoet \& Henk van Rinsum,” Exchange 32:4 (2003): 322-339. When he wrote his response, Olabimtan was on the staff of the Akrofi-Christaller Centre where Bediako was the founder and director.

${ }^{30}$ Kamau Brathwaite of Barbados describes the experience of colonized peoples in Africa and the diaspora who were given not only a religious system that was foreign to them, but an entire religious and cultural
} 
were consistently applied to mastering Western intellectual traditions. His university honors degree was rewarded with a scholarship to the metropole. Bediako was prepared - groomed, even — to function and succeed in the Western European "world." And, in his early life, Bediako conformed to the expectations placed upon him even in his atheistic religious beliefs.

Deeply influenced by the work of Frantz Fanon, ${ }^{31}$ Bediako abandoned the "Church in the colonies [that] is a white man's Church, a foreigners' Church. It does not call the colonized to the ways of God, but to the ways of the white man, to the ways of the master, the ways of the oppressor." 32 If God was responsible for colonization and its horrors, including slavery, who would want to believe in God? While rejecting the "religion of the white man," Bediako may have sensed that pursuing higher educationeven in France of all places — might lead to a way out of the colonial dichotomies that Fanon identified, such as Christian/pagan, civilized/savage, chosen/rejected, saved/damned, redeemed/guilty, rich/poor, white/black. ${ }^{33}$ An education in French African literature and the cultural resistance movement known as négritude could possibly help give future generations of Ghanaians the tools to shape a post-colonial national identity. Bediako's graduate work in France began to demonstrate the cracks in his conformity to Western thought patterns and his assertion of his own African identity. His choice to research the poetry of Tchicaya U Tam'si, a Congolese poet living in Paris,

\footnotetext{
history that was foreign: "People were forced to learn things that had no relevance to themselves. Paradoxically, in the Caribbean (as in many other "cultural disaster" areas), the people educated in this system came to know more, even today, about English kings and queens than they do about our own national heroes, our own slave rebels - the people who helped build and to destroy our society." See Kamau Brathwaite, "History of the Voice," in Roots: Essays in Caribbean Literature (Ann Arbor: University of Michigan Press, 1993), 263.

${ }^{31}$ Bediako engaged Fanon's work in both his master's and doctoral theses at the University of Bordeaux.

${ }^{32}$ Frantz Fanon, The Wretched of the Earth (New York: Grove Press, 2004 [1961]), 7.

${ }^{33}$ Frantz Fanon, Wretched of the Earth, 6, 15, 43.
} 
who wrestled with issues of colonialism, faith, and identity, allowed Bediako to undertake a similar questioning. As will be shown in chapter 2, both of Bediako's unpublished French works demonstrate the outworking of his desire to "understand what had happened to" him in his conversion to Christianity while in Bordeaux (Ebenezer, 4). The master's thesis evinces hints of his personal anguish and yearning for a more settled existence. The doctoral thesis can be read as Bediako's awkward first attempt to integrate the experiences of Africans with Christian teachings. It aims to articulate an understanding of the Christian faith that addressed African needs and answered African questions.

Bediako's later work intensified this line of thought: He came to understand his entire intellectual project to be indigenous, in that it originated in and was written for Africa. As a self-consciously autochthonous thinker, he sought to articulate and explain the African roots of his personal identity and that of African Christianity as a whole. In doing so, he argued that the insights of African Christianity are revelatory for the understanding of the Christian faith worldwide. Indeed, for Bediako, the process of translating the gospel of Jesus Christ into African languages and African concepts provides a fuller understanding of the gospel itself. Bediako understood that, "the very process of the cross-cultural transmission of the Gospel can also be revelatory" (CiA, 214), such that the experiments in Christian thought within the "laboratory" of Africa reveal who God is (CiA, 252). ${ }^{34}$ Most strikingly, he claimed that God's revelation has a potential impact on all Christians and understandings of the essence of Christianity.

\footnotetext{
${ }^{34}$ See also CiA, 265; Bediako, “'In the Bible, Africa walks on familiar ground.': Why the World needs Africa" AICMAR Bulletin 6 (2007): 34; and Bediako, "Types of African Theology" in Christianity in Africa in the 1990s, eds. C. Fyfe and A. Walls, (Edinburgh: University of Edinburgh, Centre for African Studies), 56.
} 
These experiences of African Christians, and African Christian theology, more broadly, encourage the re-making of Christian theology itself.

Throughout his nearly forty years of writing, Bediako's corpus (two unpublished theses, two monographs, one volume of collected essays, and over seventy-five articles and book chapters) can be divided into three phases of composition. While the themes of his work can be tracked throughout his career, and his thought displays a remarkable degree of consistency, the inflection and articulation of his themes vary as the locations and the explicit or implicit audiences of his writings change. For the purposes of this project, it seems appropriate to divide Bediako's writings into three phases:

1. 1969-1984: "In Europe"

2. 1984-1998: "Back and Forth between Africa and Europe"

3. 1998-2008 (-2011): "Pan-Africanism"

The first phase of Bediako's writing, 1969-1984, began at the University of Bordeaux for a master's and doctorate in Francophone literature, followed by a bachelor's in divinity at London Bible College, and a brief two year return to Ghana in 1976-1978. It concluded at the University of Aberdeen with a PhD dissertation in Patristic theology, supervised by Andrew Walls. Aside from three short articles and two book reviews published in 19781980, the writings from this phase were unpublished, although a lightly edited version of his Aberdeen PhD was published nine years later. This phase spanned Bediako's twenties and thirties (from age twenty-four to thirty-nine), and took place primarily in Europe, aside from two years teaching at the Christian Service College in Kumasi, Ghana.

The completion of his theological doctorate at Aberdeen marked the conclusion of the first phase and the beginning of the second, and most productive, stage in Bediako's writing, spanning ages thirty-nine to fifty-three (1984-1997). Following a year teaching 
with Andrew Walls in Aberdeen, Bediako returned to Ghana in September 1984. He had been ordained by the Presbyterian Church of Ghana - that had been founded by the Basel Mission and later organized by the Church of Scotland — and was now posted to Accra Ridge Church as Presbyterian and Resident Chaplain. Ridge Church is an interdenominational, international English-speaking congregation. ${ }^{35}$ Bediako spent three years there cultivating contacts for the beginnings of a mission research center and started his yearly travels to Europe. Whereas the first period was spent almost solely in Europe, in his second stage, while living in Ghana, he spent three months each year in Scotland. During the fourteen years of this stage, Bediako spent the first three split between Accra and Aberdeen; the following eleven were split between Akropong and Edinburgh as the Akrofi-Christaller Mission Centre was launched in 1987 and Andrew Walls' Centre for the Study of Christianity in the non-Western world moved to Edinburgh in 1986, following Walls' retirement from Aberdeen. ${ }^{36}$ This back-and-forth between Africa and Europe encouraged Bediako to write in a somewhat curious way: as an African for European audiences. His three-month long stays in Europe also allowed him to reflect, write, and rest from the responsibilities of beginning the research institute in Ghana. Bediako reflected in 2005 on how his time in Scotland and in Ghana during this phase affected his writing: "These annual visits to Edinburgh provided the space and the

\footnotetext{
${ }^{35}$ Emmanuel Lartey, currently Professor of Pastoral Theology, Care and Counseling at the Candler School of Theology at Emory University in Atlanta, GA, served as the Methodist Chaplain at Ridge Church at the same time. Previously, Lartey had attended the Mfantsipim School a couple years behind Bediako.

${ }^{36}$ More specifically, during his first year at Ridge Church, Bediako was also a part-time Tutor at Trinity College, Legon (ministerial training college for the Protestant churches in Ghana)—October 1984 to December 1985. In 1984, he also began his role as Director and Faculty member at the Oxford Centre for Mission Studies in Oxford, England. In 1985, he was an honorary visiting Fellow at the Centre for the Study of Christianity in the Non-Western World in Aberdeen before becoming a Visiting fellow of the Divinity Faculty, at the University of Edinburgh in 1986. From 1987-1992, Bediako served as the Duff Lecturer at Edinburgh, followed by his service as a Visiting lecturer in African Theology at Edinburgh from 1992-1998.
} 
opportunity...to be working on the book Christianity in Africa: The Renewal of a NonWestern Religion. I drew a good deal of the initial foundation materials for my Duff lectures from our learning experience and local programmes in Akropong” (Ebenezer, $18)$.

This second phase contained the publication of both of his monographs and almost forty chapters and articles. The theological dissertation, completed in 1983, was published in 1992 as Theology and Identity. ${ }^{37}$ The Duff lectures Bediako gave at Edinburgh from 1987-1992 were published in 1995 as Christianity in Africa. ${ }^{38}$ Bediako wrote five articles from 1990 to 1997 that were compiled with an introduction by Hans Visser and Bediako's wife, Gillian Mary Bediako, in Jesus and the Gospel in Africa (published in 2000).

The last decade of Bediako's life marked the final phase of his work (1998-2008, aged fifty-three to sixty-three). The period of formally splitting his time between Ghana and Scotland ended in 1998 and coincided with the beginning of a partnership with the University of Natal, Pietermaritzburg, South Africa in 1997. This pan-African theological partnership (which would last until 2004) and the launching of the Journal of African Christian Thought in 1998 marked the beginning of this phase. The phase concluded with Bediako's death of liver cancer in June 2008 following over a year of sickness and reduced activity. Seven articles and book chapters appeared posthumously from late 2008 to 2011. (For a complete chronological bibliography of Bediako's work, see the Appendix.) Two significant articles appeared at the beginning of this phase followed by

\footnotetext{
${ }^{37}$ Kwame Bediako, Theology and Identity: the impact of culture on Christian thought in the second century and modern Africa (Oxford: Regnum, 1992). Abbreviated as TI.

${ }^{38}$ Kwame Bediako, Christianity in Africa: Renewal of a Non-Western Religion (Edinburgh: Edinburgh University Press, 1995). Abbreviated as CiA.
} 
three significant lecture series. ${ }^{39}$ These lectures comprised the most significant and lasting theological contribution of this third phase. Bediako's widow described the 2006 AICMAR lectures in Nairobi as the pinnacle, or at least the last, full, exposition, of his thought. ${ }^{40}$ In my judgment, Bediako's final public appearances, following the onset of cancer symptoms in March 2007, point toward the remaking of Christian theology-an issue of some importance that I will engage in detail subsequently. For the purposes of this introduction, let us now turn to the work of Karl Barth and the context of his writing.

\section{II.}

\section{Barth: A European in Switzerland and Germany}

Until the 1970's Barth tended to be read as if his theological contributions were timeless, atemporal, and arose out of a vacuum. In 1972, however, Friedrich-Wilhelm Marquardt in his Theologie und Sozialismus ${ }^{41}$ insisted that Barth's theology "was always directed to a particular situation and really had no intention of being 'timeless.",42 This dissertation takes Marquardt's claim seriously, while eschewing his reductive analysis of Barth's thought. I read Barth with attention to his context, thinking with-and-beyond Barth with an eye towards the constructive possibilities present in his thought for engaging twenty-first century questions. Accordingly, this section presents a brief

\footnotetext{
${ }^{39}$ Kwame Bediako, "The Doctrine of Christ and the Significance of Vernacular Terminology" International Bulletin of Missionary Research 22:3 (July 1998): 110-111 and Kwame Bediako, "Africa and Christianity on the threshold of the third millennium: the religious dimension." African Affairs 99 (2000): 303-323. The lectures were: the Stone Lectures at Princeton Theological Seminary in 2003; on J.B. Danquah in Accra in 2004 (published 2006); and the AICMAR lectures in Nairobi 2006 (published 2007).

${ }^{40}$ Interview with Gillian Mary Bediako, Akrofi-Christaller Institute, Akropong-Akuapem, Ghana; 1 June 2012.

${ }^{41}$ Friedrich-Wilhelm Marquardt, Theologie und Sozialismus: Das Beispiel Karl Barths ( ${ }^{\text {rd }}$ edition; Münich: Chr. Kaiser, 1972).

42 Bruce L. McCormack, Karl Barth's Critically Realistic Dialectical Theology: Its Genesis and Development 1909-1936 (Oxford: Clarendon Press, 1995), 27.
} 
account of the shift in Barth's early theological thinking that informed his lifelong understanding of his work as a theologian to be one of witness, that is, pointing to Jesus Christ regardless of the circumstances he encountered in twentieth century Europe.

Karl Barth was born on May 10, 1886 in Basel, Switzerland. His father was a pastor and a professor who had received a doctorate for his study on Tertullian's interpretation of Paul. ${ }^{43}$ Both of Barth's grandfathers also had been pastors in Basel from the mid-nineteenth century onwards. At the age of four, Barth's family moved to Berne, though he always considered himself to be "from" Basel. He pursued the academic study of theology and was trained in the tradition of Protestant liberalism. ${ }^{44}$ After a pastoral internship at John Calvin's former parish in Geneva, Barth moved to the working-class town of Safenwil, Germany for his first parish in 1911, where he stayed for ten years. Soon after arriving, he learned of the experiences of the workers there and quickly became active agitator in movements for workers' rights. ${ }^{45}$

Although much can be said about this early stage in Barth's career (before his 1919 Romans commentary), for the purposes of this dissertation the significant aspects of this period are how Barth understands his "break with liberalism" in 1914 and his meeting with Christoph Blumhardt for five days in 1915. Looking back in 1957 (during the time that the material for Church Dogmatics IV.3 was delivered as student lectures in Basel), Barth famously reflected in an address at Hanover entitled, "Panorama of a Century":

\footnotetext{
${ }^{43}$ Eberhard Busch, Karl Barth: His life from letters and autobiographical texts (London: SCM Press, 1976), 1.

${ }^{44}$ As noted earlier, the tradition of Protestant liberalism is varied and complex. For sources of a more detailed analysis than is possible here, see page 12, footnote 10 .

${ }^{45}$ For more on Barth's politics see George Hunsinger, ed., Karl Barth and Radical Politics (Philadelphia: Westminster Press, 1976), particularly Barth's 1911 address "Jesus Christ and the Movement for Social Justice," 19-45.
} 
One day in early August 1914 stands out in my personal memory as a black day. Ninety-three German intellectuals impressed public opinion by their proclamation in support of the war policy of Wilhelm II and his counselors. Among these intellectuals I discovered to my horror almost all of my theological teachers whom I had greatly venerated. In despair over what this indicated about the signs of the time I suddenly realized that I could not any longer follow either their ethics and dogmatics or their understanding of the Bible and of history. For me at least, $19^{\text {th }}$-century theology no longer held any future. ${ }^{46}$

The final line of the quotation is the most significant: "For me at least, $19^{\text {th }}$-century theology no longer held any future." Broadly, Barth claims to be rejecting the same nineteenth-century European theology that Bediako rejected. Barth gave up following the "ethics and dogmatics" of his teachers and continued to seek a new direction for his theological work.

Although Barth identified the moment of his break with theological liberalism as a "sudden" realization in August 1914, Bruce McCormack has pointed to more of a process: "the ethos of the liberal world had become alien to him at a much earlier point in time...Expressed positively: if Barth's disappointment over the ethical failure of his theological teachers was the impetus which sent him in search of a new theology, his search for a new world had been set in motion much earlier."47 Granted Barth's recollection, the "break" did not occur overnight; it already had been influenced by Barth's reading of leading socialist thinkers and his political activism in Safenwil. ${ }^{48}$ At

\footnotetext{
${ }^{46}$ Karl Barth, "Evangelical Theology in the $19^{\text {th }}$ Century," in Humanity of God (Louisville: Westminster John Knox Press, 1960), 14, emphasis added. Translated from Karl Barth, "Evangelische Theologie im 19. Jahrhundert,” Theologische Studien Heft 49 (Evangelischer Verlag, Zollikon-Zürich, 1957), 6.

${ }^{47}$ McCormack, Critically Realistic, 78, 79; McCormack's emphasis.

${ }^{48}$ One significant influence is Hermann Kutter's They Must: Or, God and the Social Democracy. A Frank Word to Christian Men and Women (American ed. Chicago: Co-operative Printing Co, 1908). According to McCormack, Kutter "saw in socialism a kind of secular 'parable of the Kingdom'-a demonstration in deeds as well as in words of a vision of a new world which bore clear witness to that Kingdom which Jesus had proclaimed" (Critically Realistic, 83). See especially Kutter's quotation of Friedrich Naumann's The Social Program of the Evangelical Church (1892), They Must, 65-67.
} 
this time, Barth "was now ripe for a fundamental change of direction in his thinking."49 His encounter with Christoph Blumhardt offered content to this new direction and is more likely the decisive moment.

In April 1915, eight months after Germany's declarations of war and invasion of Belgium, Barth spent five days in Bad Boll with Christoph Blumhardt. McCormack refers to this year, August 1914-August 1915, as the moment when Barth's theology developed its new beginning. McCormack titled his book after his description of this moment as "critically realistic... The most immediate consequence of this new startingpoint in thought was the fact that criticism of religion moved to the centre of Barth's concerns." ${ }^{50}$ Yet on the two pages that McCormack discusses the impact of Christoph Blumhardt and his father Johann Blumhardt on Barth's theological development, he does not acknowledge the ongoing impact of the Blumhardts beyond $1915 .^{51}$ This ongoing impact is significant for my comparison of Bediako and Barth.

Both Hans Frei and Eberhard Jüngel have identified the significant impact of the Blumhardts on Barth in 1915..$^{52}$ Jüngel also noted the ongoing impact of the Blumhardts for the rest of Barth's career (Frei's dissertation was completed before IV.3 was published). He writes, "By the time Barth began to stray from his teachers' theology, he had read not only Overbeck, but also the two Blumhardts and Friedrich Zündel. And Barth remained theologically close to the two Blumhardts for the rest of his life. He knew that he was in their debt." ${ }^{53}$ Jüngel then cites from The Christian Life, §78.3, when Barth

\footnotetext{
${ }^{49}$ McCormack, Critically Realistic, 123.

${ }^{50}$ McCormack, Critically Realistic, 129, 130-131.

${ }^{51}$ See McCormack, Critically Realistic, 123-124.

52 Eberhard Jüngel, Karl Barth: A Theological Legacy, trans. by Garrett E. Paul (Philadelphia: The Westminster Press, 1986), 63-65; and Hans Frei, "The Doctrine of Revelation in the Thought of Karl Barth, 1909 to 1922: The Nature of Barth's Break with Liberalism” (PhD diss., Yale University, 1956).

53 Jüngel, Karl Barth, 63.
} 
lauds the Blumhardts in his last student lectures. More recently, Christian Collins Winn has offered a more expansive account of the Blumhardts' influence: “Their persistent presence as theological interlocutors makes plausible the presupposition that the Blumhardts' life and thought influenced Barth both in the deeper structures of his thought as well as in some of its thematics. ${ }^{, 54}$ This seems correct. The implications of Barth's new starting point lasted the rest of his life. Barth's understandings of the resurrection, the Holy Spirit, and the present and coming Kingdom of God, in particular, are all indebted to the influence of the Blumhardts (IV.3, 168-171/192-195; TCL, 256-257/443444).

The question then is to clarify more precisely how these diverse contextual issues - the support of the Kaiser's war-mongering by Barth's teachers, the disillusionment with "liberal theology," and the meeting with Christoph Blumhardtinfluenced Barth's thought. For Timothy Gorringe, "The impact of the Blumhardts on Barth can hardly be overestimated." 55 McCormack writes, "From now on [August 1915], knowledge of God - the a priori of all true representation of the Kingdom — would be the central question in Karl Barth's new theology." ${ }^{, 56}$ Barth himself described the immediate impact of Christoph Blumhardt upon his thought in September 1916: "Blumhardt always begins right away with God's presence, might, and purpose: he starts out from God; he does not begin by climbing upwards to Him by means of contemplation and deliberation. God is the end, and because we already know Him as the beginning, we may await His

\footnotetext{
${ }^{54}$ Christian T. Collins Winn, Jesus Is Victor!: The Significance of the Blumhardts for the Theology of Karl Barth (Eugene, OR: Princeton Theological Monograph Series-Pickwick Publications, 2009), xix. For his comments on McCormack's omission of the Blumhardts, see 28-31.

${ }^{55}$ Timothy Gorringe, Karl Barth: Against Hegemony (New York: Oxford University Press, 1999), 34.

${ }^{56}$ McCormack, Critically Realistic, 125.
} 
consummating acts. ${ }^{, 57}$ In his later work, Barth commented on the Blumhardts' insight that "Jesus is Victor": "in content, far from having the character of a new revelation, it merely sums up and succinctly formulates many New Testament sayings behind which there may be seen either directly or indirectly the central witness of the whole of the New Testament" (IV.3, 168/192). ${ }^{58}$ Barth's appropriation of metaphors and themes from the Blumhardts, then, was "not a repristination, but was rather constructive and creative."59 The work of the Blumhardts significantly influenced Barth's Christological approach and his understanding of the victory of Christ in the resurrection and Christ's ongoing activity in and through the kingdom of God as well as their interrelationship. Barth employed the Blumhardts' language of "Jesus is Victor" in $§ 69.3$ and "Thy Kingdom Come” in $\S 78.3$ to affirm the primacy of the resurrection to Christ's reconciling and prophetic work.

On two occasions, Barth tied together the connection between his disappointment with his "liberal" teachers and the future that the Blumhardts provided. Looking back in 1927, he wrote, "In the midst of this hopeless confusion [at the beginning of the War in 1914], it was the message of the two Blumhardts with its orientation on Christian hope which above all began to make sense to me." 60 The Blumhardts offered hope amidst the

\footnotetext{
${ }^{57}$ Karl Barth, "Afterword” in Christoph Blumhardt, Action in Waiting (Rifton, NY: Plough Publishing House, 2012), 151.

${ }^{58}$ See also Christian Collins Winn: "What we want to highlight here is that the Blumhardts were and remained important to Barth for no other reason than that he believed that their position and movement of thought represented an authentic recovery of the central dynamic of the New Testament. That the kingdom of God, embodied in Jesus Christ, was, is, and will be present in history as it moves towards its final end, the definitive extension and revelation of the transformation of the cosmos; that this reality cannot be controlled by human action, thought, or theological construction, but can only be hoped for within the same; and that the kingdom of God is God's kingdom, present, on the move, sometimes hidden, other times in the open, and yet never the result of human action, precisely because the ultimate sign and power of the kingdom was the resurrection of Jesus Christ. All of these insights could be affirmed by Barth, because he believed that they were and could be confirmed by an authentic and careful reading of Scripture and reflection on "die Sache" (i.e., "the reality") found therein (Collins Winn, Jesus Is Victor!, 212-213).

${ }^{59}$ Collins Winn, Jesus Is Victor!, 274.

${ }^{60}$ Karl Barth, Falkultätsalbum der Evangelisch-theologischen Fakultät (Münster, 1927), quoted in Busch, Life and Letters, 84.
} 
"black day" when his teachers endorsed Germany's war efforts. Later, at the very end of his life in the "Concluding Unscientific Postscript" appended to his Theology of Schleiermacher, Barth wrote:

From Blumhardt I learned just as simply (at least at the beginning) what it meant to speak of Christian hope...then the First World War broke out and brought something which for me was almost even worse than the violation of Belgian neutrality - the horrible manifesto of the ninety-three German intellectuals who identified themselves before all the world with the war policy of Kaiser Wilhelm II and Chancellor Bethmann-Hollweg. And to my dismay, among the signatories I discovered the names of almost all my German teachers (with the honorable exception of Martin Rade). An entire world of theological exegesis, ethics, dogmatics, and preaching, which up to that point I had accepted as basically credible, was thereby shaken to the foundations, and with it everything which flowed at that time from the pens of the German theologians. ${ }^{61}$

The hope that Christoph Blumhardt taught offered succor to Barth and his theological reflection. Instead of following his teachers and placing his hope in the German warmachine, Barth followed the Blumhardts by placing his hope in Jesus Christ alone; a hope grounded in the resurrection.

As occurred in 1914-1915, Barth's thought was deeply influenced by the people and events around him. His work was addressed to particular situations as well; in this sense, Barth is a contextual theologian. ${ }^{62}$ Barth wrote in 1957: "My thinking, writing and speaking developed from reacting to people, events and circumstances with which I was involved, with their questions and their riddles." ${ }^{, 63}$ Yet, to be contextual for Barth, meant reading contemporary circumstances as always subordinate to God's self-revelation in Jesus Christ. Most succinctly, in an article about his retirement from teaching, Barth recalled advising young theologians "to take your Bible and take your newspaper, and

\footnotetext{
${ }^{61}$ Karl Barth, "Unscientific Concluding Post-Script," in Theology of Schleiermacher (Grand Rapids: Eerdmans, 1982), 263-264.

${ }^{62}$ Gorringe, Karl Barth, 1.

${ }^{63}$ Busch, Karl Barth: His Life and Letters, 421.
} 
read both. But interpret newspapers from your Bible." ${ }^{64}$ For Barth, theological reflection (as an expression of Biblical interpretation) occurs within a context, but should not be driven by, nor bound to, that context.

Barth’s biographer and last assistant, Eberhard Busch, described Barth’s thoughtprocess and approach to doing theology in public as follows:

At the time when Barth was working on his Church Dogmatics he was outwardly pressured by many external responsibilities on which he adopted pointed, fearless, and often offensive positions. Undoubtedly the two lines of activity, the internal and the external, were related. What took place outwardly was a kind of commentary on that to which he was devoting himself at the inner level. ${ }^{65}$

While commenting on current events, authors, and circumstances, Barth always understood his work as a theologian to be one of a witness - that is to be following in the legacy of John the Baptist — as one always pointing to Jesus Christ, and the hope Christ offers, as the one who said, "He must increase, but I must decrease" (John 3:30). ${ }^{66}$ Above the desk where he wrote, Barth hung a picture of Matthias Grünewald's Crucifixionfrom the Isenheimer Altarpiece — with the hand of John the Baptist pointing to Christ on the cross. ${ }^{67}$ Barth understood the Bible, and by extension, his work, as pointing-aswitness in a similar manner. ${ }^{68}$

Busch offers this helpful imagery in describing Barth's posture: "In addressing its temporal context, his theology was more like the needle of a compass than a weather

\footnotetext{
64 "Barth in Retirement" TIME (May 31, 1963), 60. Barth added: "a theologian should never be formed by the world around him - either East or West. He should make it his vocation to show both East and West that they can live without a clash. Where the peace of God is proclaimed, there peace on earth is implicit." This article was a follow-up to the cover article on Barth in TIME (April 20, 1962).

${ }^{65}$ Busch, The Great Passion, 31.

${ }^{66}$ All Biblical quotations are from the New Revised Standard Version.

${ }^{67}$ Busch, The Great Passion, 6.

${ }^{68}$ Barth writes, "Think about John the Baptist in the crucifixion scene by Grünewald and the way his pointing hand is twisted in an almost impossible manner. It is this hand that is documented in the Bible" (Karl Barth, The Word of God and Theology, trans. by Amy Marga (New York: T\&T Clark, 2011), 82.
} 
vane. Reflecting on the eternal truth of God, it spoke not from the rocking chair but from the trenches of the church militant. ${ }^{, 69}$ In the liberal theology of his teachers, Barth saw a weather vane, blown by the shifting winds of the era and pointing to where the wind originated. In contrast, Barth understood his role as a witness - as John the Baptist before him — as one that required pointing to the fixed point of God in Jesus Christ. The needle will move as one's position or context changes, but the needle will always point North, to Jesus Christ.

Barth most vividly displayed his commitment to witness by pointing to Jesus Christ amidst trying circumstances during the German Church struggle (Kirchenkampf) in the 1930s. Barth was teaching in Bonn when Hitler came to power. He joined the Confessing Church movement, and famously served as the primary author of the Barmen Declaration in 1934. Barth's refusal to salute Hitler before lecturing in Bonn led to his expulsion from Germany in 1935 . He was immediately offered a chair in systematic theology at the University of Basel where he remained for the rest of his career. Each page of the Church Dogmatics began as a student lecture in Basel that was then revised for publication. After retiring, Barth found the act of writing more strenuous without the constant, repeated, and energizing act of lecturing to students.

Although the circumstances in early twentieth century Europe were in dynamic flux, Barth's context remained distinctly European. Significantly, Barth did not travel outside of Europe before his trip to the United States in 1962 when he was seventy-five years old and had finished teaching and generating new material for his Church Dogmatics. Much earlier, his younger contemporary, Dietrich Bonheoffer, commented on Barth's relatively insular existence. In his diary on March 10, 1928, after spending a

\footnotetext{
${ }^{69}$ Busch, The Great Passion, 14.
} 
month in Barcelona at the age of twenty-two, Bonhoeffer wrote: "My theology is beginning to become humanistic; what does that mean? I wonder if Barth ever lived abroad?",70 Though Barth had lived in Geneva as the assistant pastor of a German Reformed congregation for two years from 1909-1911, traveled to France in 1934, and travelled extensively in Europe in 1938, including the United Kingdom, during the lead up to World War II, Bonhoeffer's instincts were correct. ${ }^{71}$ Barth's theology had been shaped within Europe and predominately within Swiss-German culture. In contrast, Bediako had travelled around Africa, Western Europe, Egypt, India, the United States, Mexico, and Thailand before his fiftieth birthday. Unlike Bediako's thought, then, Barth's theology emerged largely from within a particular cultural worldview that was not disrupted by direct encounters with other cultures.

Yet, Barth's world was by no means static. Central Europe in the early twentieth century, and Germany in particular, experienced tumultuous, dynamic change. Barth's career and writing were defined and shaped by: the social and cultural challenges of German ambition, the harsh terms of the Versailles treaty, the economic deprivations of the 1920s, the rise of National Socialism in the 1930s, the events of the second World

\footnotetext{
${ }^{70}$ Dietrich Bonhoeffer, Barcelona, Berlin, New York: 1928-1931 Dietrich Bonhoeffer Works vol. 8 (Minneapolis: Fortress Press, 2008), 64; according to the editors: "By 'abroad' Bonhoeffer is referring to non-German-speaking cultures." Three days after his diary entry, Bonhoeffer wrote a letter to Walter Dre $\beta$ where he again mused about Barth's hypothetical response to Barcelona: "On Sunday I preached on Romans 11:6 and in the process realized that my previous understanding of dogmatics is being severely questioned by all these new impressions in a country that has known neither war nor revolution, neither a youth movement nor Spengler. It's still difficult to articulate these impressions. In any case I now do have serious questions whether Barth could have written in Spain - whether he had any understanding at all for circumstances outside Germany. At the very least, given the circumstances here-both ecclesiastical and political — one really finds oneself forced to reassess one's theology from the ground up" (Bonhoeffer, Barcelona, Berlin, New York, 76).

${ }^{71}$ Bonhoeffer attributed quite a significant shift in his own theological thinking due to his time abroad. Near the end of his life, he wrote from prison to his friend Eberhard Bethge, "I don't think I have ever changed much, except at the time of my first impressions abroad, and under the first conscious influence of Papa's personality. It was then that a turning from the phraseological to the real ensued." Dietrich Bonhoeffer, Letters and Papers from Prison, Dietrich Bonhoeffer Works vol. 10 (Minneapolis: Fortress Press, 2010), 358.
} 
War, including the Holocaust, and the ensuing Cold War. Barth's break with Protestant liberalism, his public expression of opposition to the theological endorsement of the Great War and his subsequent criticisms of the German Christians, all demonstrate the possibility of a contestation of cultural assumptions in view of God's self-revelation in Jesus Christ. Indeed, where Bediako was constantly trying to justify African Christianity (to the West) as an authentic and independent expression of the revelation of God to African people, Barth was constantly reasserting the primacy of God's self-revelation in Jesus Christ. From radically different starting-points, Barth and Bediako both sought to uncouple the connection between the gospel of Jesus Christ and European culture that had been forged as part of the colonizing project in Africa on the one hand, and essentialized as true religion in Europe on the other.

\section{III. Shared Inheritances}

Though I have identified the socio-cultural and religious contexts of Bediako and Barth as radically different starting-points, their work contributes to an ongoing, worldwide theological conversation. A comparison of these theologians explores two distinct, yet overlapping, approaches to Protestant thought in the twentieth century; Bediako and Barth share a number of common inheritances that inform their work.

Bediako's education shared many common sources and influences with Barth's training in European liberal Protestantism. Most generally, as two theologians working within the Reformed tradition, their writings featured the themes of the sixteenth-century European reformations: sola scriptura, sola gratia, sola fides, and solus Christus. The 
solae of scripture alone, grace alone, faith alone, and Christ alone, played a prominent role in both authors' theologies. And hidden connections in their common theological "ancestors" —as Bediako would put it—can be shown through comparing their shared sources for dialogue partners.

Both authors stress God's movement toward humanity in Jesus Christ and faith as a free gift of grace that cannot be earned. Bediako does so in his widely read text, "Jesus in African Culture: A Ghanaian perspective" (JAC). Barth is known for his unwavering focus on Jesus Christ in his Church Dogmatics. Their shared commitment to Scripture is also evident in the numerous citations of Biblical texts and their in-depth engagement with significant passages. The Gospel of John and the Epistle to the Hebrews are favorite books for both and their interpretations play a prominent role in this dissertation, especially in chapter 4. Indeed, I will argue later that one of the discoveries of this research is that in spite of their radically different starting points religiously and culturally, their theological starting points are not as disparate as one might expect. While the influence of late twentieth-century American evangelicalism certainly shapes Bediako's thought in ways that Barth did not experience and while Barth received a much heavier dose of nineteenth-century European Protestant thought, the theologies of these two authors draw upon enough of the same sources to support and encourage a useful and helpful comparison. Indeed, although making different points and using different language to do so, Bediako and Barth are engaging in a shared conversation about the future of Christian theology. Each is responding to the failings of nineteenth century European Protestantism. Bediako received this legacy through colonialism and is offering a post-colonial theology. Barth received this legacy through his "liberal" teachers steeped 
in modernism and offers an initial "post-modern",72 theology.

\section{A.}

\section{Ancients and Moderns}

Bediako and Barth cited the work of numerous similar authors. In terms of the ancient period, Bediako's Theology and Identity engaged Christian authors from the first three centuries of the Church. Barth, as well, shared a fondness for these patristic sources. In addition to citing significant non-Christian authors - Plato, Aristotle, Cicero, Seneca, Tacitus, and Virgil—Bediako and Barth both employ many of the most significant authors of the period of the early Church. Bediako wrote entire chapters on Clement of Alexandria, Justin Martyr, Tatian, and Tertullian in Theology and Identity; Barth also cited all four at various points in his Church Dogmatics. In addition to these authors that Bediako studied for Theology and Identity, Augustine also looms large for him, particularly his Confessions and the City of God. According to his widow, Bediako wanted to write a book about the City of God, and began reading toward that end, "though his hectic schedule meant that it was always 'on the back burner,' so to speak, and he did not live to take it very far." ${ }^{, 73}$ Similarly, Barth spent significant pages engaging Augustine's views of creation, grace, election, and wrote a short book on Augustine's understanding of the Holy Spirit, The Holy Spirit and the Christian Life (1929). In addition, both men cited other patristic luminaries such as Athanasius, Eusebius, Irenaeus, Origen, Lactantius, and Jerome.

\footnotetext{
${ }^{72}$ I follow William Stacy Johnson in understanding Barth as "postmodern." See William Stacy Johnson, The Mystery of God: Karl Barth and the Postmodern Foundations of Theology (Louisville: Westminster John Knox, 1997), esp. 184-191. Interestingly, this book was one of the few on Barth in the library of the Akrofi-Christaller Institute.

${ }^{73}$ Gillian Mary Bediako, personal email correspondence, 3 June 2013.
} 
Bediako ignored the medieval period and, in fact, spent very little time or space engaging authors after the fifth century until the mid-twentieth century. For example, he does not cite Luther or Calvin in Theology and Identity, Christianity in Africa, or Jesus and the Gospel in Africa. He had read them and did appreciate them as "vernacular theologians" and as "ancestors" of the Basel Mission, who had contributed to the world Church, yet he did not feel the need to address them in his work. ${ }^{74}$ The reason for Bediako's disregard of the magisterial reformers (as well as Enlightenment thinkers) is easy to explain: the theologies of the Reformation were not a direct contributor to African Christianity's dual heritage in pre-Christendom Christian thought and pre-colonial traditional African religions and spirituality. In contrast, Barth paid close attention to the Reformers and Enlightenment authors and themes. He gave a number of lecture courses on John Calvin and Friedrich D.E. Schleiermacher, and often engaged them as well as Immanuel Kant and G.W.F. Hegel in his writings. The most significant common inheritance for Bediako and Barth are the Blumhardts as will be discussed further in the next sub-section.

In the modern period, a wide range of authors constitutes their shared inheritance. From Sigmund Freud, Martin Buber, J.P. Sartre, and Paul Ricoeur to Roman Catholic authors such as Karl Rahner and Yves Congar, Bediako and Barth displayed an array of interests and audiences. Liberal Protestant Adolf von Harnack and Swiss Reformed theologian Emil Brunner are joined with the defender of Biblical inerrancy B.B. Warfield, and twentieth century theologians H. Richard Niebuhr, Lesslie Newbigin, and Jürgen Moltmann; all are cited by both theologians. Although Bediako bypasses Aquinas, Luther, Calvin, and Feuerbach, he cites Jonathan Edwards, a figure who Barth notably

\footnotetext{
${ }^{74}$ Gillian Mary Bediako, personal email correspondence, 3 June 2013.
} 
ignores. Had Barth lived a little later, a number of significant authors who appear in Bediako's work (but published after Barth's death), might also have been shared interlocutors, including Gustavo Gutierrez, Leonardo Boff, James Cone, Desmond Tutu, John Mbiti, Kwesi Dickson, J.S. Pobee, and Bolaji Idowu.

These literary connections indicate that the theological thought of Bediako and Barth share more in common than their diverse contexts might suggest. In spite of their markedly different cultural settings, Bediako and Barth inherited a common corpus of prior interpreters of the Christian faith and scriptures. Yet, they drew on these common sources quite differently due to different aims in their writing. Further, Bediako possessed an intimate knowledge of African Christian writers that Barth lacked, while Barth paid significantly more attention to his theological predecessors and European philosophers that Bediako ignored.

\section{B.}

\section{The Blumhardts}

The most significant shared inheritance for Bediako and Barth was the Blumhardt family of German pietist pastors in the late nineteenth and early twentieth centuries. Section II documented the influence of the Blumhardts' writings on Barth's theological development. The connection to Bediako is not as direct, but very significant nonetheless. In 1815, Johann Christoph Blumhardt, the father of Christoph Blumhardt, founded the Basel Mission. His brother Christian Blumhardt (Christoph's uncle) served as its first Director. This section demonstrates how the beliefs and practices of the Basel Mission formed Bediako's understanding of the Christian faith and the possibilities of the 
encounter between the gospel and African culture.

The Blumhardts were directly involved in the beginning of the Basel Mission's work and a brief recounting of that history demonstrates their lasting influence that affected Bediako. The Basel Mission sent out its very first missionaries to the Gold Coast (modern day Ghana) in 1828. A second group of missionaries, including Andreas Riis, arrived in 1832 to replace the first four missionaries who had all died of sickness. Less than a year later, both of Riis' companions had also died and he was the only one left. $\mathrm{He}$ left the coast and journeyed inland to the Akuapem Hills. The paramount chief (the highest-level political leader in the area), Nana Addo Dankwa I, and his elders warmly accepted Riis. In 1835, Riis decided to move to Akropong because: (1) the climate was healthier; (2) he would be able to work among a truly indigenous people who had not been influenced or affected by the demoralizing life of Europeans at the coast; and (3) working in Akropong, he would be free from the suspicion of being an agent of any colonial power. ${ }^{75}$ Since there was no colonial presence in Akropong, Riis would be free to proclaim the gospel without having the message confused by other Europeans.

Riis gained no converts in Akropong and Nana Addo Dankwa "told Riis that he believes if his people see a dark-skinned person who believes in the God of the white and also reads the Bible, it would go a long way to change their perception about Christianity. ${ }^{, 76}$ When Riis returned to Europe for a furlough, he shared Dankwa's comments with the Basel Mission who then made the decision to recruit missionaries from Jamaica to send to Akropong. In 1843, "six families and three bachelors arrived...It was their presence that changed the face of the mission work in Akropong and for that

\footnotetext{
${ }^{75}$ Christ Presbyterian Church, Akropong-Akuapem, Ghana website, "History," http://www.akropongcpc.faithweb.com/history.htm, accessed January 31, 2014. ${ }^{76}$ Ibid.
} 
matter the country as a whole."77 World War I interrupted the work of the Basel Mission as the British authorities in the Gold Coast removed anyone with any connection to Germany. The Basel Mission was replaced by the Church of Scotland, leading to the fascinating pastiche that is the Presbyterian Church of Ghana (PCG) today-a denomination rooted in traditional African religion, started by German Pietists, and organized by Scottish Presbyterians. ${ }^{78}$ In 2012, the PCG had more than 565,600 members and almost 2,200 congregations and was one of the largest denominations of the historic mission churches in Ghana along with Methodists and Roman Catholics. ${ }^{79}$ AkropongAkuapem, in the then-Gold Coast, became the center of the Presbyterian Church of Ghana - the denomination that ordained Bediako for ministry — and later the site for his founding of the Akrofi-Christaller Institute for Theology, Mission, and Culture.

This dual connection to the influence of the Blumhardts highlights the two sides of the colonial divide that Bediako and Barth inhabited. Barth read and knew the Blumhardts directly while Bediako indirectly received the impact of the Blumhardts' thought through colonial missionary structures and others who knew them. Bediako's sole quotation of the Blumhardts appears in an unpublished lecture on education. Given the significance of the colonial overtones, and of the Blumhardts to Barth, I quote Bediako in full here:

The instructions to the first missionaries sent by the Basel Mission to Ghana (the Gold Coast) in 1827 struck a similar note. The first Director of the Basel Mission, Christian Blumhardt, told them that [the] mission was to make:

\footnotetext{
77 Ibid.

${ }^{78}$ For more on the founding and history of the Presbyterian Church of Ghana, see Noel Smith, The Presbyterian Church of Ghana, 1835-1960: A Younger Church in a Changing Society (Accra: Ghana Universities Press, 1966).

${ }^{79}$ World Council of Churches, http://www.oikoumene.org/en/member-churches/presbyterian-church-ofghana, accessed January 31, 2014.
} 
reparation (Wiedergutmachung) for injustice committed by Europeans, so that to some extent the thousand bleeding wounds could be healed which were caused by the Europeans since centuries through their most dirty greediness and most cruel deceitfulness.

Such expressed motivations by no means excuse the attitude of European cultural superiority which even some missionaries would demonstrate. Nevertheless, they help to explain some of the distinctive elements of the Christian ideal and content of education as practised in our country. ${ }^{80}$

Blumhardt's words indicate an awareness of the Basel Mission, already in 1827, toward the injustices committed by Europeans through their "dirty greed" and "cruel deceit." The Basel Mission sought to offer a version of Christianity not based on colonial assumptions, but in reaction to them and in response to the theology of the Blumhardts. The hope of Christian Blumhardt was that this "better" Christianity could serve as "reparation" for past wounds. This revised understanding of Christianity offered an alternative within nineteenth-century European Protestantism. Christian Blumhardt's intent was reflected in concrete differences in missionary practice in Africa.

The Basel Mission's approach to education was a significant difference. In the areas of Ghana influenced by the Basel mission, schools placed a strong weight on education in African mother-tongues. ${ }^{81}$ This emphasis included an emphasis on the grammar of mother-tongues, not simply the use of the languages, in contrast to the

\footnotetext{
${ }^{80}$ Kwame Bediako, "An Evaluation of the Achievement of the Christian Ideal in Education in Ghana from the 19th century to the early 20th century," in Educating a Nation-A Christian perspective for our time, the Andrew McCutcheon Atkinson Memorial Lectures delivered at the Presbyterian Church of the Resurrection, Accra, Ghana, 1 December 1993, unpublished, 2. Bediako was quoting from Karl Rennstich, "The understanding of Mission, Civilisation and Colonialism in the Basel Mission," in Missionary Ideologies in the Imperialist Era: 1880-1920, ed. by Torben Christensen \& William R. Hutchinson (Copenhagen: Aros, 1982), 95. Rennstich, in turn, was quoting Christian Blumhardt, "Die 'Instruction"” Evangelisches Missionsmagazin [EMM] (1830): 451-82; specifically pages 454, 468, 470, 472, 480, and 481.

${ }^{81}$ Bediako, "Achievement of the Christian Ideal in Education in Ghana," Lecture 3, 5-6.
} 
mission-led schools founded by the Methodists (such as The Mfantsipim school, founded in 1876, that Bediako attended). The conviction of the Basel Mission to encourage the use of the mother-tongues was demonstrated by their commissioning in 1853 of the German Johannes Gottlieb Christaller (1827-1895) "to devote himself solely to the Twi language, the most widely-spoken in the Gold Coast." ${ }^{82}$ Christaller had translated the entire Bible into Twi by 1862 . His translation was published in $1870-71$, a comprehensive grammar in 1875 , and a monumental dictionary in $1881 .{ }^{83}$ Christaller has been widely revered for his work (CiA, 78-81). The late Ghanaian philosopher J.B. Danquah even referred to Christaller (a white European) as "an ancestor." ${ }^{\text {" }}$ Danquah offered the following evaluation of Christaller's work,

but for Christaller's foresight in recording in permanent form the scattered elements of the beliefs, hopes and fears of the Akan people at this particular juncture...the Akan people of the Gold Coast in West Africa would have failed to bring their indigenous contribution to the spiritual achievements of mankind. ${ }^{85}$

Christaller was commissioned by the Basel Mission and embodied its spirit. The same nineteenth-century German pietism that influenced Barth through the Blumhardts, allowed the Akan people to "bring their indigenous contribution to the spiritual achievements" 86 of humankind. Christaller's work formed the basis for the first modern Twi Bible, produced by Ghanaian Clement A. Akrofi (1901-1967) in 1965. When the

\footnotetext{
${ }^{82}$ Smith, Presbyterian Church of Ghana, 54.

${ }^{83}$ J. G. Christaller, A Grammar of the Asante and Fante Language Called Tshi Based On the Akuapem Dialect with Reference to the Other (Akan and Fante) Dialects (Basel: Printed for the Basel evang. missionary society, 1875) and J. G. Christaller, A Dictionary of the Asante and Fante Language Called Tshi (chwee, Twi): with a Grammatical Introduction and Appendices On the Geography of the Gold Coast and Other Subjects (Basel: printed for the Evangelical Missionary Society, 1881).

${ }^{84}$ J.B. Danquah, The Akan Doctrine of God: A Fragment of Gold Coast Ethics and Religion (New York: Routledge, 2006, second edition, 1968 [1944]), 185. Quoted in Bediako, CiA, 79.

${ }^{85}$ Danquah, The Akan Doctrine of God, 186. Quoted in CiA, 79; and Smith, Presbyterian Church of Ghana, 55.

${ }^{86}$ Danquah, The Akan Doctrine of God, 186.
} 
Bediakos founded their research institute in Akropong-Akuapem—where Andreas Riis had moved in 1835-they named it the "Akrofi-Christaller Mission Centre" in tribute to these two scholars of the Twi language, Bible translators, and pioneer figures in the cultural witness of the Church in Ghana.

Bediako - as an indigenous African theologian — is, in some ways, a direct descendent of these pioneering efforts of the Basel Mission in the Gold Coast (Ghana). Bediako constructed his African Christian theology upon the foundation of Christaller's and Akrofi's work translating the Bible into an African mother-tongue, Twi. Bediako's underlying theological conviction, the infinite translatability of the gospel of Jesus Christ, arises from the translation of the Christian scriptures into African languages and vernacular theological concepts. In this way, he continued the Blumhardt's legacy and the work of the Basel Mission.

\section{IV. Mutual Suspicion}

The Basel Mission's affirmation of African languages and cultural concepts was unusual among late nineteenth-century Protestants. Within religious thought, many colonial missionaries leveled chauvinistic criticisms against Africans. At the Edinburgh conference in 1910, traditional African religions were seen to be false figments of the imagination and/or expressions of the work of the devil. ${ }^{87}$ The vast majority of European

\footnotetext{
${ }^{87}$ Of particular note is the final chapter of the Commission IV report. For more on this significant moment in missionary history and the delimiting of Christendom, see Brian Stanley, The World Missionary Conference, Edinburgh 1910 (Grand Rapids: Eerdmans, 2009), esp. 235-245. See also Bediako's assessment: "The missionary enterprise of the nineteenth century did not see in African traditional religion and culture a partner for dialogue the way in which it viewed Buddhism and philosophical Hinduism in Asia" (CiA, 69).
} 
missionaries to Africa in the late nineteenth and early twentieth centuries viewed it as the "dark continent," devoid of religious goodness. Such a dualistic style of thought that typified the entire colonial project — one that oppressed Africans through the use of dichotomies — proved deeply damaging for both the colonized and the colonizers. ${ }^{88}$ The colonial mindset that viewed Africans as unintelligent, irreligious objects of colonial missions, including its manifestations in theological circles, led, in part, to many Africans' suspicions of Europeans and European thought.

Bediako was no exception. For him, the mistrust of Western theology ran very deep. Much of his antipathy towards Western thought stems from two sources: the colonial legacy and French existentialism. Although Bediako was grateful to European missionaries for translating the Bible into African languages (mother-tongues) and bringing the name of Jesus Christ to Africa (CiA, 185, 203), in his own experience, Europe brought atheism to him through his exposure to existentialists such as Jean-Paul Sartre. As will be explored in more detail in chapter 2, Bediako understood his conversion to Christianity as a return to his Africanness and a turn away from Europe. While Bediako's work does not especially evidence anger toward Europe, he was wellread in the authors of négritude—particularly, Léopold Senghor and Aimé Césairewhose writings harshly rejected colonial rule and European hegemony while articulating a vision of "blackness." Bediako, an African whose ancestors had not been taken as slaves, found Senghor's vision of a recovery of the black African past to be more compelling than Césaire's longing for a history that had been cut off in the Middle

\footnotetext{
${ }^{88}$ Frantz Fanon, Black Skin, White Masks (New York: Grove Press, 2008 [1967]), 160. Fanon describes the dualistic structures of colonialism as a Manichaean world: "first and foremost, stating the principle 'It's them or us' is not a paradox since colonialism, as we have seen, is precisely the organization of a Manichaean world, of a compartmentalized world." Fanon, Wretched of the Earth, 43.
} 
Passage. Bediako's work was a post-colonial project articulating an African Christian identity through the recovery of the pre-colonial African religious past.

As Africans began to convert to Christianity, the African versions of their Christian practices, especially worship practices, were never pure enough. African Christians have been often criticized as syncretists—-for combining the gospel with African cultural forms. As we will see, these same critics ignored, or better yet, were blind to, evidence of syncretism in the West. Bediako's work demonstrated awareness that the concept of a "pure gospel" is a Western cultural myth that has detrimental effects - both on Africans and Westerners. The question of syncretism will be explored more fully at the end of chapter 4 .

Bediako was extremely familiar with Western thought, so much so that Adrian Hastings, a renowned historian of the Christian church in Africa, referred to Bediako as “intellectually a Scot, as well as an Akan" following Bediako's years of study at the University of Aberdeen ${ }^{89}$ Bediako's work was in large part a justification of African Christianity to Westerners. For him, the criteria and means of this justification to Western audiences were very significant. He adopted the language (first used by Barrett and Walls) of the shift of the "centre of gravity" within Christianity. Walls wrote, within the last century there has been a massive southward shift of the center of gravity of the Christian world, so that the representative Christian lands now appear to be in Latin America, sub-Saharan Africa, and other parts of the southern continents. This means that Third World theology is now likely to be the representative Christian theology. ${ }^{90}$

\footnotetext{
${ }^{89}$ In Hastings' view, "the interplay of the two is what makes his work so exciting." Adrian Hastings, "A New Voice out of Ghana: A Review of Kwame Bediako's Christianity in Africa" The Church Times (January 1996): 15. See also Adrian Hastings, The Church In Africa: 1450-1950 (Oxford: Clarendon Press, 1994) and Adrian Hastings, A History of African Christianity, 1950-1975 (Cambridge: Cambridge University Press, 1979).

${ }^{90}$ Andrew Walls, "The Gospel as Prisoner and Liberator of Culture," 9-10.
} 
Walls continued, noting that while the "theology of European Christians" may remain important to them, it will, in the not-so-distant future, likely only become of interest to historians, not to theologians or to Christians with more general interests. ${ }^{91}$ Future theologians will be much more interested in works composed in the developing world. Bediako was grateful for this shift from the North to the South as he sees it preserving the Christian faith that has come under threat in Europe. Bediako wrote, "the present shift in the centre of gravity may have secured for Christianity a future that would otherwise be precarious in the secularized cultural environment of the modern West.. ${ }^{92}$ The trajectory of nineteenth century European Protestantism reached its nadir in the crises of the twentieth century, increasing secularization, and decreasing participation in Christian churches. Bediako sees new possibilities for Christianity arising from Africa.

Through an emphasis on the role of the primal imagination and African mother tongues, Bediako pushed for the re-making of Christian theology. Continually, Bediako insisted that Christianity is indigenous to Africa, not imported from Europe. Expressions of Christianity in Africa—in both practices and beliefs- - had significant contributions to make to the worldwide understanding of the Christian faith. The growth of Christianity in Africa, then, was about faithfulness to the gospel, not about power, contrary to Jenkins' assertions in The Next Christendom. Bediako challenged Jenkins' understanding of the nature of the Christian faith when he wrote,

Universal in principle from its origins, Christianity is now for the first time seen as universal in history. And with recession from Christianity occurring in the North at the same time as accession to Christianity in the South, Christianity can be seen as having no one permanent centre. Every

\footnotetext{
${ }^{91}$ Walls, "The Gospel as Prisoner and Liberator of Culture," 10.

${ }^{92}$ Kwame Bediako, "'In the Bible...Africa walks on familiar ground.': Why the World needs Africa" AICMAR Bulletin 6 (2007): 38.
} 
centre is a potential periphery and every periphery a potential centre. ${ }^{93}$

Appealing to the growing presence of Christians in all parts of the world, Bediako used the familiar trope of center-and-periphery from postcolonial theory to demonstrate that Jenkins' understanding of Christianity is still bound by colonial categories. In response to the crumbling, former center of Christianity in Europe, Jenkins sought a new center in the global South. Bediako resisted the guiding assumption of Jenkins' argument. Simply put, Christianity does not require a single center in the global North or the global South. Everywhere Christianity is found is a center of theological reflection and a peripheral recipient of the ongoing theological reflection in every other center.

Bediako viewed any theology that he believed to be based on the imperializing and totalizing claims of Christendom as flawed; Barth's theology, on his reckoning, fit this description as captive to Western assumptions and categories. Bediako did study some of Barth writings while at London Bible College. In a course on "Modern Theology" taught by Richard Sturch in 1975-1976, Bediako read excerpts from Church Dogmatics I and II. ${ }^{94}$ (There is no evidence that Bediako ever read any of Barth's Doctrine of Reconciliation, Church Dogmatics IV, including the subject of chapter 3, IV.3, §69.) When asked why Bediako did not read Barth, his widow, Gillian Mary Bediako, replied tautologically: "Western theology is Western theology." ${ }^{95}$ Still more specifically, Bediako's view of Barth seems to fit within the well-rehearsed critique of Barth's theology as too transcendent and other-worldly with no points of connection with

\footnotetext{
93 Bediako, "Why has the summer ended and we are not saved?," 5-6.

${ }^{94}$ Richard Sturch, personal email correspondence, 7 November 2012. Sturch's best-known publication is: Richard Sturch, The Word and the Christ: An Essay in Analytic Christology (Clarendon Press: Oxford, 1991).

${ }^{95}$ Gillian Mary Bediako, personal interview, June 1, 2012, Akrofi-Christaller Institute, AkropongAkuapem, Ghana.
} 
everyday human life, particularly the lives of Africans. Gillian Mary Bediako reported that her late husband understood Barth as interested in "addressing the particular and peculiar phenomenon of a West that was departing increasingly from its primal rooting and Christian heritage." ${ }^{96}$ Bediako believed, more basically, that all Christian theology needed to be re-made; Western theology was too deeply flawed to be rescued.

One significant flaw in Western theology was perceptions about race, particularly non-white peoples. While working on his doctorate in Aberdeen - if not before-Bediako became familiar with Barth's comments about Ghanaian theologian C.G. Baëta. ${ }^{97}$ After Barth met Baëta and his wife in 1951, he described them in a letter to his son as "kohlrabenschwarz, aber mir sehr sympathisch," translated as "both coal black, but I got on with them very well." 98 While not necessarily a racist term, Barth's use of the descriptor, "coal black," (and the conjunction aber, "but") displays an obvious cultural insensitivity. This comment, when he read it, was enough for Bediako to cast Barth's writings into the same heap with the rest of Western theology. ${ }^{99}$ In contrast, Bediako focused on the theological and spiritual needs of his fellow Africans; an interest that Barth did not share.

Barth only mentioned Africa twenty times in his Church Dogmatics. Most of these uses either referred to missionaries, or to Africa as an object of missionary outreach. Having died before Bediako published any work, Barth could not engage him,

\footnotetext{
${ }^{96}$ Gillian Mary Bediako, personal email correspondence, 3 June 2013.

${ }^{97}$ Robert Aboagye-Mensah, personal email correspondence, 7 June 2012. A fellow Ghanaian, AboagyeMensah wrote his $\mathrm{PhD}$ dissertation on Barth at the University of Aberdeen while Bediako was there. See Robert Aboagye-Mensah, "Socio-Political Thinking of Karl Barth: Trinitarian and Incarnational Christology as the Ground for his Social Action and its implications for us today" (PhD dissertation, University of Aberdeen, 1984).

${ }^{98}$ Quoted in Eberhard Busch, Karl Barths Lebenslauf: Nach Seinen Briefen und Autobiograph Texten (München: Kaiser, 1975), 410; ET: 396; from a letter from Karl Barth to Christoph Barth, 25 August 1951.

${ }^{99}$ Robert Aboagye-Mensah, personal email correspondence, 7 June 2012.
} 
but, as was noted earlier, neither did he address any twentieth century African theologians. He did not seem to consider the possibility that modern African theology could be a rich source for theological reflection. Africa was a destination for missionaries, and a difficult one at that. At the turn of the twentieth century, anthropologists were just returning to Europe from other parts of the world with accounts of the religious practices and beliefs they encountered. (Émile Durkheim's The Elementary Forms of Religious Life was first published in 1912.) At this time, Africa and Asia were seen mostly as destinations for missionaries and sources of raw data for Western theories of religion. The peoples of these lands were not seen as conversation partners in theological discussions; they were to be consumers of theology, not producers in the field of Christian thought.

However, towards the end of his life, Barth offered two glimpses of a contrary, developing view—-perhaps non-Westerners, and particularly non-Europeans, may have significant contributions to offer to Christian theological reflection. In his 1963 address to foreign students in Basel, most of whom were from Africa, Asia, and Latin America, Barth concluded by saying that "The day may come when [Christianity] will be better understood and better lived in Asia and Africa than in our old Europe. Meanwhile try to learn, not from us, but with us, that the horizon and hope of us all also includes this: that God is for us and with us." ${ }^{100}$ Further, just three weeks before his death in 1968, Barth wrote a letter to "Southeast Asian Christians" in which he encouraged them to do theology for themselves. He wrote,

In my long life I have spoken many words. But now they are spoken. Now it is your turn. Now it is your task to be Christian theologians in your new, different and special situation with heart and head, with mouth and

\footnotetext{
${ }^{100}$ Karl Barth, “Christianity or Religion?” in Fragments Grave and Gay (London: Fontana, 1971), 30-31.
} 
hands...You truly do not need to become 'European,' 'Western' men, not to mention 'Barthians,' in order to be good Christians and theologians.

You may feel free to be South East Asian Christians. Be it! ${ }^{101}$

Even though Barth did not offer sustained attention to the theological developments taking place in Africa or Asia, his earlier suspicions - or at the least omissions-lessened as he acknowledged that the future of Christian theology may lie in these lands. Bediako represents an expression of that future.

\section{V.}

\section{Three Themes: Revelation, Religion, and Culture}

A comprehensive analysis of Bediako's corpus uncovers three major themes in his work: revelation, religion, and culture. Barth addresses these three themes in close proximity in his mature Christology in Church Dogmatics IV.3, §69. The compelling nature of this comparison is the way that these two authors from different religious and cultural starting points use similar theological assumptions to address the same themes. I will also show that this comparison offers insight into the complex character of Christian theological reflection and the vexed issue of world Christianity(-ies) today.

Through their writings, Bediako and Barth each demonstrated a similar assumption: a determined and dogged concentration on the person of Jesus Christ. More than an abstract notion of God in general or of God as Father or God as Spirit, the second person of the Godhead, Jesus Christ-Immanuel, God-with-us - offers the basis and the content for their theological reflection. Both theologians also turn to the Scriptures of the Old and New Testaments as their authority for learning who Jesus Christ is, what Christ

\footnotetext{
${ }^{101}$ Karl Barth, “No Boring Theology!: A Letter from Karl Barth,” South East Asian Journal of Theology 11 (Autumn 1969), 4-5.
} 
has done, and how to interpret events in the contemporary world. Bediako's first major scholarly publication, "Biblical Christologies in the Two-thirds world," is deeply Christological and lays out the significant themes of his life's work. ${ }^{102}$ Barth's Epistle to the Romans accomplishes a similar task. This common Christological beginning defined their respective understandings of revelation and was maintained throughout their engagements with religion and culture.

Questions about revelation animated the work of both theologians as they each considered in what ways God has spoken to humanity in the past and how God continues to reveal who God is today. Primarily for Bediako, his work sought to counter two misconceptions of European missionaries: (1) that Europeans brought God to Africa, and (2) that there was nothing good in traditional African religions. Primarily for Barth, his work sought to counter what he took to be the misleading impact of "culture Protestantism" (Kulturprotestantismus) upon the task of theology. This reorientation of Barth's thought began through his study of the Bible, particularly Romans; his opposition to culture-Protestantism was then demonstrated in particular moments of protest, including against theologians endorsing Kaiser Wilhelm I's war effort, and the German Christians' cooperation with Adolf Hitler and the Nazi party. Such instances disturbed Barth due to their claims that asserted human reasoning over against God's selfrevelation. These movements in Germany shared with colonial officials in Africa overconfidence in the human interpretation and application of revelation over against, or in addition to, God's self-revelation in Jesus Christ.

This shared focus on the person and work of Jesus Christ also leads both

\footnotetext{
${ }^{102}$ Kwame Bediako, "Biblical Christologies in the context of African Traditional Religion" in Sharing Jesus in the Two-Thirds World, eds. Vinay Samuel and Chris Sugden (Grand Rapids: Eerdmans, 1984).
} 
theologians to ask questions about the nature of religion: What is true religion and in what ways can Christianity be a "true religion"? For Bediako, Christianity can be the true religion when the Christian faith is separated from Western cultural interpretations and focused on Jesus Christ. This expression of the Christian faith is indigenous to Africa and is authentic to the African context. For Barth, the Christian faith consists in living in correspondence to the work of God in Jesus Christ that has already been completed and accomplished on behalf of all humanity. Christianity, then, cannot be based on abstract principles, or merely the name of Jesus Christ, but only upon the concrete history of the person of Jesus Christ.

The expression of God in human flesh, the Incarnation of the second person of the Trinity in Jesus Christ, is deeply significant for both authors. In the Incarnation, God's revelation takes human, bodily, cultural form. God uses materiality for the purpose of God's self-revelation. In short, for both authors, culture matters. That is, cultureunderstood both as material culture, i.e. created things, and nonmaterial culture, i.e. stories, myths, religions — can be and is used by God to reveal to humanity who God is. For Bediako, the Incarnation is the theological foundation for the translation of the gospel into human cultures through the use of vernacular and mother-tongue African languages. Translatability becomes, in Bediako's words, "the hermeneutical key” for interpreting Scripture (TI, xvi and 426). For Barth, the incarnation is the material content of volume IV of Church Dogmatics: The Doctrine of Reconciliation, specifically "The Way of the Son of God in the Far Country," $\$ 59.1$ in IV.1 and "The Homecoming of the Son of Man" in $§ 64.2$ in IV.2. The incarnation is the constituting event of the God-man himself whose glory as mediator and significance as prophet are explored in IV.3, §69-the topic 
of chapter 3.

In spite of other interesting topics for a comparison-most notably on creation, providence, and election - the comparison focuses on the themes of revelation, religion, and culture that recur throughout Bediako's writings and are treated by Barth in IV.3, $\S 69$. These three themes will thus be addressed in each succeeding chapter.

\section{VI.}

\section{The Shape of the Argument}

Developing claims outlined in this opening chapter, chapter Two offers a comprehensive analysis of Bediako's work. As will become clear, the question of an African Christian identity dominates Bediako's earliest writings and never disappeared from his work. From Bediako's perspective, the reflections on identity were necessary for Africans prior to more systematic theological writings: If Africans do not know who they are, how could they know what they believe? More generally, this chapter draws out a claim that I take to begin in Bediako's first book, Theology and Identity, and runs through the rest of his writings. Bediako's work is a concerted attempt to understand the universal revelation of Jesus Christ in the translatability of the gospel into all cultures, the continuity of Christianity with traditional African religions, and the indigenous primal imagination as the substructure of African Christianity (as collectively expressed in his ancestor Christology), with implications for engaging religious pluralism, understanding Christianity as a non-Western religion, and the emergence of a world Christianity.

Chapter Three interprets Barth's explication of Christ as universal prophet in Church Dogmatics IV/3, §69—“"The Glory of the Mediator.” Specifically, I argue that 
Barth's understanding of Christ's ongoing prophetic activity intersects with the three theological concerns expressed by Bediako by 1) enabling universal revelation for all, 2) pervading culture (through parables of the Kingdom of Heaven), and 3) redefining religion in ways that recast claims advanced in Church Dogmatics I.2, §17—“On the Sublimation of Religion." Barth uses the office of Christ as prophet to "think together" (zugleich denken) the person of Christ, as divine and human, and the work of Christ in justification and sanctification—while simultaneously re-visiting, and perhaps revising, his understanding of God's self-revelation. This chapter reads Barth's view that "Reconciliation is also revelation" (IV.3, 38/40) as enabling him to hear Christ's "true words" through contemporary "parables of the Kingdom" in such as way as to, quite unintentionally, anticipate postcolonial concerns by rejecting binaries, destabilizing religious power structures, and expanding the possibilities for theological reflection. Christ's prophecy proclaims the reconciliation that his work has achieved. Barth's articulation of Jesus as Prophet in $§ 69$, particularly his "universal prophecy” (IV.3, 50/53) presents a more robust understanding of God's self-revelation while maintaining a consistent understanding of religion. Christ not only speaks to all people universally, but can also speak in any and all ways. Barth's discussion of "parables of the kingdom" offers the surety that Christ's "voice will also be heard without" the Church or the Bible (IV.3, 117/130-131). The self-communication of God is not limited by scope or means. Through the presence of Christ, "true words" are spoken to the Christian community through a variety of media. Thus, Barth's understanding of the 'Light of Life' (Barth's

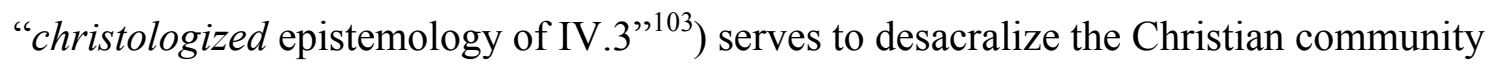

\footnotetext{
${ }^{103}$ Paul Dafydd Jones, The Humanity of Christ: Christology in Karl Barth's Church Dogmatics (New York: T\&T Clark, 2008), 252.
} 
and the Biblical Scriptures and collapses the categories of "sacred" and "profane." Eliminating this binary categorization opens the possibility of affirming traditional African religions as media of revelation.

Chapter Four places the theology of Kwame Bediako, shaped against the infiltration of African religious life by Christian European missionaries who were part of nineteenth-century colonization, in dialogue with the theology of Karl Barth, as expressed primarily in his Church Dogmatics IV.3, that was shaped by a life-long struggle to appropriately distinguish between Christianity and religion. This chapter draws upon both authors' distinct Christological theologies to consider Christ's universality and their theological interpretations of the Epistle to the Hebrews, before examining the three themes of revelation (comparing Bediako's use of the concept of translatability to Barth's use of the imagery of light), religion (comparing their respective understandings of religion as projection), and culture (through an exploration of how their thought shapes differing universalisms), and it culminates with an analysis of the question, "Are we all syncretists?" that draws on prior interpretations.

The concluding chapter 5 consolidates insights on the themes of revelation, religion, and culture, before expanding the frame to demonstrate the relevance of the comparison and the three themes to contemporary theological developments in the U.S. and abroad. 


\section{Chapter 2 \\ Kwame Bediako: An Act of Theological Négritude}

Christianity itself has emerged historically as part of the cultural impact of the West on the rest of the world...we ought to dissociate the Christian Gospel from the trappings of western culture. But the interrelation of Gospel and human culture is a complex one; the Gospel can only be perceived by us in some cultural form or other-a pure Gospel devoid of cultural embodiment is simply imaginary. The trouble is that we all wear cultural blinkers, and whilst we may affirm an absolute Gospel and accept the relativity of our diverse cultures, each of us fails to perceive some important facets of the one Gospel. - Kwame Bediako ${ }^{1}$

The themes of revelation, religion, and culture pervade Kwame Bediako's corpus. Based on a comprehensive analysis of Bediako's work, this chapter argues in a cumulative manner that his pursuit of questions of identity - first as an African and then as an African Christian - leads him to discover the twin heritage of African Christianity. Through a repeated emphasis on the infinite translatability of the gospel of Jesus Christ, Bediako advances an understanding of revelation that accentuates the direct communication of the gospel to Africans, and claims that Christian faith is continuous with traditional African religious practices. Further, based on his conviction of the indigenous character of Christianity within Africa, Africans are to translate the gospel into vernacular cultural forms and concepts - building upon the primal imagination as the substructure of African Christianity.

The category of religion often functions for Bediako as a description of the "cultural blinkers," or blinders, that humans bring to their understanding of God. He criticizes western Christian theology — and its legacy of colonialism in particular-for its

\footnotetext{
${ }^{1}$ Kwame Bediako, "The Willowbank Consultation, January 1978—a personal reflection," Themelios 5:2 (Jan. 1980): 28; emphasis added.
} 
overconfidence in revelation the he sees as all-too-synonymous with Western culture. On the other hand, African traditional religions (ATRs), in Bediako's view, can also blind adherents to God's complete revelation that comes through the name of Jesus Christ and the scriptures of the Old and New Testaments. The remarkably consistent argument of Bediako's work is that Africans must recover their history, as Christians and as Africans, in order to shape and articulate an African Christian identity. In doing so, Bediako believes that Africa may save Christianity itself through the remaking of Christian theology.

In Bediako's earliest published writings, he articulates the challenges of African Christians seeking to shape an African Christian identity. His very first publication questions the exportability of Western theology: "If much of the theological effort in the non-western world merely reproduces replays of the original western versions, we must ask ourselves whether the Christianity that was planted was such as would allow emerging Christian thinkers to answer their own questions." Already, Bediako is asserting the need for Africans to think for themselves and not to allow the dominant Western thought patterns to go uncriticized. The epigraph above comes from his third publication and contains a virtual précis of his entire career. He is convinced that God is always "addressing himself to the questionings and longing of [non-Western] minds and hearts in the concrete realities of their environments." ${ }^{3}$ Here we see the active God of Bediako's faith, a God who directly addresses the concerns of non-Western peoples in their specific context. This is an important determination that holds together various claims. Against a critic of contextualizing Christian theology, Bediako responded with

\footnotetext{
${ }^{2}$ Kwame Bediako, "Response to Taber: Is there more than one way to do theology?" Gospel in Context 1:1 (1978): 13-14.

${ }^{3}$ Bediako, "Response to Taber," 14.
} 
characteristic boldness: “the answer to 'false contextualization' is not no contextualization, but faithful contextualization." ${ }^{4}$ The proclamation of God in revelation comes to humanity in cultural embodiment—an embodiment that is necessarily unavoidable, yet while revealing, its "cultural blinkers" also obscures. This chapter examines Bediako's understanding of "faithful contextualization": what it means, how it occurs, and what its implications are for Christian theological reflection. It demonstrates that "faithful contextualization," for Bediako, involves receiving God's revelation in and through African religions and culture as well as through the Biblical scriptures.

For Bediako, the gospel must be contextualized, but not to the point where its distinctiveness is lost to the host culture, or context. The idea of a "pure Gospel devoid of cultural embodiment is simply imaginary." ${ }^{, 5}$ Or, at least, no human being can encounter such a "pure gospel" without any "cultural blinkers." So, on the one hand, purity is not the goal, or even a possibility, for the Church's understanding of the gospel. On the other hand, the gospel must not be so fused to its host culture that the "blinkers" obscure the distinctiveness of the gospel. Although he never expresses it directly, Bediako is convinced that Western Christianity is not faithful to the gospel, but is actually a projection of Western culture.

Bediako's work suggests, one might say, an equation for the production of theology: Gospel + Culture $=$ Theology. Yet, in this equation, neither "gospel" nor "culture" is an independent variable; rather they exist in a dialectical tension. "Gospel" cannot be apprehended apart from "culture" and "culture" cannot be understood apart

\footnotetext{
${ }^{4}$ Kwame Bediako, “[Response to] David Hesselgrave: dialogue on contextualization continuum.” Gospel in Context 2:3 (1979): 13.

${ }^{5}$ Bediako, "The Willowbank Consultation," 28.
} 
from "gospel." And throughout his work, two themes pervade: identity and integration (for Bediako, a better term than indigenization). These themes first appear in the title of his dissertation, Identity and Integration: An Enquiry into the Nature and Problems of Theological Indigenization in Selected Early Hellenistic and Modern African Christian Writers and never disappear from his concerns. ${ }^{6}$ "The argument of the thesis," Bediako wrote, "attempts to validate the claim that theology is called to deal always with culturally-rooted questions" (TI, Xv).

This chapter's first section pursues Bediako's questions of identity. It opens by demonstrating the influence of négritude upon Bediako's thought through an analysis of his graduate work in Francophone literature that begins with his personal, spiritual, and intellectual questions of identity. This assessment of Bediako's pre-theological workshis unpublished masters and doctoral theses at the Universite Bordeaux III—is essential for an adequate understanding of Bediako's theological motivations and contributions. Bediako's own act of theological négritude identified a past for African Christians that he used to articulate an African Christian identity. The second section explores the theological consequences for revelation, religion, and culture of Bediako's belief that there is a direct connection between Africans and God in Jesus Christ. The third section analyzes the interrelation of these three themes in his theology of the ancestors. The final section notes implications of Bediako's thought for religious pluralism, the remaking of Christianity as a non-Western religion, and the complexities of world Christianity.

\footnotetext{
${ }^{6}$ Bediako defended his dissertation in July 1983. The dissertation was 536 pages, not including the bibliography, and was later published in 1992 as Theology and Identity. Abbreviated as TI.
} 


\section{I. Questions of Identity}

Before engaging Bediako's French works, it is good to pause and define "négritude.” The term was coined by three men: Aimé Césaire (1913-2008), from Martinique in the East Indies; Léopold Senghor (1906-2001), later President of Senegal; and Léon-Gontran Damas (1912-1978), of French Guiana; while editing their newspaper, L'Etudiant noir (The Black Student), in Paris in the mid-1930s. The first use of "négritude" in print appeared in 1939 in Césaire's Notebook of a Return to the Native

Land. ${ }^{7}$ Its origin derives from the French nègre. The term is a

neologism, it is made up (perhaps on the model of the South American negrismo) by latinizing the derogatory word for a black ("nègre") and adding a suffix for abstract nouns (latitude, solitude, exactitude, etc.). It signified a response to the centuries-old problem of the alienated position of black in history, and implicitly called upon blacks to reject assimilation and cultivate consciousness of their own racial qualities and heritage. For Césaire, identity in suffering, not genetic material, determined the bond among black people of different origins. ${ }^{8}$

\footnotetext{
${ }^{7}$ There are seven uses (on five pages) of the neologism "négritude" in the Cahier. See pages 91 (15), 107 (29), 115 (35), 127 (45), and 129 (47) in French edition (English edition). Aimé Césaire, Notebook of a Return to My Native Land = Cahier D'un Retour Au Pays Natal, trans. Mireille Rosello and Annie Pritchard (Newcastle upon Tyne, England: Bloodaxe Books, 1995).

${ }^{8}$ Also, "To consider négritude also brings up the problems in translating the word "nègre" when it occurs in the Notebook. Put briefly, the lexical background is as follows: Before the Second World War the French had three words to designate individuals or things belonging to the black race. The most euphemistic was "Noir" (noun or adjective). The derogatory was "négro." In between, on a sort of neutral and objective ground, was the word "nègre," used both as an adjective (as in "l'art nègre"). For the general public, "noir" and "nègre" may very well have been interchangeable, but the civilized and very complexed Antilleans considered themselves as "Noirs," the "nègres" being on that distant continent, Africa. And it is in this light that one must read Césaire's use of the word "nègre" and its derivatives, "négritude," "négrillion," and "négraille": he was making up a family of words based on what he considered to be the most insulting way to refer to a black. The paradox, of course, was that this implicit reckoning with the black's ignominy, this process of self-irony and self-denigration, was the necessary step on a path to a new self-image and spiritual rebirth. From the point of view of the translator, it is therefore important to translate "nègre" as "nigger" and its derivatives as derivatives or compounds of "nègre" and "nigger" (négritude, litter nigger, and nigger scum)." Translator's footnote in Aimé Césaire, Notebook of a Return to the Native Land, trans. and ed. by Clayton Eshleman and Annette Smith (Middletown, CT: Wesleyan University Press, 2001), 60. Interestingly, when in secondary school at the Mfantsipim School, Bediako's classmates referred to him as "Joe Noir"- the quintessential black man ("Call to Glory," 3).
} 
Négritude came to mean the cultural, philosophical, and political movement of suffering peoples recovering their past histories and current identities. Césaire spoke of négritude as humanization ${ }^{9}$ and believed that many peoples were capable of a négritude of their own. So for Césaire, born on a plantation, négritude meant a recovery of his African heritage. For Senghor, négritude was similar, but not identical. For him, as an African, négritude means part of what it meant to be authentically African, over and against European and colonial influences and developments. It was reflective of the African independence movement. Bediako, I will suggest, adapts Senghor's understanding of négritude to assert the independence of African Christianity. Thus, any attempt to analyze Bediako's theology and approach to scriptural interpretation without appreciating the deep influence of négritude and surrealism upon his thought would be incomplete.

Many Africans of Bediako's generation asked the defining question of identity. Aimé Césaire captured the quandary: "Who and what are we? A most worthy question!" ${ }^{10}$ While Africans do not have the disorienting displacement of slavery and the Middle Passage, the impact of Western colonization and Christianization on Africans "produce[d] an identity crisis...in a variety of forms... [including] on the place and role of Christianity in African life" (CiA, 76). In Bediako's analysis, the loss of the memory of their religious past crippled Africans' search for identity. He writes: "For theological memory is integral to identity; without memory we have no past, and having no past, our identity itself is lost" (TI, 237). The concern of identity indicates the centrality of indigeneity, self-understanding, history, and personhood for Bediako.

\footnotetext{
${ }^{9}$ Interview with Césaire in Aimé Césaire, une voix pour l’histoire, directed by Euzhan Palcy (JMJ Productions: Martinique, 2006 [1994]).

${ }^{10}$ Césaire, Notebook of a Return to the Native Land (2001), 18.
} 
African thinkers from the continent and the diaspora pose the question of identity differently. For Césaire, the question is: Who am I as I have lost connection with my ancestors and African heritage? ${ }^{11}$ For Senghor: Who am I apart from European colonizers? For Tchicaya U Tam'si, whose poetry was the subject of Bediako's French theses: Who am I as an African living in Paris as my homeland suffers through decolonization? And for Bediako: Who am I as an African studying French existentialism as an atheist who then converted to Christianity? Upon his conversion to Christianity from avowed atheism as a twenty-five year-old African graduate student living in Bordeaux, France, Bediako employed the tools of the négritude movement to establish his own personal identity as an African Christian as well as an identity for African Christianity as a non-Western religion.

\section{I.A. French Theses}

Following his undergraduate honors degree in French at the University of Ghana, Bediako pursued graduate work in Modern Languages at the University of Bordeaux studying the work of Congolese poet Tchicaya U Tam'si. ${ }^{12}$ His master's thesis,

\footnotetext{
${ }^{11}$ Césaire, along with his student and fellow négritude author Frantz Fanon, harshly critiqued the colonial processes of "civilization" and "Christianization." Their work demonstrated how Western Christianity's insistence on binaries such saved/damned or innocent/guilty came to be tied to: colonizers/colonized and white/black. Césaire, in particular, connected the atrocities of the $19^{\text {th }}$ and $20^{\text {th }}$ centuries: slavery, colonization, and the Holocaust to roots in the dichotomies of the European Christian mindset. See Aimé Césaire, Discourse On Colonialism (New York: MR, 1950, 1972), Fanon, Black Skin, White Masks, and Fanon, The Wretched of the Earth.

${ }^{12}$ Though not well-known in the English-speaking world, Tchicaya U Tam'si, the pseudonym of Gérard Felix, was described as:

1. "not only the most prolific of Africa's modern poets, but the one whose work displays the most sustained energy and intensity." Gerald Moore, Twelve African Writers (London: Hutchinson University Library for Africa, 1980), ch. 7 "The Uprooted Tree," 147.

2. "the most prolific and gifted of the second generation of francophone poets. He is also the most difficult." Thomas R. Knipp, "Négritude and Negation: The Poetry of Tchicaya U Tam'si" Books Abroad, Vol. 48, No. 3 (Summer 1974): 511.
} 
Négritude et Surréalisme: Essai sur l'oeuvre poétique de Tchicaya U Tam 'si displays

Bediako's understanding of négritude and its application to African personal identity in light of the cultural and religious challenges of the twentieth century. ${ }^{13}$ His doctorate, L'Univers Interieur de Tchicaya U Tam'si, demonstrates his awkward first attempt to integrate Christian theology into his articulation of African identity. ${ }^{14}$ Bediako's French works demonstrate the outworking of his desire to understand "what had happened to [him]" in his conversion (Ebenezer, 4). Taken together, these unpublished works offer a significant picture of Bediako's intellectual development prior to his formal theological education.

Bediako wrote Négritude et Surréalisme in two months immediately following his conversion to Christianity. ${ }^{15}$ Bediako describes his conversion this way: "In August 1970 in Bordeaux, France, in the course of my postgraduate studies in French, I experienced a rather sudden and surprising conversion to Christ" (Ebenezer, 4). Hans Visser and Gillian Bediako also described the moment: Kwame "was collared, like Saul on his way to Damascus. Taking a shower one day, the fact that Christ is the Truth, the integrating principle of life as well as the key to true intellectual coherence, for himself

3. Tchicaya "is the most prolific poet of French expression to appear since Césaire." Gerald Moore, "Surrealism and Négritude in the Poetry of Tchicaya U Tam'si," in Introduction to African Literature (Evanston: Northwestern University Press, 1970), 100. See also, John Taylor, "Rereading Tchicaya U Tam'si," The Antioch Review, Vol. 66, No. 4, Celebrity Deaths (Fall 2008): 784-790; Gerald Moore, "The Politics of Négritude" in Protest and Conflict in African Literature, ed. by Cosmo Pieterse \& Donald Munro (London: Heinemann, 1969), 26-42; and Susan Erica Rein, "Religiosity in the Poetry of Tchicaya U Tam'si" Journal of Religion in Africa 10:3 (1979). For a brief biography see Gerald Moore, Tchicaya U Tam'si, vii.

${ }^{13}$ Kwame Bediako, Négritude et Surréalisme: Essai sur l'oeuvre poétique de Tchicaya U Tam 'si, unpublished M.A. thesis (T.E.R., Bordeaux III, October 1970, 163 pages). All translations are my own. ${ }^{14}$ Kwame Bediako, L'Univers Interieur de Tchicaya U Tam'si, unpublished doctoral thesis (T.E.R., Bordeaux III, July 1973, 213 pages). All translations are my own.

${ }^{15}$ Bediako's own personal existential anguish as a writer gave him "writer's block" prior to his conversion. According to his widow, Bediako was unable to write his master's thesis - to articulate his understanding of Tchicaya's influences and emphases - prior to his conversion (Interview with Gillian Mary Bediako, 1 June 2012, Akropong-Akuapem, Ghana). 
and for the whole world, was impressed upon him with irresistible force." ${ }^{16}$ The allusion to Saul of Tarsus cannot be overlooked here. Bediako referred to his own "personal Damascus road,"17 and one can only wonder if Bediako did not feel some kinship with Paul's mission. Bediako was fond of quoting G.C. Oosthuizen's comment that "Africa had no Paul,"18 and as Paul had articulated a gospel free from legalism, Bediako articulated a gospel free from European colonialism and Western cultural categories.

Bediako understood his conversion to Christianity as a rejection of European existentialist atheism and an embrace of African identity. Bediako, looking back, includes himself

among those affected by the Enlightenment. For as a result of my own deep exposure to European intellectual culture (through studies in French to $\mathrm{PhD}$ level), I became an atheist — a strange thing to say of an African. Forty years ago, when I was pursuing my graduate studies in France, my culture-heroes were such intellectuals as Jean-Paul Sartre, Simone de Beauvoir, Albert Camus and André Malraux, among others. However, when Jesus Christ became real to me nearly thirty-five years ago, I discovered that I was recovering my African identity and spirituality. ${ }^{19}$

Bediako described this phase of his development in his last public address: "in becoming Christian, I was becoming African again." ${ }^{20}$ His French theses record the intellectual angst and future theological trajectories inherent in his self-understanding.

\footnotetext{
${ }^{16}$ Hans Visser and Gillian M. Bediako, "Introduction," in Jesus and the Gospel in Africa, xi-xii.

${ }^{17}$ Kwame Bediako, "Andrew F. Walls as Mentor," Understanding World Christianity: The Vision and Work of Andrew F. Walls, William R. Burrows, Mark R. Gornik, and Janice A. McLean, eds. (Maryknoll, NY: Orbis, 2011), 8.

${ }^{18}$ G.C. Oosthuizen, Post-Christianity in Africa: A Theological and Anthropological Study (London: C.Hurst \& Co., 1968), 235. Quoted in TI, 239, and Kwame Bediako, "Biblical Christologies in the context of African Traditional Religion," in Sharing Jesus in the Two-Thirds World, eds. Vinay Samuel and Chris Sugden (Grand Rapids: Eerdmans, 1984), 89, 95.

${ }^{19}$ Kwame Bediako, "Worship as vital participation- some personal reflections on ministry in the African church" JACT 8.2 (2005): 4. Earlier version from Calvin College Symposium on Christian Worship, 28-30 January 2005.

${ }^{20}$ Bediako, "Andrew F. Walls as Mentor," 8.
} 


\section{I.A.i.}

\section{Négritude et Surréalisme: Essai sur l'oeuvre poétique de Tchicaya U Tam'si}

After beginning his master's with a dedication, "To Him who saved me," 21 an indication of Bediako's commitment to his journey of self-understanding and of the roots of his identity as an African Christian can be found in his interpretation of Tchicaya's poetry. Bediako saw in the existential angst expressed in Tchicaya's poetry a parallel to the "first feeling of Christian conversion... a broken heart...expressed in tears" (NS, 160). For Bediako, this common anguish results in a shared humility for both the Christian and the poet. Specifically, the questions of identity posed by Tchicaya U Tam'si served as a proxy for Bediako's investigation of his own identity and reflections on the identity of Jesus Christ.

Bediako's stated goal was to identify the "spiritual itinerary" of Tchiaya's “poetic consciousness" (NS, 163). Bediako was attracted to Tchicaya's constant wrestling with his identity as an African living in Europe. In Négritude et Surréalisme, Bediako is interested in the sources of Tchicaya's thinking and writing — and no source was more interesting to him than Césaire. Although "U Tam'si occasionally echoes Césaire," Bediako is more interested in "the more inward, spiral, exploratory movement of U Tam'si" - an interior universe that Césaire's writings did not reveal. ${ }^{22}$ In Bediako's interpretation, the mark of Tchicaya's poetic consciousness is his untiring assent to purity (NS, 163). He ends his master's thesis quoting from Tchicaya's poem Epitome:

\footnotetext{
${ }^{21}$ The opening page of Négritude et Surréalisme reads: In tribute

To Him who saved me That this work of one school year May be elevated to his glory

${ }^{22}$ Moore, "Surrealism and Négritude," 105, 106. Moore identifies many sources of Tchicaya's poetry: "the inspiration of Césaire, and beyond him the technique and example of the surrealists; the sculpture, music, dancing and poetry of the Congo; and not least, his own unique genius." Moore, "Surrealism and Négritude," 109.
} 
Tomorrow I shall be pure

With birds' wings in my blue voice

To sing warry blues

To a pack of hounds

Myself their priest! ${ }^{23}$

In the midst of the struggles (the "blues") that Tchicaya felt as he sought to mediate (as a "priest") the mixed messages of colonization to his fellow Africans while facing his critics ("a pack of hounds"- real and imagined), he yearned for purity. Bediako admires this quest for purity and yearns for it in his own identity—as an African and as a Christian.

I.A.ii.

\section{L'Univers Interieur de Tchicaya U Tam'si}

Bediako struggled with the motivation to continue working on his doctorate after completing his master's thesis in October 1970, two months after his conversion. His participation in an evangelical campus ministry and local Evangelical Free Church congregation in Bordeaux, led by American missionary Bill Adams, consumed much of his time and intellectual attention. During these months, he read the Bible through from cover to cover multiple times. ${ }^{24}$ "His first impulse was to abandon his studies," reads the narrative in his funeral brochure, "and to equip himself at a Bible School in order to serve Jesus Christ. Christians in Bordeaux had a hard time persuading him to complete

\footnotetext{
${ }^{23}$ Gerald Moore, "Introduction," in Tchicaya U Tam 'si: Selected Poems, trans. by Gerald Moore (London: Heinemann, 1970), 54. Quoted in NS, 163. Senghor claimed Tchicaya's poetry in his introduction to Epitomé when he wrote: "Tchicaya is a witness whose sole end here is to manifest négritude. We have seen that he has all the negro virtues. But above all he assumes the mingled hope and despair of the negro, the epical suffering, the passion, in the etymological sense of the word." Quoted in Gerald Moore, "Surrealism and Négritude in the Poetry of Tchicaya U Tam'si," in Introduction to African Literature (Evanston: Northwestern University Press, 1970), 100.

${ }^{24}$ Visser and G.M. Bediako, Jesus and Gospel in Africa, xii.
} 
the course he had been sent to undertake. Eventually he listened." 25 Bediako continued his work on Tchicaya's poetry for his doctoral thesis, L'Univers Interieur de Tchicaya $U$ Tam 'si, completing it in July 1973.

One of the most obvious differences between his master's thesis and doctorate can be found in the sources Bediako cited in the footnotes and bibliography. The master's thesis is steeped in the authors of négritude and French existentialism: Césaire, Fanon, Senghor, Diop, and Sartre. Lacking Biblical quotations and reference to Christian authors, its treatment of spiritual themes is often quite general: it considers the "poetic personality" of Tchicaya and the "spiritual itinerary of one of the most lucid francophone poetic consciousness" (NS, 158). In contrast, the doctorate contains an abundance of Biblical material—seventy-eight Biblical references to seventy-three different verses - though there is little analytic depth in the use of these citations.

In the doctorate, Bediako combines close readings of Tchicaya's poetry with interpretive analysis based on single, isolated, Bible verses. The former influences (surrealism and négritude) are still present, but are no longer prominent. While there is a significant section on using Arthur Rimbaud and another on Maurice Blanchot, other authors such as Diop, Sartre, Senghor, Césaire (UI, 115, 129, 130), Levi-Strauss, and Fanon (UI, 130-131), are only mentioned in a footnote or two. New sources for Bediako's analysis include popular evangelical sources-Francis Schaeffer, J.I. Packer, and His Magazine published by InterVarsity Christian Fellowship, USA. In the bibliography, Bediako lists a number of evangelical authors who shape his analysis although they are not explicitly quoted: Billy Graham, J. Gresham Machen, D.L. Moody, A.W. Tozer, and B.B. Warfield. Bediako defends his use of evangelical reviews

\footnotetext{
25 "Call to Glory," 19.
} 
and magazines in a footnote within the bibliography where he claims that these

magazines intervene in a crucial way for his analysis and are "decisive for our

“evangelical vision'” (UI, 219, fn 1).

Theologically, the significance of Bediako's French doctoral thesis is that it

demonstrates his first attempt to address the twin heritage of African Christianity as

“African" and "Christian." In many ways, as compared to his later (explicitly

theological) work, L'Univers Interieur is an overreaction by Bediako-using evangelical

Christian thought - against Tchicaya's Africanness (including his négritude) as a proxy

for all Africans. Bediako's newfound joy in discovering the Christian faith and re-

discovering his "Africanness," combined with his fascination with the Bible is palpable.

\section{I.B.}

Towards an African Christian Identity

As Tchicaya was a second-generation writer within the négritude movement, so

also Bediako was a second-generation African theologian. For the négritude authors, whereas the first generation faced toward the white world, the second generation faced toward Africa-with African agonies and African hopes. ${ }^{26}$ In his theological writings, Bediako employed a similar turn in orientation within African Christian thought. Building on the insights of Kenyan John S. Mbiti whose work was oriented toward

\footnotetext{
${ }^{26}$ Gerald Moore describes the generations of négritude: “I think up to about the late 1940's or early 1950 's, the literature of Négritude is in a posture of facing towards the white world. The expression it wears on its face may vary; it may be one of reconciliation; it may be one of bringing gifts to enrich the common store; it may be an expression of hope; it may be one of grief; but the face is towards the white world, towards Europe." (38) ... [in the second generation] "Africa's face is no longer just towards the white world, but towards itself; when the hatred may be a hatred not of Europe but for other Africans, for what they do or don't do, or for what they do to each other. It may be a rejection of certain things which have taken root in African society and not things which can be shrugged off as being imported by a colonial power. The hope may be a specifically African hope, the agony a specifically African agony, and I think we find this in Tchicaya U Tam'si, a poet of the Congo." Gerald Moore, "The Politics of Négritude" in Protest and Conflict in African Literature, 38, 39.
} 
Europe, Bediako then turned his face not just to Europe, but also to himself and to

Africa, criticizing Nigerian Byang Kato for a lack of African-ness and complicity with Western thought patterns. ${ }^{27}$ Bediako, as a second generation African Christian

theologian, prepared the way in the twenty-first century for third generation theologians

who are interested almost exclusively in African concerns with little regard for Western ideas and concepts.

Upon completing his doctorate, Bediako chose not to return to the University of

Ghana, Legon to teach French, as had been expected of him. Instead, he stayed in

Europe, moving to London with his new bride. ${ }^{28}$ Looking back a few years later,

Bediako described his decision to pursue a bachelor's degree in theology at London

Bible College (now London School of Theology):

Though I was born into the Church (Presbyterian), my academic pursuits contributed to hold my intellectual and moral development in a humanist direction; in University I certainly knew an agnostic phase. It was the height of this period, in August 1970, during my doctoral studies in France, that a combination of factors brought me to a definite religious experience of Christian conversion. A deep awareness that came upon me of my need for divine grace in Christ Jesus in every area of my life, together with the conviction of the cogency and coherence of Christian truth, brought me to a major moral and intellectual crisis, and altered, in a radical manner, my total world-view. In June 1973, I felt bound to reject the invitation to join the teaching staff of the Dept. of Modern Languages in Legon. My theological studies in London Bible College (1973-1976) deepened further my conviction that theological questions must stand at

\footnotetext{
${ }^{27}$ Kato was a Nigerian who received his PhD from Dallas Theological Seminary in the USA in 1974. See Byang H. Kato, Theological Pitfalls in Africa (Kisumu, Kenya. Evangel Publishing House, 1975). See also Bediako, "A Variety of African Responses (4): Byang Kato, or Theology as Bibliology I. The emergence of a dissenting voice," TI, 386-426.

${ }^{28}$ Shortly after his conversion and completing his master's thesis, Kwame met Gillian Mary Compton in the Evangelical Free church in Bordeaux and invited her to join him in running a Good News Club for Arab children in his neighborhood ("Call to Glory," 3). They married in September 1973 in Blackburn (where Mary's parents lived in northwest England) (Ebenezer, 4). Gillian Mary joined him at LBC the following year for a theological degree.
} 
the centre of my intellectual concerns and shape my vocational commitments. $^{29}$

During these years, Bediako demonstrated a preference for historical theology-

particularly the development of doctrine-over systematic theology. His most formative

influences were two professors: Tony Lane (Patristics) and Leslie Allen (Old

Testament). ${ }^{30}$ Bediako described the impact of his theological studies as bringing him

to the settled conviction that religious faith, focused on Christ as 'the key to all [God's] wisdom and knowledge' (Colossians 2:3), had a place in the pursuit of the intellectual life. It confirmed to me that in making the transition from Modern Languages (French) to Theology, I was not mistaken, but rather, was finding a new academic vocation (Ebenezer, 4$5)$.

Bediako applied his considerable intellectual abilities to the study of Christian theology. Though his understanding of the Christian faith was shaped by a strain within American evangelicalism that was skeptical of a faith that was too intellectualized, Bediako combined a rigorous intellectual focus with the passion of a Billy Graham or A.W. Tozer. Bediako's theological vocation garnered academic praise, highlighted by his election in January 1996 as a fellow of the Ghana Academy of Arts and Sciences. ${ }^{31}$

The summer after Bediako's first year at London Bible College in July 1974, he participated as a student delegate in the Lausanne Congress for World Evangelization in

\footnotetext{
${ }^{29}$ Kwame Bediako, "Memorandum to Christian Service College Council on the work of the College," 29 May 1978, unpublished, 21.

${ }^{30}$ Interview with Gillian Mary Bediako, 1 June 2012. Personal email correspondence from Tony Lane, 6 November 2012. Bediako served as the best man in Lane's wedding.

31 "In recommending Rev. Professor Bediako for election to Fellowship of the [Ghana Academy of Arts and Sciences, elected in January 1996], Rev. Professor C.G Baëta, a senior colleague in theology testified as follows: He has applied his considerable expertise as a thinker and a scholar in French literature to his latter found vocation as Pastor and Theologian in his very thorough analysis of the central problem of the African Christian, namely his or her cultural identification with biblical theology. His in depth studies showed that there was no basis for cultural or philosophical incompatibility between the traditional values of the African and his Christian beliefs and precepts" ("Call to Glory," 9).
} 
Lausanne, Switzerland. ${ }^{32}$ The conference was significant for Bediako for three reasons. First, long-lasting friendships began "with other 'radical' Christians of evangelical persuasion from the "Two-Thirds World" (Ebenezer, 5). The connections and common concerns among David Gitari (Kenya), René Padilla (Ecuador/Argentina), Samuel Escobar (Peru), Morris Stuart and Patrick Sookhdeo (both from Guyana and working in the UK), and Vinay Samuel (India) that began at Lausanne led to the formation in the early 1980s of the International Fellowship of Evangelical Mission Theologians (INFEMIT) (Ebenezer, 5). Then in 1984, the African Theological Fellowship (ATF) was formed as the African network partner within the INFEMIT with Bediako as its director. Second, at the Congress, Bediako encountered delegates from the Presbyterian Church of Ghana (PCG) who updated him on the happenings in the PCG and "undertook to 'introduce [him] to the leaders of the church"' in Ghana (Ebenezer, 5). This meeting would later lead to Bediako's ordination as a pastor in the PCG in 1978. Third, upon returning to London, the Bediakos "opened a file in which [they] began to make occasional entries on "The idea of a Centre for Mission research in Ghana"' (Ebenezer, 5). The ideas recorded in this file resulted in the founding in 1987 of the AkrofiChristaller Memorial Centre, that was later renamed the Akrofi-Christaller Institute (ACI) for Theology, Mission, and Culture.

Upon completing their theology degrees at LBC in 1976, the Bediakos moved to Kumasi, Ghana where Kwame taught at the Christian Service College for two years. They joined Ramseyer Presbyterian Church of the PCG and Kwame began the

\footnotetext{
${ }^{32}$ 2,700 Christian religious leaders from over 150 countries participated in this first Lausanne Conference. It was intended as a follow-up to the 1910 Edinburgh conference. American evangelist Billy Graham headed a committee that called the conference. Prominent British pastor John Stott headed the drafting committee that produced the Lausanne Covenant that promoted active world-wide Christian evangelism. See http://www.lausanne.org.
} 
ordination process there. At his ordination as a new minster in June 1978, the

Moderator, the Very Rev. G.K. Sintim-Misa gave Bediako the charge to "go, study, and return to serve the church" (Ebenezer, 7). In October 1978, the Bediakos both started their doctoral studies at the University of Aberdeen under the supervision of Prof. Andrew Walls. ${ }^{33}$

Bediako responded to the disconnect he saw between much Christian theology and Africans by deciding to earn a PhD in theology. Africans needed theology written by fellow Africans, not simply by Westerners. In his "Brief Statement on a Projected PhD thesis," Bediako quotes K.A. Busia, a Ghanaian sociologist, to demonstrate that the Christian church in Ghana was popular as a social institution but that the Christian faith had little impact in the lives of Ghanaians. ${ }^{34}$ Bediako wrote: "The charge of 'irrelevance' of the Christian Church in Africa is a real problem, and one which is yet to be adequately encountered." 35 Bediako based his claim on the observation that "the Christianity of the Akan area proves to be the denominational Christianity of the West" (Ebenezer, 2). In response, he proposed, “an African reading” (Ebenezer, 4) of the Scriptures, since in his view, "The crucial question is how African theology understands and interprets Jesus Christ in the African situation." ${ }^{36}$ Bediako's lifework then was to probe the engagement of the gospel and culture in Africa for the sake of Africans and

\footnotetext{
${ }^{33}$ Gillian Mary Bediako's dissertation was later published, see Gillian Mary Bediako, Primal Religion and the Bible: William Robertson Smith and His Heritage (London: Bloomsbury Academic, 1997).

${ }^{34}$ Kwame Bediako, "Brief Statement on a projected PhD thesis, $22^{\text {nd }}$ March 1978," 5 pages plus 27 footnotes, 7 pages total, unpublished, 2. Perhaps most interesting in this document is the lack of any mention of any second century apologists. The presence of the patristics in Bediako's dissertation was only to come later at the suggestion of Andrew Walls. Bediako writes, "It was from Prof. Walls that I learnt to appreciate if I looked closely enough into the concerns of modern African theology, it was possible to wake one day and find myself in the second century of the Christian era!" (TI, xii). See K.A. Busia, The Sociology and Culture of Africa: Its Nature and Scope (University Press of Leiden, 1960) and K.A. Busia, The Challenge of Africa (New York: Praeger, 1962).

${ }^{35}$ Bediako, "Brief Statement on a projected PhD thesis," 2.

${ }^{36}$ Bediako, "Brief Statement on a projected $\mathrm{PhD}$ thesis," 7.
} 
the world. He sought to articulate an understanding of the Christian faith that was relevant to Africans, by making an impact on their lives.

\section{I.C.}

\section{"Relevance without Syncretism"}

What then is the relationship between the gospel of Jesus Christ and human cultures? Bediako identifies the stakes of the discussion: "In short, the challenge is that of relevance without syncretism" (CiA, 85). Bediako seeks an integrated understanding of the Christian faith in African cultures, and he does so by asserting the presence of the gospel in Africa prior to the arrival of European missionaries. He states this goal succinctly, borrowing from Kenyan theologian John S. Mbiti, in the title of a 2006 lecture: "Missionaries did not bring Christ to Africa; Christ brought them.. ${ }^{37}$ Bediako's Christological view of history therefore extends prior to the New Testament itself. He writes, "Indeed, the gospel was before the New Testament. In that sense, the gospel existed before our traditions, before our cultures. ${ }^{38}$ For him, the gospel existed within African culture no less than it did in the people of Israel. By conceiving "gospel" as the gracious actions of God towards humanity in a historical, providential way, Bediako rethinks the history of African peoples.

Since Bediako frequently uses the terms "gospel" and "culture," it is important to consider how he understands each term as well as the interaction between them. In the

\footnotetext{
${ }^{37}$ Kwame Bediako, “"Missionaries did not bring Christ to Africa—Christ brought them': Why Africa needs Jesus Christ" AICMAR Bulletin 6 (2007).

${ }^{38}$ Kwame Bediako, "Scripture as the hermeneutics of culture and tradition." JACT 4:1 (2001): 2.

Originally given as lectures 9-13 August 1999, Akrofi-Christaller Memorial Centre, Akropong-Akuapem, Ghana.
} 
1988 New Dictionary of Theology, Bediako provided the entry for "Culture. ${ }^{, 39} \mathrm{He}$ began with a disclaimer: "Culture is a term that is not easily definable." ${ }^{, 40}$ Then he continued, pushing his main point:

However, if we take culture to mean the ways of thinking (culture begins internally) and behavior shared by a substantial social grouping of persons, which give them identity in relation to other social groupings, then it is evident that all persons participate in one culture or another. There is no individual who has no culture. ${ }^{41}$

Significant here is the relationship that Bediako sees between culture and identity: "culture...give[s]...identity.” Bediako's own wrestlings with identity as an African and a Christian (and the concerns of fellow Africans) led him to better understand and articulate the discontinuities of African culture - that is, culture must emerge from within a group of persons and not be imposed externally. In this way, culture and identity are inseparable. Bediako routinely insists that no person or group of people could exist outside of culture. Thus, not only people, but also their thoughts, convictions, and theologies are rooted within culture. Culture, then, is "all-embracing" and "inescapable." ${ }^{42}$ Further, culture is not fixed but instead "like human life itself, culture is dynamic, adaptable and open to transformation both within itself, and in response to new and external factors. ${ }^{43}$ While culture is the collection of human thinking and behavior that is shared by a group of people that gives them identity, in practice, individual cultures are fluid and ever changing in response to internal and external developments. African cultures, then, are the combination of their histories and present circumstances.

\footnotetext{
${ }^{39}$ Kwame Bediako, "Culture," in New Dictionary of Theology, eds. Sinclair Ferguson and David Wright, (Downers Grove, IL: InterVarsity Press, 1988), 183-185.

${ }^{40}$ Bediako, "Culture," 183.

${ }^{41}$ Bediako, "Culture," 183; and Kwame Bediako, "Gospel and culture: some insights for our time from the experience of the earliest Christians." JACT 2:2 (1988): 8.

42 Bediako, "Gospel and culture," 8.

${ }^{43}$ Bediako, "Gospel and culture," 8.
} 
As a key point of contrast, the gospel is fixed on the person of Jesus Christ. Bediako defines "The Gospel, in the true sense of the word, [as] who Christ is, and what he means, in his person, his life on earth, his work, his death, his resurrection and its aftermath, and how all that concerning him relates to all human beings, in all our cultural traditions, histories, and environments." ${ }^{44}$ Even though the "gospel was before the New Testament," 45 Bediako's gospel has significant historical rooting in the person of Jesus Christ. In part this conviction amounts to the rationale for why the "Gospel and culture cannot be separated, ${ }^{, 46}$ for Christ cannot be separated from his earthly body. Bediako bases his conviction on John 1:14. Since, “"The Word became flesh' [is] not some abstract, general humanity,"47 the gospel (God's Son coming to earth as a human being) is concretized in a specific way. This connection of gospel with culture is then rooted and given in the Incarnation. Bediako writes, "If the Gospel, therefore, is the person of Jesus Christ of Nazareth, his ministry, his death, his resurrection and its aftermath, as given us in the Scriptures, then it shows the Gospel can no longer be viewed as independent of culture. ${ }^{\text {48 }}$ In the same way that human beings cannot be separated from culture, neither, for Bediako, can the gospel be separated from its human embodiment in Jesus Christ or human cultures. As will be discussed in later chapters, Bediako's understanding here differs from Barth's. While Barth insist on the uniqueness of the gospel as always identifiable amidst culture, Bediako begins with the interconnectedness between culture and religion in African cosmology to assert that gospel and culture cannot be separated.

\footnotetext{
${ }^{44}$ Bediako, "Gospel and culture," 8.

${ }^{45}$ Bediako, "Scripture as the hermeneutics of culture and tradition," 2.

${ }^{46}$ Bediako, "Gospel and culture," 9.

${ }^{47}$ Bediako, "Gospel and culture," 9.

${ }^{48}$ Bediako, "Gospel and culture," 8-9.
} 
While the mingling of gospel and culture does not worry Bediako, ${ }^{49}$ he is concerned that Christian theology can be captured by culture. In fact, this is precisely the claim Bediako makes about most Western theology and some African theologies, such as Africania ${ }^{50}$ Bediako is wary of any theology claiming to be above, outside of, or apart from culture. But there is also a mutually enlightening relationship between gospel and culture. In the interaction between the two, the gospel teaches about culture and culture teaches about the gospel. Such interaction is an inevitable part of human existence and as such should be welcomed and probed for meaning, without trying to escape or avoid it. Even more than understanding the inevitable, however, Bediako sees potential learning through the interaction. The key question is how to distinguish "bad" interaction between gospel and culture (such as in colonialism) from "good" interaction. For Bediako, the first step is an awareness of the cultural blinders that everyone brings to the process of biblical interpretation and theological reflection. The second step is for a theology to be examined for cases where culture obscures the gospel.

Culture, then, is not a neutral quantity. Culture is very powerful in shaping the identities of individuals and in pointing them towards or away from Jesus Christ. Bediako believes that "There is within every tradition of culture, history, identity and continuity, elements which lead to Jesus and affirm him as Lord; but equally, there are within every tradition, elements that lead away from Jesus and deny him.. ${ }^{, 51}$ Historically, he has seen a tremendous amount of Western attention devoted to combating syncretism in churches and theologies of the developing world, but "an insufficient alertness to

\footnotetext{
${ }^{49}$ Kwame Bediako, "Gospel and culture: Guest Editorial," JACT 2:2 (1999): 1.

${ }^{50}$ See Bediako, "African Identity: The Afrikania Challenge," CiA, 17-38.

${ }^{51}$ Bediako, "Gospel and culture," 12.
} 
similar phenomena threatening the churches of the West." ${ }^{, 52}$ Bediako's view of Western theology is that it is syncretistic with Western culture and distorts the gospel. Therefore, translating this distorted, Western gospel is not enough for churches in the global South. They must go further. They must seek alternative sources to shape an African Christian identity. And Bediako believes these sources already reside within the heritage of African religions.

As African theologians started to emerge, in their quest to understand their identity as African Christians, they found themselves seeking out "their own religious heritage; which is, indeed, a proper task of theology...[T]his new theological approach had no counterpart in the more recent Western theological thought forged within the context of Christendom. ${ }^{, 53}$ Within the context of Christendom, religious identity was inherited from one's surrounding culture without intentional effort. Yet in the postcolonial African context, "Identity itself thus became a theological category, so that the development of theological concern and the formulation of theological questions were linked as the inevitable by-product of a process of Christian self-definition" (CiA, 256). The search for an authentic African Christian identity was a truly theological endeavor as Christians sought traces of religious memory in the past to better understand themselves in the present. This is a shift from unselfconscious inhabitation of context to a purposeful pursuit of identity through the appropriation of African spirituality and religiosity within Christianity.

Bediako repeatedly stressed that African Christians had a past and that they need to know it, "For theological consciousness presupposes religious tradition, and tradition

\footnotetext{
${ }^{52}$ Kwame Bediako, "Willowbank Consultation," 26.

${ }^{53}$ Bediako, "Understanding African Theology," Jesus and the Gospel in Africa, 53.
} 
requires memory, and memory is integral to identity: without memory we have no past, and if we have no past, we lose our identity." ${ }^{, 54}$ For Bediako, people without a history have no identity. And this poses a significant problem: Bediako understood part of the colonial project as interjecting a substitute past into the African past. Colonialism “threatened to deny African Christians their own past and sought instead to give them a past which could not in any real sense become fully theirs" (TI, 237). ${ }^{55}$ Yet each culture can and should experience the gospel of Jesus Christ directly based on their own experiences. Just as Aimé Césaire and other authors of négritude reconnected the black peoples brought to Martinique and the Antilles to their African past, so Bediako sought to connect African Christians to their dual heritage as Africans and as Christians.

Even after Western influences stopped overtly trying to impose Western Christianity on Africa, truly African theology had not been welcomed within Western theological circles. For Bediako,

The overall goal of African theology was to show that there were genuinely and specifically African contributions-derived from the twin heritage of African Christianity, namely, the African primal tradition and the African experience of the Christian Gospel — to be made to the theology of the universal Church. ${ }^{56}$

Through his act of theological négritude, Bediako searched for and found a history for African Christians, recovering a cultural and religious memory as the basis for an African Christian identity. He articulated this history as "the twin heritage of African Christianity" to which we will now turn, starting with the African Christian experience of the gospel and then the African primal tradition.

\footnotetext{
54 Bediako, "Understanding African Theology," 51.

${ }^{55}$ See also Bediako, "Understanding African Theology," 53.

${ }^{56}$ Bediako, "Understanding African Theology," 56.
} 


\section{I.D. \\ History: Twin Heritage of African Christianity}

Bediako primarily performed the task of connecting twentieth-century African

Christianity with its Christian past in Theology and Identity: the impact of culture on

Christian thought in the second century and modern Africa ${ }^{57}$ He clearly articulated his

goal in the Introduction:

Whilst the book seeks to make a contribution to the understanding of modern African Christianity, it seeks to do so by situating twentiethcentury African theology within the organic tradition of Christian theology as a whole. Accordingly, the book attempts to remove African theology from the historical limbo in which it has often been held, caught between African 'non-Christian' beliefs and values on the one hand, and Western 'Christian' ideas on the other. By focusing on the problems of forging Christian identity in the context of the religious pluralisms of the second century of the Christian era and modern Africa, I wish to suggest that it is possible to ask fresh questions of the Christian tradition of the past, questions which can in turn illuminate the task of constructing local theologies and the doing of theology in our religiously pluralistic modern world (TI, xii).

Bediako understood African Christianity as "within the organic tradition of Christian

theology," so it was not a foreign element that needs to be grafted in later on, but instead a natural part of Christian theology that goes back to its beginnings. As such, Bediako connected twentieth century African Christianity to its precolonial Christian past, eliminating African Christianity from its "historical limbo."

For Bediako, a line can be drawn (akin to the red thread of history from Barth's

\footnotetext{
${ }^{57}$ In Theology and Identity, Bediako treats four authors from the second century CE: Tatian, Tertullian, Justin Martyr, and Clement of Alexandria. These four authors were all first generation converts to Christianity and reflected on how to interpret their pagan past in Greco-Roman religions, in light of their faith in Jesus Christ (TI, 32). These second century apologists saw "no more pressing problem to be faced by Gentile Christians in the Graeco-Roman world than the question of their heritage and historical roots." (TI, 35). The similar concerns of these apologists and the four modern African theologians (Bolaji Idowu, John S. Mbiti, Mulago gwa Cikala Musharhamina, and Byang Kato) forms the basis for the book. In his analysis, Bediako's preference for the thought of Justin and Clement shines through.
} 
Romans $)^{58}$ from the earliest Christian theologians directly to modern African theologians-without having to go through European mediators. The result connects the African present to its Christian past and also enables African Christians to articulate their own understanding of the gospel within their own context. Put summarily: African Christians can articulate the gospel within a religiously pluralistic modern world in a way that, in Bediako's analysis, Western theologies based in a worldview shaped by Christendom and the Enlightenment may be incapable of doing.

In Justin Martyr, Bediako found an early example of continuity between a preChristian past and a Christian present. Justin claimed that there were "Christians" before Christ and "that he and the Christians of his own day had a common cause with those of the past" (TI, 150). For Justin, as later for Bediako, "the truth of the Christian Gospel is the truth of the person rather than of the religious tradition to which one belongs" (TI, 156). The person of Jesus Christ, "the Word Himself" (TI, 152), was the source of Christian knowledge and the conduit for participation in God. In Justin, he saw an apologist who while "interpreting the past...is also explicating the present" (TI, 149). Bediako did not study the early fathers merely for their roles in the development of Christian doctrine, but rather saw them as making a valuable contribution to contemporary discussions of Christian identity.

Bediako argued that Clement of Alexandria built on the continuity articulated by Justin. He saw here a "universalizing of 'salvation-history' ...[that] involves the Christianising not only of Hellenistic tradition, but the Jewish also; 'holy pagans' and Jewish saints become 'Christians before Christ,' on the same terms; and the Old Testament, by virtue of Christ foreshadowed therein, becomes a Christian book" (TI,

\footnotetext{
${ }^{58}$ Karl Barth, Epistle to the Romans, 96.
} 
160). Bediako latches on to the universalizing approach of Clement. For Clement "the Christian account of reality... supersedes the entire history of intellectual and philosophical speculation in Hellenistic tradition...by absorbing it" (TI, 80). The superiority of the Christian understanding enabled it to absorb the Hellenistic tradition. And yet, whereas the process of absorption of the Jewish and Hellenistic religious traditions by Christianity is acceptable to Bediako, the absorption of primal African religious traditions to Christianity is somewhat problematic. Bediako considers African religions to be a free-standing substructure of Christianity; he considers Hellenism to be the beginning of the Western tradition that departs from primal religious understandings and, in the long run, distorts the Christian faith.

Though Bediako did not, one could use his approach to postulate a Hellenistic substructure of Western Christianity by re-reading the Hellenistic tradition as a distinctive preparation for Christianity (akin to the Apostle Paul's Mars Hill speech in Acts 17) ${ }^{59}$ In this way, while Bediako's (and Clement's) Christianity would still be universalizing, it would not be totalizing. The absorption of Hellenistic religiosity would be complemented by the preservation of African religiosity. Bediako hints in this direction in his concluding comments on Clement: "Advancing beyond Justin, Clement even postulated a tradition in Hellenistic culture which bore witness to an apprehension of the divine truth in the Hellenistic past" (TI, 207). Bediako sought a similar presence of divine truth within the African past. The advantage of Clement's views, according to Bediako, was that they connected Christians as part of an ancient nation through the Old Testament "with laws and traditions which entitled them to a place in the common

\footnotetext{
${ }^{59}$ Bediako draws this connection explicitly: as "St. Paul declared on Mars Hill, in Acts 17:27, in another time and place where a Christian account of the Transcendent was being forged in an encounter with a primal worldview, the Hellenistic worldview being essentially primal" (CiA, 101).
} 
history of mankind, a right that was being denied them by Graeco-Roman

traditionalists" (TI, 203-204). All told, Clement's task was "integrating Christian faith with culture" (TI, 207) and Bediako understands himself to be doing the same as a modern-day apologist for Christianity in Africa with implications for Christianity itself and the wider world. ${ }^{60}$

While the thrust of Bediako's work builds on the view of history and the universalizing role of the Christian faith espoused by Justin Martyr and Clement of Alexandria, the deeper connection still is with person of Jesus Christ revealed in the scriptures of the Old and New Testaments. Bediako's underlying theological conviction is that Africans are fully human, created by God, and that Christ's governance of history encompasses Africa as well as the West. He writes, "The fact of the matter is, if Jesus Christ is not in the cultural heritage of African peoples, then Africans as human beings would not have been created in and through Jesus Christ, the Word of God, Agent of creation, and the Second Adam and New Man. ${ }^{.61}$ Put a bit differently: because God created Africans as human beings in the image of God, Jesus Christ is the cultural heritage of Africans just as much as Europeans.

Bediako's act of theological négritude identifies a past for African Christians that articulates an African Christian identity based on his belief that there is a direct connection between Africans and God in Jesus Christ. This act is intentional on Bediako's part and is informed by his understanding of: (1) the infinite translatability of the gospel, (2) the continuity of Christianity with African traditional religion, (3) the

\footnotetext{
${ }^{60}$ In his final public appearance, a tribute to Andrew Walls, Bediako compared himself to Clement of Alexandria and Walls to Clement's teacher, Pantaenus (Bediako, "Walls as Mentor," 8).

${ }^{61}$ Bediako, "Missionaries did not bring Christ to Africa," 21.
} 
indigeneity of Christianity in Africa, and (4) the primal imagination as substructure of African Christianity. These four concepts are described in the following section under the headings: Revelation, Religion, and Culture.

II. Revelation, Religion, and Culture

Historically, an interest in African Christian identity arose in response to how the Europeans conducted their missionary efforts. Bediako writes:

the ethnocentrism of a large part of the missionary enterprise not only prevented sufficient understanding of African religious tradition, but also led to a theological misapprehension of the nature of the Christian Gospel itself. African theology in the post-missionary era, therefore, is as much a response to missionary underestimation of the value of African pre-

Christian religious tradition, as it is an African theological response to the specific and more enduring issues of how the Christian gospel relates to African culture. Thus modern African Theology emerges as a theology of African Christian identity (TI, xvii).

Not only did the unreflective and unintentional ethnocentrism of European colonial missionaries forcibly separate Africans from their own history and traditions, a broader problem resulted: the theological myopia of the missionaries conveyed "a theological misapprehension of the nature of the Christian Gospel itself" (TI, xvii). Given this historical legacy, African Christians cannot merely appropriate the "gospel" of colonial missionaries - a gospel that, because of its cultural wrappings, was never wholly good news for Africans. Bediako's project, then, was to "discover fresh insights into the eternal purposes of God towards His creation. These could well be such as Western Christianity has culturally been unable, hitherto, to see. ${ }^{, 62}$ By receiving the gospel of

\footnotetext{
${ }^{62}$ Bediako, "Willowbank Consultation," 31.
} 
Jesus Christ afresh with African ears, bypassing Western intermediaries, Bediako aimed to articulate a distinct African Christian identity.

\section{II.A. \\ Revelation: Infinite Translatability of the gospel}

An African Christian identity is possible because of "the infinite translatability of the gospel of Jesus Christ." 63 Though he borrows the phrase from Andrew Walls, ${ }^{64}$ Bediako builds his entire theology on the insight that "the translatability of the Christian religion signifies its fundamental relevance and accessibility to persons in any culture within which the Christian faith is transmitted and assimilated" (CiA, 109). As such, the Christian faith is relevant and accessible to anyone in any culture on earth. The translatability of the Christian faith defines its uniqueness and its universality. ${ }^{65}$ The phrase, "Translatability is another way of saying universality," is well loved and often repeated by Bediako $(\mathrm{CiA}, 109) .{ }^{66}$ He believes both in the translatability of the Christian scriptures as well as the translatability of the gospel itself. ${ }^{67}$ The gospel is the person,

\footnotetext{
${ }^{63}$ For an extended treatment of translatability by Bediako see "Translatability and the Cultural Incarnations of the faith," chapter 7 in $\mathrm{CiA}, 109-125$.

${ }^{64}$ As early as 1987, Bediako writes, "with what Professor Andrew Walls has taught us to call the Christian faith's 'infinite cultural translatability"” (Bediako, "Christ in Africa: Some Reflections on the Contribution of Christianity to the African Becoming" in African Futures, 453). For Walls' usage, see Walls, Missionary Movement in Christian History, 22.

${ }^{65}$ Kwame Bediako, "The relevance of a Christian approach to culture in Africa," in Christian education in the African Context (Proceedings of the first Africa regional conference of the International Association for the Promotion of Christian Higher Education--IAPCHE, 4-9 March 1991, Harare, Zimbabwe, Grand Rapids: IAPCHE), 31.

${ }^{66}$ See also: Kwame Bediako, "The relevance of a Christian approach to culture in Africa," 31; and Kwame Bediako, "Biblical Exegesis in the African Context: The Factor and Impact of Translated Scriptures" JACT 6.1 (2003): 17.

${ }^{67}$ Bediako's understanding of the translatability of the gospel shares distinct similarities with Lamin Sanneh, Translating the Message: The Missionary Impact on Culture (Maryknoll, NY: Orbis, 1989). Sanneh and Bediako overlapped in Aberdeen while Bediako was a PhD student. Sanneh was a faculty member in the department of Religious Studies; the department chair was Andrew Walls. It was Walls who asked Sanneh to teach courses in Christianity, outside of his graduate training in Islam.
} 
life, and work of Christ that is expressed in the scriptures. ${ }^{68}$ And both translations are possible because of the initial act of translation: God taking human form in the person of Jesus Christ. ${ }^{69}$ Or as Bediako puts it, the "Christian claim is that in Jesus Christ 'Divinity became translated into humanity.",70

The basis for his claim of translatability is, once again, John 1:14: "The Word became flesh and dwelt among us" (CiA, 110). ${ }^{71}$ Because of the Incarnation, "Translatability...may be said to be in-built into the nature of the Christian religion and capable of subverting any cultural possessiveness of the Faith in the process of its transmission" (CiA, 110). Translatability is an inherent characteristic of the Christian faith. It undergirds "the true character of continuing Christian witness and enhance[s] the genuine development of new indigenous traditions of Christian thought" (CiA, 110). Moreover, the process of translation must occur anew in every distinct culture.

Transporting one cultural translation of the gospel to a different culture without allowing the gospel to be translated anew can have harmful consequences. ${ }^{72}$

While Bediako's understanding of the gospel is universal in application, theological reflection is necessarily provisional. This is because "all theology, wherever it is produced, is contextual and therefore provisional rather than universal, and that theology itself is always a struggle with culturally-related questions" (CiA, 129).

\footnotetext{
${ }^{68}$ Bediako, "Gospel and culture," 8.

69 "But underlying the translatability of the Christian Scriptures lies the prior act of divine translation, the Incarnation, for the divine "Word became flesh and dwelt among us (John 1:14)." Kwame Bediako, "Challenges of Ghana's Fourth Republic: A Christian Perspective" (The William Ofori-Atta Memorial Lectures, lecture 2, 7th- 9th October 1992), 7.

${ }^{70}$ Kwame Bediako, "Islam and the Kingdom of God" (Stone Lecture \#3, Princeton Theological Seminary, Princeton, NJ, October 21, 2003).

${ }^{71}$ See also, Bediako, "The relevance of a Christian approach to culture in Africa," 31.

${ }^{72}$ For a tragic example of what can happen when Christian missionaries fail to allow the gospel to be translated into a host culture, see Tim Hartman, "Lost in Translation: Postcolonial Reflections on "The Panare killed Jesus Christ"” Cross Currents 63:3 (September 2013): 328-349.
} 
Understandings of the gospel, or simply put, theologies, are culturally bound and subject to error and misinterpretation. As such, "theology can be authentic only in context." ${ }^{, 73}$ It follows, for Bediako, that any attempt at a universal theology, that is, an a-contextual theology, creates a false gospel. In fact, the consequences of misplaced cultural confidence in such a "false gospel" are devastating for Bediako. He writes, "The price that is paid by converts to such a truncated Gospel is incalculable." ${ }^{, 74}$ Bediako has in mind here the damaging erasure of African cultural and religious memory through colonial missions. This deep concern — that the scriptural witness of the gospel is corrupted by blind adaptation of cultural assumptions — drives his work.

Bediako's fundamental critique of Western Christianity is its implicit, and uncritical, embrace of Western culture as inseparable from the gospel; he regularly criticized Western formulations of the gospel as pure and untranslated. European missionaries failed in assuming that the translation process was complete, once and for all, when the gospel was translated into Western culture. Instead of bringing "the gospel" to Africa, as many naively assumed, the missionaries brought a bastardized version of Christianity — a hybrid of the gospel of the Christian faith and Western culture - that they passed on as the pure, unadulterated, unencultured, gospel. This approach prevented Africans from developing indigenous understandings of the Christian faith; they were simply asked to receive Western Christianity as "the gospel." The missionary practice of imparting their Western understanding of Christianity perpetuated the notion that Christianity was foreign to Africa and that the gospel did not need to be translated.

\footnotetext{
${ }^{73}$ Kwame Bediako, "Biblical Christologies in the context of African Traditional Religion," 98.

${ }^{74}$ Bediako, "The Willowbank Consultation," 29.
} 
Interestingly, Bediako is charitably understanding towards the missionaries, and particularly grateful to them for bringing the Bible to Africa and translating it into so many African mother-tongues (CiA, 185, 203). Yet, he sees the encounter of Western Christianity with African culture, not as invalidating Christianity, but as unmasking Western Christianity for what it is. Bediako writes,

Not only in demographic terms, but in some other respects too, Christianity has become a non-Western religion...It is not that Western Christianity has become irrelevant, but rather that Christianity may now be seen for what it truly is, a universal religion, infinitely culturally translatable - capable of being at home everywhere without loss to its essential nature. ${ }^{75}$

Through the infinite translatability of the gospel, Bediako asserts that "Christianity ...[is] capable of being at home everywhere without loss to its essential nature.,"76

Therefore, in Africa, and given the colonial history, seemingly even in Africa, the gospel of Jesus Christ (the "essential nature" of Christianity) can take an authentic form. ${ }^{77}$

Bediako understood the revelation of the gospel in Africa to have begun in and through African traditional religion and to have continued to completion in African Christianity.

\section{II.B. \\ Religion: Continuity of African Christianity with traditional African Religion}

The first step in identifying and articulating the African religious aspect of the twin heritage of African Christianity was to undo the assumptions of many Western colonial missionaries about traditional African religions. Bediako first conducted this

\footnotetext{
${ }^{75}$ Kwame Bediako, "The impact of the Bible in Africa," epilogue in Ype Schaaf, On their way rejoicingThe history and role of the Bible in Africa, (Carlisle: Paternoster Press, 1995), 244.

${ }^{76}$ Bediako, "Impact of the Bible in Africa," 244.

77 "Accordingly, the popular notion of Christianity as 'the white man's religion' or Western religion, is effectively set aside, for African Christianity is no less Christian for being mediated through African languages, whilst Western Christianity does not enshrine universal standards. On the contrary, the very possibility of Scripture translation, as well as the elements that come into play through it, demonstrates that an African 'incarnation' of the Faith is valid too" (CiA, 121).
} 
ground-clearing in Theology and Identity. The first assumption to undo was that of a religious vacuum, that Africans were a religious tabula rasa. Following Cameroonian Mulago gwa Cikala Musharhamina, Bediako embraced the role of a Christian theologian retrieving African religious identity. He took "theological responsibility for one's cultural community" (TI, 353) by retaining and translating its resources in light of the gospel. Indeed all of Bediako's work, starting in Theology and Identity, has attempted to valorize, or at least give a positive account of, the traditions and rituals of African Traditional Religion. He has demonstrated that Africans have a religious past that makes constructive contributions to African Christian thought that had been elided by Western, colonial presuppositions.

As Bediako understands it, Africans have worshipped God, even before they knew the name of God as Jesus Christ. However, instead of treating traditional religions as "paganism" (similar to Hellenistic religion), Bediako followed Mbiti's claim that African primal religions are in fact, praeparatio evangelica (evangelical preparation for the gospel; TI, xvii, 149, and 315). ${ }^{78}$ That is to say, Bediako found a pre-Christian African religious history that he claimed had prepared Africans for Christianity. In the most basic terms, African Christian thought combines the Christian faith with African primal religious traditions. For Bediako, "primal" is not a euphemism for primitive; it is a positive term in its own right, meaning, "universal, basic elements of human understanding of the transcendent and of the world, essential and valid religious insights that may be built upon or may be suppressed but that cannot be superseded.",79

\footnotetext{
${ }^{78}$ See also: Bediako, “'Their past is also our present.' Why all Christians have need of ancestors: Making a case for Africa" AICMAR Bulletin 6 (2007): 9.

${ }^{79}$ Bediako, "Recognizing the Primal Religions" (Stone Lecture \#2, Princeton Theological Seminary, Princeton, NJ) October 21, 2003.
} 
Further, the uniqueness of African Christian thought lies in its appropriation of this primal imagination. Bediako turns to the primal to articulate an authentic African Christian identity. He does so in part by claiming that the names given to deities in African mother-tongues can and should be applied to God in Jesus Christ. One God has been active in Africa.

The appropriate name(s) used to refer to God is key topic of discussion surrounding the indigenous nature of Christianity in Africa. The basic contrast that Bediako draws is between what happened in Europe and what happened in Africa when the Christian religion was first introduced.$^{80}$ Many missionaries to Africa, in contrast to the conquerors of Europe, sought out the name for God within an Africa culture and identified that name with God in Jesus Christ. While this may certainly be viewed as a totalizing move by an occupying power, it has allowed for continuity between African primal religions and Christianity that has encouraged the primal religions to continue. In a footnote in Christianity in Africa, he observed, "It is extraordinary, for instance, how the African names for God in African indigenous languages have made an easy transition into Christian vocabulary to designate the God of the Bible - a feature which

\footnotetext{
${ }^{80}$ Bediako writes, "whereas Christian proclamation in northern and western Europe swept away the traditional governance of a practically new deity with the neutral name of "God," in Africa, the bearers of the Christian faith encountered a well-rooted belief in one great God, Creator and Moral ruler of the universe and one not too distinguishable from the God of the Old and the New Testament traditions. Prior to the Christian era in northern and western Europe, Hellenistic Christians had identified the God of the Bible with the "God" of Plato and the concept of the highest good in the Greek philosophical tradition - a "God" without a name, generally described in negative categories and usually spoken of in abstract terms. It is this identification which was urged upon the northern and western peoples and which was to dominate Christian thought in Europe for centuries to come. In Africa the identification of the God of the biblical tradition was made with One who has had for generation a traditionally venerated name in indigenous languages and it is the divine name in the vernacular which has on the whole passed into Christian devotion. The effect of this circumstance in providing a starting point for theological thought - quite different from that of the previous phases of Christian history will be incalculable" ("The Holy Spirit, the Christian Gospel and religious change: the African evidence for a Christian theology of religious pluralism," in Essays in Religious Studies for Andrew Walls, ed. James Thrower. Aberdeen: Department of Religious Studies, University of Aberdeen (1986): 47).
} 
was lacking in the earlier missionary history of Europe" (CiA, 99). As a result, "The God of the Bible turned out to be the God whose name has been hallowed in vernacular usage for generations. This did not happen in Europe" (CiA, 55) ${ }^{81}$ Put more boldly, Bediako wrote that, "in Africa the God whose name had been hallowed in indigenous languages in the pre-Christian tradition was found to be the God of the Bible, in a way neither Zeus, nor Jupiter, nor Odin could be. Onyankopon, Olorun, Ngai, Nkulunkulu are the names of the God and Father of Jesus Christ; Zeus, Jupiter, and Odin are not." ${ }^{\$ 2}$ Ironically, then, the decision of European missionaries to use African names for the divine being, God, suggests and highlights the continuity between ATR and Christianity. At the same time, an implication of this claim of continuity is that the Akan people can no longer maintain a partial or incomplete understanding of Nyame, the Twi name for God. For Bediako, Nyame has been revealed to be the God and Father of Jesus Christ. This revelation of the fullness of who God is supersedes the prior understanding of the human person in African thought. Indeed, the coming of God in Jesus Christ changes what it means to be a human being; or at least, the revelation of God in Jesus Christ reveals who all humanity—including Africans_-have been, are, and will be, whether they knew it or not. Put differently, while the traditions and the imagination of traditional African religions remain in the twenty-first century, the understanding of human beings in their relationship to the divine has been radically altered. The ancestors do not mediate the relationship between Nyame and humanity; instead, mediation occurs through the Supreme Ancestor, Jesus Christ, the Son of God. Furthermore, the direction

\footnotetext{
${ }^{81}$ On this point, see also Patrick J. Ryan, “'Arise O God!' The Problem of 'Gods' in West Africa” Journal of Religion in Africa XI:3 (1980): 161-171.

${ }^{82}$ Kwame Bediako, "The significance of modern African Christianity—A Manifesto," Studies in World Christianity (The Edinburgh Review of Theology and Religion) 1:1 (1995): 54. Also in Kwame Bediako, "Cry Jesus! Afua Kuma" in Jesus and the Gospel in Africa, 16-17.
} 
of the relationship has been reversed. Instead of the living seeking help from the ancestors to communicate with Nyame and the spirit-world, in Jesus Christ, Nyame has sent his Son to lead people into full relationship with God through the Holy Spirit.

A more critical claim ventured here is that European Christianity is relatively impoverished. Although "Europe shares with Africa an identical pre-Christian heritage in the primal religious traditions of the world" (CiA, 260) ${ }^{83}$ Bediako argues that the Christianization of Europe happened through forces that "proceeded on a basis of substitution to such an extent that the primal traditions were virtually completely wiped out. ${ }^{\prime 84}$ Scant traces of European primal religions remain in Western culture today. The wholesale substitution of the Christian religion in place of European primal religions, "together with the fact that there was no sustained interest in the use of indigenous European languages and their pre-Christian world-views for Christian purposes, ${ }^{, 85}$ has damaged the Western religious memory beyond recovery. Yet, as Bediako points out, "the old beliefs had not entirely lost their hold upon people's minds," ${ }^{, 86}$ as "Christians continued to name the days of the week after pre-Christian deities, and pre-Christian elements and notions made their way into the celebration of Christian festivals. ${ }^{\not 87}$ These semantic connections point to a primal European past that has been lost.

In a sense, then, it appears to Bediako that many European missionaries to Africa simply proceeded to "do" missions as missions had been "done" to their ancestorswiping out the local traditions and wholly substituting a Western understanding of the

\footnotetext{
${ }^{83}$ See also Bediako, "Understanding African Theology," in Jesus and the Gospel in Africa, 59; and Bediako, "The impact of the Bible in Africa," 248.

${ }^{84}$ Bediako, "Understanding African Theology," 59; and Bediako, "The impact of the Bible in Africa," 248.

${ }^{85}$ Bediako, "Understanding African Theology," 59.

${ }^{86}$ Bediako, "Understanding African Theology," 59.

${ }^{87}$ Bediako, "Understanding African Theology," 59.
} 
Christian God. Yet with some unexpected benefits: European colonization was not (primarily) military conquest but instead a process of "civilization" with an economic upside. The European colonizers, moreover, did not eliminate all traces of African primal religions. Bediako sees this situation as a tremendous opportunity for African Christian thought. He writes,

It may be that in Africa the opportunity lost in Europe for a serious and creative theological encounter between the Christian and primal traditions, can be regained. ...African theology gains rather than loses. For, having been forced to do theology in the interface of their Christian faith and the perennial spiritualities of their African primal heritage, and having to internalize that dialogue within themselves, African theologians have restored the character of theology as Christian intellectual activity on the frontier with the non-Christian world as essentially communicative, evangelistic and missionary. ${ }^{88}$

From its origins then, African Christian thought is well placed to imagine Christianity anew as an encounter between the gospel and culture. From Bediako's vantage point, "African theological writing came to focus on giving a more positive interpretation of the African religious past than the missionary assessment had done, and so demonstrated the continuity of the religious past with the Christian present" (CiA, 76). The Christian faith is continuous with the religious past of Africans.

\section{II.C. \\ Culture}

Bediako's positive assessment of ATR and African culture countered the prevailing assumptions of European colonial missions, in particular, as was described in chapter 1, the 1910 Edinburgh conference that declared Africans as without a religious heritage and their rituals as pagan. Instead of viewing ATR and African culture as

\footnotetext{
${ }^{88}$ Bediako, "Understanding African Theology," 59.
} 
problems for African Christianity, Bediako viewed them as full of possibilities. He expressed the differences between these perspectives in the following quotation:

Rather than constituting a prison that inhibits our human development, and therefore a prison from which we are to break free in order to experience salvation in a so-called 'Christian culture' brought in from outside, our African cultural heritage is in fact the very place where Christ desires to find us in order to transform us into his image. ${ }^{89}$

African culture, in short, is the site of the engagement between the gospel and Africans. This sub-section considers two frequently-discussed topics - indigeneity and the primal imagination — that contribute to Bediako's understanding of "culture."

\section{II.C.i.}

\section{Culture: Indigeneity of Christianity in Africa}

The engagement between gospel and culture is possible because Christianity in Africa is indigenous, that is, Christianity arose from within African culture, not foreign imposition from without. Recall Bediako's claim that while the missionaries brought the Bible and the name of Jesus Christ, they did not bring the presence or activity of God. Bediako understands much African theology to be describing how God has been active amidst African culture. He writes,

The essential thrust of this first flowering of African theological literature in the twentieth century has therefore been an effort towards indigenization, a rooting of Christianity in African life by claiming for it a past in the spiritual harvests of the African pre-Christian religious heritage. In a curious way, it was indigenization by Christianization of the religious past, rather than by any serious adaptation or contextualization and inculturation - to use two current words - of Christianity as such (CiA, 76).

\footnotetext{
${ }^{89}$ Bediako, "Their past is also our present," 8 .
} 
The movement of the gospel in Africa is from the inside-out. The gospel does not have to be brought to Africa; the gospel has to be discovered within Africa and named as such. God has always been at work in Africa with Africans. Bediako's work articulates the twin heritage of African Christianity, the precolonial African past and the preChristendom Christian past, to demonstrate how the Christian faith arose within Africa rather than being contextualized or inculturated from outside of Africa.

Bediako connects translation to indigeneity through his understanding of the incarnation. He writes:

If it is translatability which produces indigeneity, then a truly indigenous church should also be a translating church, reaching continually to the heart of the culture of its context and incarnating the translating Word. For the Word who took flesh and dwelt among us, not only exegetes (and so translates) God (John 1:18), but also exegetes the human predicament (John 4:29), bringing the two together in a mutually intelligible communication. This makes it all the more important to pay attention to what happens at the level of indigenous assimilation (CiA, 122).

The translation of the gospel into cultural forms is "mutually intelligible communication" that grounds indigeneity in translatability. Because the Word took flesh and dwelt among us, the culture receiving the gospel is valued, not denigrated. The gospel of Jesus Christ - as understood through the translation of Christian scriptures into African mother-tongues - is therefore local and aptly expressed in African concepts and cultural terms. The gospel assimilates — without overcoming —indigenous culture. This process is ongoing and mutually enlightening; teaching about culture and goes hand in hand with an appreciation of the God who reveals.

A comparative perspective is useful at this point. Two of the authors that Bediako analyzed in Theology and Identity, Idowu and Mbiti, offer opposite positions on the question of indigeneity. Both asserted the continuity of ATR with African 
Christianity, yet while Idowu did believe that Christianity could be made to take African cultural forms, he maintained that the Christian gospel was foreign to Africa. ${ }^{90}$ Mbiti believed that the Christian faith is indigenous to Africa. ${ }^{91}$ Idowu forwarded the claim that all African primal religions are monotheistic to demonstrate continuity between ATR and the foreign religion of Christianity. To oversimplify, Idowu argued that since ATR worshipped one God and Christianity worshipped one God that they both must have been worshipping the same God. According to Bediako, "Idowu remained haunted by the 'foreignness' of Christianity, and having started from that foreignness, was never able to arrive at indigeneity" (CiA, 116). The logic of Idowu's argument necessitated postulating monotheism as the continuity even though his claim could not be proven based on the empirical evidence. Idowu understood the multiplicity of "spirits" or “divinities" venerated in traditional religious practices as manifestations of "a single God."92

Although Bediako identifies the claim of continuity as "one of Idowu's most valuable theological insights into African religious tradition" (TI, 288), he instead takes a different tack on the question of monotheism. In Theology and Identity, Bediako had reluctantly agreed with Idowu that ATR is inherently monotheistic. Later he backed off this claim and instead proposed the Trinity as way to understand multiple African divinities so that the one-in-the-many conception of divinity present in African religions can continue. $^{93}$

\footnotetext{
${ }^{90}$ See Bolaji Idowu, Towards an Indigenous Church (London: Oxford University Press, 1965).

${ }^{91}$ See John S. Mbiti, African Religions \& Philosophy 2nd rev. and enl. ed. (Oxford: Heinemann, 1990).

${ }^{92}$ For more on Idowu's position, see Idowu, ATR - A Definition, 205. For more on Bediako's discussion of Idowu see TI, 286-288, and of monotheism in ATR, see TI, 291-293.

${ }^{93}$ Kwame Bediako, "Christian tradition and the African God revisited: a process in the exploration of a theological idiom," in Witnessing to the Living God in contemporary Africa, eds. David Gitari and Patrick Benson, (Nairobi: Uzima Press, 1986), 77-97; and TI, 289.
} 
Mbiti, in contrast to Idowu, understood the Christian gospel as indigenous to Africa and believed that the gospel should be appropriated in African terms. Like Bediako, because Mbiti viewed ATR as praeparatio evangelica for Christianity, Christianity could be understood as a non-Western religion. ${ }^{94}$ Thus, "Mbiti rejected the very idea of the quest for indigenization of Christianity or of theology in Africa" (CiA, 117). Since Christianity was always and already present within African culture, Mbiti rejected the possibility of the indigenization of Christianity or theology. Mbiti objected to Idowu's claim that Christianity was external, foreign to Africa. Bediako shared this objection and further interpreted Mbiti, claiming, "for theology is always indigenous, resulting from the effort to articulate the meaning of the Gospel in a particular cultural milieu in response to the realities of that milieu" (TI, 306). African theology is inherently indigenous — local, authentic, contextual—and cannot be indigenized. Since God in Jesus Christ was active in Africa before any missionaries arrived on the continent, the seeds of the Christian faith were already, inherently, within African culture.

The work of African theology, then, "has been about the redemption of African culture" (CiA, 177). Developments within Africa Christianity and African theology are therefore authentic expressions of the gospel of Jesus Christ, not primarily the result of missionary or ecclesial actions. I repeat this claim because Western Christians (Europeans and North Americans) have had difficulty understanding this point. For Bediako, the ongoing translatability of the gospel is propelled by the activity of God. Bediako understands his claim about the indigeneity of Christianity within African culture to be a direct consequence of the translatability of the gospel. He writes,

\footnotetext{
${ }^{94}$ Significantly, Mbiti also considered Islam to be a traditional African religion.
} 
translatability is the only true basis and starting point for seeking indigeneity. From this perspective, however, indigeneity does not lie at the end of a quest. Rather it is presumed within the very translatability of the Christian religion. Indigeneity is as much a matter of recognition within the Gospel as it is an achievement of actual Christian witness. Thus, universality, translatability, incarnation and indigeneity belong in a continuum and are integral to the warp and woof of the Christian religion. It is only by a serious misconception then that we can call it a Western religion $(\mathrm{CiA}, 123)$.

The gospel is applicable to all people (universality), can be communicated in vernacular languages and concepts (translatability), is based on God assuming human flesh in Jesus Christ (incarnation), and is authentically present within human cultures (indigeneity). This gospel cannot be held captive by any culture. The misconception that Christianity belongs, in some way, to Western culture obscured the essence of Christianity as translatable, and masked its primal substructure.

\section{II.C.ii. \\ Culture: Primal Imagination as the Substructure of African Christianity}

The significance of the spiritual realm in African cosmologies cannot be overestimated, especially for Western readers. Ghanaian philosopher Kwame Gyeke described one African cosmology: "The Akan universe is a spiritual universe, one in which supernatural beings play significant roles in the thought and action of the people. What is primarily real is spiritual." 95 Many Africans believe that what is primarily real is not what is seen, but what is unseen. The spiritual, the spirit world, is the primary reality of human existence; the tangible, visible world is secondary and subservient.

\footnotetext{
${ }^{95}$ Kwame Gyeke, Essay on African Philosophical Thought, 69; quoted in Bediako, Religion, Culture and Language, 8.
} 
Bediako insists on the integrity of "the primal imagination" in his understanding of Christianity (CiA, 92).${ }^{96}$ The primal imagination is understood as an outlook of "a spiritual universe which was both simple and complex, and yet...able to [be] embraced as a totality" (CiA, 92). Further, the maintenance of the primal imagination must derive from ATR; it cannot be imposed from without. ${ }^{97}$ Bediako sees the primal imagination as the core of what is distinctive about African Christianity.

The Christian gospel requires sharing and preserving this view of the primal imagination within African life, not condemning it as many Europeans had. Bediako writes, "Far from obliterating the African primal view of things, in its essentially unified and 'spiritual' nature and replacing it with a two-tier modern Western view comprising sacred and secular dimensions, the Christian faith has in fact reinforced the African view" (CiA, 176). Bediako is thus seeking to "restore the ancient unity of theology and spirituality" (CiA, 105). When he "engages the tradition," he considers the Old and New Testaments and African philosophy, culture and traditions. ${ }^{98}$

In that Bediako constantly seeks to bring together the ancient Christian tradition (including the gospel) with the present context (i.e. African culture), he is selfconsciously following in the line of J.B. Danquah, an author who understood how to link the past with the present, so as to lead on to the future..$^{99}$ The work of translation into and out of African languages and thought-forms further highlights the intersection of gospel and culture. The intended goal is a diminishing of the influences of the Enlightenment

\footnotetext{
${ }^{96}$ Bediako borrows the term from C.G. Baëta's Christianity in Tropical Africa.

${ }^{97}$ Bediako writes: "a starting point for appreciating the primal imagination must be in primal religions themselves" ( $\mathrm{CiA}, 93)$.

${ }^{98}$ In contrast, Barth's understanding of "engaging the tradition" means the last two thousand years of Christian thought as well as the Old and New Testaments.

${ }^{99}$ Bediako, Religion, Culture and Language, 36.
} 
and an increased influence of African religions and culture, particularly of primal religions in the interaction. He writes,

If primal religion is the Christian substructure, then we are researching the foundation of Christian faith. In other words, this project comes with the insight that primal religion is the foundation of the building - Christianity builds on it. For a long time, the Enlightenment project obscured this understanding. The particularity of this moment is that we are persons who are Christian now but are also aware of the primal substructure, which is not to be dismissed as 'pagan.' What we are seeking therefore is a theological interpretation of this Christian substructure. ${ }^{100}$

While Bediako's understanding of “the Enlightenment project” may be a bit of a caricature, there is enough truth in it to demonstrate the stark contrast between the understanding of the world in primal religions and an Enlightenment understanding. The foundation of African Christianity must be African primal religion, not Enlightenment philosophy.

Bediako explicitly refers to this primal religious foundation as the substructure of African Christianity. ${ }^{101}$ If, following Clement of Alexandria, the Christian faith is going to absorb the pre-Christian religion that it encounters, then Bediako is also aware that the prior religion will not merely have an impact on, but be integral to, the Christianity that emerges afterwards. The early Church was deeply influenced by Greco-Roman religion, Christianity in the modern West was deeply influenced by the Enlightenment, and Bediako's argument is that African Christianity is legitimately and valuably determined by African culture and primal religion. (Of course, there remains a more fundamental substructure to Christianity: Israelite cultic religion and second temple Judaism. Yet, the place of Judaism in Bediako's understanding of the Christian faith is much less clear.)

\footnotetext{
${ }^{100}$ Kwame Bediako, "Thoughts on the nature of the project" JACT 11.2 (2008): 4.

${ }^{101}$ Bediako, "Thoughts on the nature of the project," 4.
} 
Bediako's argument concerning primal religions as the substructure of Christianity builds on an understanding of the "primal imagination" that was nearly absent from his discussions of Hellenistic religion in Theology and Identity. At the same time, this appeal to the "primal imagination" complicates Bediako's understanding of history. In Theology and Identity, Bediako's thought was presented in terms of chronological past. Yet, for the later Bediako, although the primal religions of Africa belong to the African religious past, "this is not so much a chronological past as a an 'ontological' past."102 By "ontological," Bediako means that the very being of an African-Christian, or nonChristian — has been indelibly formed by the primal imagination of African spirituality and religion, including beliefs about ancestors. Thus, while many Africans now understand themselves as Christians (or Muslims), they remain indelibly formed in their being and identities as Africans by the primal religions of Africa. In this way, though a smaller percentage of Africans actively practice African traditional religions than before colonization (the "chronological past"), the legacy of the primal imagination continues. The impact of the primal religions remains in the being of Africans. Even when Africans convert to Christianity, they do not, in fact cannot, simply leave the primal religions behind them. Primal religions have shaped who they are and who they will be. Thus, "For the African theologian...the traditional religions, even if they constitute his past, are of the nature of an 'ontological' past, which means that together with the profession of the Christian faith, it gives account of the same entity—namely the history of the religious consciousness of the African Christian" (CiA, 258). The identity of an African Christian is shaped by the past through the influences of pre-Christendom Christian theology and pre-colonial African primal religions. And this twin heritage of African

\footnotetext{
${ }^{102}$ Bediako, "Understanding African Theology," 51. See TI, 4; emphasis added.
} 
Christianity describes the presence of an indigenous Christianity within modern African culture.

Perhaps the clearest example of Bediako's perspective (and an example that foreshadows some of the topics to be addressed later) can be found in his hope for his own Ghanaian Presbyterians. He writes of how every Christmas Day, the Presbyterians in Akropong sing a hymn celebrating Jesus' birthday: “They sing this hymn without any awareness that Christmas itself was originally a Christian substitute for a pre-Christian New Year religious festival in pagan Northern Europe. My earnest prayer and hope is that they will one day sing it at the traditional New Year festival of Odwira to welcome and worship the one who achieved once and for all purification for their sins, their greater Ancestor, Nana Iesu Kristo" (CiA, 86). ${ }^{103}$ Bediako's intent here is to expose and embrace the pre-Christian foundations of many Western Christian traditions, to imagine, positively, how African pre-Christian customs can be embraced in African Christianity.

The impact of the primal imagination, furthermore, keeps African Christianity grounded within everyday realities and not abstracted into the realm of speculative ideas. Bediako writes, a rediscovery of 'primal elements'...may also mean growing into a primal awareness of the Christian Gospel as religion. Primal religions generally conceive of religion as a system of power and of living religiously as being in touch with the source and channels of power in the universe; Christian theology in the West seems, on the whole, to understand the Christian Gospel as a system of ideas (CiA, 106).

Bediako's viewpoint, based in African cosmologies, refuses to separate belief from action, theology from concrete realities. In the end, "Christianity in Africa is a truly

\footnotetext{
${ }^{103}$ In chapter 4, more of Bediako's understanding of Odwira is explored, including how he understands the crucifixion to be the fulfillment of the traditional Odwira festival: "The Odwira to end all odwiras has taken place through the death of Jesus Christ" (JAC, 33).
} 
African experience." ${ }^{104}$ The experiences of Africans—as shaped by the primal imagination within indigenous African cultures that are continuous with Christianity through ATR because of the infinite translatability of the gospel—defines African Christianity. Having considered these prevailing topics within Bediako's work in this section, the following section analyzes their interrelations in his theology of the ancestors.

\section{III.}

\section{A Theology of Ancestors: Interrelationship of Revelation, Religion, and Culture}

The most honored aspect of many African cultures, including the Akan in Ghana, is the place and role of the ancestors. Significant rulers and members of a clan who have died are honored for their life by being designated as ancestors (CiA, 80). ${ }^{105}$ These ancestors are referred to as "the living dead" and form the basis for African Traditional religions. Anthony Ephirim-Donkor defines "African religion, that is, ancestor worship...[as] the continued notion that the ancestors are intimately involved in the affairs of their posterity and therefore the need by the living to worship them in order to receive favor, blessing, and protection from the ancestors and deities." ${ }^{.106}$ Though seeking intervention in everyday affairs and the offering of food and drink in ritual libation ceremonies, ${ }^{107}$ Africans are understood to continually "live with their dead." 108

\footnotetext{
${ }^{104}$ Kwame Bediako, "Cry Jesus! Christian Theology and Presence in Modern Africa," Vox Evangelica XXIII (April 1993), 7-25, and Bediako, "Cry Jesus!" in Jesus and the Gospel in Africa, 9.

${ }^{105}$ For more on selecting ancestors: "not all the dead are ancestors...For ancestors become so not solely by association in blood lineage, but also by quality of life, by the social significance and impact of their work; in other words, the dead become ancestors by achievement in life and not solely for having lived in the community" (CiA, 80).

${ }^{106}$ Anthony Ephirim-Donkor, African Religion Defined: A Systematic Study of Ancestor Worship among the Akan (New York: University Press of America, 2010), v.

${ }^{107}$ Kwame Bediako, "Death and the gospel in the Ghanaian context," Exchange 20:2 (1991): 147.
} 
These honored dead are believed to speak from beyond the grave and influence events on earth.

Bediako's strong desire to integrate what he understands to be the twin heritage of African Christian identity motivates him to address his Christian convictions to the core African religious belief in the ancestors. The question is: how is belief in the ancestors continuous with belief in Jesus Christ? Bediako answers this question in two parts. In so doing, the interrelationship of the three themes that pervade his work-revelation, religion, and culture — is on full display. First, he asserts that Jesus is revealed as an ancestor of Africans and that Jesus has power over the entire spiritual world that is ordinarily attributed to lineage ancestors. Second, Bediako describes how Christianity desacralizes Akan cultural and political convictions. Starting from the conviction that Jesus Christ is the "Universal Saviour" (JAC, 230, emphasis original), Bediako writes that there has been a "continuity of God from the pre-Christian African past into the Christian present...[such that African Traditional Religion was]... a vital preparation for the Gospel" (JAC, 21). This belief in Christ's universality leads Bediako to claim that, "Christianity is, among all religions, the most culturally translatable, hence the most truly universal, being able to be at home in every cultural context without injury to its essential character" (JAC, 32). The analysis in this section will draw on the prior exposition of Bediako's insights about translatability, continuity, indigeneity, and the primal imagination while deepening and complicating Bediako's understandings of revelation, religion, and culture.

\footnotetext{
${ }^{108}$ C.G. Baëta, "The Challenge of African Culture to the Church and the Message of the Church to African Culture" in Christianity and African Culture (Accra: Christian Council of the Gold Coast, 1955), 59, emphasis original. Also cited in CiA, 60.
} 
The African understanding of ancestors lies within, not outside, Christian theology. In Bediako's view, "all Christians in every place and time, not only need to have a past, but indeed do have a past, a pre-Christian past that connects with the present. All Christians have need of ancestors, pre-Christian ancestors!" ${ }^{109}$ Specifically, the ancestors are the most direct link to the African heritage of African Christianity. The stories in the Bible tell Africans of their spiritual ancestors, their predecessors in faith. The Old Testament in particular "validates ... a theology of ancestors" (CiA, 226). At the heart of African traditional religions, the ancestors "represent a more enduring problem theologically than divinities" (CiA, 98). As noted earlier, Bediako applied his understanding of the Trinity to account for the presence of multiple "divinities" with ATR — that he understands as a monotheistic religious system.

For Bediako, the initial focus within African Christian thought on identity, alongside quests to situate African Christianity historically and to pursue the indigenous nature of the Christian faith in Africa through the use of mother-tongue scriptures and vernacular concepts, inevitably led to the development of a theology of ancestors. ${ }^{110} \mathrm{By}$ asserting the "continuity of God in African-experience" (CiA, 225), African theologians needed to interpret "the past in a way which shows that the present experience and knowledge of the grace of God in the Gospel of Jesus Christ have been truly anticipated and prefigured in the quests and the responses to the Transcendent in former times"

\footnotetext{
${ }^{109}$ Bediako, "Their past is also our present," 2.

${ }^{110}$ Bediako is not unique in articulating an ancestor Christology. Though different theologians may use different Christological titles, Bediako sees all of them as seeking to connect African culture with the gospel of Jesus Christ. Bediako wrote: "African Christological titles like 'Eldest Brother' (H. Sawyerr), 'Ancestor,' 'Great Ancestor' (J.S. Pobee, C. Nyamiti, K. Bediako), are neither 'from below,' nor strictly 'from above;' rather they are indicative of the way the primal imagination grasps the reality of Christ in terms in which all life is essentially conceived - as spiritual" (CiA, 176). See Harry Sawyerr, "Ancestor Worship I: The Mechanics" Sierra Leone Bulletin of Religion 6:2 (December 1964), John S. Pobee, Toward an African Theology (Nashville: Abingdon, 1979), and Charles Nyamiti, Christ As Our Ancestor: Christology From an African Perspective (Gweru, Zimbabwe: Mambo Press, 1984).
} 
(CiA, 224-225). These interpretations comprise "a theology of ancestors." Once an African identity in Jesus Christ was established, then investigating the cultural continuity backwards from the present to the past occurred. The question for many Africans was more personal and pointed than the hypothetical questions that many Western Christians ask: "What about the people who were born before Jesus lived? Or what about those who never heard of Jesus? Are they saved?" While Westerners can develop theological responses to account for the salvation of Abraham, Moses, David, Ruth, and the "unreached" peoples of Papua, for Africans in the twentieth century, their relatives, perhaps even their grandparents, may have died before hearing European missionaries explain the gospel of Jesus Christ. What about them? And what about the famed African kings from centuries past who continue to be remembered and revered? Are they saved? Can they be saved?

Beyond these personal and individual questions, broader cultural questions loom large. The deep interconnection of the living and the dead within the Akan people (and many other African peoples) demonstrates a great deal about their understanding of human community and their culture. ${ }^{111}$ Bediako describes the relationship "in traditional Akan understanding, the dead and the prominent dead especially—go to join the ancestors bearing messages from the living." ${ }^{112}$ Those members of the clan who have died who are honored for their life by being designated as ancestors continue to live on from the other side of the grave. ${ }^{113}$ These "ancestors, from the realm of their continuing

\footnotetext{
${ }^{111}$ Bediako comments, "The Ghanaian attitude to death and funeral observances... reveals much about Ghanaian ideas of personal and group security and well-being" (Bediako, "Death and the gospel," 148).

${ }^{112}$ Bediako, "Challenges of Ghana's Fourth Republic," Lecture 2, 13.

${ }^{113}$ See also: "not all the dead are ancestors...For ancestors become so not solely by association in blood lineage, but also by quality of life, by the social significance and impact of their work; in other words, the dead become ancestors by achievement in life and not solely for having lived in the community" (CiA, $80)$.
} 
existence, [are held to] play a decisive role in the affairs of the society." ${ }^{, 14}$ The connection between generations is understood to pass from an ancestor to his descendants. Ghanaian philosopher J.B. Danquah describes this connection as a "spark": "For the Akan central fact of life is not death but life, the means whereby the blood of an ancestor, the spark of the race, is generated for a descendent, bearer and vehicle of the spark." ${ }^{" 115}$ The spirit of life itself is passed from generation to generation through the lineage ancestors. Though death is inevitable and the ancestors are venerated, life itself remains the focus, not fearing nor embracing death.

Bediako approvingly quotes fellow Ghanaian theologian Christian Baëta stating, Africans "live with their dead." 116 Bediako also describes the role and significance of ancestors including the ruler, or chief, of the tribe:

Because the traditional belief is that the well-being of the society depends upon the maintenance of good relations with the ancestors on whom the living depend for help and protection, the ruler fulfills an important function as intermediary between the living and ancestors. The ruler is the central figure at the religious rituals which ensure the maintenance of the desired harmony between the living and the ancestors. In point of fact, in the traditional world view, royal ancestors are not "dead," they have simply joined their grandsires in the realm of the spirit-fathers, from where they continue to show interest and to participate in the affairs of the society through the channels of spiritual intervention by the appropriate rituals. ${ }^{117}$

Frequently, when someone is ill or if the crops are not producing, the first explanation is that the ancestors are unhappy; the first recourse, then, is to find a way to appease them. Thus, the understanding of the place and role of the ancestors within Ghanaian society

\footnotetext{
${ }^{114}$ Kwame Bediako, "Death and the gospel in the Ghanaian context," Exchange 20:2 (1991): 147.

115 J.B. Danquah, The Akan Doctrine of God, 168. Quoted in Kwame Bediako, "Religion and National Identity- Assessing the discussion from Cicero to Danquah Bediako Law and religion - inaugural lecture, June 25, 1997," (Ghana Academy of Arts and Sciences, 2006), 14.

${ }^{116}$ C.G. Baëta, "The Challenge of African Culture to the Church and the Message of the Church to African Culture" in Christianity and African Culture (Accra: Christian Council of the Gold Coast, 1955), 59, emphasis original. Also, CiA, 60.

${ }^{117}$ Bediako, "Challenges of Ghana's Fourth Republic," Lecture 3, 4-5.
} 
cuts to the heart of cultural assumptions and the articulation of an African Christian identity.

According to Bediako, after Danquah's 1944 book, The Akan Doctrine of God, "no African Christian theology that took seriously its African context, could ignore ancestors...[since he] had virtually set the agenda for all subsequent intellectual discourse on the matter." ${ }^{, 18}$ A key concern for Bediako in his understanding of African Christian identity is to prevent and counteract the experience of many African Christians of "living at two levels." Since many African Christians are unable to see how to integrate or reconcile their African cultural heritage with their Christian beliefs they simply hold them both simultaneously, thereby living a bifurcated existence.

Bediako lays the blame for this situation with the churches and their theology not with individual Africans. He writes,

Up to now, our churches have tended to...present the Gospel as though it was concerned with an entirely different compartment of life, unrelated to traditional religious piety. As a result, many people are uncertain about how the Jesus of the Church's preaching saves them from the terrors and fears that they experience in their traditional worldview. This shows how important it is to relate Christian understanding and experience to the realm of the ancestors. If this is not done, many African Christians will continue to be men and women 'living at two levels,' half African and half European, but never belonging properly to either. We need to meet God in the Lord Jesus Christ speaking immediately to us in our particular circumstances, in a way that assures us that we can be authentic Africans and true Christians (JAC, 23).

Bediako argues that the death and resurrection of Jesus exposes the ancestors for what they really are: "the death of Jesus is also the defeat of Satan and of all the elemental demonic terrors which masquerade behind the presumed activity of ancestors." ${ }^{119}$ Since

\footnotetext{
${ }^{118}$ Bediako, "Religion and National Identity," 6.

${ }^{119}$ Bediako, "Death and the gospel," 149.
} 
Jesus "is Lord over the living and the dead, and over the "living-dead" (JAC, 27), ${ }^{120}$ ancestors do not have any real power over the living. Bediako asks: "[A]re not ancestors in effect a projection into the transcendent realm of the social values and spiritual expectations of the living community?" Then, he continues, the "ancestors have no existence independent of the community that produces them....Strictly speaking, the cult of ancestors, from the intellectual point of view, belongs to the category of myth, ancestors being the product of the myth-making imagination of the community" (JAC, 30). Jesus Christ holds spiritual power over all (lesser) spiritual forces. The dead-yetrisen one, Jesus Christ, has power while the dead ancestors do not.

For Bediako, the death and resurrection of Jesus reveals that the ancestors are a myth (JAC, 30). By myth, Bediako means that the ancestors do not possess independent power of their own. ${ }^{121} \mathrm{He}$ writes, "The potency of the cult of ancestors is not the potency of ancestors themselves; the potency of the cult is the potency of myth" (JAC, 30). Belief in the cultural and religious traditions gives the ancestors the appearance of power; intrinsically, lineage ancestors are merely the memories of dead human beings and are thereby powerless. In his death and resurrection, Jesus Christ surpassed the ancestors and replaced the cult of ancestors for African Christians. Only Christ has the power and ability to bestow the benefits believed to be given by lineage ancestors (JAC, 30). Just as each ancestor is believed to remain the spirit of a formerly living human being with his own personality and life experiences, so also for Bediako, Jesus retains

\footnotetext{
${ }^{120}$ Bediako continues: "From the standpoint of Akan spiritual beliefs, Jesus has gone to the realm of the ancestor spirits and the 'gods.' We already know that power and resources for living come from there, but the terrors and misfortunes which could threaten and destroy life come from there also. But if Jesus has gone to the realm of the 'spirits and the gods,' so to speak, he has gone there as Lord over them in the same way that he is Lord over us. He is Lord over the living and the dead, and over the 'living-dead,' as ancestors are also called" (JAC, 27)

${ }^{121}$ Bediako's understanding of myth will be analyzed in greater detail in chapter 4.
} 
his personal identity while in the spiritual realm. In this way, Bediako insists on holding together the person and work of Jesus Christ— just as he would for any ancestor.

Jesus Christ is the only human being who has died who can still have an impact on earthly life. Dead persons honored as ancestors do not, indeed cannot, have an impact on human events; only Christ has authority and power. Bediako is not willing to grant lineage ancestors the power of influential spirits as in African Traditional religions, or even the role of saints in the Roman Catholic tradition. ${ }^{122}$ Bediako challenged the African understanding of ancestral power, "If authority does not reside with the merely human, then why should it be located in the realm of the essentially human spirits of the ancestors? So, in the perspective of Christian ideas, ancestors too become desacralized. Authority truly belongs only to God" (CiA, 244). In the death, resurrection, and ascension of Jesus Christ, God has been shown to be a more powerful spirit, the Great Spirit, than the human spirits of the ancestors. Due to the close connection in African life between ancestral function and politics, particularly tribal politics, Bediako acknowledges that "the whole realm of politics is sacralised...the traditional world-view makes no sharp dichotomy between 'secular' and 'sacred' realms of existence” (CiA, 241). This unified understanding of the holy and the profane in African cosmologies differentiates them from Western understandings. Authority, specifically, belongs to and derives from the transcendent, spiritual realm. The spirits intercede to shape the earthly realities. "Jesus' way of dealing with political power," Bediako wrote, "represents the

\footnotetext{
${ }^{122}$ For a Roman Catholic perspectives see, Edward Fasholé-Luke, "Ancestor veneration and the communion of saints" in Mark Glasswell and Edward Fasholé-Luke, eds., New Testament Christianity for Africa and the World (London: SPCK, 1974) and Nyamiti, Christ as our ancestor.
} 
perfect desacralisation of all worldly power." ${ }^{123}$ The work of Christ asserts his spiritual authority and exposes the ancestors' lack of spiritual authority.

In this way, Bediako can write that "Christianity desacralises, [yet] it does not despiritualise" (CiA, 246). Every challenge to political authority is an attack on the ancestors. ${ }^{124}$ Bediako sees one "of the values of an Ancestor-Christology is precisely that it helps to clarify the place and significance of 'natural' ancestors. ...Just as there exists a clear distinction between God and divinities, so also there exists a qualitative distinction between Christ as Ancestor and natural ancestors" (CiA, 217-218). The clarification that Bediako achieves - that Christ is a unique ancestor and that natural ancestors are merely the common memories of deceased human beings_-places him in conflict with other African understandings of ancestors, both non-Christian and Christian.

Though articulating an ancestor Christology is not unique to Bediako, his formulation remains vulnerable to the critique of African Christianity of failing to regard African Traditional religions on their own terms that is offered by the prominent nonChristian African philosophers, Ali Mazrui and Okot p’Bitek. Other theologians, including South African Tinyiko Sam Maluleke, contested Bediako’s understanding of the ancestors. In "African Traditional Religions in Christian Mission and Christian Scholarship: Re-Opening a Debate that Never Started,” Maluleke accused Bediako of merely viewing ATRs as preparation for Christianity. ${ }^{125}$ Maluleke applied p'Bitek's

\footnotetext{
${ }^{123}$ Bediako, "Challenges of Ghana's Fourth Republic," Lecture 3, 8.

${ }^{124}$ Bediako, "Challenges of Ghana's Fourth Republic," Lecture 3, 5.

${ }^{125}$ Tinyiko Sam Maluleke, "African Traditional Religions in Christian Mission and Christian Scholarship: Re-Opening a Debate that Never Started,” Religion \& Theology 5:2 (1998): 131.
} 
epithet, "intellectual smuggler," to Bediako. ${ }^{126}$ Bediako's approach to the ancestors is found overly triumphalistic. "We must do better," Maluleke wrote, "the possibility is not only for Jesus to become the Supreme Ancestor, but he could simply join the ranks of other ancestors who are at the service of the Supreme Being in Africa." ${ }^{127}$ Maluleke seeks to retain the place of lineage ancestors while exalting Jesus to join them.

While Maluleke criticized Bediako for replacing the cult of ancestors with Jesus Christ, for our purposes, the significance of Maluleke's critique is that he wholly agrees with Bediako that the dead have an impact on the living in African culture. Neither theologian sides with the initial Western viewpoint that the ancestors are demonic, as many early missionaries did. Both offer a positive assessment of African primal religions, even as Maluleke criticizes Bediako's view that ATRs are legitimate religious traditions only as preparation for Christianity. Both affirmed the place and value of ATRs in making significant cultural and religious contributions to the lives of Africans. Bediako appealed to scripture to explore theological and cultural insights that serve to desacralize the ancestors and offer revelation of God in Jesus Christ. A concrete illustration is his method of reading a mother-tongue scripture passage: "He is the image of the invisible God, the firstborn of all creation; for in him all things in heaven and on earth were created, things visible and invisible, whether thrones or dominions or rulers or powers - all things have been created through him and for him. He himself is before all things, and in him all things hold together" (Colossians 1:15-17). For Bediako, in reading and studying this passage in the vernacular Twi version, "the potency of the

\footnotetext{
${ }^{126}$ Maluleke, "African Traditional Religions," 131. For the original use of "intellectual smugglers," see Okot p'Bitek, African Religions in Western Scholarship (Kampala: East African Literature Bureau, 1970), 88 .

${ }^{127}$ Tinyiko Sam Maluleke, "Black and African Theologies in the New World Order: A Time to Drink from our Own Wells," Journal of Theology for Southern Africa 96 (November 1996), 16.
} 
New Testament world of spiritual powers does not seem to be remote at all."128 Specifically, he is interested in the translation of the Greek word $\theta \rho o$ vor, translated into English as "thrones" and into Twi as "nhengua." For the Akan, the Twi-speaking people of Ghana, “" nhengua' are the sacred, ritually preserved thrones of departed royals. As royal ancestors, such departed rulers, [are] presumed [to be] still connected with the community and continuing to be concerned with the affairs of the community." ${ }^{129}$ Most significant is Bediako's conclusion: "By using the term, nhengua, therefore, the Scriptures clearly declare that Jesus Christ reigns supreme over that world also, as living Ancestor there in his own right. ... Jesus Christ has something to do with what happens in the throne room of the royal palace. ${ }^{130}$ Bediako attributes divine authority to the choice of the word, nhengua, in Colossians and takes that usage to assert the authority of Jesus Christ as superior to Akan rulers and ancestors past, present, and future. Bediako reflects on the insight he received from the mother-tongue scriptures, that " $n h e n g u a$ " were created through Christ and were created for Christ, was a revolution and a new revelation!"131 Bediako's understanding of Christ's providential role in history extends over the translation of the Bible from Greek to Twi, the use of nhengua in Akan culture, and the mediating role of the ancestors in Akan religious life.

Based on his underlying belief that the gospel of Jesus Christ is infinitely translatable, Bediako used his understanding of pre-Christendom Christianity and precolonial African traditional religion to shape a history for the Christian faith that is

\footnotetext{
${ }^{128}$ Bediako, "Missionaries did not bring Christ to Africa," 25.

${ }^{129}$ Bediako, "Missionaries did not bring Christ to Africa," 25-26. For more on Akan thrones, or stools, see Peter Sarpong, The Sacred Stools of the Akan (Accra-Tema: Ghana Pub. Corp.,1971).

${ }^{130}$ Bediako, "Missionaries did not bring Christ to Africa," 26.

${ }^{131}$ Bediako, "Missionaries did not bring Christ to Africa," 26.
} 
indigenous to Africa. This indigenous Christian faith can be expressed through mothertongue scriptures and vernacular concepts, including, significantly, a theology of ancestors. Bediako captures the path that we have taken in the following quotation: the cross-cultural transmission did not bring Christ into the local African situation. If there were to be the case, then, in African terms, Christ would be a disposable divinity, actually able to be taken, carried and brought....and presumably also, disposed of if not needed. The deeper insight is, however, that Christ, already present in the situation, called in His messengers so that by proclamation and incarnation, He might be made manifest. The cross-cultural transmission is thus a confirmation of the divine initiative in the local situation, extending its ramifications beyond the range of former horizons, and demonstrating the ecumenical significance of local history (CiA, 226).

The examination of Bediako's theology in this section explored the close interrelationship of revelation, religion, and culture in his thought. For him, God's revelation in Jesus Christ is primary and occurs through the mediums of the Christian scriptures and African traditional religions and cultures. Through his understanding of revelation through the translatability of the gospel, Bediako understands Christ as an ancestor, and seeks to alter traditional understandings of the ancestral cult by placing Christ at the center of African religious life.

\section{IV. \\ Constructive Questions}

Having surveyed Bediako's work and demonstrated the prominence of the three themes of revelation, religion, and culture in his corpus, this final section turns to constructive questions that Bediako addresses. The section proceeds in three parts arguing that A) African Christianity provides models to Western Christians for articulating Christian identity in religiously pluralistic societies, B) African contributions 
demonstrate that Christianity is a non-Western religion, and C) listening to African Christians may change how many Westerners understand the essence of Christianity.

\section{IV.A.}

\section{Religious Pluralism}

Since virtually all Christians around the world live in societies with persons of other religious faiths or of none, ${ }^{132}$ a Christian theology of religious pluralism is a necessity for twenty-first century Christians. Bediako sees that Africa has much to contribute to the development of a theology of religious pluralism while "the modern West has less to offer than may be readily recognized, unless it be the lessons from the disaster that was Christendom." ${ }^{, 133}$ Since for Africans, "pluralism is primarily a lived experience" 134 among Muslims, Christians, and practioners of traditional religions. Thus, Bediako contends that "Christian theology has not had the option, generally speaking, of establishing its categories in isolation, as though in a Christendom in which all possible religious alternatives are presumed to be non-existent, or in a secularized environment in which specifically religious claims are held to be no longer decisive."135 African Christians have always had to consider the claims of primal religions and Islam while understanding and articulating their faith. In particular, since all Africans have been indelibly formed by the primal imagination, the primal cannot be ignored when discussing inter-religious dialogue. ${ }^{136}$ Bediako distinguishes between the context of religious pluralism and the theological agenda of a Christian identity. He writes, for

\footnotetext{
${ }^{132}$ Bediako, "Africa and Christianity on the threshold of the third millennium," 316.

${ }^{133}$ Bediako, "Africa and Christianity on the threshold of the third millennium," 316.

${ }^{134}$ Kwame Bediako, "Biblical Exegesis in the African Context: The Factor and Impact of Translated Scriptures" JACT 6.1 (2003): 20.

${ }^{135}$ Bediako, "Biblical Exegesis in the African Context," 20.

${ }^{136}$ Bediako, "Biblical Exegesis in the African Context," 20.
} 
"modern African theologians, religious pluralism is their experience; Christian identity is the issue" (CiA, 257, emphasis original). ${ }^{137}$ Pluralism is assumed; shaping a Christian identity is the theological task in response to this context. Many Western theologians, whose social contexts are no longer homogeneously Christian, but are increasingly pluralistic, have tried to maintain a prior understanding of Christian identity (and its relationship to culture) in spite of changing circumstances. The "new" pluralism in the West has been "normal" in Africa for centuries. African theologians suggest another way.

As a result of the context of religious pluralism, Bediako views Africa as "the privileged Christian laboratory for the world...the 'normal' African (as other nonWestern) experience of religious pluralism as the framework for Christian affirmation, means that 'Christian uniqueness' or distinctiveness need not be lost in the midst of pluralism." ${ }^{138}$ Bediako asserts the uniqueness of the Christian faith as one option among many, not as an authority ruling over others. Bediako understands the Christian faith in Africa to have preserved its uniqueness and grown exponentially while not seeking religious hegemony. ${ }^{139}$ For Bediako, "a Christian theology of religious pluralism becomes an exercise in spirituality, in which one affirms a commitment to the ultimacy of Christ, whilst accepting the integrity of other faiths and those who profess them."140 He understands a theology of religious pluralism to entail dual, simultaneous,

\footnotetext{
${ }^{137}$ Bediako understands early Hellenistic and African Christian theologians to have had identical an "experience" and "issue" (CiA, 257). For more on Bediako's understanding of the Hellenistic parallels, see "Religion and National Identity," 3.

${ }^{138}$ Kwame Bediako, "The significance of modern African Christianity-A Manifesto," Studies in World Christianity (The Edinburgh Review of Theology and Religion) 1:1 (1995): 62.

${ }^{139}$ Examples to the contrary notwithstanding, including contemporary events in the Central African Republic.

${ }^{140}$ Kwame Bediako, "The unique Christ in the plurality of religions" in The Unique Christ in our Pluralist World, ed. Bruce Nichols (Grand Rapids: Baker, 1994), 55.
} 
affirmations: the uniqueness of Jesus Christ and the integrity of other faiths. These affirmations are to be maintained "in Christ-like humility and vulnerability."141

African theologians who were trained in the West were "forced by the very demands of Africa's religious pluralism, to move into areas of theological activity for which no Western syllabus prepared them" (CiA, 258), according to Bediako. ${ }^{142}$ Their theological activities attest to what Bediako has claimed on a number of occasions: that Africa is a Christian theological "laboratory for the world" (CiA, 252). ${ }^{143}$ More generally, Bediako claims that the recent history and present realities of Christianity in Africa allow for "experiments" that are instructive for the wider world and for the future of Christianity. Bediako's central contention is that the setting of Christianity in Africa has always been religiously pluralistic. ${ }^{144}$ From the beginning "in modern Africa, the Christian churches have had to learn to evangelize, grow and affirm that Jesus Christ is Lord in the midst of other religious options, notably the pervasive spiritualties of both the indigenous primal religions and Islam."145 The work of African theologians in shaping a distinctive Christian identity in religiously pluralistic societies can be a guide to Western theologians facing a similar task. To do so, however, Bediako claims that Western theology must be fundamentally re-made.

\footnotetext{
${ }^{141}$ Bediako, "The unique Christ in the plurality of religions," 55. See also, "Islam and the Kingdom of God," 6.

${ }^{142}$ Also in Bediako, "Understanding African Theology in the twentieth century," in Jesus and the Gospel in Africa, 52.

${ }^{143}$ See also CiA, 265; Bediako, "In the Bible...Africa walks on familiar ground" AICMAR Bulletin 6 (2007): 34; and Bediako, "Types of African Theology," 56.

144 "Long before pluralism - religious as well as cultural-became a subject of serious discussion in the Western world, many of the Christian communities of Africa had been living, witnessing and learning to survive and grow in the context of religious pluralism" (TI, 433).

${ }^{145}$ Bediako, "Islam and the Kingdom of God," 3.
} 


\section{IV.B.}

\section{Re-making a non-Western religion}

For Bediako, one of the main problems in Christendom was the elimination of religious pluralism and the concurrent equation of Christianity with culture.

Alternatively, he understood Christianity as a non-Western religion: "This is not to say that Christianity has ceased to exist in the West, but simply that the faith and its expression are no longer determined by dominant Western cultural and social norms."146 For nearly seventeen hundred years, Western Christianity has operated as if it was the center of worldwide Christianity. Not only is there "no one centre from which Christianity radiates," Bediako claims that "it was never intended to be so" (CiA, 164). There has therefore been a shift from the perceived center of Christianity in Europe to multiple centers, a development Bediako calls, "the emergence of a positive polycentrism, in which the many centres have an opportunity to learn from each."147

The theme of multiple centers, leading to multiple "Christianities," was present in Bediako's work from his earliest writings to his last major lecture. In 1984, Bediako noted that in the twentieth century, "The missionaries were completely unaware that there could be other "Christianities" than the form they knew. This problem persists right up to our day."148 Thus, not only were the missionaries mistaken in presuming their understanding of Christianity was the only possibility, but Western Christianity has not learned any different in the ensuing hundred years. Even while a graduate student in Aberdeen, Bediako concluded that "the sheer number of African Christians makes it

\footnotetext{
${ }^{146}$ Bediako, "'In the Bible...Africa walks on familiar ground.': Why the World needs Africa” AICMAR Bulletin 6 (2007): 36.

${ }^{147}$ See Kwame Bediako, "Whose Religion is Christianity?'” JACT 9:2, 2006; and Kwame Bediako, "Conclusion: The Emergence of World Christianity and the Remaking of Theology," Understanding World Christianity: The Vision and Work of Andrew F. Walls eds. William R. Burrows, Mark R. Gornik, and Janice A. McLean (Maryknoll, NY: Orbis, 2011), 248; Also published in JACT 12.2 (2009).

${ }^{148}$ Bediako, "Biblical Christologies in the context of African Traditional Religion," 121.
} 
difficult to ignore what African theologians say and write."149 Yet his real concern lay with the future of the Church worldwide as a result of "the increasing intellectual stiffening of African Christian conviction."150

As the Christian faith comes to be understood more and more as a non-Western religion, Bediako understands and appreciates that a number of tangible changes will be vital. Foremost among these changes is the "considerable...intellectual adjustment" necessitated to consider the extent that Christianity "has now ceased to be shaped primarily by the events and processes at work in Western culture."151 The intellectual adjustment then "requires nothing less than the complete rethinking of the Church history syllabus" (CiA, 207). ${ }^{152}$ Here Bediako is quoting Walls and perhaps thinking of John Mbiti's famous quotation that Western Christians know more about the heretics of the second and third centuries than about contemporary Christians living in the developing world: "We feel deeply affronted and wonder whether it is more meaningful theologically to have academic fellowship with heretics long dead than with the living brethren of the Church today in the so-called Third World." ${ }^{\prime 153}$ Africa and other parts of the developing world ought no longer be seen as destinations for missionaries. Rather the Christians in these lands are potential teachers and collaborators in the work of the Kingdom of God.

\footnotetext{
${ }^{149}$ Kwame Bediako, "Review of African theology en route" in Journal of Religion in Africa 11:2 (1980): 159.

${ }^{150}$ Bediako, "Review of African theology en route," 159.

${ }^{151}$ Bediako, "Africa and Christianity on the threshold of the third millennium," 307.

${ }^{152}$ Bediako is quoting Andrew Walls' article in International Bulletin of Missionary Research 15:4 (1991): 146.

${ }^{153}$ John Mbiti, "Theological impotence and the universality of the Church" Mission Trends No.3: Third World Theologies, Gerald Anderson and Thomas Stransky, eds. (Grand Rapids: Eerdmans, 1976), 17. Cited in CiA, 154.
} 
Bediako perceives "the significant cultural crossings of the Christian gospel"154 that are today taking place in the churches of the global South and in Africa in particular. These crossings allow for three observations regarding "the reorientation that is needed for embracing the task of theology afresh in our time...first, a recovery of the religious dimension to theology which can provide a confident basis for courageous Christian witness amid religious pluralism; second, the recognition of the critical importance of the living church for doing theology; and third, a recovery of spirituality in theology. ${ }^{1155}$ By attending to religious pluralism, the critical importance of the living church, and a recovery of spirituality in theology, African Christian theology can help to provide answers to the questions that are being asked in Western contexts, but which the West has not recently considered. Thus, in "the remaking of theology in our time, the Christian churches and scholars of Africa, and also of the other Christian heartlands in Latin America, Asia and the Pacific, are called upon to lead the way."156

The change in role for African Christian theologians - from the earliest stages of seeking an African Christian identity to now leading the way for the re-making of Christian theology worldwide - transforms Bediako's understanding of the African theologian's task. African Christian theological scholarship

is no longer merely for Africa. It is for the world, which means that it cannot narrow its focus on Africa for its inspiration. African Christian scholarship is now drawn, through the very process of mission, into the heritage of the whole church, from its apostolic foundations. African theological scholarship can ill afford any short cuts, and it must resist the temptation to succumb to them. Unless, in seeking 'how the Gospel will touch Africans most deeply,' African theological scholarship embraces

\footnotetext{
${ }^{154}$ Bediako, "The emergence of world Christianity and the remaking of theology," 51.

${ }^{155}$ Bediako, "The emergence of world Christianity and the remaking of theology," 51.

${ }^{156}$ Kwame Bediako, "The emergence of world Christianity and the remaking of theology," 54.
} 
and enters into 'the whole heritage of the whole church,' it may contribute less than it could to the wider body of Christ. ${ }^{157}$

The growth of African Christianity and the concurrent process of globalization (and reverse globalization) have offered a new role to Africans within the worldwide Christian community. For the next stage, African theologians will lead and others will follow.

The shift to a non-Western Christianity also leads "a reverse process to the prevailing Western-driven globalization...[a] process of globalization 'from below.",158 These mutually reinforcing processes - as the former theological centers in the West and the emerging centers in the developing world both produce theological contributionsestablish that a monolithic cultural expression of Christianity is not possible, and that in fact it never was.

\section{IV.C.}

\section{World Christianity(-ies)}

The presence of a vibrant and growing African Christianity gave Bediako the confidence to claim in his last major lecture in July 2007 that

in the present situation, it becomes less helpful to speak of a 'global Christianity' whereby, presuming a contest for 'global' hegemony, the new centres of Christian vitality are represented as 'the next Christendom' - a relocation of power from Western churches, and therefore a global threat to the West (pace Jenkins' Next Christendom). Rather, it is more helpful and indeed more accurate, to recognise the emergence of a 'world Christianity', the result of diverse indigenous responses to the Christian faith in various regions of the world. ${ }^{159}$

\footnotetext{
${ }^{157}$ Bediako, "The emergence of world Christianity and the remaking of theology," 54.

${ }^{158}$ Bediako, "Africa and Christianity on the threshold of the third millennium," 314.

${ }^{159}$ Bediako, "The emergence of world Christianity and the remaking of theology," 248.
} 
For Bediako, there are multiple centers of Christianity in the world, not just one and certainly not just one in the West. ${ }^{160}$ And this reality suggests an opportunity for the developing world to help the West. In fact, Bediako states his conviction even more strongly. As a graduate student, he had written, "it may well require a more active partnership with Third World churches to effect the rescue of Western churches from their captivity to culture.”161 This quotation lays bare Bediako's central claim about Western Christianity: its captivity to culture. For him, the West has traded the good news of the gospel for a poor substitute. Instead of the church placing its foundation on the unchanging gospel of Jesus Christ, the Western churches have placed their confidence in the shifting sands of culture. For Bediako, the gospel of Jesus Christ does not change, but its cultural form must change as the gospel is translated from one host culture to the next. The result of Bediako's claim is that "all Christian theology is a synthesis, an 'adaptation' of the inherited Christian tradition in the service of new formulations...no Christian theology in any age is ever simply a repetition of the inherited Christian tradition" (TI, 434). As a synthesis, the timeworn category of syncretism is revealed as hollow (see more on syncretism in chapter 4). Bediako does not give up on the term, he still seeks "relevance without syncretism," yet also seeks an understanding of Christianity that is "a synthesis."

For Bediako, the considerable intellectual adjustment of a non-Western Christianity and the process of reverse globalization encourage and demand a

\footnotetext{
${ }^{160}$ Bediako, "New paradigms on ecumenical co-operation: An African perspective," International Review of Mission (July 1992): 376.

${ }^{161}$ Bediako, "The Willowbank Consultation," 32.
} 
universalizing in reverse. ${ }^{162}$ Since the gospel is universal and applies everywhere, the gospel can be translated from Greek and Hebrew and understood in Africa as God speaks in every tongue. Then, once understood in Africa, the implications for the meaning of Christianity worldwide can be universalized as a non-Western religion. Bediako's articulation of this claim relies on Revelation 7:9: "After this I looked, and there was a great multitude that no one could count, from every nation, from all tribes and peoples and languages, standing before the throne and before the Lamb, robed in white, with palm branches in their hands." He writes,

though Christianity has always been universal in principal it can be seen to have become universal in practice only in recent history in fact. Now this, of course, is a fact that is not only unique among the world's religions, it is a new feature for the Christian faith itself. One must not under estimate, therefore, what the outworking of a global, Christian identity might involve. ${ }^{163}$

As Christianity moved from being theoretically applicable worldwide to manifesting diverse forms throughout the world, Bediako expanded beyond only trying to establish and articulate an African Christian identity toward "a global, Christian identity." Yet, it must be noted, that even a broader Christian identity is not abstract, somehow apart from a host culture(s). Instead, as always, this universalizing from the bottom-up, or at least from Africa to the world, must be particular.

Bediako does believe that African Christianity has something unique to offer to the conversation about universality. He writes, "in order to understand Christianity as a religious faith, one needs to understand African Christianity...African indigenous

\footnotetext{
${ }^{162}$ In her 1966 poem, “Colonization in Reverse," Jamaican Louise Bennett described a similar phenomenon. The final stanza of the poem reads: "What a devilment a Englan!/Dem face war an brave de worse;/But ah wonderin how dem gwine stan/Colonizin in reverse" (Louise Bennett, Selected Poems (Kingston, Jamaica: Sangster's Book Stores, 1982), 107).

${ }^{163}$ Bediako, "Reading Signs of the Kingdom" (Stone Lecture \#1, Princeton Theological Seminary, Princeton, NJ, October 20, 2003).
} 
knowledge systems may have something to contribute here in their holistic, integrating and reconciling nature, and their profound tolerance of diversity. African indigenous knowledge systems could become a positive resource in a new polarized world." ${ }^{164}$ In this "New Era in Christian History," Africa can help Christianity to connect with the primal substructure of the Christian faith and to positively engage the religiously pluralistic contexts of the twenty-first century world.

My comprehensive analysis of Bediako's corpus demonstrates how Bediako's act of theological négritude articulates an African Christian identity by recovering an African Christian past. The major topics of Bediako's writings (translatability of the gospel, continuity of Christianity with ATR, indigeneity of Christianity in Africa, and the primal imagination) manifest three recurring theological themes-revelation, religion, and culture. The examination of these themes, individually and collectively provide a bridge for examining the relevance of Bediako's thought to contemporary questions in constructive theology.

Prior to constructive engagement with these three themes, chapter 3 explores their prominent roles in Barth's mature Christology. Subsequently in chapter 4, revelation, religion, and culture are brought into a more focused comparative and constructive dialogue between Bediako and Barth.

\footnotetext{
${ }^{164}$ Kwame Bediako, "A New Era in Christian History-African Christianity as Representative Christianity: Some Implications for Theological Education and Scholarship" JACT 9.1 (2006): 4.
} 


\section{Chapter 3 \\ Karl Barth: The Ongoing Prophetic Activity of Jesus Christ}

Jesus Christ is not only the High-priest and King but also the Prophet, Herald and Proclaimer of this accomplishment...He exists in this special form of His history (Geschichte). Hence in this third form too, as a doctrine of Jesus Christ the true light, Word and Revealer, as a doctrine of His prophetic office, Christology is a narration (Erzählung) of His history, and specifically a narration of the shining of His life, the real speaking of the covenant, the revelation of reconciliation, in other words, the action (Tun) of the Prophet Jesus Christ (IV.3, 165-166 rev./189). ${ }^{1}$

The themes of revelation, religion, and culture that arise from a comprehensive analysis of Bediako's corpus set the agenda for the rest of the dissertation. In this chapter, these same themes are analyzed from the perspective of Karl Barth, a European theologian writing during and after the "shattering events" (IV.3, 30/30) of the twentieth century - two world wars, the Nazi Holocaust, atomic warfare, independence movements in colonized nations, and the Cold War between rival political and economic systems. Barth's late Christology, in IV.3, §69-The Glory of the Mediator-has been chosen for examination specifically because of its overlap with Bediako's theological emphases. Barth's account of the ongoing prophetic activity of Jesus Christ provides a useful comparison to Bediako's understanding of the "translatability of the gospel of Jesus Christ.”

Barth envisioned "a deep shadow"(IV.3, 19/18) as having fallen upon the Church

\footnotetext{
${ }^{1}$ Quotations from Karl Barth, Die kirchliche Dogmatik (13 part volumes; Munich: Chr. Kaiser, 1932 and thereafter Zürich: EVZ, 1938-1965); ET: Church Dogmatics (13 part-volumes; ed. G.W. Bromiley and T.F. Torrance; Edinburgh: T\&T Clark, 1956-1975); will be cited parenthetically within the text as follows: (part-volume, page in Church Dogmatics/page in Die kirchliche Dogmatik), i.e. (IV.3, 165/189). The citation 'rev.' indicates a revised translation. Unless otherwise noted, boldface-type with these quotations indicates Barth's emphasis that may or may not have been reproduced in the English translation.
} 
in the years following the Reformation. ${ }^{2}$ Preceding and continuing through this deep shadow, Barth perceives the shining of the "Light of Life," the God-man Jesus Christ. Barth's usage of the imagery of "light," "life," and "darkness" echoes the prologue to the Gospel of John: "In him was life, and the life was the light of all people. The light shines in the darkness, and the darkness did not overcome it" (John 1:4-5; IV.3, 9/7, 167/191). Barth in IV.3 described the diastasis, or rupture, that he observed between the Christian community on earth and its beginnings in the life, death, resurrection, and ascension of the God-man Jesus Christ, as a response to "the question of the responsible explication and application of the Word of God attested in Scripture" (IV.3, 32/33-34) that failed to assert "the sovereignty of the word of Scripture over all man's self-understanding" (IV.3, 32/33). In the modern period, Christians had turned the faith into a religion that was based on abstract principles and not on the person of Jesus Christ. Barth seeks overcome this rupture through a consistent focus of attention upon the actions of Jesus Christ, understood as history.

The life, death, resurrection, and ascension of Jesus Christ illuminate who God is (as God's self-revelation) and proclaim God's reconciliation for all. Thus, Barth's oftrepeated phrase, "Reconciliation is also revelation" (IV.3, 38/40). ${ }^{3}$ With these words, Barth succinctly articulates his actualistic understanding of revelation as coextensive with, and in some way identified with, God's redemptive activity. Humans know who God is in and through God's action in the world in Jesus Christ. And this proclamation of

\footnotetext{
${ }^{2}$ In his 1894 Christmas Eve sermon, "The Light of the World," Christoph Blumhardt described "the shadow which is cast over all Christendom" as a result of Christianity's selfish exploitation of "these sublime words - 'come into the flesh, come into the world.'" in Christoph Blumhardt and his message, R. Lejeune, ed. (Rifton, New York: The Plough Publishing House, 1963), 137.

${ }^{3}$ Barth pairs "reconciliation" and "revelation" twenty-nine times in IV.3, §69.
} 
Jesus' life is "eloquent and radiant" (IV.3, 79/87) ${ }^{4}$ communication to those who have ears to hear and eyes to see that God is for humanity in the past, present, and future. ${ }^{5}$ The life of Jesus Christ is a life of grace and offers a life of grace to all humanity. This grace "would not be grace if it were to remain mute and obscure...or were not eloquent and radiant. As such, it is eloquent and radiant. As such, it is prophecy" (IV.3, 81/90). ${ }^{6}$ The present chapter examines Barth's exposition of the ongoing prophetic activity of Jesus Christ. $^{7}$

\section{I.}

\section{The Prophetic Office of Jesus Christ}

In IV.3, §69, Barth's exposition of the ongoing prophetic activity of Jesus Christ articulates his understanding of reconciliation as revelation: the work of Christ as prophet proclaims the justifying and sanctifying work of Christ as Priest and King. This chapter does not offer a comprehensive treatment of Barth's work, or a wholesale comparison of Bediako and Barth. Instead, it presents Barth's views on the three themes that emerged from Bediako's corpus as central to the task of theology today: revelation, religion, and culture. In the interest of providing some context and interpretive clarity, the chapter will, however, situate $\S 69$ within Barth’s corpus and explore other pertinent parts of his Church Dogmatics. Further, in the process of explication, a number of unexpected

\footnotetext{
${ }^{4}$ The initial use of der sprechende, der leuchtende Gott, literally "the talking, shining God," is in IV.3, 79/87. In the Church Dogmatics, the phrase "eloquent and radiant" appears eight times, all within three pages in $\S 69$. See IV.3, 79/87-three uses, 80/88, and 81/89-three uses.

${ }^{5}$ See again Christoph Blumhardt's 1894 Christmas Eve sermon, "Jesus is the light of the world...He will come in radiance over all peoples of the earth," in Christoph Blumhardt and his message, 141-2.

${ }^{6}$ For more on the use and meaning of "eloquent and radiant" in $\S 69$, see John Webster, "Eloquent and Radiant': The Prophetic Office of Christ and the Mission of the Church," in his Barth's Moral Theology: Human Action in Barth's Thought (Grand Rapids: Eerdmans, 1998), 125-150.
} 
theological convergences emerge between Bediako's work and Barth's $§ 69$ and prepare the way for the direct comparison in the next chapter.

Specifically, in what follows I argue that Barth's understanding of Christ's ongoing prophetic activity intersects with the three theological concerns expressed by Bediako. Christ's ongoing prophetic activity: 1) enables universal revelation for all, 2) pervades culture (through parables of the Kingdom of Heaven), and 3) redefines religion. Little more will be said of Bediako in this chapter.

The argument unfolds in five sections. The first offers an orientation to $\S 69$, the imagery of Prophet in Barth's work, and Barth's understanding of history (Geschichte). The second section, "Revelation," explores how Barth's use of the imagery of Jesus Christ as the Light of Life demonstrates Barth's claim that all revelation is God's selfrevelation. This revelation, as "eloquent" and "radiant," is for all people and cannot be captured in a worldview. Further, revelation is ongoing. The third section, "Culture," considers the way in which revelation occurs within human cultures, including outside the Christian scriptures or the Church. Cultures function as mediums, or vehicles, of Christ's ongoing prophetic activity. This discussion of the revelatory possibilities of "parables of the Kingdom of Heaven" in $§ 69.2$ also leads into an analysis of Barth’s use of the terms "secular" and "periphery" in §69. In the fourth section, 'Religion,' the prophetic thrust of Barth's Christology is used to examine his treatment of Ludwig Feuerbach and to offer a re-reading, in light of the material claims in $\S 69$, of Barth's earlier work on religion in Church Dogmatics I.2, §17—“'On the Sublimation (Aufhebung) of Religion.” Barth's later work focuses on the person of Jesus Christ-

\footnotetext{
${ }^{7}$ For more on Barth's understanding of Christ as prophet, see Georg Pfleiderer, "Das 'prophetische Amt' der Theologie: Zur systematischen Rekonstruktion der Theologie Karl Barths und ihres
} 
alive, risen, and ascended — not any principle of Christianity or the Christian religion;

Christ's ongoing revelatory action as the Light of Life that enkindles human lives cannot be captured by static concepts. The fifth, concluding section of the chapter, explores the implications of Barth's understanding of the ongoing prophetic activity of Jesus Christ.

\section{I.A.}

\section{Church Dogmatics IV.3, §69}

Church Dogmatics IV.3 was published in German in 1959 and in English in 1961, following its debut as student lectures at Basel in the winter term of $1956-57 .{ }^{8}$ Geopolitically, the context of the composition of $\S 69$ is the Cold War. The first lectures on "The Glory of the Mediator" were delivered in late 1956 (the year of Barth's seventieth birthday), just weeks after the Hungarian Revolution and Soviet occupation. A year prior, the Warsaw pact had been created and Germany had joined the North Atlantic Treaty Organization (NATO). A year later, the Sputnik satellite was launched by the Soviet Union beginning the space race with the United States.

In the opening sub-section of $\S 69$, Barth described how increased secularization in Europe demonstrated the diastasis, or rupture, present between contemporary Christian communities and the God-Man Jesus Christ (IV.3, 20-21/19-21, 32/34). European churches had turned inward to fortify themselves against what many perceived to be a hostile outside world. These communities seemingly lacked the ability, interest, and theological rationale to engage the world around them. Their only outward focus

Entwicklungsgangs," Zeitschrift Für Dialektische Theologie 17:2 (January 2001): 112-138.

${ }^{8}$ Eberhard Busch, Karl Barth, 425. IV.3 was completed with the lectures of winter 1958-59 (see Busch, Karl Barth, 441). IV.3 was published in two parts because of its length, 1107 pages in German, 963 pages in English. Barth wanted to make sure that the reader received "two halves that were 'bearable' ('tragbare') in the literal sense" (IV.3, preface, xi/Vorwort). 
involved supporting foreign missions to other people who needed to know of Jesus

Christ. Barth, however, was unwilling to abandon educated Europeans. In IV.3, he turned to Calvin's rediscovery and codification of the munus triplex (Christ's threefold office) and used the motif of prophecy to present a reconsideration and renegotiation of the frontiers of Church/world and sacred/secular (IV.3, 35/37). ${ }^{9}$ He argued specifically that Christians ought to understand the prophetic office of Christ that shines the light that gives life to all people as an occasion to consider revelation in an expansive way. In the best-known portion of $\S 69$, Barth presents his view of "parables of the kingdom" that, at times, are forged by God to proclaim true words outside the Church or the Bible (IV.3, 114-135/128-153). Barth refuses to offer any examples of these true words (or parables of the kingdom), yet emphatically states that true words do happen (IV.3, 135/152). This

\footnotetext{
${ }^{9}$ See John Calvin, Institutes of the Christian Religion, II.xv. 1-2. Yet as Geoffrey Wainright helpfully notes, "Calvin was not the first sixteenth-century writer to take up the notion of Christ's threefold office: there are scattered anticipations of his more developed use. Already in his Commentary on the Second Psalm (1522), Erasmus speaks of the senseless raging of the prince(s) and peoples of this world against the Lord and his Anointed when in fact Christ has come, full of grace, for the salvation of all nations: "the prophet of prophets, the priest who has given himself" (Wainright, For our salvation: two approaches to the work of Christ (Grand Rapids: Eerdmans, 1997), 103). Wolfhart Pannenberg insightfully identifies that Calvin may have seen Osiander's use of the munus triplex in 1530. He writes, "Luther was not the author of the doctrine of the three offices in the Reformation. Luther spoke only of the Kingship and Priesthood of Christ. The figure three (sic) seems to go back to Andreas Osiander. In his defense written for the Augsburg Reichstag of 1530 he gave the argument, which later became classic, for the necessity of speaking of three offices — or better, of a threefold office — of Christ: 'Since Christ is thus called an Anointed One and only the prophets, kings, and high priests were anointed, one notes well that all three of these offices rightly belong to him: the prophetic office, since he alone is our teacher and master, Matt. 23:8 ff.; the authority of the king, since he reigns forever in the house of Jacob, Luke 1:32 ff., and the priestly office, since he is a priest forever after the order of Melchizedek, Ps. 110:4. Thus it is his office that he is our wisdom, righteousness, sanctification, and redemption, as Paul testifies in 1 Cor., ch. 1.' The threefold character of the offices of Christ achieved general recognition through Calvin, who had used the doctrine after 1536 in the Geneva Confession and in the various versions of the Institutio Christianae Religionis. Apparently the subsequent Reformed, as well as Lutheran, orthodoxy took over the doctrine of the three offices from him" (Pannenberg, Jesus: God and Man, tr. Lewis L. Wilkins and Duane A. Priebe (London: SCM, 1968), 213). Pannenberg found Osiander's defense in Wilhelm Gussman, Quellen und Forschungen zur Geschichte des Augsburgischen Glaubensbekenntnisses vol. 1 (Leipzig and Berlin: B.G. Teubner, 1911), 302.

Both Erasmus and Osiander, however, were not inventing, but recovering, the concept of the threefold office from the early church. Eusebius, in his Ecclesiastical History from the early fourth century, described the three offices as follows: "...so that all these have reference to the true Christ, the divinely
} 
affirmation of extra-ecclesial words challenged long-held assumptions by claiming a higher authority than the religious establishment and its leaders. Barth does not want people to have stable criteria that could be used to imprison a Biblical text and evade the reality of God; ${ }^{10}$ he wants to acclaim God's freedom to communicate with humankindnow "in many and various ways" (Hebrews 1:1).

Barth suspects that there is something wrapped up with the prophetic office that "a modern theology cannot ignore because it is inescapably presented to it in the destinies, happenings and forms of the modern Church" (IV.3, 18/18). He understands the rediscovery of the prophetic office of Christ at the time of the Reformation as no accident or coincidence (IV.3, 38/40). ${ }^{11}$ The Church reoriented itself outwards (IV.3, 35/36), just as the world turned from the Church (IV.3, 37/39). At this point, the boundary between the sacred (the Church) and the secular (everything else) blurred.

Barth was not alone in this analysis of the state of Christianity in Europe. By the 1900s in Germany, Barth's teacher, Adolf von Harnack, described how the Church had lost its position in society. In What is Christianity? Harnack sought to demonstrate "the leading changes which the Christian idea has undergone in the course of its history." Harnack's image for these changes is one of husks that hold the kernel of the Christian

inspired and heavenly Word, who is the only high priest of all, and the only King of every creature, and the Father's only supreme prophet of prophets" (1.3.8).

${ }^{10}$ Barth earlier articulated this concern in his Epistle to the Romans, 8-9.

${ }^{11}$ For more on the history of the munus triplex, see Wolfhart Pannenberg, Jesus: God and Man, tr. Lewis L. Wilkins and Duane A. Priebe (London: SCM, 1968), 212-25; Wolfhart Pannenberg, Systematic Theology vol. 2, trans. Geoffrey Bromiley (Grand Rapids: Eerdmans, 1991), 444-449; John Frederick Jansen, Calvin's Doctrine of the Work of Christ (London: J. Clark, 1956), 13-38; Gerald W. McCulloh, Christ's Person and Life-Work in the Theology of Albrecht Ritschl with Special Attention to Munus Triplex (Landham, MD: University Press of America, 1990), especially chapter 3: "The History of Munus Triplex in Christian Thought," 86-144; and David T. Williams, The Office of Christ and its Expression in the Church: Prophet, Priest, King (Lewiston, NY: Edwin Mellen Press, 1997).

${ }^{12}$ Adolf Harnack, What is Christianity? trans. Thomas Bailey Saunders (New York: Harper \& Brothers, $1957[1900]), 15$. 
faith in different eras. ${ }^{13}$ Ironically, given their disagreements in the 1920s, Harnack and Barth, both seek a return to the kernel of the Christian faith that has become deeply hidden within the culture of European Protestantism (Kulturprotestantismus) — though Barth would not use such language. As Barth sees it, the European Church in the twentieth century faced a difficult choice. The Church "might try to fight for the maintenance or restoration of its vanishing respect and influence," or it might "retreat to the reservations of a self-satisfying religiosity," or "it might accept the increasing secularism on an optimistic interpretation" (IV.3, 19-20/19). Barth opts for the third option, intending his Dogmatics: "to offer to the adult (mündig) world a suitably adult (mündig) form of Christianity" (IV.3, 19-20/19). ${ }^{14}$

According to Barth, the failings of nineteenth century European Christian thought reached their nadir in liberal Protestantism, first in the endorsement of the German warmachine in the 1910s and again in the German church struggle (Kirchenkampf) of the 1930s. On behalf of the Confessing Church's attempts to resist the Nazi-sympathizing Deutsche Christen, Barth largely wrote the Barmen Declaration in 1934. Barth used the first article of that declaration twenty-five years later as the thesis of IV.3, §69, “The

\footnotetext{
${ }^{13}$ Harnack used the kernel and husk imagery on pages 2, 12, 15, 55, 179, 217, and 299.

${ }^{14}$ In the Church Dogmatics, Barth first uses mündig, meaning maturity or coming-of-age, in I.2 (335/367), then it was furthered developed by Dietrich Bonhoeffer (through the influence of Wilhelm Dilthey's work) in his Letters and Papers from Prison: letters to Eberhard Bethge on June 8, 1944 (427), July 16, 1944 (478-9), July 18, 1944 (482), and August 3, 1944 (500). Barth notes two ironies of this position. The first irony is that in the sixteenth century, as the Church turned toward the world, the world turned away from the Church (IV.3, 37/39). Second, as Christianity regressed in Europe, following the Reformation, began "an age of unparalleled Christian missions...modern Christianity, externally attacked and constricted... engaged in an original and spontaneous outward movement" (IV.3, 23/23). The external pressures marginalizing the influence of the Church in Europe, led to an internal compulsion among Christians to expand the reach of their faith to the "newly discovered" lands of Africa and the Americas. Barth praises the work of organizations like the Basel Mission (IV.3, 25/25) while indicating that colonialism, offered "vexatious hindrance instead of help" to the colonized peoples and to the spread of the gospel of Jesus Christ (IV.3, 26/26). For more on the relationship of Bonheoffer to IV.3, see Charles Marsh, Reclaiming Dietrich Bonhoeffer: The Promise of his Theology (New York: Oxford University Press, 1994), 25-33 and 48-50.
} 
Glory of the Mediator": "Jesus Christ as attested to us in Holy Scripture is the one Word of God whom we must hear and whom we must trust and obey in life and in death" (IV.3, 3/1). Immediately, a number of themes of this part-volume are displayed: hearing, trusting, and obeying the one Word of God who is attested in Holy Scripture as Jesus Christ. The theme of revelation pertains to how one hears and knows what God is saying or showing; the theme of culture pertains to the context within which hearing, trusting, and obeying occurs; and the theme of religion pertains to the corporate "we" as a reminder that hearing, trusting, and obeying do not take place alone, but, in relation to, others. These are the elements that comprise an adult form of Christianity that might confront a church that has lost its connection to its origins.

Before progressing further, we will pause to define these three terms-revelation, religion, and culture - as Barth would have us understand them. Barth is most explicit in his Dogmatics about offering definitions of revelation and religion, less so of culture. For Barth, revelation is Jesus Christ, specifically the actions of Christ that are narrated in a history recorded in the Old and New Testaments (IV.3, 165-166/189). Barth explicitly addresses religion in I.2, §17—“"The Revelation of God as the Sublimation (Aufhebung) of Religion." In the thesis statement of that paragraph, Barth defines religion as "the realm of attempts by man to justify and sanctify himself before a willfully and arbitrarily devised image of God" (I.2, 280/304, 33). Barth's definition of culture (Kultur) is not explicit and must be inferred from scattered mentions. ${ }^{15}$ It seems, as Jessica DeCou aptly

\footnotetext{
${ }^{15}$ In his 1926 address, "Church and Culture," Barth offers a theological definition : "Culture is the task set through the Word of God for achieving the destined condition of man in unity of soul and body." See Karl Barth, Theology and Church: Shorter Writings 1920-1928 (London: SCM Press, 1962), 337. He offers a more succinct definition on the next page: "Culture means humanity" (Barth, Theology and Church, 338). Most commonly appeals are made to Barth's discussions of culture in IV.3, $\$ 69.2$ and Mozart essays, see Karl Barth, Wolfgang Amadeus Mozart (Grand Rapids: Eerdmans, 1986). However, I agree with Jessica DeCou, and against Paul Metzger and Robert J. Palma, when she claims that "Though Barth expressed a
} 
puts it, that Barth had an "allergy to [a] 'theology of culture' [that] was influenced by his aversion to modern theological trends toward the deification of human achievements that, in his view, led theology to be uncritical of (and eventually absorbed by) the larger culture." I6 read Barth with Kathryn Tanner's Theories of Culture in mind. Tanner views culture as a

consensus-building feature of group living...[that] forms the basis for conflict as much as it forms the basis for shared beliefs and sentiments. Whether or not culture is a common focus of agreement, culture binds people together as a common focus for engagement...Participants are bound together by a common attachment to or investment in such cultural items, and not necessarily by any common understanding of what they mean. ${ }^{17}$

Therefore, for Tanner, as for Barth, ${ }^{18}$ "Theology is something that human beings produce... as a part of culture, as a form of cultural activity." ${ }^{19}$ Such a definition allows Barth to separate revelation (as outside of culture) from religion (a product of culture) while allowing cultural forms to serve as the media of God's self-revelation. With these definitions in hand, we turn to the task of interpreting Barth's views on revelation, religion, and culture and their inter-relations.

In $\S 69$, Barth presents "one of the most original (and least studied) tracts in the 
entire Church Dogmatics, ${ }^{20}$ in the words of John Webster. The part-volume proceeds in four subsections:

$\S 69.1$ : The Third Problem of the Doctrine of Reconciliation

§69.2: The Light of Life

$\S 69.3$ : Jesus is Victor

$\S 69.4$ : The Promise of the Spirit

In volume IV of his Church Dogmatics, Barth uses the threefold office of Jesus Christ, the munus triplex, to organize his Doctrine of Reconciliation. ${ }^{21}$ The first three partvolumes present expositions of Christ as priest (IV.1), Christ as king (IV.2), and Christ as prophet (IV.3). ${ }^{22}$ In IV.1, Barth employs the motif of humiliation, "The Lord as Servant: Jesus Christ, Son of God" (§59) and in IV.2, the motif of exaltation, "The Servant as Lord: Jesus Christ, Son of Man” (§64). In IV.3, Barth proceeds to "think together" (zugleich denken, I.2, 160/175) the person of Christ as - human and divine-with the work of Christ — in justification and sanctification — as the God-man, "The True Witness:

\footnotetext{
${ }^{20}$ John Webster, Barth $2^{\text {nd }}$ edition (New York: Continuum, 2004), 131.

${ }^{21}$ For more on Barth's use of the munus triplex in English, see: Bruce L. McCormack, "Karl Barth's Historicized Christology: Just How 'Chalcedonian' is it?", in Orthodox and Modern: Studies in the Theology of Karl Barth (Grand Rapids, MI: Baker Academic, 2008), 202; Paul Dafydd Jones, The Humanity of Christ: Christology in Karl Barth's Church Dogmatics (New York: T\&T Clark, 2008), 122126; George Hunsinger, Disruptive Grace: Studies in the Theology of Karl Barth (Grand Rapids: Eerdmans, 2000), 141-2, n. 18; Adam Neder, Participation in Christ: An Entry Into Karl Barth's Church Dogmatics (Louisville: WJK, 2009), 74-5; Karin Bornkamm, "Die reformatorische Lehre vom Amt Christi und ihre Umformung durch Karl Barth" in Zeitschrift für Theologie und Kirche ed. Eberhard Jüngel (Tübingen: Mohr Siebeck, 1986), 3-32; Karin Bornkamm, Christus-König und Priester: Das Amt Christi bei Luther im Verhältnis zur Vor- und Nachgeschichte (Tübingen: Mohr Siebeck, 1998), 382-385; Hans Urs von Balthasar, The Theology of Karl Barth: Exposition and Interpretation, tr. Edward T. Oakes (San Francisco: Ignatius, 1992), 391-2; Colin E. Gunton, The Barth Lectures, ed. Paul Brazier (New York: T\&T Clark, 2007), 201; Anna Maria Schwemer, "Jesus Christus als Prophet, König und Priester. Das munus triplex und die frühe Christologie;" in Der messianische Anspruch Jesu und die Anfange der Christologie, eds. Martin Hengel and Anna Maria Schwemer (Tübingen: Mohr Siebeck, 2001), 165-230; and Jürgen Moltmann, "Trends in Eschatology" in The future of creation: collected essays (Minneapolis: Fortress, 1979), 23-27. Also see Barth's alleged superficial misuse of the doctrine in Adam J. Johnson, "The Servant Lord: A Word of Caution Regarding the munus triplex in Karl Barth's Theology and the Church today" Scottish Journal of Theology 65:2 (2012): 159-173.

${ }^{22}$ The fourth part-volume containing Barth's ethics of reconciliation was never finished, portions of its first half were published as IV.4, §75-The Fragment on Baptism and then $\S \S 74,76,77$, and 78 as unedited drafts in Karl Barth, The Christian Life: Church Dogmatics IV.4, Lecture Fragments (ed. Hans-Anton Drewes and Eberhard Jüngel; trans. Geoffrey Bromiley; London: T\&T Clark, 2004). Cited hereafter as TCL with page number for the English translation/the German original.
} 
Jesus Christ, the Mediator.” In the pattern of IV.1 and IV.2, Barth again follows the Christological exposition with a discussion of sin: as falsehood opposed to the true witness of the prophet (§70). In turn, $\S 71$ considers the impact of Christ's prophetic activity on the human being. Whereas Christ's humiliation led to human justification in IV.1, §61, and Christ's exaltation led to human sanctification in IV.2, §66, the unity of the God-man and the proclamation of Jesus' life led to human calling or vocation in IV.3, $\S 71$. In the final sections on the Holy Spirit $(\S \S 72,73)$, the sending of the Son by the Father in the incarnation is applied to the Christian community that exists for the world (§72) and that had previously experienced gathering (IV.1, §62) and upbuilding (IV.2, §67). To conclude his threefold exposition of the office of Jesus Christ in his doctrine of reconciliation, Barth meditates upon the Holy Spirit and Christian hope (§73) following faith $(\S 63)$ and love $(\S 68){ }^{23}$

In IV.3, the double-movement, downwards and upwards, of Christ's humiliation and exaltation, in his life, death, resurrection, and ascension, now are proclaimed in the outward movement of Christ as prophet. The description of the acts of Christ described in IV.1 and IV.2 remain incomplete without the account of proclamation in IV.3. In late 1955, just after completing work on IV.2, Barth responded to an informal student question about the significance of his architectural arrangement of the Church Dogmatics with regard to Calvin's ordering (prophet, king, priest) and Schleiermacher's (prophet, priest, king), Barth replied:

Now you want to know why I use the order: priest, king, prophet. For me the priestly and kingly offices in the narrower sense are the doings of Christ. The humiliation of God in becoming man and the exaltation of man up to God are respectively Christ's priestly and Christ's kingly work.

\footnotetext{
${ }^{23}$ For helpful pictorial representations of the paragraphs in volume four, see Jüngel, Karl Barth, 48-49, and Jones, Humanity of Christ, 266.
} 
Christ the Prophet is Christ revealing Himself as King and Priest. To make clear what happens when He reveals Himself, I have to know what $\mathrm{He}$ is and does. I distinguish between reality and truth. The truth is the truth of this reality. To speak the truth I have to begin with this reality. Christ's priestly and kingly offices are the subject-matter, the content of His prophetic office, because He reveals Himself. Hence I use this order. ${ }^{24}$

The priestly and kingly offices must be treated first because they are the material content of proclamation of the third, prophetic office. If theology communicates truth about God, then the truth of the reconciliation of humanity in Jesus Christ is proclaimed in Christ's ongoing prophetic activity.

\section{I.B.}

\section{Prophecy, History, and Narrative}

In Barth's response to the student's question, he states that in order to proclaim Christ prophetically one must first know who Christ is and what Christ does (has done, is doing and will do). ${ }^{25}$ In seeking to know who Jesus Christ is and what he does, Barth roots his understanding of revelation in God's concrete actions in the world. The work of the prophet is to proclaim what the priest and the king have accomplished. Barth always views God in Jesus Christ as a single subject, the unified God-man. There are not separate parts of Christ that perform these different roles. As such, the threefold office is one office of Jesus Christ that is described in three ways. The priestly and kingly work demonstrated that reconciliation for all humanity had been accomplished in Christ's atonement. In the opening words of the Christological paragraph in IV.1, Barth describes his understanding of the atonement and its connection to history. Barth writes,

\footnotetext{
${ }^{24}$ From Question and Answer period after John Godsey's paper on "The Architecture of Karl Barth's Church Dogmatics," Karl Barth's Table Talk, recorded and ed. John Godsey (Richmond, VA: John Knox Press, 1963), 17.

${ }^{25}$ Godsey, 17.
} 
The atonement is history (Geschichte). Whoever wants to know it, must know it as such. Whoever wants to think of it, must think of it as such. Whoever wants to speak of it, must recount it as history. Whoever wants to try to grasp it as supra-historical - which is to say, ahistorical truth - is quite unable to grasp it. It is indeed truth, but truth that happens in a history and in this history as such is revealed...The atonement is the most particular history of God with humanity, the most particular history of humanity with God (IV.1, 157 rev./171).

Atonement is history, is achieved in human history, in the history of the God-man, and cannot be known apart from that history. Importantly, Barth uses the German word Geschichte, to describe the type of history that best describes the atonement.

Geschichte has a broad meaning. ${ }^{26}$ In addition to "history"- as a "a cluster of events in time and space, potentially susceptible to narration," Geschichte can also be translated as "story"-_a retelling of events that draws attention to their coherence and meaning." ${ }^{27}$ This meaning of "story" is not a fictional composition, but captures the understanding of history as a narrative. Paul Dafydd Jones helpfully summarizes the significance of the usage of Geschichte in Barth: "whatever the elasticity and myriad connotations of Geschichte, it indicates that Christ's divine-humanity undertakes, and has no meaning in isolation from, the reconciling life witnessed in scripture. ${ }^{28}$ Barth’s understanding of atonement as history is rooted in the actual events of Jesus Christ's life, death, resurrection, and ascension as recorded in the Bible.

${ }^{26}$ In The Humanity of Christ, Jones identifies four closely related meanings of Geschichte in Barth's Dogmatics:

1. "God's pre-temporal elective intention [as it relates to Christ, is]...Basic to God's life, in a decision coordinate with God's self-assigned identity as three relating Seinsweise [modes of being]- God intends to create, sustain, and relate companionably to humankind" (189).

2. "a pair of closely related claims: (a) the life of Jesus Christ constitutes the identity of Jesus Christ, which, in turn, (b) God makes constitutive of the identity of God qua Son" (191).

3. "Christ's life as a reconciliatory event that mediates the relationship between God and humanity" (195).

4. "Christ's reconciling life-unto-death as the way of covenant fulfillment" (199).

${ }^{27}$ Jones, The Humanity of Christ, 200.

${ }^{28}$ Jones, The Humanity of Christ, 191. 
The history of Jesus Christ as the history of reconciliation means, further, that Jesus Christ is the saving fulfillment of the covenant. Barth plays with this meaning of Geschichte throughout $\S 69$. He claims that it is in and through the history of Jesus Christ that humans know God: "Whoever says Jesus necessarily says: history (Geschichte)-his history-the history in which he is who he is and does what he does. In his history, we know God" (IV.3, 179 rev./205). God reveals who God is (God is what God does), and humanity knows God through God's reconciling actions towards humanity. This is what Barth means by "Reconciliation is revelation." Reconciliation is history (IV.3, 181/207) and the history of reconciliation is revelation. There is no private sphere, nowhere that Christ's prophetic activity is not known or felt, even if there are many places where it is not recognized as such (IV.3, 182/208). The office of Christ as prophet is to proclaim the reconciliation that has been accomplished through Christ's priestly and kingly work.

Although the event of reconciliation is complete (and in one sense "finished"), it also continues. In Barth's words, Christ's “history has been, but it has not passed...As history, it begins with history. But although this history of Jesus Christ took place once, in its very singularity it really takes place, and therefore shines and speaks, for all times and in many other times" (IV/3, 224/256). For sure, the history of Jesus Christ is bound to the gospel narratives. Yet, because the event of reconciliation includes Christ's resurrection from the dead, Jesus Christ continues to act today. While his time on earth in human flesh has passed, he and his Geschichte (history/story) live on. ${ }^{29}$ Through the power of the resurrection, specifically, Jesus Christ keeps on acting, not as a principle, but as a person who bears his past and present into the future. The living Jesus Christ "is

\footnotetext{
${ }^{29}$ For Barth, "He, Jesus Christ, lives...His existence is act; that it is being in spontaneous actualization" (IV.3, 39/41, 40/42).
} 
not something but Someone who lives...[not] He has lived or...He will live" (IV.3, 40/42, 44/47).

With characteristic objectivism, Barth declares, "that the life of Jesus Christ speaks for itself"' (IV.3, 45/49). In this self-speaking, Christ is

His own authentic witness...[and] the light of life...the light which life itself radiates because it is itself light. As Jesus Christ lives, He also shines out, not with an alien light which falls upon Him from without and illuminates Him, but with His own light proceeding from Himself (IV.3, 46/49).

The sum and substance of this prophetic message is a recollection of the tetragrammaton and a summary of the fourth gospel: "I am" (IV.3, 181/207); Barth's emphasis on Jesus Christ as a living person defines the content of $\S 69$.

The glory of the mediator is then who Christ is, what Christ has done, and Christ's ongoing prophetic activity. He is revealed by and as he reveals himself as the one he is, in what he does-his being is in his action (IV.3, 275/317). Barth has "conjoined" the person of Christ with the office of prophet in order to show that God is revealed in Christ, as the light of life (§69.2) and that Christ reveals himself, shining as the Light (§69.3). §69.4 transitions to the remaining paragraphs of IV.3 as the focus turns from the purely Christological to the outworking of these Christological claims about the ongoing prophetic activity of Jesus Christ to the realms of sin, soteriology, pneumatology, and ecclesiology. Barth continually reinforces that Christ's offices are inseparable from one another and notes repeatedly that the high-priestly and kingly offices require the third (the prophetic) to describe "the outreaching, embracing, and comprehensive character" of the atonement (IV.3, 279/321). Indeed, one can even say that the priestly and the kingly 
require the prophetic, just as the salvific power of Christ's life and death requires the resurrection. He writes,

His high-priestly and kingly work, and therefore the justification and sanctification of man as they have already taken place in His life and death. In His new coming, in His arising from the hosts of the dead, it took place that the alteration of the situation between God and man accomplished by Him was actualised by taking place immediately and completely in noetic form also as the prophecy of Jesus Christ (IV.3, 296297/342).

The ongoing movement of prophetic activity that took place even in Christ's ascension to the living God continues toward all humanity and the world (IV.3, 356/411).

The resurrection as prophetic proclamation receives particularly close attention, for this is the medium in which Christ reveals himself in the present and future. Because of the resurrection, reconciliation can be communicated in diverse ways. "Without this event," Barth writes, "it would have lacked the glory and revelation and therefore the prophetic character of His being and action. His life would still have been the life of the whole world, but it would not have been light shining in this world and illuminating it" (IV.3, 282/326). The resurrection announces to the world that Jesus Christ is no ordinary human being; death could not contain him. The prophetic proclamation of Christ's identity in the resurrection does not only declare humanity's reconciliation with God; the resurrection publishes the fact of reconciliation, and in so doing applies reconciliation to individuals and communities. "Without this event beyond His life and death which destroys His death," Barth writes, "He could not be the One who comes to us as He who has lived and died for us, but only the One who in His death has gone infinitely far from us like anyone else who dies" (IV.3, 283/326). 
In response to the impact of the resurrection on Christ's ongoing prophetic activity, Barth called the third sub-section of §69: “Jesus is Victor" (IV.3, 165-274/188317). As noted earlier, Barth took this title from an encounter that the German Pietist Lutheran pastor, J.C. Blumhardt had with a young woman, Gottliebin Dittus, who claimed that she was possessed by a demon in 1843 . As Blumhardt was working to cast out the demon, he heard Dittus cry out, "Jesus is victor!" in the moments just prior to the demon leaving her (IV.3, 168-171/192-196). Barth was quite struck by this story and chose the phrase as the title of this sub-section,

for the simple reason that this statement, which is really to be heard and read as a challenge, is the sign under which a presentation and therefore a narration (Erzählung) of the prophetic work of Jesus Christ must always stand. It tells of the issue but also of the beginning of the action, and in so doing of the dynamic and teleological character which marks it from its commencement to its goal. "Jesus is Victor," is the first and last and decisive word to be said in this respect (IV.3, 168/192).

The resurrection is a narrative historical event for Barth. The resurrection happened in space and time, but it also re-wrote the very human history (story) of Dittus; it intervened, reframing this woman's life. The power of God shown forth in the resurrection, on this reckoning, is not confined to the past, but remains active in the world even today. This very power - the power of the resurrectionset Dittus free from demon possession.

The poignancy of Barth's choice of title clearly comes through in the excursus where he responds to C.G. Berkouwer's characterization of his theological progress as the triumph of grace..$^{30}$ Berkouwer sought to find a single, unifying principle within Barth's work and articulated it as grace overcoming all. The thrust of Barth's strong reply 
was that "Jesus is Victor" is a better characterization than "The Triumph of Grace," because he is not concerned with the "principle" of Grace, but instead with the living person of Jesus Christ (IV.3, 173/198).

In sum, the resurrection certainly expresses this grace and the phrase, "Jesus is Victor!," describes the accomplishment of the reconciliation of all humanity (IV.3, 191/218). Through the ongoing prophetic activity of Jesus Christ, "the light of life shines in the darkness, the world and all men come within the reach of its beams, but as it shines in the darkness, the world and all men are still in the sphere of darkness" (IV.3, 191/218). This light penetrates the darkness, but does not eliminate the darkness. "That reconciliation is also revelation means that in its accomplishment, which establishes, orders and guarantees peace between God and man, it also reveals and proclaims itself as divine-human truth" (IV.3, 165/189).

\section{II. Revelation}

The self-revelation of Jesus Christ occurs in and through the reconciliation of humanity to God. Barth bases his understanding of revelation in $\S 69$ upon the ongoing prophetic activity of Jesus Christ. This ongoing activity is made possible through Christ's resurrection, as the risen Christ raises up witnesses to himself. Barth's explication of revelation in $\S 69$ has three distinctive elements.

A. All revelation is self-revelation; there is no possibility of revelation apart from God's self-revelation. Specifically, Jesus Christ, and Jesus Christ alone, is the full

\footnotetext{
${ }^{30}$ See C.G Berkouwer, The Triumph of Grace in the Theology of Karl Barth (London: Paternoster Press, 1956), previously published in Dutch (1954), and in German (1957). Barth offered a preliminary response to Berkouwer's book in the preface to IV.2 and a more extended engagement in IV.3, 173-180/198-206.
} 
revelation of God as Son. Jesus Christ fully reveals who God, the Son, in relation to the Father and the Son, is; there is no "God" hiding behind the God who is revealed in Christ. Through the reconciling acts of Christ's life, death, resurrection, and ascension, the character of God is revealed to humanity.

B. Revelation is not just for Christians or the Christian community, but also for all people at all times and places. Revelation is also universal in as much as it coincides with the universal reconciliation of all humanity to God in Jesus Christ. Again, the content of revelation is the person of Jesus Christ, not any principles or concepts derived from the bible or elsewhere.

C. Revelation is ongoing in and through the prophetic activity of Jesus Christ. Through the work of Christ and the Holy Spirit, God continues to reveal who God is in new times and places. Although who God is does not change, the mediums of communications do change from one social-historical context to another and human interpretations of God's revelation result in different understandings of who God is.

Barth's account of revelation as the self-revelation of God in Jesus Christ, decenters "religion" from a position of power and authority as the controller of information or of access to the divine. Indeed, as God reveals who God is in unexpected places, the Christian community is called to live in correspondence to God's prophetic revelation and live in humble service to others.

\section{II.A.}

\section{All Revelation is Self-Revelation: Imagery of Light}

For Barth, revelation is the 'how' of the 'what' of reconciliation; revelation makes clear and proclaims the work of Jesus Christ. Barth understands "that, as reconciliation 
takes place, it also declares itself" (IV.3, 10/8-9). Indeed, revelation "takes place as reconciliation takes place; as it has its origin, content and subject; as reconciliation is revealed and reveals itself in it" (IV.3, 9/7). Thus, revelation is coextensive with the ongoing prophetic activity of Jesus Christ.

Just as the life of the Son of God has been engaged in the event of reconciliation from the beginning of time, revelation has been the proclamation of reconciliation since the beginning. Barth appeals to the prologue of the gospel of John to defend his claim. John 1:1 reads, "In the beginning was the Word (Logos) and the Word was with God and the Word was God." Barth uses this verse to place Jesus Christ (the Logos) at the beginning as one with God. In his exegesis of John 1:4, Barth yokes together revelation and reconciliation: "In him was life; and the life was the light of all men. And the light shineth in darkness" (IV.3, 9/7). By connecting Jesus Christ with life and light, in contrast to darkness, John 1:4 serves as the theme verse for Barth's exposition in $§ 69$.

The event of reconciliation in Jesus Christ "is outgoing and self-communicative, announcing, displaying and glorifying itself. It is not merely light but the source of light" (IV.3, 10/9). ${ }^{31}$ In contrast to the Christological paragraphs in IV.1 and IV.2 that focused on the downward movement of Jesus Christ toward humanity (\$59) and the upward movement of Jesus Christ with humanity toward God (§64), here in $\S 69$, Barth now emphasizes the outward movement of reconciliation. By connecting the imagery of glory to light, as will be explored in more depth below, Barth insists that reconciliation is not simply a past event, but a continued source of light that shines and announces God's work in Jesus Christ.

${ }^{31}$ The imagery of glory introduced here is closely tied to light for Barth as will be explored below. 
Barth is re-affirming his Christocentric approach to theology here, much as he has practiced throughout his Dogmatics. His method is to speak first of God in Christ, then of humanity as such, then of human knowledge of Jesus Christ. Therefore the person and work of Christ are the primary (and inseparable) means by which humanity comes to know who God is (and who they are) through the acts of Jesus Christ as recorded in the biblical witness. Specifically, Barth uses the office of Prophet where, as in the Old Testament, the message and the messenger were inextricably intertwined. Jonah's reluctance to go to Nineveh to call for repentance landed him inside a whale. Hosea was instructed to marry a prostitute as an example of Israel's unfaithfulness. Jesus as the true Prophet, the fulfillment of the type, proclaims the message of the kingdom of God with his very body in his actions. Jesus' life, death, resurrection, and ascension proclaim to all the reconciliation between humanity and God. For Barth then, "Reconciliation is indeed revelation. But revelation in itself and as such, if we can conceive of such a thing, could not be reconciliation" (IV.3, 8/7). If there were words that could be uttered, true words even, that reveal who God is, these words would not, in and of themselves, bring reconciliation of humankind. Yet, the acts of Jesus Christ not only perform the reconciliation of humanity to God, but they proclaim it as well. In this way, Barth understands "[t]hat reconciliation is also revelation is first and decisively event and reality in Him who is its Mediator and Accomplisher in His own person" (IV.3, 38/40). The person of Christ and the work of Christ are held together in Barth's understanding of the ongoing prophetic activity of Jesus Christ. Revelation is for Barth the act of reconciliation as it confronts human beings. 
Barth's understanding of how revelation occurs is consistent with his memorable articulation of God's sovereignty in the opening part-volume of his Church Dogmatics:

If the question what God can do forces theology to be humble, the question what is commanded of us forces it to concrete obedience. God may speak to us through Russian Communism, a flute concerto, a blossoming shrub, or a dead dog. We do well to listen to Him if He really does (I.1, 55/56).

The point in I.1 is repeated in $§ 69.2$ : God's self-revelation can, in principle, take any form. God's sovereignty is such that God has the power to speak through anything at all. Most importantly, God is the one who speaks; humanity's role is to listen. Yet, in $\S 69$, Barth fills in the content of revelation more fully than in I.1. The content of God's selfrevelation is always Jesus Christ. Barth hints in this direction when he writes, "The equation of God's Word and God's Son makes it radically impossible to say anything doctrinaire in understanding the Word of God... The only system in Holy Scripture and proclamation is revelation, i.e., Jesus Christ. Now the converse is also true, of course, namely that God's Son is God's Word"' (I.1, 137/142). For sure, late in I.1, Barth begins to make the argumentative moves that he will develop in $\S 69$. There are anticipations, in I.1, of Barth's moves in $\S 69$, but they are only anticipations. In I.1, §11, he writes, "If they are to be authentic revelations and reconciliations, they can only be identical with the revelation and reconciliation through the Son of God. Jesus Christ will have to be recognised as living and acting in them. The one revelation and reconciliation will not be one among others" (I.1, 425/446). ${ }^{32}$ Yet, while maintaining the singular uniqueness of

\footnotetext{
${ }^{32}$ In a somewhat perplexing passage in $\S 11$, Barth claims that "revelation is itself reconciliation," a position which, as noted above, he retracts in $\S 69$. See: "The fact that God can first tell us anything, this primary inconceivability in view of His wrath on sinful man, is in God's revelation the work of the Son or Word of God. The work of the Son or Word is the presence and declaration of God which, in view of the fact that it takes place miraculously in and in spite of human darkness, we can only describe as revelation. The term reconciliation is another word for the same thing. To the extent that God's revelation as such accomplishes what only God can accomplish, namely, restoration of the fellowship of man with God which we had
} 
reconciliation in Jesus Christ, at this point, Barth only anticipates what will come later in describing how Christ will be recognized and how revelation and reconciliation are related. More forcefully than before, Barth defines in $\S 69$, the "matter of reconciliation as revelation" (IV.3, 38/40). ${ }^{33}$

In his second part-volume on the Word of God, Barth did discuss prophecy in the Old Testament (I.2, 84/92) $)^{34}$ and the threefold office of prophet, priest, and king (I.2, 254/277). Again, there are hints in I.2 demonstrating a continuity of thought with $\S 69$, though the earlier presentation lacks the fullness of the later exposition. ${ }^{35}$ The focus on Jesus Christ as the subject of revelation initiates an examination of the Incarnation. Both the necessity of God taking human form and the distinctiveness of Jesus Christ's incarnation are of interest to Barth. He writes,

He would not be revelation if He were not man...[I]t is here that we find ourselves at the point at which the biblical doctrine of the incarnation of the Word and the familiar parallels in the history of religions part company. There are also incarnations of Isis and Osiris; there is an incarnation in Buddha and in Zoroaster. But it is only the New Testament that says "he hath made him to be sin" and "he became a curse for us." Only here do we have so strict a concept of Emmanuel, of revelation and reconciliation (I.2, 152/167).

\footnotetext{
disrupted and indeed destroyed; to the extent that God in the fact of His revelation treats His enemies as His friends; to the extent that in the fact of revelation God's enemies already are actually His friends, revelation is itself reconciliation. Conversely reconciliation, the restoration of that fellowship, the mercy of God in wrath triumphant over wrath, can only have the form of the mystery which we describe as revelation" (I.1, 409/429-430, underlining added).

${ }^{33}$ Significantly, the prophetic actualism and activity of Christ articulated in $\$ 69$ follow Barth's insight in II.2 about Christ as the Elect One. While not necessarily required, the placing of election within the doctrine of God in II.2 surely adds clarity to who God as Son is, that is then explored in IV.3.

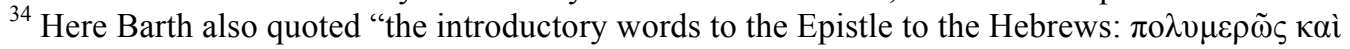

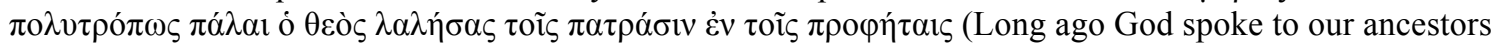
in many and various ways by the prophets)" (I/2, 84/92).

${ }^{35}$ See also: "Revelation remains revelation and does not become a revealed state. Revelation remains identical with Christ and Christ remains the object of Christian faith, even though He lives in Christians and they in Him" (I.2, 118/131).
} 
The revelation of God in Jesus Christ does not merely take human form, but human flesh-fallen, sinful flesh. ${ }^{36}$ Christ assumed human flesh in order to redeem humanity from the curse of sin. That God-in-the-flesh takes on the polluting and defiling sin of humankind differentiates Jesus Christ from the central figures in world religions.

Barth uses the prologue of John's gospel for his Christology here in I.2, to propose that the way to understand the Incarnation is to "think together [zugleich

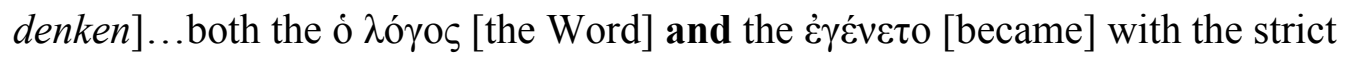
simultaneity with which they are given us in Scripture" (I.2, 160/175; John 1:14). This "strict simultaneity" that Barth proposes here in the Christological paragraph in I.2, §15, serves as the inspiration for $\S 69$, as the divine nature of Christ (most directly articulated in IV.1, §59) and the human nature of Christ (most directly articulated in IV.2, §64) are "thought together" in the ongoing prophetic activity of Jesus Christ as mediator and revealer in IV.3, $\$ 69 .{ }^{37}$

As Barth filled-in his understanding of revelation between I.1 and IV.3, he appropriated the imagery of light to describe God's self-communication. ${ }^{38}$ By II.2, Barth had moved closer to the position he will assert in $\S 69$, including adopting the imagery of light:

\footnotetext{
${ }^{36}$ Here we can recall Gregory of Nazianzus' fourth-century dictum (also in Athanasius): "the unassumed is the unhealed." Gregory Nazienzen, Letter 101, "To Cledonius the Priest against Apollinarius," in Philip Schaff and Henry Wace, eds., The Nicene and Post-Nicene Fathers, Second Series, vol. 7 (New York: C. Scribner's sons, 1903), 839. Bediako twice cites this quotation, see Bediako, Religion, Culture and Language, 36, and Bediako, "Thoughts on the nature of the project" JACT 11.2 (2008): 3.

${ }^{37}$ In a distinct, though not entirely unrelated vein, for more of Barth's use of simultaneities in the doctrines of justification and sanctification, see George Hunsinger, "A Tale of Two Simultaneities: Justification and Sanctification in Calvin, Luther and Barth," in Conversing with Barth, eds. Mike Higton and John C. McDowell (Burlington, VT: Ashgate, 2004), 68-89.

${ }^{38}$ For scholarly discussions of Barth's understanding and use of "light" (Licht) see: Hendrik Berkhof and H.J. Kraus, Karl Barths Lichtlehre (Zurich: Theologischer Verlag, 1977); Henry Mottu, "La Lumière et les Lumières. Christ et le monde selon le dernier Barth, 1988" in Un Itinéraire Théologique: Barth, Bonhoeffer et la Théologie Africaine-Américane (Genève: Cahiers de la Revue de Théologie et de Philosophie 21,
} 
Jesus was the life which was light, the revelation of God, the saying, or address, or communication in which God declares Himself to us. But as this revelation He was not something other outside and alongside God. He was God Himself within the revelation. He was not revelation alone, then, but in the revelation He was the principle, the intrinsically divine basis of revelation. He was revelation in its complete and absolute form (II.2, 97/104, emphasis added).

Here Barth directly equates the life of Jesus with the revelation of God in a more blunt way than in I.2. God has chosen to address humanity in and through the life of Jesus Christ. The life of Jesus is "revelation in its complete and absolute form" (II.2, 97/104). By looking at the life of Jesus Christ, humanity can come to know God. The life of Jesus is light. This light publicizes and proclaims the already accomplished work of Christ in justification and sanctification. The life shines and that shining is light. There is not another light separate from the life of Jesus Christ. The light shines freely on all peoples, displaying the work of Christ on their behalf. The use of the imagery of light dominates $\S 69$, most notably in the title of $\S 69.2$ : "The Light of Life."

Yet the use of light to describe the life of Jesus Christ is not new in IV.3. In $§ 69$, Barth ties Jesus Christ as the "Word of life" in 1 John 1:1 and the "light of life" to the Biblical concept of glory ( $k a b o d / \delta o ́ \xi \alpha / g l o r i a)$ and to his earlier discussion of "glory" in II.1 (IV.3, 47/51). In his presentation on "The Perfections of God," in II.1, Barth discussed "The Eternity and Glory of God" in $§ 31.3$ (II.1, 640-677/722-764). Barth wrote that:

Kabod [the Hebrew word for glory in the Old Testament] is light, both as source and radiance. In this sense kabod is ascribed to Yahweh, and Yahweh's being and presence and activity are described in terms of various natural forms of light, the lightning or the sun or fire, and are recognised in these natural phenomena. The glory or honour of God is the worth which God Himself creates for Himself (in contrast to what He is

2004), 36-48; and Karl-Friedrich Wiggermann, “'Ein eigentümlich beschatter Bereich': Die Neuzeit in Karl Barths 'Lichterlehre,"' Zeitschrift für Dialektische Theologie 25:2 (2009): 119-138. 
not) simply by revealing Himself, just as light needs only itself and has only to be light in the midst of darkness to be bright and to spread brightness in contrast to all the darkness of heaven and earth. It is in this way that God is glorious. It is in this way that glory belongs to Him, and in a literal and true sense to Him alone. Only God is light in this sense. All other light and also all other glory (especially all the glory of men) can only copy Him. Thus the New Testament is simply repeating the fulfilled testimony of the Old when in its decisive strand it describes the glory of God as the glory of Jesus Christ (II.1, 642/724).

Christ in his full divinity shines and reveals who God is. In fact, Barth foreshadows the outshining of the Light of Life (in §69.2) here in II.1. The glory of God is self-revealing, it displays who God is with out effort or decision. Since the glory of God "is the selfrevealing sum of all divine perfections" (II.1, 643/725), its revelatory acts are perfect and complete. God is a being "which declares itself” (II.1, 643/725). §69, Barth specifically names the glory of God. Jesus is "the authentic image of the glory of God...His doxa, His power of revelation is a concrete event" (IV.3, 48/51). The concrete actions of the actual human being Jesus Christ reveal who God is.

In distinction from all the prophets of the Old Testament, Jesus Christ's "prophecy is universal prophecy" (IV.3, 50/53). His prophecy is not for Israel alone, but it is light shining on and for the whole world. Christ's prophecy is unique (IV.3, 4952/52-57), yet it is consistent with the prophetic history of Israel (IV.3, 53-65/ 57-70). ${ }^{39}$ Barth writes, "the history of Israel says earlier what that of Jesus Christ says later" (IV.3, 66/71). There is only one prophet, one revelation, one light, and one word, one "biblical and Christian theology" (IV.3, 71/78). There is only one Prophet of one

\footnotetext{
${ }^{39}$ See also: "Yet the fact that the history of Israel can have no more continuations does not mean that it is outmoded, replaced or dissolved. It cannot be outmoded, because already the one covenant between God and man, instituted in the eternal election of Jesus Christ, was its basis, content and goal; because it was already actualised in it in this first form as national history; and because Jesus Christ already spoke and acted in it as His type, His pre-history and fore-word" (IV.3, 70/76).
} 
covenant who was first concealed (in Israel), then revealed (in Jesus Christ). The selfrevelation occurs through the life of Jesus Christ, the Light of Life. This revealing light shines on all people; revelation is no longer restricted to one people.

Ivor Davidson articulates this connection between the doctrine of God and divine luminosity as follows:

The triune God really does shine forth, dispelling creaturely darkness by the sheer potency of his inner splendor, reaching us as he really is. The distinction between that outshining towards creatures and God's inner glory is best elaborated not by a distinction between essence and energies, far less between uncreated and created light, but by speaking of the freedom of God's will to make visible for creatures something of what is eternally visible to God himself. ${ }^{40}$

In God's eternal freedom, God chooses to shine light into the world. The outshining of the light expresses who God is in God's innermost being. The light shines because of "the freedom of God's will" in choosing to make things visible. God freely shines the light of life upon all people because God's eternal decision has been to be in relationship with humanity. God freely gives the light but in giving himself, God does not give himself away. The concept of light does not encapsulate the being of God. Instead, God is light. Light is not something apart from the being of God. There is no other God than the one who shines out, no light-force behind the triune God. As the light shines, it calls forth a response from those it reaches. Even in the shining of the light, God remains sovereign.

From Davidson's perspective, Barth's discussion of light is quite unusual among twentieth and twenty-first century theologians. "A fair bit of theology," he writes, "modern and postmodern, might be said to have proceeded pretty much as if God were

\footnotetext{
${ }^{40}$ Ivor Davidson, "Divine Light: Some Reflections after Barth," in Trinitarian Theology after Barth, eds. Myk Habets and Phillip Tolliday (Eugene, OR: Princeton Theological Monograph Series/Pickwick Publications, 2011), 65.
} 
not light at all...[On the contrary,] Barth's dogmatics offers a sustained endeavor to grapple with what it is to confess that the God who is all-glorious in himself invades and dispels our darkness. ${ }^{41}$ Davidson has put his finger on the distinctive outward movement of the ongoing prophetic activity of Jesus Christ. For Barth, God is not withdrawn or isolated from humanity. Neither is God simply a projection of human yearnings in the way that Barth critiqued Kulturprotestantismus (European Protestant culture). Instead, God is living, active, and as evidenced in the incarnation, "on the loose" among humanity. God is not content to leave humanity to our own devices. The light of God publicizes and proclaims the reconciling work of the life of Jesus Christ.

There are other lights, what Barth refers to as lesser lights, but these other lights only shine because of the light of Jesus Christ (IV.3, 97/107). The life of the living GodMan Jesus Christ is self-disclosing and self-revealing in ways that all can hear (eloquent) and see (radiant). "Because it is the life of grace," Barth writes, "it is this eloquent and radiant life (sprechendes, leuchtendes Leben)" (IV.3, 81/90). There are also "true words" that may be spoken outside the walls of the Church; they too communicate the one Word of God, Jesus Christ (IV.3, 110/122). The life of Jesus Christ as the Light of Life bears witness to the being of God through its ongoing prophetic activity that revealed who God is in the life, death, resurrection, and ascension of Jesus Christ and continues to bear witness through the shining of true light and the proclamation of true words to all people.

\section{II.B.}

\section{Revelation is for all people: History/Worldview}

For Barth, as one not interested in theological theories or abstractions in and of

\footnotetext{
${ }^{41}$ Davidson, 67, 68.
} 
themselves, the key to every theological locus is the person of Jesus Christ. Thus, in terms of revelation, in his prophetic office, Jesus Christ, is the sole and sufficient revelation of God. In the opening of volume IV of his Dogmatics, Barth wrote that Jesus Christ,

Himself is the "epistemological principle." But we must be careful not to understand Him only in this way, for, if we do, the Christian message will at once degenerate into the self-declaration of an ecclesiastical form of redemption instituted indeed by Him but now self-resting and selfmotivated, or into a devotional and ethical system taught indeed by Him but self-justified and self-sufficient, or into an illumination of existence strikingly fulfilled by Him in history but living by its own light (IV.1, 21/21).

Barth names this self-justified and self-sufficient system, "a myth" (IV.1, 21/21). The only place to look for true knowledge of God is in the person of Jesus Christ. (Here, Barth is criticizing Roman Catholicism, certain aspects of pietism, and German Kulturprotestantismus). Theories about Jesus Christ are not sufficient. Only Jesus Christ himself fully and sufficiently reveals who God is. The self-revelation of God in Jesus Christ occurs in the event of reconciliation.

For Barth, light shines on everyone whether they seek the light or hide from it. As the sun shines, rays of its light fall upon all people. "The reconciling work of Jesus Christ is not just accomplished, but has gone out into the reconciled world as a shining light comparable with the leaven hid among three measures of meal (Matt. 13:33). This means that the leavening of the whole" (IV.3, 301/348). Reconciliation for Barth is not a static past event, but continues as a dynamic "shining light." This light is like yeast leavening bread—yet not just the "bread" of Christians — but also "the whole." Through the life, death, resurrection, and ascension of Jesus Christ, true humanity is shown its full capabilities and possibilities. The impact of the event of reconciliation is so powerful and 
so pervasive that "the determination given the world and man in this event is a universal one" (IV.3, 303/349). The event of reconciliation changes our understanding of what it means to be human. The eternal determination is "total" and results in the reconciliation of the world - not just satisfaction of the little flock, or solely the Christian community (IV.3, 301/348). The shining of divine light publicizes the standing of humanity before God. This reconciliation of all humanity with God does not necessarily result in universal salvation, though that is Barth's hope. He believes that the biblical witness teaches universal reconciliation, but stops short of teaching universal salvation. ${ }^{42}$ The impact of Barth's understanding of revelation has an impact on how knowledge is established, how history is understood, and which worldviews are possible.

Just as revelation establishes knowledge, because "Christian knowledge [is] established, awakened, and fashioned by the revelation, manifestation, and prophecy of Jesus Christ” (IV.3, 211/241), so Christ's prophecy “creates history” (IV.3, 212/242). Without the telling of the story, none other than the participants in the event know that it ever occurred. As the primary actor in the event of reconciliation, "Jesus Christ did not become a Witness and Revealer. He was from the very first" (IV.3, 232/266). ${ }^{43}$ Barth's understandings of history and of Christ's activity in reconciliation allow him to assert that Christ was active in reconciliation both at its inception and in its future. Even the event of reconciliation "did not only take place then. It has not become past" (IV.3, 223/256).

The presence of the living Christ within history — both then and now — is what Barth is trying to convey in his title, "Jesus is Victor." All of Christian faith and theology

\footnotetext{
${ }^{42}$ Barth explicitly denies that he is a universalist in $\$ 70$ when he writes, "No such postulate can be made even though we appeal to the cross and resurrection of Jesus Christ. Even though theological consistency might seem to lead our thoughts and utterances most clearly in this direction, we must not arrogate to ourselves that which can be given and received only as a free gift" (IV.3, 477/550).
} 
is a response not only to the written scriptures and the life and death of Jesus Christ, but also to the ongoing self-revelation of Jesus Christ both within, and outside, the walls of the Church. Further, since the prophetic activity of Christ is ongoing, it cannot be domesticated into principles or abstractions. This emphasis on Christ's ongoing prophetic activity fuels Barth's critique of worldviews, since

no world-views (Weltanschauungen) can find any place for Jesus Christ. Of course, they can find room for an abstract God and an abstract man, but not for Him, the God-man. Of course, they can find room for a supposed historical Jesus distilled out of the witness of the New Testament, or for a Christ-idea attained by a similar process of abstraction, but not for the living Lord, for the High-priest, the King and especially the Prophet Jesus Christ. This Jesus Christ is of no value for the purposes of a world-view. He would not be who He is if He were (IV.3, 257/296).

World-views are too static, too abstract, and most importantly, too disconnected from the person of Jesus Christ. They are a human means of trying to understand and contain an idea or concept. For Barth this is no different than the role that religion (or another type of philosophical perspective) attempts to play with Jesus Christ. Humans cannot gain mastery or power over God. The ongoing prophetic activity of Christ cannot be contained or predicted. Any worldview that attempts to do so would be false, unprofitable, and unable to accept the revelatory potential of Christ's ongoing activity.

\section{II.C. \\ Revelation is ongoing}

While Barth believes that the primary vehicle of God's self-revelation occurs in the witness of the scriptures of the Old and New Testaments, he does not believe that revelation is over or finished. Instead, through the ongoing prophetic activity of the risen and ascended God-man Jesus Christ, God's self-revelation continues through cultural

\footnotetext{
${ }^{43}$ See also: Christ "is Victor from the very outset" (IV.3, 229/262).
} 
forms that Christ takes hold of. The reason for this is that the resurrection is not simply the triumphant completion of Jesus Christ's life on earth and the final demonstration of his victory over death. The resurrection marks the beginning of a new phase in Christ's prophetic activity. Even in the resurrection, Barth keeps the movement of prophetic activity moving forward and outward. Barth's use of the threefold office in reference to soteriology offers helpful interpretive insights here. The event of the cross actualizes and discloses God's humiliation and confirms Christ's priestly work of justification. The event of the resurrection enacts humanity's exaltation and confirms Christ's kingly work of sanctification. The event of the ascension actualizes and discloses Christ's prophetic vocation. These events are theologically inseparable in a perichoretic relationship.

Even as the resurrection is a once and for all event, the resurrection is followed by the ascension to confirm its prophetic character (IV.3, 282/326). Christ's resurrection and ascension in $\S 69.4$ acclaims Jesus to be alive, living onward in and through his prophetic activity. Barth began $\S 69.2$ - The Light of Life — with the claim, "Jesus lives." This is the importance of Easter — more than Christmas or Good Friday—that Jesus lives (IV.3, 284/327). Jesus lives and his light can never be extinguished (IV.3, 291/336). The reconciling work of Jesus Christ, in his life, death, resurrection, and ascension, is not just accomplished, but has gone out and is continuing to go out as a shining light, as a fire (IV.3, 301/348). Christ's light, the light of life, is a radiating light (IV.3, 305/353, emphasis added). This light radiates and spreads to all places, peoples, and cultures without regard for whether or not it is received. 


\section{III. \\ Culture}

The starting point for Barth's reflections on revelation and culture is the incarnation of the Son of God in the human flesh of a Jewish Nazarene, Jesus Christ. In this consideration of revelation and culture, §69.2- “The Light of Life," will be analyzed by asking the question: what does it mean that revelation takes place in non-religious parables? Barth's understanding of how revelation occurs, that is, God's self-revelation in Jesus Christ, is very particular. Revelation is always mediated in specific cultural forms, most notably in the person of Jesus of Nazareth. Barth goes to great lengths, particularly in IV.1, to stress Jesus' Jewishness. For Barth this emphasis underlines both that Jesus is human and, more specifically, that Jesus possessed a specific ethnic identity, like all humans, that locates him within God's chosen people of Israel, not some sort of generic human essence. The revelation of God that took place in Jesus Christ occurred within, through, and amidst the Jewish culture of first-century Palestine. The incarnation encompasses a particular culture and history.

By extension, one might say that all ongoing revelation through the prophetic activity of Jesus Christ must also take cultural forms. In §69.2, Barth discusses "true words" and "parables of the kingdom" as two forms of revelation God uses today. Certainly, revelation is always in Christ, by Christ, and from Christ. But revelation is not restricted to the Bible and the Christian community. Barth defines true words as follows: "true words, i.e., words which, whatever their subjective presuppositions, stand objectively in a supremely direct relationship with the one true Word, which are not exhausted by what they are in themselves, which may even speak against themselves, but 
which are laid upon their lips by the one true Word, by Jesus Christ, who is their

Sovereign too" (IV.3, 125/ 141). While it may appear that Barth views true words as an overcoming of culture, I read Barth as valuing cultural forms, including language, preserving their authenticity, while filling them with additional meaning as "true words." In the end, Barth sees a "positive relationship" between "the light of life to the lights" (IV.3, 165/188). Jesus Christ was, is, and will be the light of life (IV.3, 135/153). These lesser lights are not deemed 'revelation' because "no faith is needed to grasp them" (IV.3, 143/161). Meanwhile, the "world as such can produce no parables of the kingdom of heaven" (IV.3, 143/161). Therefore, creaturely truths are only partial truths (IV.3, 159/181), the lesser lights cannot replace the one light of God's self-revelation (IV.3, 153/174), and the little lights are integrated into the one great light (IV.3, 156/178).

\section{III.A. \\ Parables of the Kingdom}

Barth uses the concept of "parables of the kingdom" (Gleichnissen des

Himmelreichs), sometimes translated as "parables of the kingdom of heaven," to explain the relationship of the Light (Jesus Christ) to the lights, in the best known section of $\S 69$ (IV.3, 114-135/128-153). In contrast to the lack of scholarly attention paid to the bulk of $\S 69$ and to Barth’s treatment of Christ as prophet, Barth’s “parables of the kingdom” have received careful scholarly treatment, most significantly as "Secular Parables of the Truth" by George Hunsinger in his Epilogue to How to Read Karl Barth. ${ }^{44}$

\footnotetext{
${ }^{44}$ Hunsinger, How to Read Karl Barth, 234-280. See also: Glenn A. Chestnutt, Challenging the Stereotype: the Theology of Karl Barth as a Resource for Inter-religious Encounter In a European Context (Oxford: Peter Lang, 2010), esp. chapters 3 and 4; Geoff Thompson, "'As open to the world as any theologian could be...'?: Karl Barth's Account of Extra-Ecclesial Truth and Its Value to Christianity's Encounter with Other Religious Traditions" (PhD thesis, University of Cambridge, 1995); Geoff Thompson, "Religious Diversity, Christian Doctrine and Karl Barth," International Journal of Systematic Theology, 8:1 (January
} 
Hunsinger's exposition seeks to correct a misperception that Barth's “exclusivist Christology is incompatible with recognizing truth (i.e. theological truth) in non-Christian sources and writers." ${ }^{45}$ In doing so, he helpfully demonstrates how these "secondary forms of the one Word of God" outside of the scriptures or the Church, drive the community back to the scriptures. ${ }^{46}$ Pace Hunsinger, I do not believe that the qualifier "secular" helpfully captures the significance of Barth's claims about the parables of the kingdom of heaven in §69.2. In fact, in Barth’s Dogmatics, there is only one mention of a "secular parable (Gleichnis profaner)" (IV.3, 115/128). Hunsinger imports the sacred/secular dualism without sufficient textual support from Barth's work. His reading seems to suggest that Barth's holds a strict distinction between the "secular" and the "holy." While the significance of Barth's "parables of the Kingdom" is certainly that God's revelation occurs outside the Bible or the Church, calling everything outside the Church "secular" is obstructive and possibly even pejorative. The parables of the kingdom that Barth describes in $\S 69.2$ are not "secular" per se; it is rather that they occur "in the secular sphere (Profanität)" (IV.3, 117/131). Profanität means all that is profane, that is common or ordinary. The use of profaner or Profanität describes where the parables occur (outside the Christian community), not the character of the parables themselves. The imagery Barth employs then is to encourage Christians to "eavesdrop in the world at large" (IV.3, 117/131) to hear true words that are not directly addressed to the Christian community yet may be beneficial to them to hear.

Appealing to the parable in John 10, Barth suggest that one "hears the voice of the

2006): 3-24; and Tom Greggs, Theology Against Religion: Constructive Dialogues with Bonhoeffer and Barth (New York: Continuum, 2011), esp. chapter 4, 74-98.

${ }^{45}$ Hunsinger, How to Read Karl Barth, 235.

${ }^{46}$ Hunsinger, How to Read Karl Barth, 255. 
Good Shepherd" in parables of the Kingdom (IV.3, 117/131). ${ }^{47}$ Barth's central claim has to do with God's sovereignty in revelation. God's self-revelation through the prophetic activity of Jesus Christ can happen anywhere, not simply within the walls of the church or only through previously sanctioned mediums or oracles. Barth is diminishing the force of the distinction between the church and the world, the so-called sacred and secular-not intensifying the distinction as Hunsinger risks doing. Specifically, Barth is simultaneously trying to disrupt those Christians who have become comfortable and complacent within European Protestant culture while opening the possibility of the work toward political justice for peace, for the poor, etc., by socialists and other left-leaning activists as the work of God's kingdom. ${ }^{48}$ The "parables of the kingdom" then, are not secular in and of themselves but instead underline that parables can still happen today. This is a claim about the ongoing nature of Christ's prophetic activity.

All interpreters would agree that in the New Testament Jesus used parables to explain God's character and intentions in the world. Barth uses "parables of the Kingdom" only twice in his Dogmatics outside of $\S 69$. The first is in IV.2, $\S 64$ to refer to the parables Jesus told in the synoptic gospels about practices of the kingdom of heaven [den Gleichnissen (des Himmelreiches!), IV.2, 174/194]. The second use is in IV.2, §67: where Barth refers to "the synoptic parables of the kingdom (Himmelreichsgleichnisse der Synoptiker, IV.2, 657/744).” The other ten uses of Gleichnissen des Himmelreiches (parables of the kingdom [of heaven]) all appear in $\S 69.2 .{ }^{49}$ There are three uses of Gleichnissen des Himmelreiches outside of the Dogmatics that shed additional light on

\footnotetext{
${ }^{47}$ See also Barth's discussion of John 10 a bit earlier in $§ 69.2$ : IV.3, 95/105-106.

${ }^{48}$ Clifford J. Green, Karl Barth: Theologian of Freedom (San Francisco, CA: Collins, 1989), 43.

${ }^{49}$ See IV.3, 114/128, x2; 117/130-131, x2; 120/134; 122/137; 125/140; 128/145; 130/147; and 143/161.
} 
Barth's use and understanding of the term — in Barth's teaching on the Heidelberg

Catechism (1948), in his tribute to Mozart (1956), and in The Christian Life (1962). ${ }^{50}$

The first use appears in 1948 (in the midst of the writing of Church Dogmatics

III: The Doctrine of Creation), in the publication of Barth's teaching on the Heidelberg

Catechism. In response to Question 28: What advantage comes from acknowledging

God's creation and providence?, Barth writes:

We learn that we are to be patient in adversity, grateful in the midst of blessing, and to trust our faithful God and Father for the future, assured that no creature shall separate us from his love, since all creatures are so completely in his hand that without his will they cannot even move.

Questions 26-27 speak of the objective content of the doctrine of creation and providence. Corresponding to that, we may now speak of the "advantage" on our side. First, there is patience which can wait for the bestowing of God's free grace and endure "in adversity," which holds fast to the fact that God will act in his good time, which does not despair when it sees no parables of the kingdom of heaven. Then there is thankfulness. When the demonstrations of God's free grace happen and become visible, it rejoices not only at the redemption of man but also at his existence in the cosmos and at the existence of the cosmos as such. And it lives and acts in accordance with this joy-even today, in the year 1947! Finally there is trust, which through all contradictions holds to God himself, in everything praising him (his hand!) because nothing in all creation can separate us from him. ${ }^{51}$

Barth is already deploying, a decade prior to the composition of $\S 69.2$, the category of "parables of the kingdom of heaven." Barth may have borrowed the language itself from C.H. Dodd's book The Parables of the Kingdom ${ }^{52}$ that Barth alluded to in a letter to the

\footnotetext{
${ }^{50}$ There are two additional uses outside the dogmatics of minor significance. Barth speaks of some New Testament parables (the Lost Son and the Good Samaritan) as parables of the Kingdom in his 1956 lecture on the humanity of God (Barth, The Humanity of God, 51). Previously, Barth had spoken about theological beliefs translated into political terms as "examples of parables, analogies and corollaries of the Kingdom of God" in his 1946 lecture on "The Christian Community and the Civil Community, §27" in Karl Barth: Theologian of Freedom, 289.

${ }^{51}$ Translated from Die christliche Lehre nach dem Heidelberger Katechismus (Zollikon-Zürich: Evangelisher Verlag A.G., 1948) by Shirley Guthrie in Karl Barth, Learning Jesus Christ through the Heidelberg Catechism (Grand Rapids: Eerdmans, 1964), 62-63, emphasis added.

${ }^{52}$ Barth cited this book as C.H. Dodd, The Parables of the Kingdom (London, 1935) in Karl Barth, "12 Gespräch mit Vertretern der Herrnhuter Brüdergemeinde (12.10.1960)" in Karl Barth Gesamtausgabe:
} 
French Jesuit theologian Jean Daniélou in October $1948 .{ }^{53}$ This usage in his commentary on the catechism points to how parables of the kingdom of heaven can provide hope to a community of faith that God is at work in spite of the present adversity they are facing.

The second usage outside of the Dogmatics comes near the end of Barth's public speech in tribute to Mozart at the Music Hall in Basel on January 29, 1956, the $200^{\text {th }}$ anniversary of Mozart's birth. ${ }^{54}$ Near the end of his speech, Barth remarked:

How can I as an evangelical Christian and theologian proclaim Mozart? After all he was so Catholic, even a Freemason, and for the rest no more than a musician, albeit a complete one. He who has ears has certainly heard. May I ask all those others who may be shaking their heads in astonishment and anxiety to be content for the moment with the general reminder that the New Testament speaks not only of the kingdom of heaven but also of parables of the kingdom of heaven (den Gleichnissen des Himmelreichs) $?^{55}$

Barth refrains from providing such specific examples of a parable of the kingdom in $\S 69.2$. The example of the music of Mozart is as close as he comes. ${ }^{56}$ Barth is hinting that God in Jesus Christ divinely proclaims and reveals an analogy of who God is through Mozart's compositions (IV.3, 73/79). ${ }^{57}$ That is, the distinction between the kingdom of

Gespräche 1959-1962 (GA IV.25), edited by Eberhard Busch (Zürich: Theologischer Verlag Zürich, 1995), 146.

${ }^{53}$ Karl Barth, “An Prof. Dr. Jean Daniélou S.J., Paris, 1948," in Offene Briefe 1945-1968 (GA V.15), edited by Diether Koch (Zürich: Theologischer Verlag Zürich, 1984), 169. Barth and Willem Visser't Hooft also corresponded about Dodd's work both in 1948 and 1957.

${ }^{54}$ Barth's love of Mozart is well-documented. In an article commemorating the $200^{\text {th }}$ anniversary of Mozart's birth in 1756, Barth wrote: "if I ever get to heaven, I shall ask first after Mozart, and only then after Augustine and Thomas, Luther and Calvin and Schleiermacher" in Barth, Mozart, 16.

${ }^{55}$ Karl Barth, "Mozart's Freedom," in Mozart, 56-57. For the German see: Karl Barth, "Mozarts Freiheit," in Wolfgang Amadeus Mozart (Zürich: Theologischer Verlag, 1982), 43; Barth's emphasis.

${ }^{56}$ Barth quipped: "There are probably very few theologians' studies in which the pictures of Calvin and Mozart and of Calvin are to be seen hanging next to each other and at the same height." in Karl Barth, How I Changed My Mind (Richmond, VA: John Knox Press, 1966), 72.

${ }^{57}$ Barth is said to have owned vinyl records of every piece of Mozart's work that had been recorded and fell asleep and was awakened to Mozart's music as well. Barth "died peacefully some time in the middle of the night [from 9-10 December 1968]. He lay there as asleep, with his hands gently folded from his evening prayers. So his wife found him in the morning, while in the background a record was playing the Mozart with which she had wanted to waken him" (Busch, Karl Barth, 498-499). 
heaven itself and parables of the kingdom helpfully differentiates between the sign and the thing signified. ${ }^{58}$ The parables point to the kingdom, but are not the kingdom itself.

The third use appears in the posthumously published The Christian Life that contains drafts of what would have been the first half of Church Dogmatics IV.4. In section §77.2- “Zeal for the Honour of God: The Known and Unknown God," that John Webster describes as "an especially important commentary on $C D$ IV.3." ${ }^{, 59}$ Barth writes:

Should it not also be noted that the concealment in which he does it, which is due to man's blindness, is in fact broken and becomes transparent, if not everywhere, at least in places? When we meet outspoken children of the world, and read expressly secular literature, do we not sometimes at least, quite unexpectedly and to our shame, get the impression that God the Creator does not contradict the contradiction of his creature for nothing? In spite of all the worldliness and unfaithfulness and ignorance of people, does not God in fact see to it that the knowledge of God is not ineffective... that they must know about God and therefore know what they do not want to know or in fact seem to know? Must they not simply because the objective knowledge of God seems to be stronger than all their unfaithfulness and ignorance, because his openness for the world seems to be stronger than its being closed against him? Will not this objective knowledge be at least as strong in places as that mediated to the world through the witness of Christianity? These impressions should not be generalized and systematized along the lines of natural theology, but when they lay hold of us with serious force, they cannot be denied. ...It is also worth noting that Jesus obviously in his addresses - and perhaps this is the authentic commentary on that saying - found very worldly (profane) processes and relations apt and worthy for use as parables of the kingdom of heaven («Gleichnisse des Himmelreichs») (TCL, 121-2/199).

This commentary on IV.3 that Barth provides in $\S 77.2$, highlights the main point of $\S 69.2$ : the revealing of veiled knowledge of God in so-called worldly forms outside the church or the Bible. The source and content of this revelation is the Word of God, Jesus

\footnotetext{
${ }^{58}$ Busch referred to the beginning of Barth's work on IV.3, §69, in 1956 as "a happy coincidence that while Barth was preoccupied with Mozart in this way, his dogmatics lectures (from the beginning of the winter semester he had begun on the material for a new volume, IV.3) were an extended and thoroughgoing discussion of the theological problem of the 'parables of the kingdom of heaven' in the human and earthly realm" (Busch, Karl Barth, 410).

${ }^{59}$ Webster, "Eloquent and Radiant," Barth's Moral Theology, 141.
} 
Christ. Barth names these "processes and relations...parables of the kingdom of heaven" (TCL, 122/199). Barth's claim, by IV.3 and TCL, is that God uses contemporary images (i.e., updated and contextualized from the Sower and the Seed) to reveal who God is.

Always, for Barth, Jesus Christ is the source of revelation; otherwise, they are not "true words," not God's self-revelation. Barth is quite clear that listening for the distinct sound of the Word of God in the secular sphere is not "natural theology" (TCL, 1212/199 and IV.3, 117/131). As opposed to a "natural theology" that allegedly enables a degree of knowledge about who God is to Christians and non-Christians alike, the audience of Barth's parables of the kingdom is those who already have faith in Christ. Similar to the parables of Jesus in the New Testament, ${ }^{60}$ the message, the truth, of the parables of the kingdom is for those with "ears to hear" (Mark 4:9, 23). ${ }^{61}$ At the same time, these parables of the kingdom truly offer, "attestations of the self-impartation [of God]," not "only abstract impartations" (IV.3, 117/131). The truth(s) that is imparted is real, not abstract, and personal, not formal. Certainly, these "attestations" must "be materially tested by and compared with this witness...present in Scripture" (IV.3, 117/131). In these parables of the kingdom, unlike natural theology: "We do not leave the sure ground of Christology" (IV.3, 117/131). Barth appeals to Christ's sovereignty in his resurrection whose witness is "not restricted" to the Bible and the Church (IV.3, 118/131). The unrestricted nature of the freedom of God in Jesus Christ to reveal God is the central meaning of Barth's parables of the kingdom. He states his argument succinctly:

\footnotetext{
${ }^{60}$ Barth expresses the relationship this way: "In sum, the New Testament parables are as it were the prototype of the order in which there can be other true words alongside the one Word of God, created and determined by it, exactly corresponding to it, fully serving it and therefore enjoying its power and authority" (IV.3, 113/126).
} 
Our thesis is simply that the capacity of Jesus Christ to create these human witnesses is not restricted to His working on and in prophets and apostles and what is thus made possible and actual in His community. His capacity transcends the limits of this sphere (IV.3, 118/132).

The significance of Christ's unrestricted revelation is that it can (and does) make other women and men into "His witnesses, speaking words which can be seriously called true" (IV.3, 118/132). The revelation of God in Jesus Christ is not merely informative but is transformative. The words, indeed the very lives, of ordinary human beings are transformed by the living Word of God to be God's witnesses in the "wider sphere" (IV.3, 118/132).

\section{III.B.}

"Secular" and "Periphery"

At this point in his argument concerning the parables of the Kingdom, Barth pauses to ask:

But what is this wider sphere? To whom or what do we refer when we speak of the secular world in contrast with that of the Bible and the Church? If we are to be precise, we must distinguish between a closer and a more distant periphery of this narrow sphere, between a secularism which approximates to a pure and absolute form and another which is mixed and relative. From both, Jesus Christ can raise up extraordinary witnesses to speak true words of this very different order (IV.3, 118/132).

In answering his question, Barth seeks to minimize, if not eliminate, the sacred-secular dichotomy, or rather to prevent it from having any kind of traction. He prefers the imagery of a sphere with a center and a more distant periphery. This unified, unsplittable view of the world allows for degrees of secularization, rather than a strict binary with a distinct secular sphere and a distinct Christian or church sphere.

${ }^{61}$ See Barth's discussion of these texts in IV.3, 112/125. 
Instead of neatly demarcated boundaries, the world is in the church and the church is in the world. While there is "a pure and absolute form" (IV.3, 118/132) of secularism, there is also "a world of mixed and relative secularism" (IV.3, 121/136). What this means for Barth is that "there is no secular sphere" (IV.3, 119/133, emphasis added) that has been abandoned by God. To make such a claim would both limit the power and scope of the resurrection and inhibit one from recognizing the voice of God in the world. For Barth, humans must "be prepared at any time for true words even from what seem to be the darkest places. Even from the mouth of Balaam the well-known voice of the Good Shepherd may sound, and it is not to be ignored in spite of its sinister origin" (IV.3, 119/133). Regardless of the appearance or form of the witness or what appears to be "the darkest places," God in Jesus Christ can and does speak true words of revelation. God does not abandon a so-called "secular sphere" unto itself but instead remains actively present to all humanity.

The revelation of God in Jesus Christ penetrates the entire worldly sphere. Barth develops his imagery of the sphere with Jesus Christ as the center of the circle that constitutes a periphery in order to assert the in-breaking of God's kingdom into human existence. God's prophetic self-revelation in "true words...pierce the secularism of the worldly life surrounding it in closer or more distant proximity" (IV.3, 122/137). This passage reaffirms Barth's point that revelation that occurs through human words comes from and has its origin in the one, solitary Word of God. He writes, "All human words can be true only as [the Word's] genuine witnesses and attestations" (IV.3, 122/137). Further, this indirect revelation is partial and incomplete. Nonetheless this revelation has the power to "pierce the secularism of worldly life" (IV.3, 122/137) both in its 'pure' and 
"mixed" forms. The witness of revelation defines the secularism as secularism, categorizes it as pure or mixed, and constitutes the sphere of divine-human relating by providing its center.

Barth articulates and explains the relationship between the Word and true words, the center and the periphery, by using the term Peripherie (periphery) six times on one page in $\S 69.2$ (IV.3, 122-123/137). He writes,

If we may compare the truth of the one Word of God, which is called and is Jesus Christ, with the centre of a circle and yet also with the whole of the periphery constituted by it, we shall have to say that the revelation of this centre as such and therefore of this whole periphery, now to the faith of believers and one day to the vision of all eyes, can only be His direct Word, whereas all human words can be true only as its genuine witnesses and attestations (IV.3, 122/137).

Barth does not allow the witness of Jesus Christ to be confined to the center, lest he underplay the "outshining" power of the resurrection. While the centrality of revelation constitutes the circle and alone occupies the center, the "truth of the one Word of God" is also found in the whole of the periphery. Though the periphery represents the "secular," even there, the revelation of God in Jesus Christ is present. Barth continues,

But, to take up our illustration, they [true words] are only segments and not the whole of the periphery, and they are certainly not the centre of the circle which constitutes the periphery. They are true words, genuine witnesses and attestations of the one true Word, real parables of the kingdom of heaven, if and to the extent that, unlike segments of other circles with other centres, as true segments of the periphery of this circle they point to the whole of the periphery and therefore to the centre, or rather to the extent that the centre and therefore the whole of the periphery, i.e., Jesus Christ Himself, declares Himself in them (IV.3, 122123/137).

While the parables of the kingdom are found on the periphery, not in the center, they contain and convey the same Word of God as constitutes the center because they are 
products of Christ's self-revelation. These parables communicate true words and are "true segments of the periphery" and their role is to "point to the whole" (IV.3, 122-123/137).

The significance, again, is that "Jesus Christ Himself, declares Himself" in the whole - the center and the periphery. Since Jesus Christ himself is present in the periphery as well as the center, then the true words, the parables of the kingdom, "do not express partial truths, for the one truth of Jesus Christ is indivisible. Yet they express the one and total truth from a particular angle, and to that extent only implicitly and not explicitly in its unity and totality" (IV.3, 123/137). Barth reaffirms that Jesus Christ is THE Light of Life; there is only one truth, not multiple truths. He writes, "they manifest the one light of the one truth with what is from one standpoint a particular refraction which as such is still a faithful reflection of it as the one light" (IV.3, 123/137). Yet, even though revelation through true words and parables of the kingdom is incomplete (does not present the whole picture) the truth that the periphery conveys is not partial, for - to express it tautologically - the truth is entirely true. Barth demonstrates that revelation is ongoing through the prophetic activity of Christ.

Hunsinger helpfully articulates the relationship between the center and the periphery: "whereas the truth of the periphery imparts itself to the center by participating in and manifesting the totality which the center has established, the truth of the center imparts itself to the periphery by filling it and endowing it, at each and every point, with the fullness of uncreated light.." ${ }^{, 2}$ The Light of Christ fills and penetrates the entire worldly sphere, both the center and the periphery. Thus, for Barth, "We must be prepared

\footnotetext{
${ }^{62}$ Hunsinger, How to Read Karl Barth, 262. For Hunsinger's understanding of "uncreated light" in Barth see, "Uncreated Light: From Irenaeus and Torrance to Aquinas and Barth," in Light from Light: Scientists and Theologians in Dialogue, Gerald O'Collins and Mary Ann Meyers, eds. (Grand Rapids: Eerdmans,
} 
to hear, even in secular occurrence, not as alien sounds but as segments of that periphery concretely orientated from its centre and towards its totality, as signs and attestations of the lordship of the one prophecy of Jesus Christ, true words which we must receive as such even thought they come from this source" (IV.3, 124/137). The Christian community can in fact expect revelation in true words to come from secular parables and not simply from the Bible, the Church, or preaching. Why? Because of its encounter with Christ's extravagant light.

At same time, Hunsinger identifies the potential difficulties of navigating this discernment process. He writes, "This point about the contextual ambiguity of secular parables - their immediate context being merely apparent, their true context being veiled though real—suggests the extent to which Barth tends to think in terms of differing contextual wholes that are at once inwardly integral and mutually incompatible."63 These differing contexts serve as containers for revelation in Jesus Christ. In his analysis, Hunsinger retracts his designation of the words and parables of the kingdom as "secular," when he writes: "the real contextual whole in which these words participate is only apparently secular, in reality it is actually Christocentric." ${ }^{64}$ The parables of the Kingdom are not "secular" because they exist under Christ's sovereign rule and as a result of Christ's ongoing prophetic activity. Barth's view of the world is not split into two distinct realms. There is not a worldly, secular realm and a godly, Christian realm. Nor are there a City of God and a City of Man. Nor even a visible and invisible Church. Instead, Barth offers a Christocentric view of the world where Christ is present in and within the entire

2012), 208-235. In his chapter, Hunsinger rightfully claims that, "Barth's controlling metaphor was not creation but resurrection" (222).

${ }^{63}$ Hunsinger, How to Read Karl Barth, 264.

${ }^{64}$ Hunsinger, How to Read Karl Barth, 265. 
created order. Because of Christ, the Church is in the world and the world is in the Church.

At points, Barth presented the prophetic activity of Christ as the response to the decline of the Christian Church. At this point, recall that Barth does not consider Calvin's "re-discovery" of the prophetic office as an accident (literally Zufall, meaning, chance, accident, or coincidence; IV.3, 18/18, 38/40) but as a product of his era. The European reformations themselves point to a need for the outward-facing Christian community to remember the prophetic office of Christ. This need only intensified in the ensuing 450 years as the pace of secularization quickened and intensified. Barth is purposefully talking about the secular, in $\S 69$, as he explicates his Christological understanding of the ongoing prophetic activity of Jesus Christ. The prophetic and the secular are interconnected. The outreaching of prophetic activity permeates the secular realm. But more than that, Christ's ongoing prophetic activity is not bound to a "Christian/Church" realm nor to a "secular" realm; Christ is active everywhere. In fact, the Christian community must pay attention to Christ's prophetic activity in the secular realm to learn from Christ there. In this way, seemingly secular political acts can serve as 'true words' to and for Christians and Christian communities. The "secular" in $\S 69$ serves as a reminder about the political in Barth's writing. The prophetic office of the God-man insists not that Christendom be re-instated but that lives be lived in correspondence to the life and teachings of Jesus Christ in response to God's grace with a vocation of fulfilling Christ's commission of service for others. In $§ 72$, Barth applies his understanding of the ongoing prophetic activity of Christ ecclesiologically as the sending of the Christian community in service for the world. 
While Barth does not even hint at the possibility of primal religious forms being used by God as parables of the kingdom of heaven, we will take up the question in chapter 4 of whether African traditional religions could be considered to be parables of God's self-revelation in Jesus Christ as an expression of Christ's ongoing prophetic activity. Barth's deeply Christocentric account of revelation in the event of reconciliation and the ongoing prophetic activity of Jesus Christ within and outside the walls of the Church allow a reassessment of Barth's understanding of the category of religion, and can reopen the question of revelation and culture.

\section{IV. \\ Religion}

\section{IV.A.}

\section{Real revelation vs. projection}

Barth is aware of the possibility that his claim about Christ's prophetic work might not be revelation, but rather human projection onto the divine. He is, in other words, deeply aware that the critiques of Ludwig Feuerbach must be addressed. Aptly, then, after two pages of comments on Feuerbach in $\$ 17$ (I.2, 290-291/316-317), Barth presents his most sustained treatment of Feuerbach within the Church Dogmatics in $\S 69.2$ (IV.3, 72-85/ 78-94) ${ }^{65}$ Fundamentally, Barth claims that "Immunity against the type of answer given by Feuerbach to his own questions begins with the recognition that these are not our questions and we are quite unfitted to play the role of questioners" (IV.3, 73/80). Barth's initial reply to Feuerbach involves an intense focus on the person of Jesus Christ, not on any principles of the Christian faith. The single focus on the name

\footnotetext{
${ }^{65}$ Barth mentions Feuerbach forty-one times in the Dogmatics. The other significant treatment of Feuerbach is found in $\S 45$ (III.2, 240-241/287-288, 277-278/333-335).
} 
of Jesus Christ, that Barth often emphasizes, is characteristic of his understanding of religion in $\S 17$. Yet, from the perspective of $\S 69$, the concentration on the name almost seems like a principle, such as Barth was trying to avoid in his Christological presentations on The Light of Life (\$69.2) and Jesus is Victor (§69.3). The focus on the name serves as a placeholder in $\S 17$ for the more thorough and fuller exposition in $\S 69$. For Barth, Jesus Christ is "self-disclosing life...eternally repeated and confirmed in the act of His existence as the living God" (IV.3, 80/88). Reading Feuerbach and Barth together converge with the question of religious knowledge. ${ }^{66}$

Feuerbach insists that humans must look inward for God since one's understanding of God is the product of human projection and desire. Barth, on the other hand, insists that humans must look outward for God since one's understanding of God can only come from God's self-revelation in Jesus Christ. In his earliest writing on Feuerbach, part of a 1926 lecture on the history of modern theology given at Münster, ${ }^{67}$ Barth therefore portrayed Feuerbach "as an enemy of theology who is the friend of religion." ${ }^{98}$ However, Barth believes 1) that Feuerbach "is entirely right in his interpretation of religion... [as, quoting Feuerbach,] 'Theology long ago became anthropology,", ${ }^{69}$ and 2) that "Feuerbach's intention is positive," ${ }^{, 70}$ since his desire is to 'make God real and human' by asserting that the object of religion is 'nothing but the essence of man. ${ }^{71}$ 3) Further, he sincerely applauds Feuerbach's understanding of

\footnotetext{
${ }^{66}$ John Glasse, "Barth on Feuerbach," The Harvard Theological Review vol. 57, no. 2 (April 1964): 95. Glasse's article offers a significant and helpful engagement of all of Barth's writings on Feuerbach.

${ }^{67}$ This lecture was later attached as the "Introduction Essay" in the Torchbook edition of Ludwig Feuerbach, Essence of Christianity trans. George Eliot, introduction by Karl Barth, foreword by H. Richard Niebuhr (New York: Harper \& Row, 1957).

${ }^{68}$ Glasse, "Barth on Feuerbach," 72.

${ }^{69}$ Barth, "Introductory Essay," Essence of Christianity, xxix, xix.

${ }^{70}$ Barth, "Introductory Essay," Essence of Christianity, xiv.

${ }^{71}$ Barth, "Introductory Essay," Essence of Christianity, xv.
} 
religion "whose query does nothing less than locate the Achilles heel of modern

theology." ${ }^{72}$ In sum, Barth is deeply gratefully for Feuerbach's penetrating analysis of the "deep shadow" that Christianity has fallen into. Yet he also sees Feuerbach as the final marker in the "sad story (Trauergeschichte)" of Protestant theology in the nineteenth century where at the end theology was "no longer taking itself seriously as theology" (I.2, 290/315, 291/317) ${ }^{73}$

After appealing to Feuerbach to bolster his critique of religion in I.2, §17, Barth offers a deeper engagement in $\S 69$. He pauses in the midst of his presentation of the Light of Life in $§ 69.2$ to ask: "Hitherto we have presupposed and maintained that the life of Jesus Christ as such is light, that His being is also name, His reality truth, His history revelation, His act Word or Logos. We have simply ascribed to Him what the Bible calls glory and therefore His prophetic office. On what ground and with what right may we do this?" (IV.3, 72/79) Barth has Feuerbach in mind here, as he is aware of the possibility that all that is claimed as revelation may not come from God but from humans themselves. He is acutely aware that "we must be very careful how we state and try to answer" this question, lest "[we fall] victim to Feuerbach in our very attempt to resist him" (IV.3, 72/79). Barth's worry, one might say, is that Christians will answer the question, "On what ground and with what right may we do this?" with appeals to human reasoning or to qualities or characteristics in the Christian religion, instead of the "selfwitness which precedes and transcends all our self-witness and by which all our self-

\footnotetext{
${ }^{72}$ Glasse, "Barth on Feuerbach," 72.

${ }^{73}$ Revised translation from Garrett Green, Karl Barth On Religion: The Revelation of God as the Sublimation of Religion (London: T\&T Clark, 2007), 44-45, translating I.2, 291/316, Barth's emphasis. The quotations from $\S 17$ that follow are taken from Garrett Green's translation. The page for Green's translation is listed last, preceded by the page numbers in the English translation and original German editions of the Dogmatics, i.e. (I.2, 291/316; 44-45).
} 
witness must be orientated" (IV.3, 73/80). Responding to the question he posed and his fears surrounding possible answers, Barth then seeks to change the question itself. If a theologian intends to remain true to her calling as a Christian theologian, then "there can be no possible answer in the spirit and along the lines of Feuerbach" (IV.3, 78/86). Feuerbach's questions are primarily about the nature of humanity while, for Barth, theology begins from a position of having been encountered by God in God's selfrevelation. Feuerbach reversed the process; Barth aims to reverse the reversal.

The only possible ground to maintain "that the life of Jesus Christ as such is light, that His being is also name, His reality truth, His history revelation, His act Word or Logos" (IV.3, 72/79) is the self-witness of God in the prophetic activity of Jesus Christ. If revelation is the starting point, and indeed the sole "point-of-contact" for all theological and religious reflection, including the Christian religion itself, then "Questions like that of Feuerbach will not be even remotely possible. Considering and taking seriously the fact that God is present and active, we have renounced all such questioning from the very outset" (IV.3, 80/87). Barth is appealing to a God in Jesus Christ who is neither silent nor mute, but eloquent, neither withdrawn nor dull, but radiant. In the end, for Barth, "The good confession of the prophecy of Jesus Christ is both legitimate and obligatory for us. We can venture it without embarrassment, and need to be afraid of no Feuerbach" (IV.3, 85/94). Thus, Barth sees the dangers and the appeal of basing theological reflection on the human apprehension of revelation, not God's self-revelation itself.

\section{IV.B.}

Person vs. Principle: Reading I.2, §17 in light of IV.3, §69

For Barth, the work of Jesus Christ accomplished in the event of reconciliation is 
self-revealing and also establishes knowledge, that is, "Easter knowledge" (IV.3, 283/327). On this reckoning, as Barth foreshadowed in his exegesis of Genesis 3:4-5 in I.2, $\S 17$, knowledge of God cannot come from within a person or religion. Barth contrasts the serpent's advice for humanity to come-of-age by asserting independence from God (IV.1, 435/482), with his hope that humanity—as individuals and as the Christian community—will practice dependence on God and God's self-revelation, that they will "come of age in relation to God and the world, i.e., the mature Christian and mature Christianity, its thought, speech and action in responsibility to God, in living hope in Him, in service to the world, in free confession and in unceasing prayer" (IV.4, preface, x). These more personal words demonstrate Barth's concern from the beginning: the external revelation of God in Jesus Christ is the only sufficient basis for the Christian life and a Christian religion. Knowledge of God can only come from God's self-revelation. So, as "atonement takes place... it is also revelation establishing knowledge...[This] Christian knowledge [is] established, awakened, and fashioned by the revelation, manifestation, and prophecy of Jesus Christ" (IV.3, 211/241). All knowledge of reconciliation is grounded in the event of revelation (IV.3, 213/243). As opposed to the static "name of Jesus Christ" from §17, "the living Lord Jesus, is the theme and basis and content of Christian knowledge" (IV.3, 212/242). The content of this knowledge narrates a "present history" (IV.3, 233/267) because "Jesus Christ exists" (IV.3, 236/270) in the present through Christ's ongoing prophetic activity. ${ }^{74}$

In I.2, $\S 17$, the story of the Church's relationship with Empire can only be told alongside the "sad story (Trauergeschichte, I.2 291/316)" of the gradual emergence of religion as "an independent known quantity alongside revelation" until at last "religion is

\footnotetext{
${ }^{74}$ Here, it is worth recalling Barth’s early assertion in §69.2-“He, Jesus Christ, lives” (IV.3, 39/41).
} 
not to be understood from the point of view of revelation, but rather revelation from that of religion" (I.2 291/316, 44-45). The reversal of the proper ordering of religion and revelation results in the theological task losing its object. Instead of studying and reflecting upon revelation, this history of Christianity "maturing" or "coming-of-age" is one of theology trading revelation for religion, to its detriment. Theology's "catastrophe" is "that it lost its object, revelation, in its particularity and with it the mustard seed of faith by which it could have moved mountains, even the mountain of humanistic culture. That it really lost revelation is shown by the very fact that it was possible for it to exchange revelation, and thereby its own birthright, for the concept of religion" (I.2, 293/320; 49). Barth appeals to the Genesis account of Esau exchanging his birthright as the firstborn for a bowl of stew. The language of birthright — that revelation is theology's own birthright—is significant. This birthright is what offers the possibility of Christianity as the true religion. Only through attending to God's self-revelation in Jesus Christ is a true religion possible. Barth affirms this view in the concluding sentence of $\S 17.1$ : "Remembering the Christological doctrine of the incarnation, and applying it logically, we speak of revelation as the sublimation (Aufhebung) of religion" (I.2, 297/324; 52). Barth offers primarily a theological understanding of religion, not a sociological one. These definitions are held constant in $\S 69$ where each of Barth’s claims, about Jesus Christ, the Word of God, and Christianity as a religion have "really nothing whatever to do with the arbitrary exaltation and self-glorification of the Christian in relation to other men, of the Church in relation to other institutions, or of Christianity in relation to other conceptions" (IV.3, 91/100). Barth's interest is in Jesus Christ, the one Word of God. 
Barth's understanding of religion is shaped and normed by his understanding of Jesus Christ. Here Green's translation of Aufhebung as sublimation, not abolition, is important. The coming of Jesus Christ, in Barth's understanding, does not abolish or eliminate religion. Barth understands the necessity of true religion as the human expression of the body of Christ on earth. The coming of the Son of God in human flesh does not leave religion untouched. In fact, all human religion is subject to God's judgment. Barth writes, "In the sphere of reverence before God, the reverence before human greatness must always have its place; it is subject to God's judgment, not ours" (I.2, 301/328; 56). ${ }^{75}$ As $§ 17$ makes clear, all religion is under God's judgment as human attempts at greatness. Only when revelation is not contained within religion, is true religion possible. True insight, wisdom, and power cannot come from within a human or humankind. Instead, Barth writes, "Only from a place outside the magic circle of religion, along with its place of origin — that is, only from a place outside of man — could this real crisis of religion break in" (I.2, 324/355; 83).

This is the sense in which Barth's comment on the opening page of $\S 17.3$, "The True Religion," is to be understood. When Barth writes: "No religion is true. A religion can only become true" (I.2, 325/356; 85), he is reaffirming the external validation for a religion and the impossibility of a religion justifying itself. For Barth, a parallel to a religion's attempt at self-justification is a human's, a sinner's, attempt at the same. Just as a sinner cannot justify himself, neither can a religion. Further, as a sinner could not even stop being a sinner, so too a religion can never get outside of God's judgment. For Barth, since "Religion is never and nowhere true as such and in itself," talking about "true

\footnotetext{
${ }^{75}$ Green notes that this "aspect of Barth's theory of religion is especially important for religious studies, since it clearly precludes the frequent tendency to dismiss Barth as a detractor of religion or as a Christian
} 
religion" can only be done in the sense of a justified sinner (I.2, 325/356; 85). For Barth, neither of these pairings is an oxymoron, instead, they are theological realities. In "the linchpin of his theological theory of religion," ${ }^{, 76}$ Barth writes:

There is a true religion: just as there is a justified sinner. As long as we remain strictly and precisely within this analogy - and it is more than an analogy, for in the broad sense it is the very matter we are dealing with here-we must not hesitate to state that the Christian religion is the true religion (I.2, 326/357; 85).

This true religion, in other words, is predicated on God's self-revelation. Though Barth is, of course, quick to point out that God's freedom in revelation is in no way hindered or bound because the religion of Christianity is based on it. Thus, "The religion of revelation [Offenbarungsreligion] is indeed bound to God's revelation, but God's revelation is not bound to the religion of revelation" (I.2, 329/360; 88-89). All other religions "appeal to this or that truth inherent in themselves. ... [While] Christianity can take part in this struggle... it has then renounced its very birthright, the unique power accruing to it as the religion of revelation" (I.2, 333/364-365; 93). Barth again uses the language of "birthright" to describe Christianity's unique relationship to revelation.

Barth chooses an Asian religion to further his point about the uniqueness of Christianity as the true religion. In a five-page excursus (I.2, 340-344/372-377), Barth describes Pure Land Buddhism as "the most exact, comprehensive, and plausible 'pagan' parallel to Christianity" (I.2, 340/372; 101). Yet, this excursus has more to do with the uniqueness of Christianity through the name of Jesus Christ, than that of Buddhism or any other religion. The bottom line for Barth is that while Pure Land Buddhism may have grace, it does not have Jesus Christ, so it is not true religion. The point that Barth is 
making is that "The Protestant Christian religion of grace is not the true religion because it is a religion of grace ... among the religions only one thing is decisive concerning truth and falsehood. That one thing is the name Jesus Christ" (I.2, 343/376; 105). Grace alone in a religion is not enough to mark it as a true religion. Here in $\S 17$, Barth is very clear that a true or false religion can quickly and easily be determined by the absence or presence of the name Jesus Christ. He writes, "The name Jesus Christ creates the Christian religion, and without it it would not exist" (I.2, 346/380; 109). In §69, insisting on the mere presence of the name of Christ will be treated as a principle that insufficiently captures the story/history of Jesus Christ. Barth also employs the imagery of light that will be further developed in $\S 69$, but does not hint at how the munus duplex in $\S 17(\mathrm{I} .2,360 / 396 ; 124)$ is expanded to the munus triplex in $\S 69$. The priestly justification and the kingly sanctification do not yet have the prophetic vocation to call them forward. As a result, in $\S 17$, Barth operates with a less dynamic understanding of revelation than that of $\S 69$.

In $\S 17$, "truth" operates as an abstract category that is connected to the name of Jesus Christ. In $\S 69$, the notion of truth is embodied in the history (Geschichte) of the Son of God — the Word of God from the beginning — who brings life to all. The "reconciling work of Jesus Christ, is not just accomplished, but has gone out into the reconciled world as a shining light... a fire" (IV.3, 301/348). The insight that reconciliation is revelation in $\S 69$ points to a dynamic understanding of the role of Christ in reconciliation; the gospel is continually outgoing and outshining. The work of reconciliation was not stopped on Golgotha. While the life, death, resurrection, and ascension of Jesus Christ is sufficient for humanity to be reconciled to God, the work of reconciliation continues in and through 
the ongoing prophetic activity of Jesus Christ. Succinctly, "reconciliation carries with it a call to advance!" (IV.3, 315 rev./363). This call forward points to the dynamic character of revelation that gives life and meaning to true religion.

Thus in contrast to the very exclusive language about true religion at the end of $\S 17$, where Barth connected Christ's name to revelation as: "the revealed fact of God in the name Jesus Christ," the defining characteristic of a true religion (I.2, 355/390; 118); Barth is now making inclusive statements about how "the real goal and end of the resurrection of Jesus...was the reconciliation of the world and not just the satisfaction of the little flock of believers" (IV.3, 303/350). Yet, two observations are in order: 1) Barth's changed focus from religion to reconciliation may account for the change from exclusive to inclusive claims. After Barth's placement of the doctrine of election within the doctrine of God in II.2, Barth's dogmatics proclaimed universal reconciliation for all in Jesus Christ-something that religion alone could not achieve. 2) Barth's understanding of reconciliation is totalizing —all peoples in all times and places are reconciled to God in Jesus Christ. His view is inclusive, yes, but perhaps too forceful. He writes, "the determination given the world and man in this event is a total one... a universal one" (IV.3, 301/348, 303/349). While some may find Barth's understanding of universal reconciliation comforting and generous, and others may find it a violation of human agency, Barth seeks to preempt all such concerns. For him, Jesus Christ and Jesus Christ alone have defined humanity. And, living in correspondence with one's reconciled humanity is what it means to be human. Just as "the Easter event is grounded the necessity of Christian mission" (IV.3, 304/351), so to Christians and the Christian community are to follow Christ's "radiating light" (IV.3, 305/353) outward in service of 
others. In contrast to §17's exclusive claims to a privileged club, known as Christianitythe true religion - the outward, radiating movement of Christ's prophetic activity invites everyone to join the forward movement.

\section{V. Implications}

Barth's understanding of the ongoing prophetic activity of Jesus Christ helps to counter two commonly held misconceptions. Some Evangelicals, particularly in the U.S. (but not only here), criticize Barth for his understanding of Scripture. Specifically, they critique Barth's understanding that Jesus Christ is THE Word of God and that the Bible contains the Word of God-as Jesus Christ revealed in the written words of the scriptural text. ${ }^{77}$ The critique more specifically is that Barth offers a "relativistic" understanding of scripture. Because the biblical texts are not objectively the word of God (as it taught under the heading of a restrictive account of biblical inerrancy) then anyone can interpret the Bible in any way. ${ }^{78}$ In contrast, postcolonial theologians, among others, accuse Barth of portraying God as too distant and aloof. ${ }^{79}$ This God is insufficiently relational and imminent and fails to adequately enter in to the pain, suffering, and difficulties that humans experience in their everyday lives.

The reasons informing these interpretations are twofold. First, many of Barth's critics have only read selections of Church Dogmatics I.1. This selective reading offers

\footnotetext{
${ }^{77}$ The work of Cornelius Van Til first offered a number of these critiques and serves as a precedent for them.

${ }^{78}$ See D.A. Carson's Gagging of God: Christianity Confronts Pluralism (Grand Rapids: Zondervan, 1996), for just one prominent example. Byung Kato is the foremost African theologian articulating this critique.

${ }^{79}$ See Mayra Rivera, The Touch of Transcendence: A Postcolonial Theology of God (Louisville:

Westminster John Knox Press, 2007), 4-5.
} 
but a partial view of Barth's theology ${ }^{80}$ Contributing to this partial reading for Englishlanguage readers was the initial lag and order of publication of the Church Dogmatics translated into English. After volume I.1 appeared in English in 1936, twenty years passed before an additional volume appeared. In 1956, volumes I.2 and IV.1 were published in English; by 1961, all eleven completed part-volumes had been translated and published in English.

Barth’s insights in $\S 69$, over 7000 pages and twenty-five years later than his initial thoughts in I.1, offers a presentation of the ongoing prophetic activity of Jesus Christ that addresses both concerns in interesting ways. For some evangelicals, whose broader theological concerns were of interest to Kwame Bediako, Barth's consistent and explicit Christological exposition based in detailed arguments of Biblical exegesis might go some way to assuaging their worries about Scripture. Further, the ongoing prophetic activity of Christ presents the underlying thrust for the sending of the Christian community in $\S 72$ that offers a profound theological rationale for mission and evangelism. John Flett goes so far as to argue that mission should be placed within the doctrine of God. ${ }^{81}$

For postcolonial theologians and others with similar concerns, the prophetic nature of Christ's ongoing activity and the universality of divine-human reconciliation and revelation that Barth articulates in $\S 69$ might be deemed significant and helpful resources. The witness of Christ that counters human claims to power, and relativizes all worldviews, results from Christ's ongoing prophetic activity. God in Jesus Christ is at

\footnotetext{
${ }^{80}$ As occurred for Bediako, who was only exposed to excerpts of Church Dogmatics volumes I and II in his Modern Theology course at London Bible College. For more see chapter 2.

${ }^{81}$ John Flett, The Witness of God: The Trinity, Missio Dei, Karl Barth, and the Nature of Christian Community (Grand Rapids: Eerdmans, 2010).
} 
work in the world, especially on behalf of those on the underside of power. Barth clearly establishes that the Biblical understanding of Christ as prophet undermines and critiques the practices of European colonization and missionary activity. Barth writes, "He [Jesus Christ] would have contradicted them, showing to the world and men only the kind of lop-sided favour which European nations used to exercise without consulting them to the peoples of their colonies" (IV.3, 333/384). Indeed, at one point, Barth asserts that Jesus Christ is on the side of the colonized, not the colonizers. Barth's understanding applies not only to the past errors of formal colonization in the nineteenth and twentieth centuries but also to the practices of theological reflection in the present-day. He writes,

Likewise the debate about whether the aim of the mission should be to represent a European-American Christianity or to found an autochthonous African or Asian Christianity could not remove the hidden problem that either way it was still a matter of the "glory' [Ruhm, "fame"] of one Christianity or the other in its relation to the needs and postulates of man. Nevertheless, in this third period on the Christian west as well, and in the mission fields, the truth of Christianity, the grace of Jesus Christ in the spiritual poverty of those who believed in him even in this period did not fail to speak, shine forth, and to assert itself (I.2, 336/368; 97, my emphasis).

From this early expression in I.2, $§ 17$ of his views of the failure of Christianity as a religion, Barth sketched his hopeful understanding of the possibilities that could result as "the grace of Jesus Christ...[would continue] to speak, shine forth, and assert itself" (I.2, 336/368; 97). Barth's exposition of the ongoing prophetic activity of Jesus Christ in IV.3, $\S 69$, expanded and filled-out these nascent thoughts by reformulating Barth's understanding of revelation, religion, culture, and their inter-relationship.

Further, as will be considered in more detail in chapter 4, Barth's understanding of true words and parables of the kingdom offers intriguing possibilities for engaging indigenous religious knowledge systems. 


\section{Chapter 4 \\ Two Christocentric Theologies}

In the beginning was the Word, and the Word was with God, and the Word was God. He was in the beginning with God. All things came into being through him, and without him not one thing came into being. What has come into being in him was life, and the life was the light of all people. The light shines in the darkness, and the darkness did not overcome it. There was a man sent from God, whose name was John. He came as a witness to testify to the light, so that all might believe through him. He himself was not the light, but he came to testify to the light. The true light, which enlightens everyone, was coming into the world...And the Word became flesh and lived among us, and we have seen his glory, the glory as of a father's only son, full of grace and truth. - John 1:1-9, 14

Long ago God spoke to our ancestors in many and various ways by the prophets, but in these last days he has spoken to us by a Son, whom he appointed heir of all things, through whom he also created the worlds. He is the reflection of God's glory and the exact imprint of God's very being, and he sustains all things by his powerful word. When he had made purification for sins, he sat down at the right hand of the Majesty on high, having become as much superior to angels as the name he has inherited is more excellent than theirs. - Hebrews 1:1-4

Having described and analyzed the work of Kwame Bediako in chapter 2 and the mature Christology of Karl Barth in Church Dogmatics IV.3, §69 in chapter 3, here in chapter 4 , the insights of these two theologians are put in conversation about revelation, religion, and culture. Bediako's "theology of négritude," based on the twin heritage of African Christianity - the pre-colonial African religious past and the pre-Christendom Christian apologists - raised a number of themes that require more detailed analysis through a comparison with Barth's thought. Equally, Barth's understanding of the ongoing prophetic activity of Jesus Christ needs to be examined with respect to the present, considering specific examples that Barth was reluctant to provide. 
188.

Before engaging the specifics of the comparison, the chapter begins with an exploration of these theologians' shared focus on Jesus Christ. Both Bediako and Barth understood themselves as offering a Christocentric approach to theological reflection. Barth's approach will be addressed first, then Bediako's.

Barth was quite clear that his theological approach was Christocentric (focused on Christ) without being Christomonistic (focused solely on Christ). ${ }^{1}$ In a question and answer period as part of the final session of his 1962 Warfield lectures at Princeton Theological Seminary, Barth's response to a questioner on this topic is incisive. He was asked: "In what specific way, Professor Barth, does your theology avoid being Christomonistic?" He replied,

Sound theology cannot be either dualistic or monistic. The Gospel defies all 'isms,' including dualism and monism. Sound theology can only be 'unionistic,' uniting God and man. Christomonism (that's an awful catchword!) was invented by an old friend of mine whose name I will not mention [likely C.G. Berkouwer's Barthianisme en Katholicisme, his 1940 inaugural address as extraordinary Professor in the Theology Faculty, Free University, Amsterdam]. Christomonism would mean that Christ alone is real and that all other men are only apparently real. But that would be in contradiction with what the name of Jesus Christ means, namely, union between God and man. This union between God and man has not been made only in Jesus Christ but in him as our representative for the benefit of all men. Jesus Christ as God's servant is true God and true man, but at the same time also our servant and the servant of all men. Christomonism is excluded by the very meaning and goal of God's and man's union in Jesus Christ. ${ }^{2}$

Barth thereby rejects Christomonism as an abstraction (an -ism) that distorts both the divine-human unity in Jesus Christ and the true humanity of all human beings. He states it succinctly: "Just as there can be no anthropomonism, so also can there really be no

\footnotetext{
${ }^{1}$ See Barth's three comments on Christomonism in his Church Dogmatics: III.3, preface; IV.3, 713/793; and IV.4, 23/25.

${ }^{2}$ Karl Barth, “A Theological Dialogue,” Theology Today 19/2 (July 1962): 172. The parenthetical note about Berkouwer was added by Theology Today.
} 
christomonism." Additionally, Barth's repeated Trinitarian emphases mitigate against critiques of Christomonism. This understanding of God's self-revelation is that the fullness of the Godhead — in three modes-of-being, Father, Son, and Holy Spirit — is revealed in the person of Christ.

Because of their diverse contextual circumstances, Bediako encountered different challenges and questions. He was never forced to consider the differences between Christocentrism and Christomonism, as Barth had been by Berkouwer. Repeatedly, his concern was to articulate his focus on Jesus Christ in contrast to movements he viewed as syncretistic, such as Afrikania (CiA, 17-38), or non-Christian, such as ATR. A singular focus on Jesus Christ was an evangelical badge of honor, not a possible source of error. Bediako's widow, Gillian Mary Bediako, captured this stance well in response to my comment about his remarkable consistency in his thought throughout his career. She replied, "Of course. His focus was on Jesus Christ and he never strayed."4 The assumption was that such a focus on Christ inherently provided Bediako with appropriate boundaries and direction in his work. As much as his approach might be viewed as unreflective or uncritical, it is certainly unapologetic and unswerving.

As Biblical sources for their Christological reflection, both Bediako and Barth spent quite a bit of time and space exploring the prologue to the Gospel of John and the Epistle to the Hebrews. As will be discussed in section II below, Bediako's Christology is based more in Hebrews with reference to John; Barth's Christology is based more in John and then connected to Hebrews, particularly the exordium. Bediako emphasized Christ's

\footnotetext{
${ }^{3}$ Karl Barth, "Extra Nos_-Pro Nobis-In Nobis" in Hören und Handlen, Festschrift für Ernst Wolf zum 60. Geburtstag, ed. Helmut Gollwitzer und Hellmut Traub (Munich: Chr. Kaiser Verlag, 1962), 15-27; quoted from George Hunsinger's translation in The Thomist 50:4 (October 1986): 511.

${ }^{4}$ Personal interview 5 August 2013, Akrofi-Christaller Institute, Akropong-Akuapem, Ghana.
} 
high-priestly role and the connection of Jesus Christ to the ancestors-both Israelite and African. Barth emphasized the person of the Word of God and the incarnation of the Word as the God-man Jesus Christ.

Although both John 1 and Hebrews 1 are known for focusing more on the divine aspects of Christ than the human, Barth does not allow his understanding of the second person of the Trinity to be separated from the concrete human being, Jesus Christ. Bruce McCormack describes Barth's understanding as follows:

John 1.1, then, does not refer to an eternal Word abstracted from the humanity He would assume in time but to Jesus Christ and, therefore, to a Word whose identity is given through the relation in which He stands to Jesus of Nazareth. Jesus Christ is simply called 'the Word' in v.1 because $\mathrm{He}$ is the Revealer, the personal address of God to those who live in darkness. $^{5}$

More than one hundred times in the Church Dogmatics (including eight times in IV.3, §69), Barth cites John 1:14: "And the Word became flesh and lived among us, and we have seen his glory, the glory as of a father's only son, full of grace and truth." ${ }^{\prime 6}$ The sixpage excursus in $\S 69.3$ on the history of the prophecy of Jesus Christ (IV.3, 231-237/265271), demonstrates the importance of the Gospel of John to Barth's entire project in IV.3, and in $\S 69$ in particular. Barth writes,

It is especially relevant that we should consider the verdict of this Gospel in the present context because the terms Word, light, revelation, speech and witness denote the specific angle from which the history of Jesus Christ is seen and recounted in this Gospel. Epigrammatically, we might almost say that the Gospel of John is the Gospel of the Gospel itself, i.e., of the prophetic work of Jesus Christ (IV.3, 231/265, emphasis added).

Barth cites John 1:14, three times in the space of these six pages, both to emphasize the union of God with human flesh in the person of Jesus and to point to the glory

\footnotetext{
${ }^{5}$ McCormack, "The Identity of the Son," 157.

${ }^{6}$ See IV.3, 48/52; 232/265. 266; 235/269, x2; 236/271; 293/338; and 301/347.
} 
(remembering here the connection Barth drew between glory and light), "full of grace and truth," that is visible in the incarnate Son. As Barth understands it, "the Johannine description points from above downwards to the human being of the eternal Son of God" (IV.2, 156/174). The origin of the incarnate Son and of revelation itself comes from God above.

Barth finds in the Gospel of John, then, the very rationale for the prophetic office of Jesus Christ; ${ }^{7}$ whereas Bediako finds in Hebrews the rationale for Christ's sole mediatorship and priesthood as well as his ancestor Christology. Along the way, Barth buttresses his case using the intertwining themes of sonship and priesthood in Hebrews, while Bediako uses “the early verses of John's Gospel...[to] insist of the primacy of Jesus' universality." ${ }^{\prime 8}$ In many ways, their particular emphases here, while articulated and defended theologically, can also be viewed in light on their respective contexts. It is not surprising that Barth's theological exposition of the doctrine of reconciliation culminates in a presentation on Jesus as Prophet after Barth spent a lifetime seeking to be a witness to Christ in the political arena. Neither is it surprising that Bediako's work focuses on mediation (as priesthood), as much of his argument is intended as an attack on the history of the indirect communication of the gospel to Africans by Europeans and a defense of the direct communication of the gospel through its infinite translatability. As always for both, the proclamation of the gospel occurs in specific cultural settings.

Having established the similarities in Christological concentration between Bediako and Barth, the chapter moves next to compare each theologian's understanding

\footnotetext{
${ }^{7}$ More generally, Barth identifies Jesus Christ with the prophetic office by citing the biblical witness: John 6:14, 1 Timothy 2:16, 2 Corinthians 1:20 (IV.3, 12/11-12).

${ }^{8}$ Bediako, "Biblical Christologies in the Context of African Traditional Religions," 101; and JAC, 25.
} 
of the universality of Christ - its basis and repercussions for his thought. The second section engages the method and reasoning each theologian brings to reading the Epistle to the Hebrews. The third section specifically compares Bediako's and Barth's understandings of the three themes coursing through this dissertation-revelation, religion, and culture. The final section applies their understanding of these themes collectively to engaging questions of theology and culture today under the heading: Are we all syncretists?

More purposefully, in this chapter I argue that Bediako's understandings of African Christianity and traditional African religions offer an invaluable occasion to test, and perhaps modify, Barth's thought, and to appreciate still more fully Bediako's significance for constructive Protestant theology today. Might Barth's articulation of the ongoing prophetic activity of Jesus Christ provide a way of thinking about God's selfrevelation through traditional African religions as described by Bediako? Are traditional African religions "parables of the Kingdom"? Do they convey "true words" of revelation in Jesus Christ?

I.

\section{The Universality of Christ}

The revelation of God in Jesus Christ is available to all peoples through the universality of Christ for both Bediako and Barth. Yet, the reasoning each theologian uses to inform his understanding of Christ's universality is significant and revealing. The first sub-section considers Bediako's understanding of universality through Christ's

divinity. The second sub-section engages Barth's understanding of universality through Christ's resurrection. 


\section{I.A. \\ Bediako: Universality through Christ's Divinity}

As expressed in the opening epigraph in chapter 1, for Bediako, "The needs of the African world require a view of Christ that meets those needs" (JAC, 22). His claim, specifically, is that the New Testament (especially, as will be shown in section II, "Reading the Epistle to the Hebrews") makes clear the connection between Jesus Christ—as a non-African — and African peoples. Bediako's underlying assumption is that Jesus Christ is the "Universal Saviour" (JAC, 20; Bediako's emphasis). By "Universal," Bediako means that Jesus Christ has value, relates to, and has significance for all peoples, including Africans. He is not here differentiating between Christ's person and work; instead he is suggesting that Africans can think differently about their relationship with a non-African claiming to be God. At the same time, there is a potential problem. While Bediako claims that traditional African religions are continuous with Christianity (one God with different mother-tongue names, revealed in part through traditional religions and more fully in Jesus Christ), and connects Africans with the Father and the Spirit, Jesus' Jewishness seems to complicate the relationship between Scripture and African cosmology and religiosity.

The reason is as follows: African spiritual communities consist of one's family, clan, tribe, and nation —often based on linguistic groupings. As opposed to many contemporary Western individuals, many Africans, and certainly the Akan, consider themselves part of a community from their birth, a spiritual community. J.B. Danquah describes Akan religion (the largest ethnic group in Ghana and Côte d'Ivoire), in this way:

In a word, Akan religion, in its highest expression, is the worship of the 
race. This race has a universal possibility, being dividual (sic) and therefore divine, coeval (sic) with the very reason that makes it ultimate with reality and organic with the unity of the ultimate. ${ }^{9}$

Bediako, as an Akan himself (as is Danquah), worried about how to relate to the Godman Jesus of Nazareth who is most certainly not an Akan. The religion of the Akan is particularly ethnocentric; Danquah puts it bluntly: "Akan religion... is the worship of the race. ${ }^{10}$ How, then, can an Akan worship one who is not of his race? How can Jesus Christ join in this "unity of the ultimate," as Danquah describes it, if he is an outsider to Akan religion? Akan ancestors come from within the clan and are understood to intercede in the lives of individuals and the clan as a whole. Akan religious rituals implore the ancestors (who are also Akan) to work with Nyame (the Akan name for God) for the health and prosperity of the Akan people.

The challenge, as Bediako understood it, was to connect Jesus to Africans so that Africans could relate to God's Son who is not of their tribe. He wanted Christ to be the fulfillment of ATR in the same way that he understands Christ to be the fulfillment of ancient Israelite religion and the Old Testament. To meet this challenge, Bediako emphasized Christ's divinity — his Spirit that has been present in Africa for thousands of years-over the humanity of Jesus' non-African flesh. Instead of identifying Africans as Gentiles, similar to Paul in Galatians, Bediako desired a more primal relationship with God — similar to the relationship that Jewish people have — to worship God as a member of their ethnic group. To make this move, Bediako downplayed Christ's Jewishness. ${ }^{11}$

\footnotetext{
${ }^{9}$ Danquah, Akan Doctrine of God, 169.

${ }^{10}$ Danquah, Akan Doctrine of God, 169.

${ }^{11}$ There is a long and sordid history of efforts by Christians to extract or minimize Jesus's identity as a Jew. As sympathetic as one might be to Bediako's motivations, there remain substantive theological reasons to object on this matter. See, for example, J. Kameron Carter, Race: A Theological Account (New York: Oxford University Press, 2008).
} 
195.

Bediako's belief in Christ's universality leads him to make this point explicitly: "Jesus Christ is not a stranger to our heritage" (JAC, 24). He overcomes the gap between Christ and Africans by "starting with the universality of Jesus Christ rather than from his particularity as a Jew, and [by] affirming that the Incarnation was the incarnation of the Saviour of all people, of all nations and of all times" (JAC, 24). Years later Bediako reaffirmed his view in an interview. Roar Fotland recounted Bediako's emphasis on Christ's divinity: "Bediako thinks that it is the divinity of Jesus that is the point of contact with the universality of Jesus. Therefore, to start with his divinity is to make him universal. If I start with him as human, Bediako said, I have to see him as a Jew and will have problems accepting him as an Akan ancestor. Jesus needs to be human first in order to live, and die in order to become an ancestor, but as a universal ancestor he must communicate from the other side." 12 The question for Bediako, then, is not merely theoretical but practical-that is, apologetic concerns motivate his theological inquiry.

Since Jesus was not a Levite, but of the tribe of Judah, how could he be a priest? The fundamental question is analogous for early Jewish Christians and for contemporary Africans: how do you relate to one of a different tribe? Jesus became a priest not through Aaron, but through Melchizedek. Aaron was a high-priest of the tribe of Levi-the tribe that served in particularly priestly roles on behalf of all twelve tribes of Israel. The ancestry of Jesus of Nazareth, as told in Matthew 1, is traced back not to Levi, but to his brother Judah. The Epistle of the Hebrews explains how Jesus, a non-Levite, can be a high priest by asserting the priesthood of Jesus Christ, "according to the order of Melchizedek" (Hebrews 5:10. 6:20, 7:1-17). Melchizedek is described in Genesis 14:18,

\footnotetext{
${ }^{12}$ Roar Fotland, "Ancestor Christology in Context: Theological Perspectives of Kwame Bediako," (PhD dissertation, Bergen: University of Bergen, 2005), 292-293.
} 
as a "priest of God Most High." This is the only time in the Hebrew Bible that a nonLevite is referred to as a priest. The only other mention of Melchizedek in the Bible, outside of Hebrews and Genesis 14, occurs in Psalm 110:4, when David writes that the Lord will not change his mind in regards to Melchizedek's priesthood. Based on the presence of Melchizedek, a non-Levite, as a priest of God, and the application in Hebrews of Genesis 14 and Psalm 110 to Jesus of Nazareth, another non-Levite as a priest of God, Bediako concludes: "Therefore, the priesthood, mediation and hence the salvation that Jesus Christ brings to all people everywhere belong to an entirely different category from what people may claim for their clan, family, tribal and national priests and mediators" (JAC, 28). Put slightly differently: as a "high priest according to the order of Melchizedek" (Hebrews 5:10), all of Jesus' benefits (his priesthood, mediation, and salvation) are not limited only to Jews (his tribe), but are available to all of humanity, including the Akan and other Africans. (Bediako's interest in Melchizedek and the significance of Melchizedek for him is, incidentally, in stark contrast to Barth's mere four mentions of Melchizedek — all related to Genesis 14, and none to Hebrews - in the entire

\section{Church Dogmatics.)}

Bediako's theological understanding of Jesus' universality applies to the spiritual realm that also encompasses the earthly realm. He writes, "who Jesus is in the African spiritual universe must not be separated from what he does and can do in that world. The way in which Jesus relates to the importance and function of the 'spirit fathers' or ancestors is crucial" (JAC, 22). Specifically, Jesus Christ, in the context of African ancestral understandings, is described in terms of "our Elder Brother" (JAC, 26). In turn, and more broadly, Bediako argues for Christ's "spiritual value in the religious worlds of 
other faiths...[and] his universal significance" (CFAC, 45). As "Universal Savior," Christ has spiritual value for all peoples: Africans and non-Africans, Christians and nonChristians.

Bediako's reading of Hebrews brings together his understandings of identity and history that were discussed in chapter 2 . On this point, he shares a close connection with Barth. McCormack notes how these themes (identity and history) are at play in a theological reading of the Epistle to the Hebrews. He writes:

What is true is that the writer never spells out in detail the ontology which holds the various christological elements together. His approach to treating their relationship is more indirect than direct. It lies in a focus on the identity of the subject of whom both things must be said. He narrates the identity of this subject in the form of a history - a history which begins in eternity-past and ends in eternity-future. Between these two end-points lies our history, history as we know it, the history of an individual human life which is encompassed by these end-points. ${ }^{13}$

As Bediako considers the Christological elements of Hebrews, he certainly does not limit Jesus Christ to a particular spatiotemporal locale, rather Christ is understood as a spiritual-being who is more powerful in an African cosmology than any earthly being. Even when, for Bediako, this being from before time becomes incarnate (as "the Word becomes flesh," John 1:14), the identity of Jesus Christ remains inherently spiritual— emphasizing the divine over the human. By accentuating Jesus' divinity over his humanity in order to bypass Jesus' Jewishness, Bediako's approach certainly opens up the possibility of charges of monophysitism (the belief-rejected at Chalcedon in 451that emphasized Jesus' divinity to the point of overwhelming his humanity). In my view, while Bediako's views do approach monophysitism, in the final analysis, his emphasis on

\footnotetext{
${ }^{13}$ Bruce L. McCormack, "With Loud Cries and Tears: The Humanity of the Son in the Epistle to the Hebrews" in The Epistle to the Hebrews and Christian Theology, eds. Richard Bauckham, et al (Grand Rapids: Eerdmans, 2009), 58 (37-68), McCormack's emphasis.
} 
198.

the Incarnation (as noted in chapter 2$)^{14}$ prevents him from falling into this early Church “heresy.” For Bediako, Christ's spirit existed prior to the bodily presence of Christ on earth and continued to live following Christ's ascension. The spirit of Christ never dies. A key difference between Jesus Christ and other ancestors, however, is that Christ's spirit does not continue to return to earth inhabiting, or possessing, the bodies of others. For Bediako, Jesus Christ is a unique Spirit, the Greatest of the Ancestors, the only Son of God.

His hope, more broadly than the specifics of Christology, is that the vernacular terminology for Jesus will penetrate the spirituality of African Christianity. In fact, Bediako hopes that, the vernacular, the mother-tongue, and a theology of ancestors can be blended: "In my experience in Ghana," Bediako writes, "hardly anyone will pray in English to 'Ancestor Jesus' or 'Chief Jesus,' but many will pray in Akan to 'Nana Yesu.' 'Nana' means 'ancestor' and is the title for ancestors (and chiefs)." ${ }^{\prime 15}$ The use of Nana Yesu allows for the person and message of Jesus Christ to be internalized and contextualized as an ancestor within Akan culture.

The language of prayers is just one example of how traditional African religions are not the end of a conversation about African spirituality for Bediako, but the beginning. As noted in chapter 2, African traditional religion serves as the vital "substructure" 16 for Christianity in Africa. Bediako always stresses the continuity of the Christian faith with traditional African religious beliefs, if not the specific religious practices themselves, then particularly the continuity of the human person, or human ontology. He believes that the "theological importance of such an ontological past

\footnotetext{
${ }^{14}$ See also Bediako, "Gospel and culture," 8-9.

${ }^{15}$ Bediako, "One Song in Many Tongues," in Jesus and the Gospel in Africa, 78.

${ }^{16}$ Kwame Bediako, "Thoughts on the nature of the project" JACT 11.2 (2008): 4.
} 
consists in the fact that it belongs together with the profession of the Christian faith in giving account of the same entity, namely, the history of the religious consciousness of the African Christian." ${ }^{\prime 17}$ So while, chronologically, the rites and traditions of traditional African religions are still present in Africa in ways that have remained substantially unaltered for hundreds and thousands of years, what it means to be human, or "the account of the same entity" in Bediako's language, has been irreversibly altered. The "religious consciousness" of the African Christian begins in traditional African spirituality and finds its fulfillment and completion in the Christian faith; African traditional religions are incomplete without Christ and serve in God's economy as preparation for Christianity. Through the divinity of Christ, Jesus Christ is revealed to all as the universal Savior.

\section{I.B. \\ Barth: Universality through Christ's Resurrection}

In contrast, while Barth also believes in an unbreakable relationship between God and humanity, he understands the connection as not based on the divine Christ's connection with the ancestors or with traditional cultural festivals, but on Christ's resurrection: "the living Jesus Christ risen from the dead" (IV.3, 281/324). ${ }^{18}$ Barth's understanding of the resurrection asserts the universal and the inclusive connection of Jesus Christ with all peoples, as attested in the New Testament and in Christian theology. He describes his understanding of the resurrection and its impact as follows:

\footnotetext{
${ }^{17}$ Bediako, "Understanding African Theology in the twentieth century," 51. For a more detailed analysis of Bediako's understanding of Africans' "ontological past," see chapter 2, II.C.ii, above.

${ }^{18}$ In the following excursus, Barth cites from Acts, 1 Peter, Colossians, Ephesians, and 1 Corinthians, to support his claim that "The testimony of the New Testament witnesses... is testimony to His resurrection as His self-attestation in respect of the universality, inclusiveness and continuity of His particular being and action, of its outreaching, embracing and comprehensive character" (IV.3, 281-282/325).
} 
The particular event of His resurrection is thus the primal and basic form (die Ur- und Grundgestalt) of His glory, of the outgoing and shining of His light, of the primal and basic form of His expression, of His Word as His self-expression, and therefore of His outgoing and penetration and entry into the World around and ourselves, of His prophetic work. It is to this event that the New Testament witness refers, and on this that it builds, when it speaks of the universality of the particular existence of Jesus Christ, of the inclusiveness of His specific being and action, of the continuity in which He has His own special place but reaches out from it to embrace ours too, to comprehend us men, to address and claim and treat and illumine us as His own people which we are in virtue of His being and action, and thus to find a form among us and in us (IV.3, 281 rev./324$325)$.

Here Barth connects the resurrection of Jesus Christ to the most elemental form of divine glory, the most basic expression of His Word, and the reconciling and self-revealing movement of Christ's ongoing prophetic work. Not only is the resurrection the defining moment of the New Testament— both the reason why the New Testament was written and the event to which the entire New Testament points—-but it is the resurrection that defines "the universality (Universalität) of the particular existence of Jesus Christ" (IV.3, 281/324). For Barth as for Bediako, the ongoing spiritual existence of Jesus Christ who is alive in this world goes hand-in-hand with an affirmation of Christ's universality. Through the ongoing activity of Christ as prophet, God makes Godself known. The revelation inherent in the New Testament witness to the resurrection demonstrates, further, the "inclusiveness (Inklusivität)" of the impact of the resurrection upon all humanity (IV.3, 281/324). No one is left out; no one bypassed. As Jesus Christ finds "a form among us and in us," the resurrected Christ transforms what it means to be human (IV.3, 281/324-325).

This transformation takes place as "the primal and basic form (die Ur- und Grundgestalt)" of Jesus Christ enters human existence through Christ's prophetic office 
(IV.3, 281/325-325). ${ }^{19}$ This office encapsulates "the outgoing and shining of His light" (IV.3, 281/324) that penetrates human, earthly existence. Barth is careful to hold together the incarnation and resurrection at this point in his argument. He asks, "What is specifically contributed in the resurrection of Jesus Christ as the commencement of His new coming as the One who came before, and therefore in the revelation of His reconciling being and action in its primal and basic form as the entry into His prophetic office?" (IV.3, 296/342). One reason for the question is Barth's insistence that Jesus' coming is one continuous event in many forms - that Jesus lives in diverse ways. He cites Hebrews 13:8: "Jesus Christ is the same yesterday and today and for ever" twice on the same page to emphasize his point: Jesus lives; His light can never be extinguished (IV.3, 291/336). Indeed, the living witness of Jesus Christ precedes the earthly existence of human beings and will outlast human earthly existence. (There is a striking similarity here to Bediako's claim that Christ was active in Africa before humans walked the continent.) The life, death, resurrection, and ascension of Jesus Christ are one continuous event; taken together, they are the event of reconciliation. Recall here, Barth's claim "The atonement is history (Geschichte)" (IV.1, 157/171), in the opening line of §59. Barth’s

\footnotetext{
${ }^{19}$ Barth uses the word "primal" primarily in the sense of "original" and often connects it with "basic." There are eleven uses in $\S 69$, all but one using the wording: "the primal and basic form (die Ur- und Grundgestalt)." The other use is "the primal and basic form (die Ur- und Grundgeform)" (IV.3, 294/339). Other significant uses of "primal" in the Dogmatics are the use of "first and primal (das Uralte und Erste)" when Barth is commenting on the Lord's Prayer: "This is the whole point with Jesus. His concern is not with something new but with that which is first and primal, with the God who wills to be God and to be known as God a second time in a different way, the God of Abraham, Isaac and Jacob, the God who wills to be revealed in His name and hallowed in His name." (I.1, 319/336), "primal knowledge (prima sciencia)" (I.2, §17, 289/314); "primal revelation (Uroffenbarung)" (I.2, §17, 307/335); "primal history (Urgeschichte)" of the covenant in the Exodus (II.1, \$31, 600/677); "primal decision (Urentscheidung)" (II.2, §32, 50/53). In II.2. §32, "primal" appears twenty-one times, most often in relation to Urentscheidung. II.2, §33 then contains an additional sixteen uses as "primal decision (Urentscheidung)" and "primal and basic plan (Ur- und Grundplan)." Overall, there is significant overlap between Barth's use of "primal" and Bediako's use in "primal religions" and "primal imagination." The "primal" is that which is original — going back to the earliest human ancestors, Adam and Eve — and encompasses issues of religion, and culture, in addition to revelation — as Barth uses it above in IV.3, 281/324-325.
} 
doctrine of reconciliation is based on the actual events of Christ's life.

Barth's expanded explication on the unity of Christ's reconciling and revelatory action, in $\S 69$, is worth quoting at length:

the New Testament knows of only one coming again of Jesus Christ, of only one new coming of the One who came before, of only one manifestation of His effective presence in the world corresponding to His own unity as the One who came before. This does not exclude the fact that His new coming and therefore His manifestation in effective presence in the world takes place in different forms at the different times chosen and appointed by Himself and in the different relationships which He Himself has ordained. Everything depends, of course, upon our seeing and understanding the one continuous event in all its forms. But in the time of the community and its mission after the Easter revelation it also takes place in the form of the impartation of the Holy Spirit (IV.3, 293/338).

Barth's insistence on the "one" coming and the unity of revelation echoes Barth's Trinitarian understanding of one God in three modes of being (Seinsweisen) and prevents falling into polytheism. Yet the "different forms" to which Barth refers are not Father, Son, and Holy Spirit, but instead connect back to the true words and parables of the Kingdom from IV.3, §69.2. There is one revelation of the triune God in different creaturely forms. No matter how revelation occurs, the content of that revelation is always God in Jesus Christ.

The impact of resurrection, for Barth, then, is the actualization of what has been already accomplished in Christ's life and death as well as the public revelation of these accomplishments. The high priestly and kingly work of justification and sanctification has already taken place. In the resurrection, "the alteration of the situation between God and man accomplished by Him was actualised by taking place immediately and completely in noetic form also as the prophecy of Jesus Christ by being brought out of concealment and revealed and made known to the world" (IV.3, 296-7/342). The work of 
Christ as prophet in the resurrection unveiled and declared the already accomplished work of Christ as high priest and king. At the same time, Barth refuses to allow the priestly, kingly, and prophetic work of Christ to be separated from one another. Together they are the threefold office of Christ, not three distinct offices. They are interconnected and, though distinct, are merely human linguistic and conceptual conventions for describing and attempting to understand the one work of Christ.

The death and resurrection of Jesus Christ answer the question of how, for Bediako, the universality of Jesus Christ can be understood to penetrate African culture. In agreement with 1 Corinthians, Bediako writes that "the death of Jesus...reveals death itself to be a theological problem which calls for a theological response." 20 Therefore, any theological consideration of ancestors must begin with a theological consideration of death itself and Christ's death in particular. Remembering Gyeke's claim that in the Akan universe, "What is primarily real is spiritual," 21 the central feature of Jesus' death then, is less a sacrifice than it is a triumphant and victorious return to the spirit world through Christ's resurrection and ascension. As the supreme, universal ancestor, Jesus Christ is both mediator (priest) and the ruler of the spiritual realm (chief). Since Jesus' death and resurrection have spiritual ramifications, his death affects the ancestors and the spiritual realm in which they are understood to preside. Bediako further develops this point about the interconnectedness of culture and revelation when he claims that the primal imagination is part of an African Christian's "ontological past.",22

\footnotetext{
${ }^{20}$ Bediako, "Death and the gospel," 148.

${ }^{21}$ Kwame Gyeke, Essay on African Philosophical Thought, 69. Bediako seeks to connect the death of Jesus with its impact in the spiritual world. Bediako writes, "the victory of the Cross was achieved in the realm of spiritual power, that is, in the very realm where ancestors, spirit-powers and magical forces are believed to operate." Since Jesus' death has spiritual ramifications, his death can affect the ancestors and the spiritual realm in which they are understood to preside. See Bediako, Religion, Culture and Language, 8.

${ }^{22}$ Bediako, "Understanding African Theology in the twentieth century," 51.
} 
In contrast, Barth argues that human ontology is solely to be understood in relation to God's self-revelation in Jesus Christ. Barth claims that, "Man is not a person, but he becomes one on the basis that he is loved by God and can love God in return" (II.1, 284/319, emphasis added). ${ }^{23}$ Barth's understanding of human ontology lies in human correspondence to God's loving command and differs from Bediako's view. ${ }^{24}$ Bediako makes a claim about the scope of divine revelation penetrating African religion and culture; Barth, especially after II.2, develops a full-blown theological anthropology. Particularly for Barth, Jesus Christ defines what it means to be human. Jesus Christ is the Elect One; all humanity is thereby elect in Christ. ${ }^{25}$ Bediako would insist on the ontologically-shaping role of the primal imagination in addition to Christ's defining role in shaping human identity.

For Barth, coming to a later awareness of one's election or one's identity as rooted in the being of God, does not create a period of "ontological past." This human awareness is simply coming to know what has always been the case. To express it colloquially: just because the news arrived late does not change the news (that an event previously occurred); when the event occurred is not based on when one received the news. Barth describes the situation as follows: "And in this name we may now discern the divine decision as an event in human history and therefore as the substance of all the preceding history of Israel and the hope of all the succeeding history of the Church" (II.1, 53/56-57). New information (the name of Jesus Christ, for both Barth and Bediako)

\footnotetext{
${ }^{23}$ In Barth's view, since "'God is' means 'God loves,"” the being of God as the One who loves constitutes humans as beings who receive love and give love (II.1, 283-284/318-319).

${ }^{24}$ Barth states, "Thus to know, to will, and to act like God as the One who loves in Himself and in His relationship to His creation means (in confirmation of His I-ness) to be a person. God is a person in this way, and He alone is a person in this way. He is the real person and not merely the ideal" (II.1, 285/320).

${ }^{25}$ See II.2, §33.1, “Jesus Christ, Electing and Elected.”
} 
changes how we understand the past and hope for the future. Barth's view, in sum, is that humans have always, from all eternity, been defined by Jesus Christ and only defined by Jesus Christ. Barth would therefore seek to challenge the idea that there is as an “ontological past."

Bediako might respond to Barth by claiming that it is actually knowledge, and the existential human condition, that he finds most interesting. Individuals and cultures have been shaped by what they know (or think they know) and what they believe. These forces are powerful and formative. Bediako seeks to leave some of those cultural forces in the past, while preserving and assimilating them, to allow for a present and a future shaped by Jesus Christ. The overriding question for him is: how is belief in the ancestors (as an embodiment of the past) continuous with belief in Jesus Christ? And the answer for Bediako is that Jesus himself is one of the ancestors and that Jesus has power over the entire spiritual world, including the realm of the ancestors. Christ is "the only real and true Ancestor and Source of life for all mankind, fulfilling and transcending the benefits believed to be bestowed by lineage ancestors" (JAC, 31). At this point, then, Bediako presents his own "christologized epistemology." Jesus Christ is the key to knowledge about God, humanity, the spirits, and all created things.

Is it even possible to articulate an ancestor Christology that would satisfy Barth? Bediako's inclination to start with Christ's divinity and move toward Christ's humanity can be seen as a consequence of his understanding of the Spirit of Jesus Christ. The Spirit of Christ lives in the spiritual realm giving the omnipotent and omnipresent Spirit more power to effect events on earth than would be possible for one particular Jewish man born in first-century Palestine. In contrast, Barth carefully attempts to hold together the 
divine and the human within the God-man Jesus Christ by using non-metaphysical categories, ${ }^{26}$ never losing touch with the particular Jewish individual, Jesus of Nazareth. To articulate his ancestor Christology, Bediako turned to the Epistle to the Hebrews. For his part, Barth employed Hebrews in the development of his understanding of the ongoing prophetic activity of Jesus Christ.

II.

\section{Reading the Epistle to the Hebrews Theologically}

Examining their engagement with the Epistle to the Hebrews reveals particular Christological elements in both Bediako's and Barth's theologies. As shown in chapter 2, Bediako, contrary to the instincts of many Western missionaries, believes that a theology in and of Africa is not complete without a theology of the ancestors, a theology of the dead. ${ }^{27}$ The late Cameroonian Catholic priest Jean-Marc Éla agrees; he argues that, "there is a great need to rediscover within Christianity an African vision of humanity-which is precisely what is at stake in dealing with the cult of the ancestors... [since] the deep communion established among the members of a family is not broken by death." 28 Bediako's treatment of the Epistle to the Hebrews provides an exegetical exposition of the ancestors—both African and Christian—as will be explored below, following an exposition of Barth's dogmatic reading of Hebrews.

\footnotetext{
${ }^{26}$ For an excellent exposition and application of Barth's post-metaphysical doctrine of God, see Kevin Hector, Theology Without Metaphysics: God, Language, and the Spirit of Recognition (Cambridge: Cambridge University Press, 2011).

${ }^{27}$ Bediako, "Religion and National Identity," 6.

${ }^{28}$ Jean-Marc Éla, My Faith as an African, trans. by John Pairman Brown and Susan Perry, (Maryknoll, NY: Orbis, 1988), 20.
} 


\section{II.A. \\ Barth's Dogmatic Reading}

Karl Barth's attention to the Epistle to the Hebrews, while not as extensive as his attention to other biblical works (he never wrote a commentary on Hebrews or even lectured on it) ${ }^{29}$ is nonetheless significant—particularly his use of the exordium, the opening four verses. Following Bruce McCormack's insights into Barth's practice of "theological exegesis, ${ }^{30}$ I claim that we can discern Barth's understanding from his forty-two citations of Hebrews 1:1-4 in the Church Dogmatics. ${ }^{31}$ McCormack understands Barth's practice of theological exegesis to be a different type of reading than practiced by many historical-critical scholars of the New Testament. He describes Barth's method as follows: "The task of the theologian is not simply to ask what the author of Hebrews said but to ask what the New Testament (and the Bible as a whole) have to say—a task which requires us to read across documents in a synthetic fashion." ${ }^{32}$ This approach leaves Barth relatively uninterested in questions of authorial intent or readerresponse criticism. His practice is a narrative exegesis - treating the parts of a text as part of a larger whole- yet his focus is not on an individual book but on the whole of the Biblical witness.

Barth frequently cited and commented on the Epistle to the Hebrews throughout

\footnotetext{
${ }^{29}$ Barth had planned to lecture on Hebrews during the summer semester of 1922 at the University of Göttingen, but found that his main lecture course on Calvin was too demanding so canceled his plan to teach Hebrews. See Bruce L. McCormack, "The Identity of the Son: Karl Barth's Exegesis of Hebrews 1.14 (and similar passages)" in Christology, Hermeneutics, and Hebrews: Profiles from the History of Interpretation (London: T\&T Clark, 2012), 155.

${ }^{30}$ Bruce L. McCormack, "The Significance of Karl Barth's Theological Exegesis of Philippians” in Karl Barth, The Epistle to the Philippians: $40^{\text {th }}$ Anniversary Edition (Louisville: Westminster John Knox Press, 2002), v-xxv.

${ }^{31}$ See 1:1, six uses: (I.2, 84; III.1, 115; III.2, 462; IV.3, 93; and IV.3, 584); 1:2, twelve uses: (I.2, 401, x2; 442; I.2, 148; II.1, 416; II.2, 99; III.1, 19, 51, 53; III.2, 483; IV.2, 34; IV.3, 93); 1:3, twenty-one uses: (I.1, 360, 386, 429; I.2, 379; II.1, 416, 606, 661; II.2, 99, x2; III.1, 54; III.2, 466; III.3, 10, 35, 59, 439, x2; 441; IV.1, 44; IV.3, 195, 767); and 1:4, three uses: (I.2, 379; III.2, 14; III.3, 453).

${ }^{32}$ McCormack, "The Identity of the Son," 156 , McCormack's emphasis.
} 
his Church Dogmatics. Confining our analysis to IV.3, §69, Barth employed Hebrews to present Christ as a witness and apostle (IV.3, 12/12) who as one and the same person proclaimed his work as high priest (IV.3, 13/13) that destroyed (IV.3, 169/193) and overcame evil and death (IV.3, 238/272). In Hebrews, Barth finds justification for identifying Christ as prophet within the structure of the Biblical witness-whose power upholds all things as the one Word of God (IV.3, 195/223). Hebrews underlines Barth's claims about the sole revelation of God in Jesus Christ as prophet (Hebrews 1) and the sole reconciliation of Christ as priest (Hebrews 10). And, as mentioned in the previous section, Barth appeals to Hebrews 13:8 to demonstrate that as Jesus Christ lives, both light and revelation are ongoing.

As will be explored in more detail below through the examination of Hebrews and revelation, Barth connected the Christological expressions in the exordium of Hebrews with the prologue to the Gospel of John and discerned a shared focus in these two books on the divine of the God-man over the human. This scriptural connection undergirds Barth's belief in the movement of revelation from God to humanity and human cultures. God's self-revelation originates within Godself and radiates outward enlightening the world and enkindling human understanding of God through the work of Christ on behalf of humanity. Barth harvests insights from Hebrews-particularly about Christ as prophet and priest — that he applies dogmatically in a coherent and systematic approach to Christology.

\section{II.B.}

\section{Bediako's Cultural Reading}

Bediako took a different tack by focusing in on the cultural relevance of Hebrews 
to Africans, yet he also made use of Hebrews' descriptions of Jesus' divinity. He claims the Epistle to the Hebrews for all Africans, referring to it as: "OUR Epistle!" (JAC, 27). ${ }^{33}$ In "Jesus in African Culture," Bediako explores the themes of sacrifice, priestly mediation, and ancestral function in his exposition of Hebrews.

Bediako used Hebrews not only to connect Jesus Christ to the ancestors but also to the traditional Akan festival of purification, reconciliation and renewal, Odwira, that marks the end of one year and the start of the next (CiA, 71). In 1990, at the Odwira Thanksgiving non-denominational service to mark the end of the week-long Odwira festival in Akropong-Akuapem, Ghana, Bediako preached a sermon, "Christ, Our Odwira" based on two texts from Hebrews, 1:1-5 and 10:1-10. Bediako asserted the connection between Hebrews and Odwira in the first line of the sermon: "It may seem to some person that culture and tradition have nothing to do whatsoever with Christ. And yet, our Scripture reading from Hebrews shows us that our present great festival of Odwira is itself mentioned in the Bible." ${ }^{34}$ His provocative claim that "Odwira is itself mentioned in the Bible," is obviously not intended literally. The claim is based on the use of the Twi verb, dwiraa, in the vernacular translation of Hebrews 1:3, translated in English variously as purgation, forgiveness, or purification —as in "When he had made purification for sins" (CiA, 70-72). This verb is also the root of the name of the festival,

\footnotetext{
${ }^{33}$ Bediako's views on the Epistle to the Hebrews are most clearly expressed in three published works: 1."Jesus in African culture: A Ghanaian perspective," first published in 1990. This original pamphlet was republished in Jesus and the Gospel in Africa from which the citations here are taken; abbreviated as JAC.

2. Christianity in Africa, Chapter 12: "Christian Religion and the African World-view: Will Ancestors Survive?", 210-234; abbreviated as CiA.

3. The posthumously published article, "Christian Faith and African Culture-An Exposition of the Epistle to the Hebrews," JACT 13:1 (June 2010), 45-57; abbreviated as CFAC.

There are also a number of helpful unpublished sermons on Hebrews held in personal archive of Bediako's widow, Dr. Gillian Mary Bediako.

${ }^{34}$ Kwame Bediako, "Christ, Our Odwira," sermon preached on $30^{\text {th }}$ September 1990 (and again on 22 October 1995), on Odwira Sunday, Mpeiase, Akropong, 1. In the personal collection of sermons on the Epistle to the Hebrews of Gillian Mary Bediako in Akropong-Akuapem, Ghana.
} 
Odwira. The local Akan chief Oseadeeyo Addo Dankwa III defined Odwira as "the period of purification. As human beings, we have, over the past years, committed a lot of mistakes and as we enter this period of purification, we should ponder over our past mistakes and resolve to improve upon our behavior." ${ }^{, 35}$ Significant here is the admission of wrong-doing and the possibility of future correction as connected to a time to pause, reflect, and steel oneself for future challenges through "this period of purification," that is, some type of cleansing. Through a Christian lens, one sees elements of confession, but not forgiveness; there is future resolve, but without the sanctifying power of the Holy Spirit.

A local Bible study Bediako led in Akropong was the source of his connection of Odwira to Hebrews. The group had been studying the Epistle to the Hebrews in Twi when "it seemed to have occurred to our group members that Odwira had something to do with Jesus, and that the atoning work of Jesus could be related to the traditional Odwira rituals and its anticipated benefits" (CiA, 71). For Bediako, the significance of this realization could not be overstated and informs his interpretation of Jesus as Ancestor. He writes, "The vernacular scriptures became the means of gaining a further insight into the traditional culture, whilst the meaning of the Scriptures was also illuminated in a new way, in relation to a vital aspect of the traditional culture" (CiA, 71). This example demonstrates the interplay for Bediako between the Bible and elements of African culture. While reading Hebrews in Twi, the connection of Jesus' work, making "purification for sins" (1:3), to the purification sought in the Odwira festival, was readily apparent linguistically. Through the use of the mother-tongue, a connection between

\footnotetext{
35 "Speech by Oseadeeyo Addo Dankwa III, Okuapehene on the occasion of the 1990 Odwira Durbar," at Akropong-Akuapem on Friday $28^{\text {th }}$ September 1990, page 1. In the personal collection of sermons on the Epistle to the Hebrews of Gillian Mary Bediako in Akropong-Akuapem, Ghana.
} 
Christ and culture was drawn. No longer could Christ's purification and Odwira be considered separately; now, by reading "ode n'ankasa ne ho dwiraa yen bone no" (Hebrews 1:3), the connection between Christ's purification and the Odwira festival is unavoidable. ${ }^{36}$ Not only did the Twi translation allow for a connection to be made between the Bible and Akan culture, this connection also had theological import for Bediako. Because the linguistic connection existed (i.e. that both Christ and Akan culture present a way to offer purification) Bediako claimed theologically that this connection demonstrated God's providential provision. He used the Bible study group's conclusion to express his theological methodology and underlying conviction: "Christ had a stake in the spiritual universe of traditional religion" (CiA, 72). Bediako's conclusion connects his reading of Hebrews to the means of God's revelation through a traditional festival.

\section{II.C. \\ Hebrews and Revelation}

Each theologian's overall understanding of and approach to revelation can be demonstrated through an examination of how he reads the Epistle to the Hebrews. In $\S 69.2$, Barth explores Hebrews 1:1-4 as he considers the meaning of Jesus Christ as "The Light of Life" and the reality of ongoing revelation. He uses the opening verses of Hebrews to demonstrate that the author of the Epistle does not anticipate any materially new revelations after the ascension of Jesus Christ. Barth writes that, "the circle of Old Testament expectation and New Testament recollection is for the author of the Epistle a closed one outside of which there cannot be considered, nor is there to be expected, any

\footnotetext{
${ }^{36}$ For more on the connection between the Odwira festival and the Christian faith, see Frank Kwesi Adams, Odwira and the Gospel: A Study of the Asante Odwira Festival and Its Significance for Christianity in Ghana (Oxford: Regnum, 2010).
} 
other speaking on the part of God" (IV.3, 94/104). Bediako as well, notes in Hebrews 1:1 “the use of the past tense-'he spoke' (Twi: skasa kyerec yen), indicating that God's speaking is complete" (CFAC, 47). However, Bediako goes further than Barth in expressing that

the text does not itself make this limitation [of God's past speaking] to Jewish ancestors. It states quite simply: 'God spoke to the fathers.' The Twi here is more accurate: 'kasa kyerce agyanom.' There is a point to the text using the absolute term, 'the fathers,' rather than the interpreted and specific 'our fathers.' For the text thus leads to the recognition that the universal relevance of the revelation in Christ applies equally to the revelation given in the former times (CFAC, 47).

Bediako's point is that God has spoken to all peoples "in all contexts...in the One who is a Son" (CFAC, 47). Further, since the content of God's speaking is "not a secret," we know that God spoke differently — though consistently and through Jesus Christ - to the Israelites than to Jewish Christians in the first century. A God who could speak differently in one context than that same God had spoken previously — in a separate context— can and does continue to speak today: differently in different contexts. The hermeneutical move made by the author of the Hebrews to construct a Christology as a Jewish Christian is precisely the move Bediako makes himself. ${ }^{37}$ He intentionally seeks to construct his Christology as an African Christian.

Barth agrees with the author of the Epistle that revelation is complete (though he would add, unfinished and ongoing) in the life, death, resurrection, and ascension of Jesus Christ, but he also claims that Jesus continues to reveal who God is - not necessarily new aspects or attributes of who God is, but reveals the same being of God in new ways to changing cultural contexts. Barth quotes additional scriptural texts to

\footnotetext{
${ }^{37}$ The questions surrounding the authorship of the Epistle to Hebrews are unresolved. Though many had long assumed that Paul had written the letter, the current scholarly consensus opposes that view, but does stress that the author was a Hellenistic Jew.
} 
demonstrate that God's work on earth is not finished and that Christ as Prophet continues to reveal who God is in ways that the author of the Epistle never imagined (IV.3, 94/104). Bediako's reasoning on this point is not as nuanced. He continues to claim that all revelation is in and through Jesus Christ. Christ continues to work through cultural forms, including traditional African religions, but these ongoing revelations are partial and incomplete. Only the revelation of God in Jesus Christ as conveyed in the scriptures of the Old and New Testaments is the full and complete revelation of God in Jesus Christ. As will be explained more fully in the final section of this chapter, the main difference between Bediako and Barth regarding the ongoing nature of revelation is that Bediako posits a perpetual relationship between ATR and revelation while Barth insists that revelation extra muros ecclesiae (outside the walls of the Church) is only occasional, or ad hoc. For Barth, Christ's revelatory presence does not remain within cultural media indefinitely.

Regarding the understanding of revelation articulated in the opening verses of the Epistle to the Hebrews, this comparison demonstrates that Bediako's views more closely adhere to the plain sense of the Exordium read on its own terms than do Barth's. Barth reads Hebrews 1 through the lens of John 1. McCormack describes the connections that Barth saw: "the high Christology of the Johannine prologue does indeed find a parallel in the exordium. But it must also be conceded that Barth found in John 1 a key to the gradual unfolding of a Christology which would eventually become a material key for understanding his exegetical work even on Hebrews 1:1-4."38 Barth's expansive understanding of Christ as prophet allows for, and truly mandates, the real revelation of who God is through Jesus Christ by the Holy Spirit in and through contemporary human

\footnotetext{
${ }^{38}$ McCormack, "The Identity of the Son,” 156.
} 
cultures in true words and parables of the kingdom, in ways that the author of the Epistle never could have imagined. In an excursus, Barth appeals to Mark 10:17ff., Mark 2:5ff., 1 Corinthians 8:6ff., 1 Timothy 2:5, and Romans 3:29ff., to distinguish the one God as "the Word spoken in the existence of Jesus Christ from all others as the Word of God" (IV.3, 99/110). Bediako does not explore Christologically the notion of prophet that Barth offers. Bediako is much more interested in Jesus' mediatory role between God and humanity (as priest). In fact, for Bediako "the gospel"- understood in the sense of the totality of Christ's saving work - does much of the work that Barth attributes to Christ as Prophet. Whereas Bediako elucidates, the "infinite translatability of the gospel," Barth speaks of Jesus' prophecy as the Light of Life and seeks to hold together Christ's threefold office — as priest, king, and prophet.

For Barth, the sole revelation of God in Jesus Christ (as expressed in the exordium of the Epistle to the Hebrews) is inextricably connected to the sole reconciliation in Jesus Christ (expressed as sacrifice and offering in Hebrews 10). The uniqueness of Christ's prophecy, witness, and proclamation is thus tied to Hebrews 10:12 and 10:14 that "speaks of the one exclusive $\theta v \sigma i ́ \alpha$ (sacrifice) or $\pi \rho о \sigma \varphi о \rho \tilde{\alpha}$ (offering) which Christ has made for sins, which is followed by His session at the right hand of God, but by which He has perfected forever them that are sanctified through Him" (IV.3, 110/122). Jesus is the sole Mediator of both revelation and reconciliation. Indeed, in Christ, reconciliation is revelation! Barth then does not allow Christ to be confined to one historical epoch or the pages of a human book (the Bible); Christ the Prophet continues to speak "good words...extra muros ecclesiae (outside the walls of the church)" (IV.3, $110 / 122)$, if and when God so chooses. 
"God spoke to our ancestors" (Hebrews 1:1), "God has spoken to us by a Son" (Hebrews 1:2), and God continues to speak, as Barth expresses it: "words of genuine prophecy...that meet and match with the one Word of God Himself and therefore with that of His one Prophet Jesus Christ" (IV.3, 111 rev./122). In spite of the completeness of the self-revelation of God in Jesus Christ through the witness of the Bible, through the “universal prophecy of Jesus Christ" (IV.3, 129/145), God can choose to reveal who God is in distinct and novel ways through contemporary forms. While affirming God's selfrevelation outside of the Bible or the Church, Barth is also preserving a kind of occasionalism. The chosen medium — whether a religion, a sunset, or a farmer sowing seeds - does not possess God's self-revelation. Instead, the medium is a conduit for the light of Christ's prophetic activity that shines on Christ's reconciling life. Revelation itself is an act of God. Revelation does not exist in a vacuum apart from Christ's ongoing prophetic activity.

While Bediako would affirm God's ongoing activity, his understanding of revelation is more static and less dynamic than Barth's. In many ways, Bediako's project is a continual process of trying to understand and appropriate the God who has been revealed in Jesus Christ in light of African culture. He is continually seeking to strip away Western interpretations of the scriptures of the Old and New Testaments to get a better grasp of the revelation of God that has already occurred—without looking for additional sources of revelation in contemporary cultural forms - while also binding the gospel to ATR. In this way, Bediako is seeking to separate Jesus Christ and the gospel from Christianity as a Western religion and is consistent with the evangelical heritage of his early theological education — a heritage that generally regarded Barth's ideas on 
revelation with significant skepticism.

Bediako sees tremendous possibilities in reading the Epistle to the Hebrews today: "It seems to be that the new African theology will have to attempt what the writer of the Epistle to the Hebrews did: that is, to make room, within an inherited body of tradition, for new ideas, for new realities which, though seemingly entering from the outside, come in to fulfill aspirations within the tradition, and then to alter quite significantly the basis of self-understanding within that tradition" (CiA, 84). Bediako sees Hebrews as a way of reading the presence of Jesus Christ in African culture from the inside out. His starting point is within African culture and seeks to understand and appropriate revelation from within culture. Bediako describes his method in one of his earliest publications: "My own approach is to read the Scriptures with Akan traditional piety well in view. In this way, we can arrive at a Christology that deals with the perceived reality of the ancestors, I also make the biblical assumption that Jesus Christ is

not a stranger to our heritage. ${ }^{39}$ On the other hand, Barth begins with an understanding of God's self-revelation that cannot be separated from the unique person of Jesus Christ. For him, revelation begins outside culture and penetrates culture through Christ's ongoing prophetic activity. These differences in their understandings and appropriations of revelation are closely related to their Christocentric theological positions. The revelation of God is ongoing in and through the forms of material culture.

\section{III.} Encounters between Gospel and Culture

All encounters between gospel and culture must occur in a place. Bediako and

\footnotetext{
${ }^{39}$ Bediako, "Biblical Christologies," 100-101; see the same text, slightly edited, in JAC, 24.
} 
Barth are cognizant of the very particular cultural details in every engagement between the gospel and culture. This engagement is captured in Eugene Peterson's paraphrase of John 1:14: "The Word became flesh and blood, and moved into the neighborhood." 40 The inhabitants of a place develop their self-understanding of culture and identity within that place. ${ }^{41}$ The questions asked and the theological responses given are inextricably linked to the site of each particular encounter between gospel and culture. The interaction between place, culture, language, identity, faith, and theology is also full of possibility (and some would say peril). In these encounters, issues of revelation, religion, and culture become intertwined and not easily separated. The remainder of this chapter will address these three themes - first individually though a comparative lens and then collectively.

\section{A.}

\section{Revelation: Translatability and Light}

For both authors, the name of Jesus Christ identifies the second person of the Trinity, the Son of God incarnate. Both authors appeal, as has been shown, to the prologue to the Gospel of John as a starting point for their theological reflections about the activity of God in the world. Many of the themes of interest to Bediako and Barth appear in the first four verses: time, the relationship between God and the Word, the process of creation; and the connection between Jesus Christ, life, light, and all people. For Bediako, verse 14 serves as the basis for his understanding of the infinite translatability of the gospel of Jesus Christ: that the Word (ó $\lambda$ ó $\gamma \circ \varsigma)$ "became and dwelt"

\footnotetext{
${ }^{40}$ Eugene H. Peterson, The Message: The Bible in Contemporary Language (Colorado Springs, Colorado: NavPress, 2005), 1441.

${ }^{41}$ For an insightful treatment of the role of place in theological and personal self-understanding see: Mary McClintock Fulkerson, Places of Redemption: Theology for a Worldly Church (Oxford: Oxford University Press, 2007).
} 


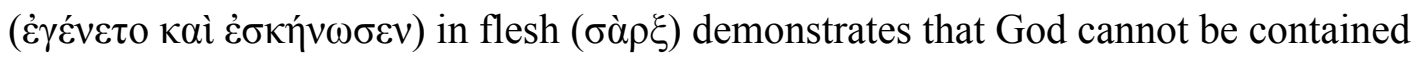
within the spiritual realm but decisively entered into the human, earthly realm. This transcendent boundary-crossing that took place continues throughout recorded time and history in the continual engagement of the gospel and culture.

For Barth, the significance of verse 14 has already been discussed above. The more interesting verse, at least for the sake of this comparison, lies earlier in John's prologue, when Barth connects the Word (ó $\lambda$ ó $\gamma \circ$ s) and the words (ó $\lambda$ ó $\gamma o i)$ from John 1:4. ${ }^{42}$ Very early in $\S 69$, Barth used this verse to connect the major themes of $\S 69$ (IV.3, 9/7). Note Barth's emphases in concluding his one-page excursus on the verse: "What is said in Jn. $1^{4 f .}$ is that this life in its determination as light, reconciliation in its character as revelation, is outgoing and self-communicative, so that, as it has taken place in the world, it breaks out and goes into the whole world, to every man (v. 9)" (IV.3, 9/8). The concepts that Barth draws from John 1:4—life, light, reconciliation, and revelation—fill his exposition of the third problem in the doctrine of reconciliation, Christ as Prophet, understood as the "Glory of the Mediator" and of his articulation of Jesus Christ as the Light of Life in particular. The ongoing prophetic activity of Jesus Christ brings life to all people by indiscriminately shining the light of reconciliation that reveals who God is.

If Bediako's driving question is: "What happened when God-in-the-flesh moved into the neighborhood of Africa?," how would Barth answer this same question? For Bediako, "what happened?" unfolds in two steps. First, God has always been in Africa and did not need to "move-in" after Africans already lived there. The identity of God-inthe-flesh, Jesus Christ, was "hidden" in sub-Saharan Africa prior to the arrival of the European missionaries. In these years, God was at work among God's (African) people,

${ }^{42}$ See Greggs, Theology Against Religion, 91. 
incompletely and imperfectly revealing aspects of who God is through African traditional religions and African culture. Second, as Europeans introduced the name of Jesus Christ to Africans and, more importantly, first translated the texts of the Old and New Testaments into African mother-tongues, so too African Christians have been seeking to translate the words, images, and concepts of the Bible into African terms and idioms. This process is ongoing as African realities change and Africans seek to better understand and appropriate the gospel of Jesus Christ.

Barth might reject the image of Christ coming to Africa as distinct from Christ coming to humanity as a whole. In God's "primal decision” to be a God-for-others, God chose for the second person of the Trinity to become a human being as Jesus Christ. Indeed, Jesus Christ is the true human, in whose image all other humans have been created. Humans who happened to live on the continent of Africa are therefore understood to be made in the image of God and God has been present among them in ways that are hidden and veiled. One can also say, in light of IV.3, that God's sovereignty supports the claim that God could use any and all cultural forms to reveal who God is. Yet, in spite of the multitude of ways that God might be working, true knowledge of and relationship with God is only possible in Jesus Christ. And Barth is certainly not going to displace Judaism with ATR as evangelico preparatio. (Granting the important debates about Barth and supersessionism, ${ }^{43}$ it can be affirmed that Barth sees an important and unique place for Israel and the Jews in his theology; a comparable affirmation cannot be

\footnotetext{
${ }^{43}$ Questions surrounding Barth and the Jews are hotly debated. For two valuable views see: Katherine Sonderegger, That Jesus Christ Was Born a Jew: Karl Barth's “doctrine of Israel” (University Park, PA: Pennsylvania State University Press, 1992), Mark R. Lindsay, Barth, Israel, and Jesus: Karl Barth's Theology of Israel (Barth Studies Series; Aldershot: Ashgate, 2007), and Mark R. Lindsay, Reading Auschwitz with Barth: The Holocaust as Problem and Promise for Barthian Theology (Eugene, OR: Pickwick, 2014).
} 
made about Bediako.) Barth would believe that the rays of Christ's light, the light of life, would shine on all Africans seeking to draw all people to live in correspondence to the command of God.

The shining of this "eloquent and radiant" light through "true words" and "parables of the kingdom," is a result of Christ's ongoing prophetic activity. The shining of this light is similar to Bediako's understanding of translatability, but Barth stresses the outgoing movement of Jesus Christ, the light of life, more than the human reception of the gospel in the encounter of the gospel with culture. Certainly, Bediako bases his understanding of translatability on the "first translation" of God into human flesh. But much of the rest of his work on translatability focuses on humans continuing, or mimicking, the work of that first translation, not on how God continues to "translate" Godself. A linguistic hint of this difference lies in Bediako's consistent use of "the gospel" (not Jesus Christ) as the object of translation, as in "the infinite translatability of the gospel." Barth does not allow this translation of God to take place apart from God's eternal divine decision, God's communicative and revelatory action, and God's occasional uses of parables of the Kingdom and true words. Again, God always uses creaturely media; what is "occasional" is God's use of media that are not scripture and preaching.

In a sense, the difference between Bediako and Barth on translatability rests on two interpretive decisions. First, in exegeting John 1, what is meant by two phrases: "In the beginning" (v.1) and then "the Word became flesh" (v.14)? Is there a temporal gap between verses 1 and 14? Bediako seems to say yes, while Barth says no. For Barth, the 
second person of the Trinity is always and forever Jesus Christ, the incarnate one; ${ }^{44}$ Bediako offers no such specificity. Second, Barth chooses to emphasize the being and movement of God at all times, prior to human action. Bediako resists any deemphasizing of human agency in translation, particularly because of how many Christian missionaries' attempts to translate the gospel have had detrimental effects on Africans and African culture. These differences manifest themselves in interesting ways as Bediako and Barth engage questions of religious pluralism — a context that Bediako lived amidst and with which he was very familiar and one that Barth treated more theoretically. Next, the topic of "religion" - a frequent topic in both their writings and an area where both had extensive experiences_-will be explored.

\section{III.B.}

\section{Religion: An Unexpected Convergence}

The engagement of Bediako and Barth on the category of religion produces one of the unexpected convergences between their thought: both authors criticize religion as projection. Above we explored Bediako's understanding of the power of ancestors within traditional African religions as "myth." Bediako believes that the ancestors do not have any real power or direct influence in the world. Their only power is the power of mythmany Africans believe that the ancestors have power and act accordingly. Indeed, for Bediako, the entire cult of ancestors is a myth — albeit a very significant myth in the lives of Africans. Bediako's point of view is shared by most African Christians, but rejected by practioners of traditional African religions. ${ }^{45}$ One of the primary distinctions separating

\footnotetext{
${ }^{44}$ See Michael T. Dempsey, ed. Trinity and Election in Contemporary Theology (Grand Rapids: Eerdmans, 2011) for a collection of essays debating this point within Barth studies.

${ }^{45}$ See Anthony Ephirim-Donkor, African Religion Defined: A Systematic Study of Ancestor Worship among the Akan (New York: University Press of America, 2010), Anthony Ephirim-Donkor, African Spirituality:
} 
Christians from non-Christians in Africa is this question of whether or not the ancestors have power. If an individual or community believes that the ancestors do have power then, for many, they cannot be Christian. And this distinction is what enables some Christians to label African Independent, or Initiated, Churches (AICs) as syncretistic. The logic runs as follows: while incorporating many Christian elements, since AICs believe in the power of ancestors and venerate them, AICs cannot be Christian, because the ten commandments state that there should be no other gods other than God in Jesus Christ.

Questions have been posed to Bediako about his ancestor Christology in light of his claim that the ancestors do not have power. First, following Agyarko's criticism (articulated in chapter 2), if the ancestors do not have power then why would Bediako want Jesus as the all-powerful incarnate son of God to be a powerless ancestor? Second, if the ancestors are powerless, because they are dead, even if they are understood as the living dead - they are still dead — then why would Bediako want the resurrected and ascended Jesus Christ, who is alive, sitting at the right hand of the Father, to be a dead, powerless ancestor? The suggestion of these critics is to leave the ancestors alone (i.e. ignore them) — since they are merely part of the myth of ATR — and to preserve Jesus' uniqueness. There is no need to force Jesus to be an African ancestor.

Yet Bediako simply cannot leave the ancestors alone. In my view, there are two reasons for Bediako's ancestor Christology both of which derive from his understanding of culture. First, if African traditional religion (ATR) is preparatio evangelico, there must be seeds of Christianity within ATR. By working backwards, Bediako demonstrates the seeds of Christianity by identifying the "fruit": Jesus as Ancestor. Second, if the gospel of 
Jesus Christ can be translated into any culture, then the gospel must have something to say about the cult of the ancestors. Ephirim-Donkor makes the point that ancestor veneration is at the heart of ATR. ${ }^{46}$ As such, Bediako wants to demonstrate the relevance of Jesus Christ to the most central belief of ATR. Bediako's understanding of ATR as "a myth" is therefore part and parcel with his belief that ATR is a shadow of the full revelation of God in Jesus Christ. The traditions and practices of ATR point to truths about who God is, but only partially and incompletely.

As was discussed in the previous section, Bediako's understanding of ATR is not all that different from many Western Christian understandings of the incompleteness of Judaism. ${ }^{47}$ Bediako clearly and explicitly states that ATR is fulfilled with the name of Christ and the Christian Scriptures. He also repeatedly asserts that Western Christianity is a religion that is actually a flawed worldview, a distortion of the true Christian faith.

After all, "It is not Christianity that saves, but Christ" (TI, 244). On this point, Bediako follows the fairly typical evangelical Protestant perspective that Christianity is a relationship, not a religion. ${ }^{48}$ What then does this mean for African Christianity? According to Bediako in the subtitle to his second book, Christianity in Africa is the renewal of a non-western religion. Bediako sees positive possibilities for religion once it is stripped of its cultural baggage. He walks a fine line as he seeks to peel away the layers of false cultural interpretation placed on the Christian faith while simultaneously affirming that Christianity must be translated into cultural forms. Indeed, it often appears

\footnotetext{
${ }^{46}$ Ephirim-Donkor, African Religion Defined, v.

${ }^{47}$ This strain of thought can be traced back to Augustine (see De civitate Dei, 4.34, 18.46) and is addressed by Barth in II.2, §34- "The Election of the Community."

${ }^{48}$ Among others, Billy Graham encapsulated this viewpoint when he wrote: "[Consider] the novel thought that Christianity was not so much a "religion" as a relationship with a Person" in Billy Graham, The Jesus Generation (London: Hodder and Stoughton, 1972), 148.
} 
that, for Bediako, no form of the Christian faith in the Western world can be sufficiently separated from Western culture to be authentically Christian. But if there is no such thing as a pure Christianity and the Christian faith must take cultural forms, then how can "relevance without syncretism" (CiA, 85$)$ be achieved? Before addressing this question in the next section, Barth's views on religion as projection will be explored.

Barth, as noted in chapter 3, adapts Feuerbach's critique of religion as projection. Barth does not understand the Christian religion, or even any Christian rituals to contain or offer any divine power. In religious rituals, and in religion more generally, Barth is seeking the person of Jesus Christ behind the human projections. As was shown in my exposition of I.2, §17.3, "The True Religion," Barth does believe that Christianity can be the true religion, if Christians worship the one true God in Jesus Christ. On this reckoning, no non-Christian religion can be true, although other religious traditions may have truth in them. ${ }^{49}$

For both authors, the name of Jesus Christ is of the utmost importance. In I.2, $\S 17.3$, Barth insists that the name of Jesus Christ that sets Christianity apart from all the other religions of the world as the true religion. Barth then fills out the meaning of the name throughout the rest of the Dogmatics, particularly in volume IV. Intriguingly, for Bediako the name of Jesus Christ is one of the two things that the European missionaries brought to Africa that Africans did not have (the other is the Bible). For both authors, there is something about that name that is important and significant that uniquely distinguishes the Christian faith from other religious traditions. As will be discussed below, Bediako and Barth differ on how they understand the specifics of Christ's-

\footnotetext{
${ }^{49}$ See the discussion of grace in Pure Land Buddhism in I.2, §17.3, 340ff. $/ 372 \mathrm{ff}$.; and the parables of the kingdom in $§ 69.2$.
} 
indisputably central role - in salvation because of their disparate understandings of universal revelation and universal reconciliation.

\section{C.}

\section{Culture: Differing Universalisms}

Discussing the topic of universalism under the heading of "Culture" appears to be a category mistake until one considers that Bediako treats African culture as universal revelation to all Africans. In this way, Bediako begins with universal revelation through African culture that is true, though partial, revelation and then adds the name of Jesus Christ and the Christian scriptures. This completed, full revelation informs Africans of God in Jesus Christ with whom they are already in relationship. The atoning work of Christ makes possible this continuing relationship. In Bediako's work, the concept of reconciliation is rarely treated, and when it is, it often refers to reconciling ethnic groups or philosophical ideas, not the divine human relationship. In contrast, Barth titled the fourth volume of his Church Dogmatics (of which IV.3 is one part-volume), "The Doctrine of Reconciliation.”

Both Bediako and Barth are unapologetically Christocentric and neither is certain that human beings are eternally saved regardless of their actions on earth. Both would reject the appellation of "universalist," while also hoping that all people may be saved. Barth would disagree with the moniker because universalism is a principle that departs from the actual history of Jesus Christ, and because he does not see sufficient Biblical evidence to prove that all humanity is saved in Christ. ${ }^{50}$ Instead, Barth sees a clear hope that it is so. Bediako's understanding of evangelical Christianity requires him to insist on

\footnotetext{
${ }^{50}$ For more on Barth and universalism see, Tom Greggs, “'Jesus is victor': passing the impasse of Barth on universalism” Scottish Journal of Theology 60:2 (May 2007): 196-212.
} 
a personal response to the gospel as ingredient in personal salvation. Nearly all of his sermons conclude with call for a response from the listeners. (In Gillian Mary Bediako's collection of his sermons, there is a whole grouping labeled, "revivals/evangelistic.") And as Kwabena Asamoah-Gyadu remarked in the first Kwame Bediako Memorial lecture, "he is the only African evangelical theologian and preacher that I have personally witnessed calling for people to physically come forward to offer their lives to Jesus Christ in a Billy Graham-style Altar Call." ${ }^{, 51}$ Yet since Bediako did not think of himself in the categories of Western thinkers like John Calvin, Jacobus Arminius, and John Wesley, and he did not articulate a formal doctrine of atonement, it is difficult to label Bediako's stance on how a person is saved. Even without a classification, Bediako does provide enough material with which to describe his understanding. Bediako’s understanding of salvation attempts to combine the cosmology of ATR with an evangelical emphasis on a personal response to the gospel of Jesus Christ.

Bediako does believe that the Christian faith has been universally revealed by God to all, including Africans, at first through African traditional religions and then later through Christian churches by Africans and Europeans alike. He also nowhere advocates a version of "universal reconciliation" that Barth promotes. This omission comes, in no small part, from the general lack in Bediako's work of discussions of personal sin. In his most sustained treatment of sin, Bediako writes,

In our [African] tradition, the essence of sin is in its being as an antisocial act. This makes sin basically injury to the interests of another person and damage to the collective life of the group.... [Yet] Sin is more than antisocial act; the sinner sins ultimately against a personal God with a will and purpose in human history (JAC, 26).

\footnotetext{
${ }^{51}$ Kwabena Asamoah-Gyadu, “ "Who do you say that I am?: Revisiting Kwame Bediako's responses to an eternal Christological question," Kwame Bediako Memorial Lecture, July 7, 2009, (British Council Hall, Accra, Ghana), 11.
} 
Without an emphasis on sin (particularly on sins by individuals), Bediako does not seek the same "universal reconciliation" that Barth offers. Bediako's understanding of sin is consistent with other African Christians who view salvation as a "holistic experience... [of] total well-being," ${ }^{, 52}$ that "embrac[es] both the physical and the spiritual,"53 and addresses "physical and immediate dangers that threaten individual or community survival, good health and general prosperity or safety...Salvation is not just an abstraction, it is concrete. ${ }^{, 54}$ Consistently with an African cosmology, Bediako's understanding of the Christian faith seeks access to God without needing to overcome separation from God. Yet, for Bediako, the universal revelation calls for an individual, personal response. Without this individual response, salvation is not possible. In contrast to both Barth's belief in the universal reconciliation of all humanity and his hope that all are already saved in Jesus Christ and also to the traditional African understanding that God has fully revealed who God is in and through traditional African religions in such a way that demonstrates God's universal presence among, with, and within African peoples and African cultures, Bediako asserts universal revelation, but not universal reconciliation or salvation. (Barth presents universal revelation through universal reconciliation.)

To better understand Bediako's appropriation of universal revelation within ATR, a comparison with fellow Ghanaian (and Akan) Kofi Asare Opoku is helpful. Opoku

\footnotetext{
${ }^{52}$ Cyril Okorocha, "The Meaning of Salvation: An African Perspective" in Emerging Voices in Global Christian Theology, ed. William Dyrness, (Grand Rapids: Zondervan, 1994), 76.

${ }^{53}$ John Mbiti, Bible and Theology in African Christianity (Nairobi: Oxford University Press, 1986), 158159.

${ }^{54}$ John Mbiti, "Some Reflections on African Experience of Salvation Today," in Living Faith and Ultimate Goals, ed. S.J. Samartha (Geneva: World Council of Churches, 1974), 112-113. See also Kofi Opoku, "Toward a Holistic View of Salvation" in Healing for God's World: Remedies from Three continents (New York: Friendship Press, 1991), 41-60.
} 
interprets traditional African religions to present an understanding of universal revelation within that he describes as: "The wisdom of openness to truth...Truth does not lie within the grasp of one culture or religious tradition.. ${ }^{, 55}$ Further, Opoku's African cosmology results in no need for an ultimate salvation, as humanity has never been ontologically separated from God. Though their conceptions of who God is and of the meaning and place of Jesus Christ differ, both Barth (at least it is Barth's hope) and Opoku end up with God (or, Nyame as Opoku would refer to the divine) and all of humanity together. Bediako, on the other hand, holds to a position that a personal conversion experience (much like his own and the Apostle Paul's) is needed for each individual who would spend eternity with God.

Still, given these different perspectives on revelation and reconciliation, the possibilities for fruitful dialogue with other religious traditions can be seen. Opoku understands the traditional Akan religious beliefs to be an "open tradition" that is willing to accept all that is true. Thus, he can accept Christianity, up to the point that Christians make exclusive claims to truth or salvation. Opoku believes that truth about God is revealed in Christianity — and in Islam — and is willing to stretch to consider that Christ is actively revealing God through other religions, as they can represent "parables of the kingdom" and ways that God is revealing who God is to the world. Yet, Barth does not believe that the truth in non-Christian religions is complete or fully reveals who God is, since God can only be fully known in Jesus Christ. However, because of Christ's ongoing prophetic activity, Barth seeks to remain attentive to wherever God may be revealed.

In spite of being the recipients of incomplete revelation of God, adherents of non-

\footnotetext{
${ }^{55}$ Kofi Asare Opoku, "Post-colonial Church Cultures in Multicultural Societies," Plenary Panel address, Transatlantic Roundtable on Religion and Race, Accra, Ghana, 31 July 2013.
} 
Christian religions still are reconciled to God in Christ, for Barth, even if they are not living in correspondence to God's command. While Barth may intend this as gracious and comforting to his non-Christian dialogue partners, they may resist his assertion that God would make possible their reconciliation without their expressed consent.

Bediako agrees with Barth that the revelation that occurs within non-Christian religions is incomplete and insists that adherents of non-Christian religions must come to a saving knowledge of God in Jesus Christ in order to receive salvation. Although the terms pluralist, inclusivist, and exclusivist are not always helpful and often overused, it seems that Opoku would be a pluralist, Barth an inclusivist (kind of, since for Barth universal reconciliation only happens in Christ), and Bediako an exclusivist. ${ }^{56}$ It is interesting to note here that Barth, the European, is closer to Opoku, the practioner of ATR, than is Bediako, the African. Bediako's early exposure to American evangelicalism likely shaped his understanding of salvation.

This consideration of engaging a religiously pluralistic culture, preceded by the unexpected convergence about religion, and describing revelation as translatability or light, have expanded the understanding of both Bediako's and Barth's thought and have prepared the way for an integrated engagement that draws on and applies material presented thus far.

\section{IV.}

\section{Are we all syncretists?}

When considering practicing the Christian faith in a religiously pluralistic society, or the introduction of the Christian faith to a previously isolated society, a number of

\footnotetext{
${ }^{56}$ Hunsinger's description of Barth's position as either "exclusivism without triumphalism" or "inclusivism without compromise," is also apt. See Hunsinger, How to Read Karl Barth, 278.
} 
questions rapidly arise, including: How can the gospel of Jesus Christ and a given culture interact? Does translating the gospel into cultural forms always result in syncretism? Historically, accusations of syncretism flourish in times of pluralism or whenever the prevailing religious consensus is threatened. From the early centuries of the Christian Church to colonial Africa to Nazi Germany to modern-day Europe or $21^{\text {st }}$ century America, we find allegations of syncretism against some group that is combining gospel and culture inappropriately. ${ }^{57}$ In Calvin's Geneva, for instance, those who wanted to place images inside the sanctuary were labeled syncretists. ${ }^{58}$ Today as North America becomes more ethnically and religiously diverse, pluralism will continue to increase. Every expression of the Christian faith, too, will take on cultural forms and this process of translation will transform what it means to be "Christian" from one culture to another. Thus, as individuals seek to understand and establish their own Christian identity, these identities are constantly in flux as their culture changes and their understanding of the Christian faith changes.

For Bediako, African Christianity does not present a rupture with its primal religious past, but continuity. ${ }^{59}$ Even when Africans convert to Christianity, they do not, and in fact cannot, simply leave the primal imagination behind them. Instead, the impact of the primal religious imagination remains with them "in their being." Primal religions have shaped who Africans are and who Africans will be. ${ }^{60}$ The identity of an African

\footnotetext{
${ }^{57}$ For examples see, Lesslie Newbigin, The Other Side of 1984: Questions for the Churches (Geneva: World Council of Churches, 1983), 23; and more pejoratively, D.A. Carson, Becoming Conversant with the Emerging Church: Understanding a Movement and Its Implications (Grand Rapids: Eerdmans, 2009), esp. 200-202.

${ }^{58}$ John Calvin, Institutes of the Christian Religion, trans. Ford Lewis Battles (Philadelphia: Westminster John Knox, 1960), I.11.13.

${ }^{59}$ Bediako, "Their past is also our present," AICMAR 6 (2006).

${ }^{60}$ According to Bediako, "For the African theologian, however, the traditional religions, even if they constitute his past, are of the nature of an 'ontological' past, which means that together with the profession
} 
Christian is shaped by the past through the influences of pre-Christendom Christian theology and precolonial African primal religions. This twin heritage of African Christianity describes the presence of an indigenous Christianity within modern African culture. ${ }^{61}$ As such, Bediako considers the traditional religions of Africa as evangelical preparation for Christianity.

The presence of Christianity in Africa is the result of a movement of God from within African culture, not a foreign imposition from without. Such claims as these - that African Christian identity is singular, indigenous, and requires reclaiming from European influences - set Bediako in stark opposition to a leading theorist of postcolonial identity, Homi Bhbaba.

On the boundaries of spaces, cultures, borders, or historical ages, Bhabha theorizes that hybridity occurs when a past and a present come together and make something new. ${ }^{62}$ Bhabha's theory treats African Christians as a hybrid of two distinct entities, the African and the Christian. The African is the past, the prior identity that encounters the possibility of a Christian identity and results in a hybrid African-Christian future identity. Bhabha's approach therefore assumes difference where Bediako posits similarity and continuity. For both the African past and the Christian past are part of the history and identity of Africans. Neither one is foreign, there is not a hybrid, but a unified

of the Christian faith, it gives account of the same entity - namely the history of the religious consciousness of the African Christian" (CiA, 258).

${ }^{61}$ See also Bediako: "From the very early stages of the development of African Theology in the postmissionary era, virtually all the authors realized the necessity to learn and understand the indigenous knowledge systems of their own people. Subsequently, all serious African theologians trained in theology in Europe and North America, where these indigenous knowledge systems were not valued in the curriculum, have had to come to this realization, sooner or later, that is, if they were serious about making a contribution to theology as African Christians. Of course, some conservations tried to retain their 'imported theology;' but in that case, they were not able to help Christians grow in confidence and freedom as African Christians.” See Kwame Bediako, "A New Era in Christian History-African Christianity as Representative Christianity: Some Implications for Theological Education and Scholarship" JACT 9.1 (2006): 4.

${ }^{62}$ Homi Bhabha, Location of Culture (London: Routledge, 1994). 
whole. In fact, Bediako understands the entire postcolonial trope as detrimental to African Christian theology. For Bediako, "In positioning oneself as postcolonial, one is handicapped to understand one's indigenous heritage. ${ }^{, 63}$ By identifying oneself primarily with an "after-," such as after colonialism, one risks separating oneself from more basic or elemental truths about one's being, one's identity. Bediako did not want to lose the insights of the primal imagination from the pre-colonial period through a too hasty jump to the post-colonial.

Bediako resists postcoloniality, then, because he understands it as still defined by Western categories in its opposition to colonialism. He rejects the postcolonial paradigm, because he advocates an indigenous African Christian identity that is not entirely shaped, much less solely defined, by Western, European, or colonial history and ideas. Africans can encounter Jesus Christ without Western intermediaries by extricating African Christianity from the influence of Western Christianity, so that "African Christian theological scholarship will be making African Christianity less provincial but instead more truly universal!" ${ }^{64}$ As Christianity reconnects with its primal roots and relies on the Scriptures of the Old and New Testaments, a more universal and missional Christianity is revealed than the Western model of captivity to Western culture. And, the implications of this possibility are nothing less than the re-making of Christian theology itself. In fact, he muses hopefully that "the present shift in the centre of gravity may have secured for Christianity a future that would otherwise be precarious in the secularized cultural environment of the modern West.. ${ }^{, 65}$ For Bediako, Africa may have saved Christianity

\footnotetext{
${ }^{63}$ Kwame Bediako, “'Whose Religion is Christianity?': Reflections on Opportunities and Challenges for Christian Theological Scholarship as Public Discourse—The African Dimension" JACT 9.2 (2006): 48.

${ }^{64}$ Bediako, "Whose Religion is Christianity?," 47.

${ }^{65}$ Kwame Bediako, “'In the Bible. Africa walks on familiar ground.': Why the World needs Africa"
} 
itself.

His interest in articulating an indigenous understanding of Christianity where Christian identity comes from the gospel and not from cultural categories-whether colonial or postcolonial - is not limited to Africa. Bediako refers to this process as the "Re-Making of Christian theology." He appeals to the imagery of Peruvian theologian Gustavo Gutiérrez that African theologians need to guide people to "drink from their own wells" $"$ — prepared by God in Jesus Christ — while drinking themselves from these same wells. In this way, the future of African Christian theology can move forward without losing its rooting in its primal imagination. Such an identity may free African theology from any captivity to colonial or postcolonial categories toward the remaking of Christian theology for the world. In one of his earliest publications, Bediako mused: 'Why worry about syncretism in Africa, but not also in the West?' ${ }^{67}$ Bediako sought to assist Western Christians in identifying the cultural blind spots in their faith understandings.

Barth, of course, is very careful to make sure that nothing and no one impinges upon the sole mediatorship of Jesus Christ. He writes, "That He is the one Word of God means further that His truth and prophecy cannot be combined with any other, nor can He be enclosed with other words in a system superior to both Him and them" (IV.3, 101/112). Barth is delimiting two hypothetical possibilities that are theologically unacceptable. First, no combination or synthesis of the Word of God, Jesus Christ, and any other word, idea, religion, culture, etc., is allowed. There should be no Jesus plus culture or religion. If this addition is attempted then the sole witness and mediatorship of

AICMAR Bulletin 6 (2007); 38.

${ }^{66}$ See Gustavo Gutiérrez, We Drink From Our Own Wells (Maryknoll, NY: Orbis, 1984).

${ }^{67}$ See Bediako, "The Willowbank Consultation," 25-26. 
Jesus Christ is violated and the resulting combination is not Christian. Second, any attempt to place a system of thought above the Word of God, to subsume or confine Jesus Christ, or rein in his ongoing prophetic activity distorts "His truth and prophecy" and is theologically unacceptable.

In the midst of drawing these boundaries, Barth is quick to affirm God's sovereignty and the unstoppable, uncontrollable, and, for us, unpredictable, ongoing prophetic activity of Jesus Christ. Just because the Word of God "cannot be combined with any other" truth or prophecy, that does not restrict the Word from revealing who God is through true words or other media. Barth continues, "As the one Word of God, He can bring Himself into the closest conjunction with such words. He can make use of certain [people], making them His witnesses and confessing their witness in such a way that to hear them is to hear Him (Luke 10:16)" (IV.3, 101/112). Though humans are not theologically justified in using the Word of God for their purposes, the Word of God can use human words, and even humans themselves as witnesses for the Word of God. In fact, God has done this before and will do it again, for previously God "entered into a union of this kind with the biblical prophets and apostles" (IV.3, 101/112).

A connection can be identified between Barth's understanding of the ongoing prophetic activity of Jesus Christ and Bediako's understanding of traditional African religions as evangelical preparation for Christianity. Expressing Bediako's view in Barth's language: Jesus Christ, the Word of God, has chosen to bring himself "into the closest conjunction" with the traditions and expositors of African traditional religions. Christ makes them "His witnesses...confessing their witness in such a way that to hear them is to hear Him" (IV.3, 101/112). Barth certainly never considered this application of 
his understanding of Christ as Prophet. And both Barth and Bediako would be quick to point out that any such revelation that would occur through African Traditional Religions would be partial and incomplete. Further, Opoku would disagree with both theologians. As he expressed it (in relation to Bediako, but would also apply to Barth): "Kwame was wrong about this (evangelico preparatio). In traditional religions, Kwame saw the seeds of Christianity. I see the seeds and the fruit." ${ }^{, 68}$ However, Bediako and Barth share an understanding of the universality of revelation that allows for (and in Bediako's case at least, mandates) revelation through traditional religions in Africa, and presumably elsewhere as well.

For Barth, the Word of God, Jesus Christ, cannot be prevented from speaking through anyone and anything. After his claim earlier in the Church Dogmatics, that God could speak through a dead dog or a flute concerto, Barth clarifies that no one can prevent God from entering into unions with the words of people "outside the sphere of the Bible and the Church... as a form of [God's] free revelation of grace" (IV.3, 101/112). All revelation is in, by, and about Jesus Christ. Yet revelation can come through a variety of media. The revelation of God in Jesus Christ whether through true words, parables of the Kingdom, or traditional religions, can, at least in principle, be understood by Barth as gifts from God to humanity, expressions of God's grace.

God is active in revelation while humanity is receptive; God in Christ speaks through the Holy Spirit, while humans listen. However, Barth sees an inversion of the proper mode of revelation when Christians or non-Christians create syntheses between Jesus Christ as the one Word of God and any other words. These syntheses imply a

\footnotetext{
${ }^{68}$ Kofi Asare Opoku, personal interview, 31 July 2013, Ghana Institute of Management and Public Administration, Accra, Ghana.
} 
control over Jesus Christ, to which none of us has any right, and which can be only the work of religious arrogance (IV.3, 101/112). Barth's Christocentric focus is on full display as he insists on the unidirectional movement of revelation from God to humanity, never from one human to another - though at times, the Word of God may choose to use humans to witness to revelation. Humans, as recipients of God's self-revelation, must always be testing human words to see if they are pointing beyond themselves to the one Word of God, the Lord, the Prophet, Jesus Christ.

For Barth, the issue with Bediako's claim that humans can come to know God through traditional African religions would be the abiding connection that Bediako posits between Christianity and African traditional religion. Barth's fear is that if Christ were constantly revealed through traditional religions, then the freedom and distinctiveness of Christ would be lost. Does Bediako's understanding of Christ's revelatory presence within African Traditional religions amount, them, to a "suspiciously loud but empty utterance" in Barth's words (IV.3, 102/113-114)? For Bediako, God intentionally used and uses traditional religions to prepare Africans for the full revelation of God in Jesus Christ as revealed through the Scriptures of the Old and New Testaments. Bediako's understandings of creation, divine providence, and even history, are displayed through his belief in the infinite translatability of the gospel.

Barth uses the imagery of Jesus as the Light of Life to express the irrepressible nature of God's self-revelation. The Light of Life permeates all places and may use a parable of the Kingdom to reveal who God is, but God's presence (and corresponding revelatory intent) does not remain within the creaturely medium indefinitely. The revelation is real and true, though partial (as it was for Bediako). For Barth, the revelation 
that results from the parables and true words is ad hoc. An illustration: in the parable of the Sower (Mark 4:1-20, Matthew 13:1-23, and Luke 8:1-15), there is nothing special about the Sower, the seed, or the soils. This ordinary event became a parable of the kingdom through the way that Jesus incorporated it into his teaching. The revelatory meaning in the parable lies not in the media (the Sower, seed, or soils) but in the (true) words of Jesus Christ that reveal the Word (Logos) — God in Jesus Christ. God is not orchestrating events to create parables of the kingdom. The light of Jesus Christ shines widely upon all people, just for the sake of it, without requiring a deeper significance.

For Barth, humanity cannot apprehend a pristine gospel unadulterated with human culture. The Church is in the world and the world is in the church. While they can be distinguished they cannot be separated. Barth is quite clear that in many ways, the identity of Western Christians has become too cozy with Western cultural assumptions, including the exceptional view that a peculiar form of Western Christianity is best for the entire world. If one cannot identify the gospel in the life of a Christian or a Christian community, then the distinctiveness of the gospel has been lost.

The works of Bediako and Barth — in spite of their differences in theological emphases and socio-cultural locations — point to the impossibility of apprehending a "gospel" apart from material culture. Both appeal to the incarnation of the son of God in the person of Jesus of Nazareth as the key moment of gospel and culture coming together. Thus, though a pure gospel is not apprehensible, neither is the gospel inseparable from, nor identical with, culture.

Both Bediako and Barth point to a needed relationship between God's revelation and human cultural forms as the medium of that revelation. Is any such relationship 
necessarily syncretistic? If so, then all Christians are inherently syncretists. Yet, such an understanding mistakes any synthesis for syncretism and ignores the complexity of the diversity of encounters between the Gospel and culture, including hybridity. Simply because a theologian embraces insights from culture, does not necessarily imply “theological syncretism" (CiA, 67). Instead, Bediako understands

this engagement between Gospel and culture [to be] inescapable. It is not possible any longer to say, "This is culture and we cannot intermingle it with the Gospel." What is our identity? We cannot take ourselves out of our cultures and stand in sanitized, disinfected isolation from them. At the same time, this process need not cause anxiety. It need not terrorize us, because the engagement between Gospel and culture is what God has been about all along. ${ }^{69}$

Bediako stresses the use of vernacular languages and concepts in order to theologically engage local cultures. Since the human flesh that Jesus Christ, the divine Son, assumed in the Incarnation, is understood to be common to all humanity - of all colors, races, ethnicities, and cultures — then the presence of Christ and the accompanying conversations about Gospel and culture cannot be foreign to any culture. That is, every culture needs to navigate these questions in their own terms and own language. Bediako succinctly summarizes his position: "In short, the challenge is that of relevance without syncretism” (CiA, 85).

Barth demonstrated a similar awareness in his early Göttingen Dogmatics. He wrote: "Of none of us is it true that we do not mix the gospel with philosophy.", deeply understands that one's culture, or worldview as he often called it, always shapes readings of the gospel. All human beings are intimately affected by their worldviews and

\footnotetext{
${ }^{69}$ Bediako, "Gospel and culture: Guest Editorial," 1, Bediako's emphasis.

${ }^{70}$ Karl Barth, Göttingen Dogmatics, vol. 1, trans. Geoffrey W. Bromiley (Grand Rapids: Eerdmans, 1991, [1924]), 258, 259, emphasis added. See also Barth's description of the work of interpretation: "Free thinking with the help of authorities" (260).
} 
the philosophy they have imbibed. For Barth, God in God's self-revelation always uses creaturely media. Whether the self-revelation uses scripture, humanity, or other media, the process is one of God's continual veiling and unveiling of Godself. The light of Jesus' life shines and illuminates who God is and what God has done in reconciliation. The shining light of Christ's ongoing prophetic activity brings clarity and attention to the work of God that has already been accomplished in Jesus Christ and whose grace continues to work towards God's purposes in the world.

Bediako believes that one's identity is primarily rooted in Jesus Christ. The gospel of Jesus Christ is then infinitely translatable into any and all human cultures. Barth emphasized the priority of God's self-revelation over culture. Both authors developed Christocentric theologies — including their understandings of revelation, religion, and culture - that interpret the person and work of Christ. Bediako understands Christ's universality through his divinity by articulating an understanding of Christ as Spirit that enables him to be universally revealed to African peoples as an ancestor. Barth understands Christ's universality through his resurrection by articulating how Christ's atoning work achieved universal reconciliation for humanity with God. Both theologians appeal to the Epistle to the Hebrews-Barth offered a dogmatic reading and Bediako offered a cultural reading — to make distinctly theological claims about Jesus Christ and God's revelation. Both understand the encounter between the gospel and culture to occur in specific locations. At these moments, God's revelation intersects religion and culture. Bediako describes revelation through his concept of translatability that expresses how the gospel is contextualized into cultural forms. Barth uses the imagery of light to convey 
how God's self-revelation flows outward toward all people. Their views on religion demonstrate an unexpected convergence as both theologians offer strong critiques of religion as human projection that seeks to displace God's revelation in Jesus Christ. Their differing understandings of universal revelation (for Bediako) and universal reconciliation (for Barth) highlight Bediako's insistence on Christ's revealing presence within African culture and Barth's insistence that reconciliation must always precede revelation. For Barth, reconciliation is revelation, but revelation is not necessarily reconciliation. Revelation is a constituent part—the outward movement—of reconciliation. For Bediako, the revelation of God in Christ through African cultures and religions proclaims the possibility of eternal life with God. 


\section{Chapter 5 \\ Conclusion}

I would therefore dare to say that today I understand God better than I used to. This is due above all, of course, to the boundless grace of God, but my increasing understanding of African concepts of God was instrumental in the process. God used the richness of African religious experience to teach me more about his richness. - David Bosch ${ }^{1}$

These remarks from an unedited conference presentation offer a window into David Bosch's intellectual and spiritual self-understanding. Bosch, an Afrikaner who received a $\mathrm{PhD}$ in New Testament from the University of Basel in 1957 (and frequently cited Barth's work), had served as a missionary of the Dutch Reformed Church among the Xhosa-speaking people in Transkei, South Africa. He was fluent in Xhosa, Afrikaans, Dutch, German and English. He also frequently sparred with the leaders of the Dutch Reformed Church over their support of the apartheid regime. When his Western education encountered the religious lives of black Africans, he reflected deeply on the stark differences between Western and African concepts of God. He chose not to reject the African concepts of God (as many early missionaries to Africa had done), nor did he assimilate Africans ideas into Western ones, rather he opted to ruminate critically and humbly on these differences and learn from them. Bosch believed that the African religious experience communicated something about God that Westerners missed. The encounter with traditional African concepts of God challenged and significantly expanded Bosch's understanding of who God is.

\footnotetext{
${ }^{1}$ Bosch wrote this address without access to his books or other scholarly materials. When at a conference, he was asked to speak on the topic of "God through African Eyes," and since the address was published shortly thereafter, he did not have the opportunity to edit it. See David Bosch, "God through African Eyes" in Relevant Theology for Africa, ed. H.J. Becken (Durban: Lutheran Publishing House), 60, 73.
} 


\section{I.}

This dissertation has traced the responses of two theologians from distinct racial, ethnic, religious, and geographic starting points to the account of Christianity supplied by nineteenth century Protestantism. The tumultuous events of the twentieth century (including the Nazi Holocaust and rapid decolonization) demonstrated the insufficiencies of this theological and cultural narrative that had been taken for granted as the content of Christian faith. These two theologians each responded to this collapse from within his own culturally-embedded religious heritage.

The need to re-make Christian theology became evident to Bediako through his own experience of African and Western expressions of Christianity. His theology of négritude re-appropriated both the Christian past and the traditional religious past of Africans to assert a counter-narrative of Christian theological reflection over and against the Western model. His understanding of the world was indelibly shaped by his childhood within a British colony and his adolescence in a newly independent nation. He was drawn to the literature of négritude as a way of reclaiming an African past for the sake of shaping an African future. This academic interest allowed him to combine his work on European existentialism with his personal concern as an African to form a distinct African identity — separate from European influences. His academic work was consumed by the need to address distinctly African questions. After his exposure to European existentialism, Bediako abandoned his religious upbringing - a mixture of African traditional religion and nominal Christianity_-for an atheism that he would later describe as completely un-African. Following his conversion to Christianity, Bediako claimed he also became African again and turned his scholarly attention to African 
theological questions and the task of articulating an indigenous understanding of Christianity in Africa - one that might transform the future of Christianity not only in Africa, but worldwide.

Barth, too, hoped that his theological work would transform the work of Christian theology. His work was shaped by events in Germany in the 1910s, 1920s, and 1930s. Barth's early pastoral ministry was focused specifically on the plight of the Safenwil working-class. However, Barth's awareness of the broader theological and religious currents in Germany, particularly his disillusionment with the Kulturprotestantismus of his teachers and his exposure to the Blumhardts, led to a break with liberal Protestantism. Still, the Blumhardts left a lasting impression on Barth—particularly their emphasis on the resurrection and the ongoing activity of the Kingdom of God — that would play a significant role in Barth's Christocentric theology. While Barth never expected his pastoral ministry to evolve into an academic career, his theology of Krisis, articulated in his ground-breaking Epistle to the Romans, charted a new course for the young theologian. Barth now understood his task, in the tradition of John the Baptist, as the prophetic work of applying God's radical self-revelation to the interpretation of current events. Barth's witness to the alterity of Jesus Christ over and against the shifting winds of culture took on political dimensions as he became involved in the Confessing Church of Germany and served as the primary author of the Barmen Declaration in 1934. His role as a witness to God's self-revelation was continually to point to Jesus Christ, not to the shifting winds of culture. Barth's world was not static, even though he did not travel outside of Europe until the end of his life. He constantly engaged his students and their questions, as is evident on every page of his Church Dogmatics - that were first 
conceived and given as course lectures.

In spite of their dramatically different backgrounds, Barth and Bediako hold several significant parts of their theological heritage in common. While Barth inherited the legacy of nineteenth century liberal Protestantism directly through his teachers (who themselves were key players in the articulation of liberal Protestantism), Bediako received this legacy indirectly, through colonialism and through his formal education. There is significant overlap in their sources as well as the types of questions they engage in their writings. Collectively, their work can be considered to be part of one broad conversation within twentieth century Protestant thought. While both theologians cite Patristic authors extensively, Bediako functionally ignores theologians from the sixth century to the twentieth in order to circumvent the theology of Christendom and the pernicious influence of Enlightenment philosophy. Barth, on the other hand, engages and often seeks to correct this heritage. Although they also share many sources from the modern period, Barth notably omits the work of non-Western theologians. The most significant convergence of their shared inheritance is that of the Blumhardts. For Barth, this influence comes directly from both their writings and his visit with Christoph Blumhardt. For Bediako, this influence comes indirectly, through the work of the Basel mission in Ghana. The use and study of vernacular languages and an emphasis upon education characterized the work of the Basel Mission and prepared the way for Bediako to articulate a Christian theology indigenous to Africa.

Though Bediako and Barth addressed many similar themes and shared a common theological inheritance, their work also evinces a mutual suspicion of one another's culture. For Bediako, Western colonization had introduced damaging dichotomies into 
African societies and filled many Africans with a profound mistrust of European intentions. More personally, European existentialism, particularly the prominence of atheism, and the decline of Christianity in Europe, intensified Bediako's suspicion. He concluded that though Western Christianity was ultimately unsalvageable because of its complicity with Christendom, the laboratory of Africa provided new possibilities for the re-making of Christian theology worldwide. Further, Barth's racially insensitive remarks about a fellow Ghanaian allowed Bediako to uncritically lump Barth's work in with the rest of Western theology without giving it significant attention. While for the most part, Barth did not concern himself with Africa, or things African (aside from as a destination for missionaries), he made some provocative remarks toward the end of his life about non-Western peoples as producers (rather than mere consumers) of theology. It is possible that lifting his eyes from his work for some limited travel during his final years allowed him to reflect on these previously unconsidered possibilities.

\section{II.}

Bediako was just such a producer of theology, a theologian in his own right, and as such a peer of Barth's. A comprehensive analysis of Bediako's corpus reveals three interrelated theological themes that pervade his writings - revelation, religion, and culture - that are likewise central to Barth's mature Christological reflections. Bediako's understanding of how and why God's revelation occurs through human culture is encapsulated in his oft-repeated phrase: "the infinite translatability of the gospel of Jesus Christ." The translation of the gospel into vernacular languages and concepts becomes for Bediako the paradigm of faithful contextualization. On these terms, theology is the 
combination of a given cultural context and the distinctive truth of the gospel. This paradigm, together with his work in négritude, allows Bediako to give an account of African Christianity after colonization, recovering a traditional religious past alongside their Christian past in order to construct an African Christian identity. In this work, Bediako identifies himself with the mission of the Apostle Paul who made a similar effort to utilize a pre-Christian past in the service of a richer sense of Christian identity and mission in the present.

He first pursued his interest in identity through postgraduate work at the University of Bordeaux on the Congolese poet, Tchicaya U Tam'si. In his master's thesis, Bediako investigated Tchicaya's role as a mediator between African and European cultural categories. His doctorate continued his work on Tchicaya as a first, awkward attempt to bring together his understandings of an African and a Christian identitythrough a lens of American evangelicalism. At this time, Bediako developed an increasing sense of his own theological vocation. He met other evangelical Christians from the global South and began his formal theological education-first a bachelor's degree in theology and then a PhD in Patristics.

Bediako's understanding of an African Christian identity is based on his conviction that the gospel that was already within Africa (prior to the arrival of Europeans) is a key source for African theology. As this universal gospel is made explicit, it is translated into the fluid categories of human thinking and behavior (Bediako's definition of culture), yet this gospel must remain fixed on Jesus Christ; from these encounters of the gospel and particular cultural contexts, provisional theologies arise. Bediako's purposeful pursuit of identity, and his desire to recover the past for the 
sake of the future, led to his articulation of the twin heritage of African Christianity as a product of its precolonial African traditional religious past and its pre-Christendom Christian past. Bediako employs the work of Justin Martyr and Clement of Alexandria to illuminate similarities between the efforts of modern day African theologians and Hellenistic thinkers within the early church to engage their respective cultures. Bediako understands himself as a modern-day apologist for African Christianity based on his belief in the direct connection between God in Jesus Christ and Africans.

God's revelation (what Bediako calls "the gospel") is universal- that is, it is not specific to those Europeans who disseminated the gospel to the world. This universality of the gospel, together with its infinite translatability through Jesus Christ, is what makes the direct connection between God and Africans possible. His articulation of translatability is based in the incarnation (God-in-the-flesh) and allows for a Christian identity that is authentic and indigenous to Africa. Bediako's project counters the de facto understanding of many European missionaries to Africa that the translation process was complete when the gospel was articulated in European forms. While critical of many missionary presuppositions, Bediako is nevertheless grateful that the missionaries brought the Bible and the name of Jesus Christ to Africa; although they decidedly did not bring the presence or activity of God.

For Bediako, God has been present in Africa since humans first walked on the continent, and even before. He draws on the work of earlier African Christian theologians to assert that African Traditional Religion (ATR) is continuous with Christianity; as such Christianity is indigenous to Africa. In the divine economy, Bediako understands ATR to be evangelical preparation for Christianity. The names for God that Africans have used 
for millennia have always described God in Jesus Christ. These pre-Christian traditions reflect the primal religious imagination that forms the substructure of African Christian thought. Western, European Christianity is impoverished because, in part, the primal imagination has been nearly eliminated from Western culture. The importance of the primal imagination is that it reflects the importance of the spiritual over against the material in African cosmologies. This imagination remains within Africans, in their being, even after a conversion to Christianity. This ongoing connection between African Christianity and African culture seeks, for Bediako, to keep African Christianity grounded in the everyday realities of Africans, not in abstract categories (as had happened in the West).

The interrelation between revelation, religion, and culture - the three main themes of Bediako's thought—already evident in the translation of the gospel into cultural forms, the continuity of ATR with an indigenous African Christianity, and the primal imagination as the substructure of African Christianity—is most vividly displayed in Bediako's treatment of the central aspect of traditional African religion and culture: the veneration of lineage ancestors. Bediako believes that all African Christian theologies must articulate a theology of ancestors so as to prevent African Christians from simultaneously living in two thought worlds - the African and the European (Western). Bediako constructs an ancestor Christology based on Jesus' position as universal savior and emphasizes Jesus' divinity over the particularities of his humanity. Jesus' resurrection and ascension return him to the realm of the spirits, overcoming death and enabling him to rule over the world - the entirety of the material and spiritual realities. 
Although the articulation of an ancestor Christology is not unique to Bediako, he is clear that unlike other ancestor Christologies, his account of the risen Christ as the supreme ancestor destabilizes traditional political structures that are based on familial succession mediated by the ancestors. In spite of his overall valuation of ATR, for Bediako the ancestral cult is not sacred. In fact, in Jesus' death and resurrection, the ancestors are revealed as a myth, a projection of African cultures. As the supreme ancestor, Jesus Christ displaces natural ancestors. Although both non-Christians and Christians criticize Bediako's view, he believes that vernacular translations of the Christian scriptures support him.

The implications of Bediako's understanding of revelation, religion, and culture from within his African context are numerous. An understanding of the translation of the gospel of Jesus Christ into vernacular African languages and concepts as African Christianity assumes a religiously pluralistic society that is able to simultaneously affirm the uniqueness of Jesus Christ and the integrity of non-Christian faiths. Bediako's claims that the indigeneity of Christianity in Africa and the continuity of ATR with Christianity assert the Christian faith as a non-Western religion that cannot be contained by any single culture. This assertion requires certain, flawed Western understandings of the Christian faith to be remade and reconceived in light of the growth of Christianity in multiple centers around the world. These diverse expressions of the Christian faith worldwide share the same revelation of God in Jesus Christ, but as the gospel is translated into specific cultural contexts, these diverse indigenous responses may share few practices in common. 


\section{III.}

The nineteenth century Western model of theological reflection frustrated Karl Barth as it did Bediako. In his analysis of the state of the Church since the Reformation, Barth identified a rupture between prevailing Protestant practices, on the one hand, and the gospel of Jesus Christ, on the other. Barth treats the same themes of revelation, religion, and culture that characterize Bediako's corpus in close proximity in his own mature Christology that examines the prophetic office in Church Dogmatics IV.3, §69. Intriguingly, Barth's articulation of the ongoing prophetic activity of Jesus Christ bears significant similarities to Bediako's articulation of the infinite translatability of the gospel.

Barth understands the prophetic office of Jesus Christ to proclaim and publicize the priestly and kingly work of Christ in justification and sanctification. He sees Calvin's rediscovery of Christ's threefold office (that Barth re-orders as priest, king, and prophet) at the time of the Reformation as no coincidence. The process of secularization that began in the sixteenth century continued into the twentieth, and Barth believed that the liberal Protestantism of his day was the logical (and terminal) expression of the alienation of Christian religious principles from the person of Jesus Christ. For Barth, a new approach was needed.

Barth employed an actualistic understanding of story-as-history (Geschichte) to ground theology — particularly his doctrine of God and Christology — in the concrete events of the life, death, resurrection, and ascension of Jesus Christ, rather than in abstract metaphysical categories. For Barth, the event of reconciliation is finished and ongoing. As such, the resurrection of Christ as history is inseparable from Jesus' 
incarnation, crucifixion, and ascension. The resurrection prophetically proclaims, "Jesus is Victor!" not an abstract triumph of grace. One can even go so far as to say that God's self-revelation is completed in Christ's resurrection and ascension.

Barth's understanding of God's self-revelation has three elements: 1) all revelation is God's self-revelation, 2) revelation is for all people, and 3) revelation is ongoing. God's self-revelation in Jesus Christ decenters and relativizes human religion, and always occurs through cultural media. Revelation also proclaims what has already been accomplished in the reconciling work of Christ. In this way, reconciliation is revelation. Revelation is the outgoing and ongoing publicizing of the work of Christ that always proclaims the one Word of God in Jesus Christ, and can occur through any cultural form God chooses - from a dead dog to a Mozart concerto to a parable of the Kingdom. Barth's mature Christology offers a more detailed and expansive account of how revelation occurs outside the Bible and the Church through the ongoing prophetic activity of Jesus Christ. Barth uses the imagery of light, which is closely tied to his claims about the inherent glory of God, to describe how the ongoing prophecy of Jesus Christ is universal. The light of Christ shines on all people in all places; it does not require permission or acknowledgement. Further, in the ongoing prophetic activity of Jesus Christ, God's self-revelation establishes knowledge by shining the light of truth. Christ's presence in history penetrates culturally-bound worldviews and philosophical systems. Just as in the incarnation, Jesus Christ stands as the concrete embodiment of the selfrevelation of God in a particular historical moment and cultural situation. So too, all ongoing prophetic acts are embodied in cultural forms. The self-revelation of God continues today through true words and lesser lights that enkindle human knowledge 
about God's actions toward humanity in Jesus Christ. God's self-revelation of God is ongoing and for all people.

Barth's exposition of the parables of the Kingdom of Heaven in IV.3, $§ 69$, clarifies the relationship of Jesus Christ as the Light of Life to the lesser lights of the parables. In God's sovereignty and through the ongoing prophetic activity of Christ, the self-revelation of God occurs through the occasional use of material culture - the lightsto proclaim the already-accomplished reconciling work of Christ. The significance of these parables is that they take place outside the Bible and the Church, not that they are somehow "secular" parables. The issue at stake is where the parables occur, not the nature or character of the parables themselves - cultural media are neither "secular" nor "sacred." Barth's articulation of the parables of the kingdom collapses this strict dichotomy by describing how revelation penetrates the entire sphere- both the center and the periphery. There are degrees of "secular," but not a sharp distinction. As revelation penetrates human cultures, the movement of God and of the Christian community is continually outward, in service of one's neighbor.

The concrete, actual, outward movement of God, and God's people is an expression of Barth's understanding of Christ's prophetic office that challenges the establishment of Christianity as a religion. Barth considered the category of religion in I.2, $§ 17$, under the title: "The Revelation of God and the Sublimation (Aufhebung) of Religion." There, Barth voiced his criticisms of basing Christianity on any abstract principle. He was particularly concerned that principles were susceptible to manipulation (and replacement) by human projection. God's self-revelation places all religion under 
judgment. Indeed, God judges Christianity's apostasy more severely than other religions, precisely because, through revelation, Christianity can be the true religion.

Barth approvingly appealed to Feuerbach's analysis of the essence of Christianity as projection. His solution in $\S 17$ claimed that the name of Jesus Christ is what made Christianity the true religion. However, after his exposition in $\S 69$, the name is revealed as a mere placeholder for his (later) more thorough exposition of Christ's person and work. In light of $\S 69$, the Christian faith must be based solely on the actual history of the person of Jesus Christ as revealed in the Christian scriptures and the ongoing prophetic activity of Christ —not human projection, nor merely the name of Christ. Barth affirmed that Christians are asking different questions than Feuerbach, because Christians begin from a position of always already having been encountered by God's self-revelation in Jesus Christ; they do not begin from self-projection. God's self-revelation is the only "point of contact" between God and humanity, but that contact can occur outside the Bible or the Church. As the ongoing prophetic activity of Jesus Christ moves outwardfocusing the Christian faith not on principles, but on the person of Christ—and establishes some kind of knowledge, it redefines the category of religion. In $\S 69$, Barth reaffirms the claim from $\S 17$ that a principle, such as the grace taught in Pure Land Buddhism, is not sufficient for a true religion. In this later exposition, however, the name of Jesus Christ—while necessary—is not sufficient. The only sufficient basis for the Christian faith is the actualized history of the person of Jesus Christ: a history that is ongoing and calls the Christian community forward. 


\section{IV.}

In his exposition of the parables of the Kingdom of heaven through the ongoing prophetic activity of Jesus Christ, Barth is famously reluctant to provide specific cases of contemporary parables. Bediako's claim of revelation through ATR offers just such a case. Through a critical comparison with Barth's thought, Bediako's understandings of revelation, religion, and culture, articulated through his expositions of the translatability of the gospel, the continuity of Christianity with ATR, the indigeneity of Christianity in Africa, and the primal imagination as the substructure of African Christianity, gain clarity and precision. For both theologians, revelation undergirds the rest of their theological project. Both of their theologies are Christocentric in a generative sense that causes them to rethink Western understandings of religion. And, for both, one must respond to the revelation of God from within one's own material culture.

Bediako's and Barth's attention to the Epistle to the Hebrews demonstrates ways that both theologians draw upon an emphasis on the divinity of Christ in this letter-for Bediako in his ancestor Christology; and for Barth, by connecting the opening verses of Hebrews with the prologue of John to shape his understanding of Christ as prophet. Bediako saw tremendous cultural relevance in Hebrews for Africans. He uses Hebrews to assert the direct, unmediated relationship between God and Africans through Jesus Christ as universal savior, high priest, and supreme ancestor. He emphasizes Jesus' divinity in order to deemphasize Jesus' non-African, specifically non-Akan, ethnicity. Christ's universality allows him to not be a stranger to Africans and the African heritage; just as Hebrews interpreted Jesus Christ a high priest who was not a Levite, but in the order of Melchizedek. This connection of Jesus to the African heritage enables and encourages the 
use of vernacular terminology in African Christianity and theology. Yet Bediako's understanding of Christ's universality is not confined to Africans, but applies to all peoples. This understanding of universality, when joined with Bediako's views on identity and history articulated in his reading of Hebrews - by emphasizing Jesus' divinity over his humanity—approach, but ultimately do not fall into the trap of monophysitism. Christ's universality pervades Bediako's understanding of human ontology, specifically that the primal imagination remains within Africans following their conversation to a fuller, complete understanding of God through Jesus Christ.

While Barth would agree that human ontology is understood in relation to God's self-revelation in Jesus Christ, he articulates a full-blown theological anthropology that treats Jesus Christ as the sole source for the formation of human beings. If Bediako holds on to the formative role of the primal imagination in addition to Christ's role, Barth did not understand a later human awareness of one's identity to create an ontological past. For Barth, the true human, Jesus Christ, is determinative of what it means to be human for all humans whether they know it or not. In contrast, Bediako understands knowledge about Jesus Christ as offering wisdom for questions about life, religion, and culture, but he is not willing to let go of the constitutive influence of ATR on African Christian identity. Thus, for Barth, though God might on occasion use ATR as a revelatory parable of the Kingdom, he would be reluctant to embrace Bediako's ancestor Christology as something different than, or additional to a theology determined exclusively by the history of Jesus Christ.

Bediako further employed Hebrews to demonstrate the overlap between African Christianity and traditional Akan cultural and religious festivals. Specifically, Bediako 
claims that the purification sought in the annual Odwira festival is analogous to Christ's work of purification described in Hebrews proving that Christ had a stake in traditional religion. Barth, while potentially willing to affirm the Odwira festival as a parable—after testing its true words against the witness of scripture - could not describe the connection between revelation and culture through the resurrection and Christ's ongoing prophetic work as an abiding, perpetual presence within a specific cultural form. For him, the event of reconciliation publicized and animated by Christ's resurrection continues to proclaim who God is through contemporary cultural media. The outshining of Christ's light transforms what it means to be human and how humans are to live. Bediako, on the other hand, understands the resurrection as the theological response to the theological problem of death, by returning Christ to the spiritual realm.

Regarding revelation more generally, Barth uses the opening verses of Hebrews to assert the ongoing revelation in Jesus Christ, even though the author of the Epistle did not consider such a possibility. Bediako agrees that the author of the Hebrews believed that revelation was finished and complete, but seeks to replicate the author's methodconstructing Christology as an African Christian in a similar manner as the writer of Hebrews constructed his theology as a Jewish Christian. Bediako's reading adheres more closely to the perspective articulated in Hebrews (with the notable exception that Bediako is using Hebrews to articulate Jesus' universality, not his particularity as a Jew), whereas Barth takes the opening verses of Hebrews beyond their author's intention by using John's prologue in order to defend the ongoing prophetic activity of Jesus Christ. Hebrews — as a work of translation into cultural concepts—suits Bediako's project well, as does its engagement of topics of interest to African religiosity, including priesthood 
and sacrifice. Barth appeals to the Hebrews and John to make an argument about the ongoing nature of Christ's prophetic work outside the walls of the church. For Barth, God's self-revelation is not restricted to any single cultural manifestation. Bediako's account of revelation, on the other hand, is more static, and more concerned to strip away any foreign cultural trappings that might prevent the gospel's translatability into vernacular (particularly African) concepts. Following the approach of the author of Hebrews, then, the universal Christ is not a stranger to any human culture. The choice of Hebrews and John as favorite books for interpretative arguments by Bediako and Barth is evidence of their shared Christological focus.

Both theologians' articulations of revelation assume and require that revelation occur in a specific time and place. Bediako describes revelation as translatability while Barth employs the imagery of light. John's gospel provides resources for both accounts, as the Word became flesh and light shined into darkness. Barth's connects the Word, Jesus Christ, to true words in parables of the Kingdom through Christ's ongoing prophetic activity. Bediako understands Christ's presence in Africa in two steps: that Christ has always been present in Africa, yet that presence was implicit, or hidden, until the missionaries arrived with the scriptures and the name of Jesus Christ—only then was God in Christ completely revealed to Africans. Barth would reject the assertion of Christ coming to Africa as distinct from Christ coming to humanity as a whole. God's eternal decision to be God-in-relationship with humanity applies to all humans in all times and places. Jesus as the Light of Life shines on all people publicizing God's reconciling of all for everyone to see. Barth maintains his emphasis on the person of Jesus Christ and might worry that Bediako's understanding of "the gospel" could, potentially, be abstracted into 
a principle, including the translation principle. For Barth, while God always uses creaturely media, God occasionally uses media that are not scripture and preaching. In translation, the temporal gap that Bediako posits between the "beginning" and the "incarnation" clashes with Barth's understanding that the second person of the Trinity had a name from eternity, that is, Jesus Christ, the incarnate one. Bediako would resist Barth's assertion of revelation over and against human agency; Bediako wants to preserve the role of human culture and religion in the reception of revelation.

In terms of religion, both Bediako and Barth criticize religion as a form of human projection. Bediako believes that the central aspect of ATR - the veneration of ancestors to acquire favor-is a myth. The ancestors have no real power since they are dead human beings; only the risen Jesus Christ has power in the spiritual realm to influence earthly events. Though criticized for his ancestor Christology, Bediako cannot leave the ancestors alone. He believes that for Christianity to be relevant to Africa, there must be a Christian theology of ancestors, and a corresponding theology of ATR. While Bediako wants to affirm a place for ATR in the constructing of African Christianity, Barth wants to abolish all understandings of religion, including Christianity, as contributing to one's salvation. Barth seeks the active presence of Christ behind human projections. The name of Christ is a necessary, but not sufficient condition, for Christianity to be the true religion. Bediako also underlines the importance of the name of Jesus Christ to the Christian faith, however he understands the name, as introduced by European missionaries, to complete the partial revelation of God through ATR. Whereas Barth begins with the name and moves to the person in order to articulate true religion, Bediako begins with true religion that needs the name of Jesus and the scriptures to be completed. 
Barth might then ask how the name and the scriptures (who together reveal the person of Christ) would modify Bediako's understanding of the true religion that comes to be called African Christianity.

In spite of their shared emphasis on the single, exclusive name of Jesus Christ as necessary for true religion, Bediako and Barth offer ways to engage religious pluralism through their distinct understandings of how universal revelation (for Bediako) and universal reconciliation (for Barth) relate to their understandings of salvation. Bediako's understanding of salvation requires an individual human response to God's revelation (through ATR and the Christian scriptures) but not a personal confession of sin. For Bediako, there is universal revelation without universal reconciliation, for the relationship with God was never ruptured — only partially understood. Barth's understanding of God's eternal election of humankind to be in relationship with God and the event of reconciliation in Christ's life, death, resurrection, and ascension, means that he believes, in the universal reconciliation of God and humankind. Barth hopes that all humans will live in correspondence to God's command and embrace reconciliation, but Barth does not see enough scriptural evidence to support such a doctrine of universal salvation. In contrast to Barth's claim of universal revelation through universal reconciliation, traditional African religions claim universal revelation within African culture. Bediako adopts the traditional African understanding of revelation alongside Barth's understanding of the necessity of Jesus Christ.

Having engaged each of the three themes individually, the interrelatedness of revelation, religion, and culture requires that they be considered together around contemporary questions concerning the engagement of the gospel and culture(s), 
including syncretism. Simply put, syncretism is a label for a combination of the gospel and culture where the one applying the label determines that there is too much culture and not enough gospel— that is, that the gospel had lost its distinctiveness. Such accusations occur most often in settings of religious pluralism or when an existing cultural and religious consensus erodes and a new one is negotiated.

Bediako seeks to insulate African Christianity from charges of syncretism by asserting the indigenous nature of Christianity in Africa. He uses his understanding of continuity to contest the application of hybridity by postcolonial theorists to African Christianity. Bediako's articulation of an authentic African Christianity seeks to place African Christianity on its own secure footing, so that it is not subject to postcolonial or colonial cultural categories. African Christian thought can then be seen to have a universal impact on the process and content of theological reflection worldwide.

Barth seeks to protect the sole mediatorship of Jesus Christ in revelation. No combinations of the Word of God, Jesus Christ, and any other word are allowed—neither in practices nor in a system of thought. Yet in God's sovereignty, the Word of God cannot be prevented from speaking through any cultural form. Humans are to listen, receiving the self-revelation that God offers whether through scripture or a parable of the Kingdom when the one God known to us in Jesus Christ speaks. Humans must then test any words that occasionally, and unpredictably, come through parables and true words. The Light of Life shines on all peoples and enkindles revelation through cultural media as God so chooses.

In fact, the works of Bediako and Barth point to the impossibility of apprehending the gospel apart from material culture. All encounters with the gospel must take place in 
the human cultural realm, but while that means that the gospel and culture must mix, it does not lead to syncretism. For Bediako, the gospel of Jesus Christ is infinitely translatable into any and all human cultures; Christian identity is rooted primarily in Jesus Christ. Barth emphasized the priority of God's self-revelation over culture, but used cultural forms to convey revelation. Both theologians maintain a Christological focus in revelation that in turn penetrates culture and redefines religion. Their conclusions, illuminated through this comparison of divergences and convergences, can guide the work of contemporary constructive theology that seeks to navigate questions of the interrelationship of revelation, religion, and culture now and in the future.

\section{V.}

My aim in this work has been to walk my readers through a process similar to that which Bosch expressed in the epigraph to this chapter. For Western readers, my hope is that through encountering Kwame Bediako's work that their doctrine of God, Christology, and understanding of religion and the gospel-culture encounter, might be defamiliarized and their taken-for-granted assumptions might become recognizable, enabling these assumptions to be articulated and critiqued. For African and other nonWestern readers, my hope is that through exposure to Karl Barth's mature Christology, distrust of Western theologians might be somewhat ameliorated, while gaining a greater appreciation for Western thought-patterns and increased confidence that one of "their own" has significant contributions to make to contemporary theological conversations. For all, my hope is to see an increasing number of theologians and Biblical scholars in the global South publish their work in ways that will continue to advance these cross- 
cultural theological conversations. ${ }^{2}$ I would like to see, encourage, and learn from future scholars who will place theological figures from different parts of the world in intentional dialogue as I have done here.

One way of framing this dissertation is to suggest that twenty-first century theological reflection cannot take place in isolated silos. Because the richness of God cannot be captured within a single cultural framework, current and future theological work in fact needs to be transcultural. Fernando Ortiz coined this neologism and defined it as follows:

the highly varied phenomena that have come about... as a result of the extremely complex transmutations of culture...[that] expresses the different phases of the process of transition from one culture to another because this does not consist merely in acquiring another culture...but the process also necessarily involves the loss or uprooting of a previous culture...In addition it carries the idea of the consequent creation of new cultural phenomena...[T]he result of every union of cultures is similar to that of the reproductive process between individuals: the offspring always has something of both parents but is always different from each of them. ${ }^{3}$

Though Ortiz is focused on the history of Cuba — and the "intense, complex, unbroken process of transculturation of human groups [there], all in a state of transition, ${ }^{, 4}$ his insights can be applied more broadly to the constructive work of theology today. Today's rapid technological changes - both in transportation and information — create more dynamic cultural environments than Barth, Bediako, or Ortiz, experienced or envisioned. These changing cultural contexts are constantly creating new questions to be addressed by new theologies - that is, fresh interpretations of the Christian scriptures, tradition, and

\footnotetext{
${ }^{2}$ Among others see J. Kwabena Asamoah-Gyadu's books: African Charismatics: Current Developments within Independent Pentecostalism in Ghana (Leiden: Brill, 2005) and Contemporary Pentecostal Christianity: Interpretations from an African Context (Oxford: Regnum, 2013).

${ }^{3}$ Fernando Ortiz, Cuban Counterpoint: Tobacco and Sugar, trans. Harriet de Onís (New York: Knopf, 1947), 97, 103.

${ }^{4}$ Ortiz, Cuban Counterpoint, 103.
} 
practices in rapidly evolving and constantly changing cultural and religious environments. 


\section{ACKNOWLEDGMENTS}

"If you want to run fast, go alone. If you want to run far, go together."

As I consider this African proverb, and remember how far I and this project have come, many faces spring to mind of those who have run with me, without whom, this dissertation would not be in your hands. Most immediately, I wish to thank my advisor, Paul Dafydd Jones, for his unflagging enthusiasm for this project from its beginning and his attentive reading and incisive comments on multiple drafts that shepherded this project to completion. My dissertation committee, Maurice Apprey, Cindy HoehlerFatton, Charles Marsh, and Chuck Mathewes, offered significant support and encouragement in big and small ways throughout my doctoral program. In the final editing stages, I benefitted from Ashleigh Elser's comments on chapter 5 and Matt Puffer's thorough comments on the entire draft. In doing so, Matt not only significantly improved the final product, but provided a fitting conclusion to our graduate school journey together. I look forward to returning the favor shortly.

More broadly, I wish to express my thanks to the wider academic community at the University of Virginia. The interdisciplinary possibilities of the PhD program in Theology, Ethics, and Culture offered vital opportunities to practice articulating Christian theological claims in a religiously pluralist environment. My coursework outside the Religious Studies department in Postcolonial Theory with Mrinalini Chakravorty and in Sociology of Religion with James Davison Hunter provided helpful frames for 
understanding Bediako's intellectual history and conceptualizing "Christendom" as an interpretative category. Hunter's Institute for Advanced Studies in Culture, where I was an associate fellow, offered additional cross-disciplinary input over numerous lunch seminars and the use of an office. Three awards from the Graduate School of Arts and Sciences: a Buckner W. Clay award from the Institute for Humanities and Global Cultures; an Arts, Humanities, and Social Science summer research fellowship in 2012 that funded my first trip to Ghana; and a 2013 Society of Fellows Summer Research Fellowship that funded my return research visit, supplied encouragement and financial support at important stages of the project. In addition, the Public Humanities Fellowship in South Atlantic studies from the Virginia Foundation of the Humanities provided helpful research funds and the opportunities to engage fellow graduate students across the University in themes related to the peoples of West Africa and the Caribbean. Many, many thanks to the staff of the Interlibrary loan department of the University of Virginia who obtained numerous documents for me over the years from libraries around the world. This research would literally not have been possible without their efforts. Finally, I gratefully acknowledge the support of the Louisville Institute's Dissertation Fellowship in 2013-2014 that enabled me to complete my dissertation in a timely manner.

On a more personal level, I am especially grateful to Gillian Mary Bediako (and to Tim Dearborn for introducing us!) for her warm hospitality in Akropong and willingness to trust me with her late husband papers on two visits to Ghana. The entire staff of the Akrofi-Christaller Institute - particularly Benhardt Quarshie, rector; Ben Asiedu, Acting Registrar; and the archivists and librarians—Patience, Rose, and Mikemade my visits enjoyable and extremely worthwhile. My understanding of Bediako's 
French theses was greatly enhanced by the time and attention of my wife's uncle, Tom Petty, who assisted me with my French translations on a number of occasions. A special thank you as well to my mother for transcribing three of Bediako's lectures from audio files. I am grateful to her and to my father for their love and support throughout this project. My wife's parents also enabled me to run the long road of doctoral work through their encouragement and help with my family.

Finally, and most importantly, I am grateful to my children who welcomed me home at the end of each day of work with a hug, a smile, a ball, or a toy. When we moved to Charlottesville, Simeon was an energetic preschooler, Elliana was a toddler, and Jeremiah, but a twinkle in our eye. Five years later they have grown in so many ways and encouraged me every step of the way. I dedicate this work to Saranell, my wife and partner in life's journey. I could not have conducted this research or written it up with out her daily support, her constant encouragement and belief in me, and loving and generous spirit. 


\section{APPENDIX}

\section{Complete Writings of Kwame Bediako in Chronological Order}

1970

Négritude et Surréalisme: Essai sur l'oeuvre poétique de TCHICAYA U TAM'SI, T.E.R., Bordeaux III, October 1970. Unpublished M.A. Thesis.

1973

L'Univers Interieur de TCHICAYA U TAM'SI Thèse de 3e cycle, L'université de Bordeaux III, July 1973. Unpublished doctoral thesis.

1978

"Response to Taber: Is there more than one way to do theology?"

Gospel in Context 1:1, 13-14.

1979

"[Response to] David Hesselgrave: dialogue on contextualization continuum" Gospel in Context 2:3, 12-13.

1980

"The Willowbank Consultation, January 1978-a personal reflection"

Themelios 5:2 (January), 25-32.

"Review of African theology en route" Journal of Religion in Africa 11:2, 158-159.

"Review of Toward an African Theology" Journal of Religion in Africa 11:3, 235-237.

1983

Identity and Integration: An Enquiry into the Nature and Problems of Theological Indigenization in Selected Early Hellenistic and Modern African Christian Writers. Ph.D Dissertation at University of Aberdeen (July 1983). Later published as Theology and Identity (1992).

1984

"Biblical Christologies in the context of African Traditional Religion" in Sharing Jesus in the Two-Thirds World, eds. Vinay Samuel and Chris Sugden Grand Rapids: Eerdmans, 81-121. 
"Liberation Theology: An Evangelical View from the Third World (Book Review)" Transformation 1:1 (Jan-March), 28-29.

1985

"The Holy Spirit, the Christian Gospel and religious change: the African evidence for a Christian theology of religious pluralism" In Essays in Religious Studies for Andrew Walls, ed. James Thrower. Aberdeen: Department of Religious Studies, University of Aberdeen, 44-56.

"The missionary inheritance" in Christianity: A World faith, Robin Keeley, ed., Tring: Lion

1986

"Christian tradition and the African God revisited: a process in the exploration of a theological idiom," in Witnessing to the Living God in contemporary Africa eds. David Gitari and Patrick Benson. Nairobi: Uzima Press, 77-97.

1987

"Christ in Africa: Some Reflections on the contribution of Christianity to the African Becoming," in African Futures: $25^{\text {th }}$ Anniversary conference proceedings held in the Centre of African Studies, University of Edinburgh, 9-11 December 1987 Christopher Fyfe and Chris Allen, eds. Edinburgh: Centre of African Studies, $447-458$.

1988

"The Ultimate Vision: New Heaven and New Earth: Bible Study on Revelation 21:1-4" in Mission Studies 5:2, 32-38.

"African Christian Theology," "Theology of African Independent Churches," "Culture," and "Black Theology," in New Dictionary of Theology

Sinclair Ferguson and David Wright, eds. Downers Grove, IL: InterVarsity Press.

1989

"The roots of African Theology," International Bulletin of Missionary Research, 13:2 (April): 58-65.

"Into all the world," in Jesus 2000, Richard Bauckham et al., eds. Oxford: Lion Publishing, 222-225. 
"World evangelisation, institutional evangelicalism and the future of the Christian world mission," in Proclaiming Christ in Christ's way-Studies in integral evangelism, V. Samuel and A. Hauser, eds. Oxford: Regnum Books, 52-68.

1990

Jesus in African culture - a Ghanaian perspective. Accra: Asempa Publishers; reprinted 1992. Also in William A. Dyrness, Emerging voices in global Christian theology, Grand Rapids, MI: Zondervan, 2003, 93-121; and as chapter 2 in Jesus and the Gospel in Africa (2000).

1991

"Death and the gospel in the Ghanaian context" Exchange 20:2, 147-149.

"The relevance of a Christian approach to culture in Africa," in Christian education in the African Context, (Proceedings of the first Africa regional conference of the International Association for the Promotion of Christian Higher EducationIAPCHE, 4-9 March 1991, Harare, Zimbabwe, Grand Rapids: IAPCHE), 24-35.

1992

Theology and Identity: the impact of culture on Christian thought in the second century and modern Africa. Oxford: Regnum Books, 1992, reprinted 1999.

Ton Crijnen, "What you Need is a New Willibrord" (ET). Interview with Kwame Bediako in Trouw, 22 April 1992.

"New paradigms on ecumenical co-operation: An African perspective" International Review of Mission (July): 375-379.

"Challenges of Ghana's Fourth Republic: A Christian Perspective"

The William Ofori-Atta Memorial Lectures $\left(7^{\text {th }}-9^{\text {th }}\right.$ October 1992). Accra

\section{3}

"Unmasking the powers - Christianity, Authority and Desacralisation in modern African politics,' in Christianity and Democracy in Global Context, John Witte, ed. Boulder: Westview Press, 207-230.

"Cry Jesus! Christian Theology and Presence in Modern Africa" Vox Evangelica XXIII (April): 7-25. Reprinted as chapter 1 in Jesus and the Gospel in Africa.

"John Mbiti's contribution to African Theology," in Religious Plurality in Africa: Essays in honour of John S. Mbiti, Jacob Olupona and Sulayman S. Nyang, eds. New York: Mouton de Gruyter, 367-390. 
"Reflectors Report" Mission Studies 10 no 1-2 1993, 244-247.

1994

"Understanding African Theology in the twentieth century" Themelios 20:1 (October): 14-19.

"Christ is Lord! How is Jesus Christ unique in the midst of other faiths?" Trinity Journal of Church and Theology (Legon) 14:2 (Dec. 1994-Jan 1995), 50-61.

"The unique Christ in the plurality of religions" in The Unique Christ in our pluralist world, Bruce Nichols, ed. Grand Rapids: Baker, 1994, 47-56.

1995

"The impact of the Bible in Africa" Epilogue in Ype Schaaf, On their way rejoicingThe history and role of the Bible in Africa. Carlisle: Paternoster Press, 243-254.

"The significance of modern African Christianity-A Manifesto," Studies in World Christianity (The Edinburgh Review of Theology and Religion) 1:1, 51-67.

"What is the Gospel?" ATF Bulletin 1, 6-7. See later "What is the Gospel?"

Transformation 14:1, Jan/March 1997, 1-4. (originally presented as part of the Asempa Jubilee Lectures, 27-29 September 1995 in Accra, Ghana.)

"De-sacralisation and Democratisation-Some theological reflections on the role of Christianity in nation-building in modern Africa," Transformation 12:1 (JanMarch 1995), 1-4.

"Theologie van het grondvlak-Afrika en de toekomst van het christendom," Wereld en Zending, 24 ste Jaargang, 2, 27-39.

Dutch translation and extract of "Cry Jesus!" (1993).

Christianity in Africa: The Renewal of a Non-Western Religion (Edinburgh/New York: Edinburgh University Press/Orbis Books, 1995, reprinted 1997).

[Duff lectures, Edinburgh, 1989-1992]

1996

"How is Jesus Christ Lord?-Aspects of an Evangelical Christian Apologetics in the context of African religious pluralism' Exchange 25:1, 27-42. 
"Proclaiming Christ today—as an African and Evangelical Christian" in Proclaiming Christ Today, Huibert van Beek \& George Lemopoulos, eds. (Orthodox-Evangelical Consultation, Alexandria, 10-15 July 1995). Geneva: WCC / Bialystok, Poland: Syndesmos, 30-43.

"Five theses on the significance of modern African Christianity: A Manifesto,"

Transformation 13:1 (Jan/Mar 1996), 20-29. An expanded version of the article published in Studies in World Christianity, (The Edinburgh Review of Theology and Religion) 1:1 (1995): 51-67.

"Understanding African theology in the $20^{\text {th }}$ century" Bulletin for Contextual Theology in Southern Africa and Africa 3:2 (June 1996), 1-11.

"Theological Reflections," in Serving with the Poor in Africa, Yamamori et. al., eds. Monvoria: MARC, 181-192.

"Types of African Theology" in Christianity in Africa in the 1990s, C. Fyfe and A. Walls, eds. Edinburgh: University of Edinburgh, Centre for African Studies, 56-69.

1997

"What is the Gospel?" Transformation 14:1, Jan/March 1997, 1-4. (originally presented as part of the Asempa Jubilee Lectures, 27-29 September 1995 in Accra, Ghana.) See earlier 1995 "What is the Gospel?" ATF Bulletin 1, 6-7.

"African Theology," in The Modern Theologians (second edition), David Ford, ed. Oxford: Basil Blackwell, 426-44.

"Curriculum development: acquiring the right tools for the context" ATF Bulletin 5 (1997): 6-7.

Book Review: "The Christian Churches and the Democratisation of Africa" by Paul Gifford in African Affairs, July 1997, Vol.96 No. 384, 468-9.

"Religion and National Identity- Assessing the discussion from Cicero to Danquah Law and religion - inaugural lecture, June 25, 1997"

Ghana Academy of Arts and Sciences, 2006, 1-18.

"The Gospel and the transformation of the non-western world" in Anglican Life and Witness: a reader for the Lambeth Conference of Anglican bishops 1998, Vinay Samuel and Chris Sugden, eds. London: SPCK, 1997, 169-180. (same as Christianity in Africa, ch. 10) 
1998

"Facing the Challenge: Africa in World Christianity in the $21^{\text {st }}$ century-A vision of the African Christian future," JACT 1:1, 52-57. From paper given at ACMC in September 1997; adapted from "What is the Gospel?" 1995/1997.

"The Doctrine of Christ and the Significance of Vernacular Terminology" International Bulletin of Missionary Research 22:3 (July): 110-111. First appeared in the January-July 1998 issue of Akrofi-Christaller Centre News, and later as Chapter 6: One Song in Many Tongues, paper for graduate seminar, Edinburgh, 1997, in Jesus and the Gospel in Africa.

"The church in the African state: some biblical reflections" JACT 1:2, 58-60.

"Clement Anderson Akrofi," "Ephraim Amu," "Johannes Christaller," and "William Ofori-Atta" Biographical Dictionary of Christian Missions, G.H. Anderson, ed. New York: Macmillian; 9; 17; 133-134; 504-505.

1999

Jezus in de cultuur en geschiedenis van Afrika. Kampen: Uitgeverij Kok Kampen.

“Gospel and culture: Guest Editorial." JACT 2:2, 1.

"Gospel and culture: some insights for our time from the experience of the earliest Christians." JACT 2:2, 8-17.

"Translatability and the cultural incarnations of the faith" in New directions in mission and evangelization 3: faith and culture. From Chapter 7 in Christianity in Africa, 109-123.

2000

Jesus in Africa: The Christian Gospel in African History and Experience Oxford: Regnum Africa.

"A half century of African Christian thought: pointers to theology and theological education in the next half century." JACT, 3:1, 5-11.

"African Christian thought," "John Mbiti" in the Oxford Companion to Christian Thought, eds. A. Hastings, A. Mason, Oxford: Oxford University Press, 8-10, 418.

"Africa and Christianity on the threshold of the third millennium: the religious dimension." African Affairs 99, 303-323. 


\section{1}

"Scripture as the hermeneutics of culture and tradition." JACT 4:1; 2-11. Lectures given 9-13 August 1999.

"The African renaissance and theological reconstruction: the challenge of the twenty-first century" JACT 4:2, 29-33. Paper from conference 9-15 September 2001.

The Disciplines of the Spiritual Life and the Dynamics of Pastoral Ministry: A Handbook for Ministers Akopong-Akuapem: Akrofi-Christaller Memorial Centre.

Kamfo Awurade: A Compilation of Ghanaian Choruses \& Popular Hymns in English Kwame Bediako, ed. Akropong-Akuapem: Akrofi-Christaller Memorial Centre.

\section{2}

“Guest Editorial” JACT 5.1, 1-3.

“Editorial” JACT 5.2, 1-2.

"Toward a New Theodicy: Africa's Suffering in Redemptive Perspective" JACT 5.2, 47-52. $3^{\text {rd }}$ Payton lecture. Fuller Theological Seminary, Pasadena, CA, USA, October 2000

\section{3}

"African Theology as a Challenge to Western Theology" in Christian Identity in Cross-Cultural Perspective Martien E. Brinkman and Dirk van Keulen, eds. Meinema, Zoetermeer, 52-67.

"Biblical Exegesis in the African Context: The Factor and Impact of Translated Scriptures" JACT 6.1, 15-23.

"Festivals" ATF Bulletin 15, 5-7.

"The Church and the University: Some Reflections on the rationale for a Christian participation in the public education in Africa" ATF Bulletin 16, 5-7.

\section{4}

"Africa and Christian identity: recovering an ancient story"

Princeton Seminary Bulletin, ns 25 no 2, 153-161. 
“"Ethiopia shall soon stretch out her hands to God' (Ps. 68:31) African Christians living the faith: A turning point in Christian History" in A new day dawning: African Christians living the gospel: Essays in Honour of Dr. J.J. (Hans) Visser, (eds.) Kwame Bediako, Mechteld Jansen, Jan van Butselaar, and Aart Verburg. Zoetermeer: Boekencentrum, 2004, 30-40.

Religion, Culture and Language: An Appreciation of the Intellectual Legacy of Dr. J.B. Danquah. (J.B. Danquah Memorial Lectures, Series 37, 2004, 2-4 February 2004. Accra: Ghana Academy of Arts and Sciences, 2006.

"Christianity, Islam, and the Kingdom of God: Rethinking their Relationship from an African Perspective" JACT 7.2, 3-7.

Review Essay: Old Testament Research for Africa: A Critical Analysis and Annotated Bibliography of African Old Testament Dissertations, 1967- 2000, by Knut Holter in International Bulletin of Missionary Research 28 no 3 (July), 138.

\section{5}

"Christian Witness in the Public Sphere: Some Lessons and Residual Challenges from the Recent Political History of Ghana" in The Changing Face of Christianity: Africa, the West, and the World, eds. Lamin Sanneh and Joel A. Carpenter. New York: Oxford University Press, 2005, 117-132.

“Guest Editorial: Lived Christology” JACT 8.1, 1-2.

"Worship as vital participation- some personal reflections on ministry in the African church" JACT 8.2, 3-7.

"Ebenezer, this is how far the Lord has helped us": Reflections on the Institutional Itinerary of the Akrofi-Christaller Memorial Centre for Mission Research \& Applied Theology (1974-2005), May 2005, Kwame and Mary Bediako. 31 pages. Unpublished.

\section{6}

"Scripture as the Interpreter of Culture and Tradition" in Africa Bible Commentary, ed. Tokunboh Adeyemo. Grand Rapids, MI: Zondervan, 3-4.

"A New Era in Christian History-African Christianity as Representative Christianity: Some Implications for Theological Education and Scholarship" JACT 9.1, 3-12. 
“'Whose Religion is Christianity?': Reflections on Opportunities and Challenges for Christian Theological Scholarship as Public Discourse-The African Dimension" JACT 9.2, 43-48.

2007

“"Their past is also our present.' Why all Christians have need of ancestors: Making a case for Africa" AICMAR Bulletin 6, 1-16.

“"Missionaries did not bring Christ to Africa—Christ brought them.': Why Africa needs Jesus Christ" AICMAR Bulletin 6, 17-31.

"'In the Bible...Africa walks on familiar ground.': Why the World needs Africa" AICMAR Bulletin 6, 32-50.

"Bible Studies on Slavery and Freedom" with Gillian Bediako JACT 10.1, 3-8.

"The emergence of world Christianity and the remaking of theology" Nagel Institute Public Lecture at Calvin College, 19 July 2007. Later published in JACT 12.2 (2009).

\section{8}

"Thoughts on the nature of the project" JACT 11.2, 3-4.

"Why has the summer ended and we are not saved?" JACT 11.2 5-8

“"Whose religion is Christianity?': reflections on opportunities and challenges in Christian theological scholarship: the African dimension" in Mission in the twenty-first century, 107-117, 210-213. London: Darton, Longman and Todd; Maryknoll, NY: Orbis, 2008. Same as: JACT 9.22006

"Foreword" in John Azumah, My Neighbour's Faith: Islam explained for African Christians (Grand Rapids: Zondervan), ix-xi.

2009

"The emergence of world Christianity and the remaking of theology" JACT 12.2, 50-55.

\section{0}

"Christian faith and African Culture-An Exposition of the Epistle to the Hebrews" JACT 13.1, 45-57.

"Biblical exegesis in Africa: the significance of the translated Scriptures" in African theology on the way: Current Conversations, 12-20. 
2011

"Andrew F. Walls as Mentor," Understanding World Christianity: The Vision and Work of Andrew F. Walls eds. William R. Burrows, Mark R. Gornik, and Janice A. McLean, Orbis 7-10.

"Conclusion: The Emergence of World Christianity and the Remaking of Theology," Understanding World Christianity: The Vision and Work of Andrew F. Walls eds. William R. Burrows, Mark R. Gornik, and Janice A. McLean, Orbis, 243-256. 


\section{BIBLIOGRAPHY}

Aboagye-Mensah, Robert. "Socio-Political Thinking of Karl Barth: Trinitarian and Incarnational Christology as the Ground for his Social Action and its implications for us today." PhD dissertation, University of Aberdeen, 1984.

Adams, Frank Kwesi. Odwira and the Gospel: A Study of the Asante Odwira Festival and Its Significance for Christianity in Ghana. Oxford: Regnum, 2010.

Agyarko, Robert Owusu. "God's Unique Priest (Nyamesofopreko): Christology in the Akan Context." PhD dissertation. University of the Western Cape, 2009.

Aimé Césaire, une voix pour l'histoire directed by Euzhan Palcy. JMJ Productions: Martinique, 2006 [1994].

Anderson, Gerald, and Thomas Stransky, eds. Mission Trends No.3: Third World Theologies. Grand Rapids: Eerdmans, 1976.

Asamoah-Gyadu, J. Kwabena. African Charismatics: Current Developments within Independent Pentecostalism in Ghana. Leiden: Brill, 2005.

Asamoah-Gyadu, J. Kwabena. Contemporary Pentecostal Christianity: Interpretations from an African Context. Oxford: Regnum, 2013.

Asamoah-Gyadu, Kwabena. "“Who do you say that I am?: Revisiting Kwame Bediako's responses to an eternal Christological question.” Kwame Bediako Memorial Lecture, July 7, 2009, British Council Hall, Accra, Ghana.

Ashcroft, Bill, Gareth Griffiths, and Helen Tiffin. The Empire Writes Back: Theory and Practice In Post-colonial Literature. London: Routledge, 1989.

Baëta, C.G. Christianity and African Culture. Accra: Christian Council of the Gold Coast, 1955.

Baëta, C.G. Christianity in Tropical Africa. Oxford: Oxford University Press, 1968.

Balthasar, Hans Urs von. The Theology of Karl Barth: Exposition and Interpretation. Edward T. Oakes, trans. San Francisco: Ignatius, 1992.

Barrett, David. “AD 2000: 350 Million Christians in Africa," International Reyiew of Mission 59:233 (January 1970): 39-54.

Barth, Karl. “An Prof. Dr. Jean Daniélou S.J., Paris, 1948,” in Offene Briefe 1945-1968 (GA V.15), edited by Diether Koch. Zürich: Theologischer Verlag Zürich, 1984. 
Barth, Karl. “A Theological Dialogue” Theology Today 19/2 (July 1962).

Barth, Karl. Der Römerbrief, $1^{\text {st }}$ ed. Bern: G. A. Bäschlin, 1919.

Barth, Karl. "Extra Nos-Pro Nobis-In Nobis" in Hören und Handlen, Festschrift für Ernst Wolf zun 60. Geburtstag, ed. Helmut Gollwitzer und Hellmut Traub. Munich: Chr. Kaiser, 1962.

Barth, Karl. "Introduction Essay" in Ludwig Feuerbach, Essence of Christianity. New York: Harper \& Row, 1957.

Barth, Karl. "No Boring Theology!: A Letter from Karl Barth" South East Asian Journal of Theology 11 (Autumn 1969).

Barth, Karl. "Afterword" in Christoph Blumhardt, Action in Waiting. Rifton, NY: Plough Publishing House, 2012.

Barth, Karl. Das Evangelium in der Gegenwart. München: Chr. Kaiser, 1935.

Barth, Karl. Epistle to the Romans, $2^{\text {nd }}$ edition. Edwyn C. Hoskyns trans. London: Oxford University Press, 1968 [1933].

Barth, Karl. Evangelical Theology: An Introduction. Grand Rapids: Eerdmans, 1963.

Barth, Karl. Falkultätsalbum der Evangelisch-theologischen Fakultät. Münster, 1927.

Barth, Karl. Fragments Grave and Gay. London: Fontana, 1971.

Barth, Karl. Göttingen Dogmatics, vol. 1. Geoffrey W. Bromiley trans. Grand Rapids: Eerdmans, 1991, [1924].

Barth, Karl. How I Changed My Mind. Richmond, VA: John Knox Press, 1966.

Barth, Karl. Humanity of God. Louisville: Westminster John Knox Press, 1960.

Barth, Karl. Karl Barth's Table Talk, recorded and edited by John Godsey. Richmond, VA: John Knox Press, 1963.

Barth, Karl. Learning Jesus Christ through the Heidelberg Catechism. Translated from Die christliche Lehre nach dem Heidelberger Katechismus (Zollikon-Zürich: Evangelisher Verlag A.G., 1948) by Shirley Guthrie. Grand Rapids: Eerdmans, 1964.

Barth, Karl. The Christian Life: Church Dogmatics IV.4, Lecture Fragments. Hans-Anton Drewes and Eberhard Jüngel, eds. Geoffrey Bromiley, trans. London: T\&T Clark, 2004. 
Barth, Karl. Theology and Church: Shorter Writings 1920-1928. London: SCM Press, 1962.

Barth, Karl. Theology of Schleiermacher. Grand Rapids: Eerdmans, 1982.

Barth, Karl. Wolfgang Amadeus Mozart. Grand Rapids: Eerdmans, 1986.

Barth, Karl. The Word of God and Theology, trans. Amy Marga. New York: T\&T Clark, 2011.

Bediako, Gillian Mary. Primal Religion and the Bible: William Robertson Smith and His Heritage. London: Bloomsbury Academic, 1997.

Bediako, Kwame. "An Evaluation of the Achievement of the Christian Ideal in Education in Ghana from the 19th century to the early 20th century," in Educating a NationA Christian perspective for our time the Andrew McCutcheon Atkinson Memorial Lectures delivered at the Presbyterian Church of the Resurrection, Accra, Ghana, 1 December 1993, unpublished.

Bediako, Kwame. "A New Era in Christian History-African Christianity as Representative Christianity: Some Implications for Theological Education and Scholarship" JACT 9.1 (2006).

Bediako, Kwame. "Africa and Christianity on the threshold of the third millennium: the religious dimension.” African Affairs 99 (2000).

Bediako, Kwame. "Biblical Exegesis in the African Context: The Factor and Impact of Translated Scriptures" JACT 6.1 (2003).

Bediako, Kwame. "Challenges of Ghana's Fourth Republic: A Christian Perspective" The William Ofori-Atta Memorial Lectures, 7th-9th October 1992.

Bediako, Kwame. "Christ in Africa: Some Reflections on the Contribution of Christianity to the African Becoming" African Futures.

Bediako, Kwame. "Christian Faith and African Culture-An Exposition of the Epistle to the Hebrews," JACT 13:1 (June 2010).

Bediako, Kwame. Christianity in Africa: The Renewal of a Non-Western Religion. Edinburgh: Edinburgh University Press, 1995.

Bediako, Kwame. "Culture," in New Dictionary of Theology. Sinclair Ferguson and David Wright, eds. Downers Grove, IL: InterVarsity Press, 1988.

Bediako, Kwame. "Death and the gospel in the Ghanaian context" Exchange 20:2 (1991). 
Bediako, Kwame. "Gospel and culture: Guest Editorial.” JACT 2:2 (1999).

Bediako, Kwame. "Gospel and culture: some insights for our time from the experience of the earliest Christians." JACT 2:2 (1988).

Bediako, Kwame. “'In the Bible...Africa walks on familiar ground.': Why the World needs Africa" AICMAR Bulletin 6 (2007).

Bediako, Kwame. "Islam and the Kingdom of God," Stone Lecture \#3, Princeton Theological Seminary, Princeton, NJ, October 21, 2003.

Bediako, Kwame. Jesus and the Gospel in Africa. Oxford: Regnum, 2000.

Bediako, Kwame. "Jesus in African Culture: A Ghanaian perspective," in Jesus and the Gospel in Africa. Oxford: Regnum, 2000.

Bediako, Kwame. L'Univers Interior de Tchicaya U Tam 'si, T.E.R., Bordeaux III, July 1973. Unpublished Doctoral Thesis, 213 pages.

Bediako, Kwame. "Memorandum to Christian Service College Council on the work of the College," 29 May 1978, unpublished.

Bediako, Kwame. Négritude et Surréalisme: Essai sur l'oeuvre poétique de Tchicaya U Tam 'si. T.E.R., Bordeaux III, October 1970. Unpublished M.A. Thesis, 163 pages.

Bediako, Kwame. "New paradigms on ecumenical co-operation: An African perspective" International Review of Mission (July 1992).

Bediako, Kwame. "Recognizing the Primal Religions," Stone Lecture \#2, Princeton Theological Seminary, Princeton, NJ, October 21, 2003.

Bediako, Kwame. "[Response to] David Hesselgrave: dialogue on contextualization continuum." Gospel in Context 2:3 (1979).

Bediako, Kwame. "Response to Taber: Is there more than one way to do theology?" Gospel in Context 1:1 (1978).

Bediako, "Reading Signs of the Kingdom," Stone Lecture \#1, Princeton Theological Seminary, Princeton, NJ, October 20, 2003.

Bediako, "Religion and National Identity- Assessing the discussion from Cicero to Danquah lecture, June 25, 1997." Ghana Academy of Arts and Sciences, 2006.

Bediako, Kwame. "Review of African theology en route" Journal of Religion in Africa 11:2 (1980). 
Bediako, Kwame. "Scripture as the hermeneutics of culture and tradition" JACT 4:1 (2001).

Bediako, Kwame. "The Doctrine of Christ and the Significance of Vernacular Terminology" International Bulletin of Missionary Research 22:3 (July 1998).

Bediako, Kwame. "The emergence of world Christianity and the remaking of theology" JACT 12.2 (2009).

Bediako, Kwame. "The Holy Spirit, the Christian Gospel and religious change: the African evidence for a Christian theology of religious pluralism," in Essays in Religious Studies for Andrew Walls, ed. James Thrower. Aberdeen: Department of Religious Studies, University of Aberdeen, 1986.

Bediako, Kwame. "The relevance of a Christian approach to culture in Africa," in Christian education in the African Context. Proceedings of the first Africa regional conference of the International Association for the Promotion of Christian Higher EducationIAPCHE, 4-9 March 1991, 24-35. Harare, Zimbabwe, Grand Rapids: IAPCHE.

Bediako, Kwame. "“Their past is also our present.' Why all Christians have need of ancestors: Making a case for Africa" AICMAR Bulletin 6 (2007): 9.

Bediako, Kwame. Theology and Identity: the impact of culture on Christian thought in the second century and modern Africa. Oxford: Regnum, 1992.

Bediako, Kwame. "The significance of modern African Christianity—A Manifesto," Studies in World Christianity (The Edinburgh Review of Theology and Religion) 1:1 (1995).

Bediako, Kwame. "The Willowbank Consultation, January 1978 - a personal reflection," Themelios 5:2 (January 1980).

Bediako, Kwame. "Thoughts on the nature of the project" JACT 11.2 (2008).

Bediako, Kwame. "Types of African Theology" in Christianity in Africa in the 1990s, eds. C. Fyfe and A. Walls. Edinburgh: University of Edinburgh, Centre for African Studies.

Bediako, Kwame. “'Whose Religion is Christianity?': Reflections on Opportunities and Challenges for Christian Theological Scholarship as Public Discourse-The African Dimension" JACT 9.2 (2006).

Bediako, Kwame. "Worship as vital participation- some personal reflections on ministry in the African church" JACT 8.2 (2005).

Beier, Ulli. Introduction to African Literature. Evanston: Northwestern University Press, 1970. 
Bennett, Louise. Selected Poems. Kingston, Jamaica: Sangster's Book Stores, 1982.

Berger, Peter L. The Sacred Canopy: Elements of a Sociological Theory of Religion. New York: Anchor Books, 1990.

Berger, Peter L. The Heretical Imperative: Contemporary Possibilities of Religious Affirmation. Garden City, NY: Anchor Press, 1979.

Berkhof, Hendrik. "Barths Lichterlehre im Rahmen der heutigen Theologie, Kirche und Welt" in Karl Barths Lichterlehre. Zurich: Theologischer Verlag, 1977.

Berkouwer, C.G. The Triumph of Grace in the Theology of Karl Barth. London: Paternoster Press, 1956.

Bhabha, Homi. Location of Culture. London: Routledge, 1994.

Blumhardt, Christoph. Christoph Blumhardt and his message. R. Lejeune, ed. Rifton, New York: The Plough Publishing House, 1963.

Bonhoeffer, Dietrich. Barcelona, Berlin, New York: 1928-1931. Dietrich Bonhoeffer Works vol. 8. Minneapolis: Fortress Press, 2008.

Bonhoeffer, Dietrich. Letters and Papers from Prison. Dietrich Bonhoeffer Works vol. 10. Minneapolis: Fortress Press, 2010.

Bornkamm, Karin. Christus—König und Priester: Das Amt Christi bei Luther im Verhältnis zur Vor- und Nachgeschichte. Tübingen: Mohr Siebeck, 1998.

Bosch, David. "God through African Eyes" in Relevant Theology for Africa, ed. H.J. Becken. Durban: Lutheran Publishing House.

Brathwaite, Kamau. "History of the Voice," in Roots: Essays in Caribbean Literature. Ann Arbor: U of Michigan Press, 1993.

Burrows, William R., Mark R. Gornik, and Janice A. McLean, eds. Understanding World Christianity: The Vision and Work of Andrew F. Walls. Maryknoll, NY: Orbis, 2011.

Busch, Eberhard. Karl Barth: His life from letters and autobiographical texts. Philadelphia: Fortress, 1976.

Busch, Eberhard. Karl Barths Lebenslauf: Nach Seinen Briefen U. Autobiograph. Texten. München: Kaiser, 1975. 
Busch, Eberhard. The Great Passion: An Introduction to Karl Barth's Theology. Grand Rapids: Eerdmans, 2004.

“Call to Glory,” Funeral program for Kwame Bediako, July 2008.

Calvin, John. Institutes of the Christian Religion. Trans. Ford Lewis Battles. Philadelphia: Westminster John Knox, 1960.

Carson, D.A. Gagging of God: Christianity Confronts Pluralism. Grand Rapids: Zondervan, 1996.

Carter, J. Kameron. Race: A Theological Account. New York: Oxford University Press, 2008.

Césaire, Aimé. Discourse On Colonialism. New York: MR, 1972 [1950].

Césaire, Aimé. Notebook of a Return to My Native Land: Cahier D’un Retour Au Pays Natal, trans. Mireille Rosello and Annie Pritchard (Newcastle upon Tyne, England: Césaire, Aimé. Bloodaxe Books, 1995.

Césaire, Aimé. Notebook of a Return to the Native Land, trans. and ed. Clayton Eshleman and Annette Smith. Middletown, CT: Wesleyan University Press, 2001.

Chestnutt, Glenn A. Challenging the Stereotype: the Theology of Karl Barth as a Resource for Inter-religious Encounter In a European Context. Oxford: Peter Lang, 2010.

Christ Presbyterian Church, Akropong-Akuapem, Ghana website, "History," http://www.akropongcpc.faithweb.com/history.htm, accessed January 31, 2014.

Christaller, J. G. A Dictionary of the Asante and Fante Language Called Tshi (chwee, Twi i): with a Grammatical Introduction and Appendices On the Geography of the Gold Coast and Other Subjects. Basel: printed for the Evangelical Missionary Society, 1881.

Christaller, J. G. A Grammar of the Asante and Fante Language Called Tshi Based On the Akuapem Dialect with Reference to the Other (akan and Fante) Dialects. Basel: Evang. missionary soc., 1875.

Christensen, Torben, and William R. Hutchinson, eds. Missionary ldeologies in the lmperialist Era: 1880-1920. Copenhagen: Aros, 1982.

Collins Winn, Christian. Jesus Is Victor!: The Significance of the Blumhardts for the Theology of Karl Barth. Eugene, OR: Princeton Theological Monograph SeriesPickwick Publications, 2009. 
Danquah, J.B. The Akan Doctrine of God: A Fragment of Gold Coast Ethics and Religion. New York: Routledge, 2006 reprint of second edition, 1968 [1944].

DeCou, Jessica. "Relocating Barth's Theology of Culture: Beyond the 'True Words' Approach of Church Dogmatics IV/3" International Journal of Systematic Theology 15:2 (April 2013).

Dempsey, Michael T. ed. Trinity and Election in Contemporary Theology. Grand Rapids: Eerdmans, 2011.

Dodd, C.H. The Parables of the Kingdom. New York: Scribner, 1961 [1935].

Dorrien, Gary J. Kantian Reason and Hegelian Spirit: The Idealistic Logic of Modern Theology. Oxford: Wiley-Blackwell, 2012.

Éla, Jean-Marc. My Faith as an African, trans. by John Pairman Brown and Susan Perry. Maryknoll, NY: Orbis, 1988.

Ephirim-Donkor, Anthony. African Religion Defined: A Systematic Study of Ancestor Worship among the Akan. New York: University Press of America, 2010.

Ephirim-Donkor, Anthony. African Spirituality: On Becoming Ancestors (Trenton, NJ: Africa World Press, 1997)

Fanon, Frantz. Black Skin, White Masks. New York: Grove Press, 2008 [1952].

Fanon, Frantz. The Wretched of the Earth. New York: Grove Press, 2004 [1961].

Fasholé-Luke, Edward. "Ancestor veneration and the communion of saints" in New Testament Christianity for Africa and the World. Mark Glasswell and Edward Fasholé-Luke, eds. London: SPCK, 1974.

Feuerbach, Ludwig. Essence of Christianity. George Eliot, trans. Introduction by Karl Barth. Foreword by H. Richard Niebuhr. New York: Harper \& Row, 1957.

Flett, John. The Witness of God: The Trinity, Missio Dei, Karl Barth, and the Nature of Christian Community. Grand Rapids: Eerdmans, 2010.

Fotland, Roar. "Ancestor Christology in Context: Theological Perspectives of Kwame Bediako," PhD dissertation. Bergen: University of Bergen, 2005.

Frei, Hans. "The Doctrine of Revelation in the Thought of Karl Barth, 1909 to 1922: The Nature of Barth's Break with Liberalism." PhD diss., Yale University, 1956.

Fulkerson, Mary McClintock. Places of Redemption: Theology for a Worldly Church. Oxford: Oxford University Press, 2007. 
Gitari, David, and Patrick Benson, eds. Witnessing to the Living God in contemporary Africa. Nairobi: Uzima Press, 1986.

Glasse, John. "Barth on Feuerbach," The Harvard Theological Review 57:2 (April 1964).

Gornik, Mark. Word Made Global: Stories of African Christianity in New York City. Grand Rapids: Eerdmans, 2011.

Gorringe, Timothy. Karl Barth: Against Hegemony. New York: Oxford University Press, 1999.

Graham, Billy. The Jesus Generation. London: Hodder and Stoughton, 1972.

Green, Clifford J. Karl Barth: Theologian of Freedom. San Francisco, CA: Collins, 1989.

Green, Garrett. Karl Barth On Religion: The Revelation of God as the Sublimation of Religion. London: T\&T Clark, 2007.

Greggs, Tom. "'Jesus is victor': passing the impasse of Barth on universalism” Scottish Journal of Theology 60:2 (May 2007), 196-212.

Greggs, Tom. Theology Against Religion: Constructive Dialogues with Bonhoeffer and Barth. New York: Continuum, 2011.

Gunton, Colin E. The Barth Lectures, ed. Paul Brazier. New York: T\&T Clark, 2007.

Gussman, Wilhelm. Quellen und Forschungen zur Geschichte des Augsburgischen Glaubensbekenntnisses. Leipzig and Berlin: B.G. Teubner, 1911.

Gutiérrez, Gustavo. We Drink From Our Own Wells. Maryknoll, NY: Orbis, 1984.

Gyeke, Kwame. Essay on African Philosophical Thought: the Akan Conceptual Scheme. Cambridge: Cambridge University Press, 1987.

Habets, Myk, and Phillip Tolliday, eds. Trinitarian Theology after Barth. Eugene, OR: Princeton Theological Monograph series, Pickwick Publications, 2011.

Harnack, Adolf. What is Christianity? trans. Thomas Bailey Saunders. New York: Harper \& Brothers, 1957 [1900].

Hartman, Tim. "Lost in Translation: Postcolonial Reflections on 'The Panare killed Jesus Christ"” Cross Currents 63:3 (September 2013): 328-349.

Hastings, Adrian. “A New Voice out of Ghana: A Review of Kwame Bediako's Christianity in Africa" The Church Times (January 1996). 
Hector, Kevin. Theology Without Metaphysics: God, Language, and the Spirit of Recognition. Cambridge: Cambridge University Press, 2011.

Hengel, Martin, and Anna Maria Schwemer, eds. Der messianische Anspruch Jesu und die Anfange der Christologie. Tübingen: Mohr Siebeck, 2001.

Higton, Mike, and John C. McDowell, eds. Conversing with Barth. Burlington, VT: Ashgate, 2004.

Hübinger, Gangolf. Kulturprotestantismus und Politik: Zum Verhältnis von Liberalismus und Protestantismus im Wilhelminischen Deutschland. Tübingen: J.C.B. Mohr, 1994.

Hunsinger, George. Disruptive Grace: Studies in the Theology of Karl Barth. Grand Rapids: Eerdmans, 2000.

Hunsinger, George. How to Read Karl Barth. New York: Oxford University Press, 1991.

Idowu, Bolaji. African Traditional Religion: a Definition. Maryknoll, NY: Orbis Books, 1973.

Idowu, Bolaji. Towards an Indigenous Church. London: Oxford University Press, 1965.

Jansen, John Frederick. Calvin's Doctrine of the Work of Christ. London: J. Clark, 1956.

Jenkins, Philip. The New Faces of Christianity: Believing the Bible In the Global South. New York: Oxford University Press, 2006.

Jenkins, Philip. The Next Christendom: The Rise of Global Christianity. New York: Oxford University Press, 2002.

Johnson, Adam J. "The Servant Lord: A Word of Caution Regarding the munus triplex in Karl Barth's Theology and the Church today" Scottish Journal of Theology 65:2 (2012).

Johnson, William Stacy. The Mystery of God: Karl Barth and the Postmodern Foundations of Theology. Louisville: Westminster John Knox, 1997.

Jones, Paul Dafydd. The Humanity of Christ: Christology in Karl Barth's Church Dogmatics. New York: T\&T Clark, 2008.

Jüngel, Eberhard, ed. Zeitschrift für Theologie und Kirche. Tübingen: Mohr Siebeck, 1986.

Jüngel, Eberhard. Karl Barth: A Theological Legacy, trans. by Garrett E. Paul. Philadelphia: The Westminster Press, 1986. 
Knipp, Thomas R. "Negritude and Negation: The Poetry of Tchikaya U'Tamsi” Books Abroad 48:3 (Summer, 1974).

Kraus, Hans-Joachim. "Logos und Sophia: Biblisch-theologishe Grundlegung und Konkretisierung zum Thema 'Das Licht und die Lichter" in Karl Barths Lichterlehre. Zurich: Theologischer Verlag, 1977.

Kutter, Hermann. They Must: Or, God and the Social Democracy. A Frank Word to Christian Men and Women. American ed. Chicago: Co-operative Printing Co, 1908.

Laansma, Jon, and Daniel J Treier. Christology, Hermeneutics, and Hebrews: Profiles From the History of Interpretation. London: T \& T Clark, 2012.

Lindsay, Mark R. Barth, Israel, and Jesus: Karl Barth's Theology of Israel. Barth Studies Series; Aldershot: Ashgate, 2007.

Lindsay, Mark R. Reading Auschwitz with Barth: The Holocaust as Problem and Promise for Barthian Theology. Eugene, OR: Pickwick, 2014.

Maluleke, Tinyiko Sam. "African Traditional Religions in Christian Mission and Christian Scholarship: Re-Opening a Debate that Never Started," Religion \& Theology 5:2 (1998).

Maluleke, Tinyiko Sam. "Black and African Theologies in the New World Order: A Time to Drink from our Own Wells," Journal of Theology for Southern Africa 96 (November 1996).

Marquardt, Friedrich-Wilhelm. Theologie und Sozialismus: Das Beispiel Karl Barths. $3^{\text {rd }}$ edition. Münich: Chr. Kaiser, 1972.

Marsh, Charles. Reclaiming Dietrich Bonhoeffer: The Promise of his Theology. New York: Oxford University Press, 1994.

Mbiti, John. Introduction to African Religion, second edition. Oxford: Heinemann, 1991 [1975].

Mbiti, John. "Some Reflections on African Experience of Salvation Today" in Living Faith and Ultimate Goals, ed. S.J. Samartha. Geneva: World Council of Churches, 1974.

Mbiti, John. "Theological impotence and the universality of the Church" Mission Trends No.3: Third World Theologies. Gerald Anderson and Thomas Stransky, eds. Grand Rapids: Eerdmans, 1976.

Mbiti, John. Bible and Theology in African Christianity. Nairobi: Oxford University Press, 1986. 
McCormack, Bruce L. “The Significance of Karl Barth's Theological Exegesis of Philippians" in Karl Barth, The Epistle to the Philippians: $40^{\text {th }}$ Anniversary Edition. Louisville: Westminster John Knox Press, 2002.

McCormack, Bruce L. "The Identity of the Son: Karl Barth's Exegesis of Hebrews 1.1-4 (and similar passages)" in Christology, Hermeneutics, and Hebrews: Profiles from the History of Interpretation. London: T\&T Clark, 2012.

McCormack, Bruce L. Karl Barth's Critically Realistic Dialectical Theology: Its Genesis and Development 1909-1936. Oxford: Clarendon Press, 1995.

McCormack, Bruce L. Orthodox and Modern: Studies in the Theology of Karl Barth. Grand Rapids, MI: Baker Academic, 2008.

McCulloh, Gerald W. Christ's Person and Life-Work in the Theology of Albrecht Ritschl with Special Attention to Munus Triplex. Landham, MD: University Press of America, 1990.

Metzger, Paul. The Word of Christ and the World of Culture: Sacred and Secular through the Theology of Karl Barth. Grand Rapids: Eerdmans, 2003.

Moltmann, Jürgen. The Future of Creation: Collected essays. Minneapolis: Fortress, 1979.

Moore, Gerald. Twelve African Writers. London: Hutchinson University Library for Africa, 1980.

Moore, Gerald. "The Politics of Négritude" in Protest and Conflict in African Literature. Cosmo Pieterse \& Donald Munro, eds. London: Heinemann, 1969.

Mottu, Henry. "La Lumière et les Lumières. Christ et le monde selon le dernier Barth, 1988" in Un Itinéraire Théologique: Barth, Bonhoeffer et la Théologie AfricaineAméricane. Genève: Cahiers de la Revue de Théologie et de Philosophie 21, 2004.

Neder, Adam. Participation in Christ: An Entry Into Karl Barth's Church Dogmatics. Louisville: Westminster John Knox, 2009.

Nichols, Bruce, ed. The Unique Christ in our pluralist world. Grand Rapids: Baker, 1994.

Nyamiti, Charles. Christ As Our Ancestor: Christology From an African Perspective. Gweru, Zimbabwe: Mambo Press, 1984.

O'Collins, Gerald, and Mary Ann Meyers, eds. Light from Light: Scientists and Theologians in Dialogue. Grand Rapids: Eerdmans, 2012. 
Okorocha, Cyril. "The Meaning of Salvation: An African Perspective" in Emerging Voices in Global Christian Theology, ed. William Dyrness. Grand Rapids: Zondervan, 1994.

Olabimtan, Kehinde. “'Is Africa Incurably Religious?' II: A Response to Jan Platvoet \& Henk van Rinsum," Exchange 32:4 (2003).

Olupona Jacob K. and Regina Gemignani, African Immigrant Religions In America. New York: New York University Press, 2007.

Oosthuizen, G.C. Post-Christianity in Africa: A Theological and Anthropological Study. London: C. Hurst \& Co., 1968.

Opoku, Kofi Asare. West African Traditional Religion. Coraville, IA: FEP International, 1978.

Opoku, Kofi Asare. "Post-colonial Church Cultures in Multicultural Societies," Transatlantic Roundtable on Religion and Race, Accra, Ghana, 31 July 2013.

Opoku, Kofi. "Toward a Holistic View of Salvation" in Healing for God's World: Remedies from Three continents (New York: Friendship Press, 1991), 41-60.

Ortiz, Fernando. Cuban Counterpoint: Tobacco and Sugar, trans. Harriet de Onís. New York: Knopf, 1947.

Palma, Robert J. Karl Barth's Theology of Culture: The Freedom of Culture for the Praise of God. Allison Park, PA: Pickwick, 1983.

p'Bitek, Okot. African Religions in Western Scholarship. Kampala: East African Literature Bureau, 1970.

Pannenberg, Wolfhart. Jesus: God and Man, tr. Lewis L. Wilkins and Duane A. Priebe. London: SCM, 1968.

Pannenberg, Wolfhart. Systematic Theology vol. 2, trans. Geoffrey Bromiley. Grand Rapids: Eerdmans, 1991.

Parrinder, Geoffrey. Religion in Africa. Harmondsworth: Penguin Books, 1969.

Peterson, Eugene H. The Message: The Bible in Contemporary Language. Colorado Springs, Colorado: NavPress, 2005.

Pfleiderer, Georg. "Das 'prophetische Amt' der Theologie: Zur systematischen Rekonstruktion der Theologie Karl Barths und ihres Entwicklungsgangs," Zeitschrift Für Dialektische Theologie 17:2 (January 2001). 
Pieterse, Cosmo, and Donald Munro. Protest and Conflict in African Literature. London: Heinemann, 1969.

Platvoet, Jan, and Henk Rinsum. "Is Africa incurably religious?: Confessing and Contesting an invention" Exchange 32:2 (2003).

Plonz, Sabine. Die herrenlosen Gewalten: eine Relektüre Karl Barths in befreiungstheologischer Perspektive. Mainz: Matthias-Grünewald-Verlag, 1995.

Pobee, J.S. Religion in a Pluralistic Society. Brill: Leiden, 1976.

Pobee, John S. Toward an African Theology. Nashville: Abingdon, 1979.

Rah, Soong-Chan. The Next Evangelicalism: Freeing the Church from Western Cultural Captivity. Grand Rapids: InterVarsity Press, 2009.

Reardon, Bernard M. G. Liberal Protestantism. Stanford, CA: Stanford University Press, 1968.

Rein, Susan Erica. "Religiosity in the Poetry of Tchicaya U Tam'si" Journal of Religion in Africa 10:3 (1979).

Rivera, Mayra. The Touch of Transcendence: A Postcolonial Theology of God. Louisville: Westminster John Knox Press, 2007.

Ryan, Patrick. "'Arise, O God!" The Problem of 'Gods' in West Africa" Journal of Religion in Africa 11:3 (1980).

Samuel, Vinay, and Chris Sugden, eds. Sharing Jesus in the Two-Thirds World. Grand Rapids: Eerdmans, 1984.

Sanneh, Lamin. Translating the Message: The Missionary Impact on Culture. Maryknoll, NY: Orbis, 1989.

Sarpong, Peter. The Sacred Stools of the Akan. Accra-Tema: Ghana Pub. Corp., 1971.

Sawyerr, Harry. “Ancestor Worship I: The Mechanics” Sierra Leone Bulletin of Religion 6:2 (December 1964).

Schaaf, Ype. On their way rejoicing-The history and role of the Bible in Africa. Carlisle: Paternoster Press, 1995.

Smith, Noel. The Presbyterian Church of Ghana, 1835-1960: A Younger Church in a Changing Society. Accra: Ghana Universities Press, 1966. 
Sonderegger, Katherine. That Jesus Christ Was Born a Jew: Karl Barth's "doctrine of Israel.” University Park, PA: Pennsylvania State University Press, 1992.

Stam, Robert, and Ella Shohat, "Whence and Whither Postcolonial Theory?" New Literary History 43 (2012).

Stanley, Brian. The World Missionary Conference, Edinburgh 1910. Grand Rapids: Eerdmans, 2009.

Sturch, Richard. The Word and the Christ: An Essay in Analytic Christology. Clarendon Press: Oxford, 1991.

Tanner, Kathryn. Theories of Culture: A New Agenda for Theology. Minneapolis: Fortress Press, 1997.

Taylor, Charles. A Secular Age. Cambridge, Mass.: Belknap Press of Harvard University Press, 2007.

Taylor, John V. The Primal Vision: Christian Presence amid African Religion. Philadelphia: Fortress Press, 1963.

Taylor, John. "Rereading Tchicaya U Tam'si” The Antioch Review 66:4 (Fall 2008).

Tchicaya U Tam'si. Tchicaya U Tam 'si: Selected Poems. Gerald Moore, trans. London: Heinemann, 1970.

Thompson, Geoff. “'As open to the world as any theologian could be...'?: Karl Barth's Account of Extra-Ecclesial Truth and Its Value to Christianity's Encounter with Other Religious Traditions" PhD thesis, University of Cambridge, 1995.

Thompson, Geoff. "Religious Diversity, Christian Doctrine and Karl Barth," International Journal of Systematic Theology, 8:1 (January 2006).

Thrower, James, ed. Essays in Religious Studies for Andrew Walls. Aberdeen: Department of Religious Studies, University of Aberdeen, 1986.

Wainright, Geoffrey. For our salvation: two approaches to the work of Christ. Grand Rapids: Eerdmans, 1997.

Walls, Andrew F. "Kwame Bediako and Christian Scholarship in Africa." International Bulletin of Missionary Research 32:4 (2008).

Walls, Andrew F. The Missionary Movement in Christian History: Studies in the Transmission of Faith. Maryknoll, NY: Orbis, 1996.

Webster, John. Barth $2^{\text {nd }}$ edition. New York: Continuum, 2004. 
Webster, John. Barth's Moral Theology: Human Action in Barth's Thought. Grand Rapids: Eerdmans, 1998.

Welch, Claude. Protestant Thought in the Nineteenth Century, 2 vols. New Haven: Yale University Press, 1972.

Wiggermann, Karl-Friedrich. “'Ein eigentümlich beschatter Bereich’: Die Neuzeit in Karl Barths 'Lichterlehre”' Zeitschrift für Dialektische Theologie 25:2 (2009).

Williams, David T. The Office of Christ and its Expression in the Church: Prophet, Priest, King. Lewiston, NY: Edwin Mellen Press, 1997. 